FRANCI8CA LUIZA GIMENEZ CARDIERI

Encadernado com a colaboração

da Área de Pós-Graduação em

Geografia HUMANA

GESTÃO: junho/95-maio/97

\title{
O MUNICIPIO DE JANDIRA \\ NO CONJUNTO METROPOLITANO \\ DE SÃO PAULO
}

\author{
DISSERTAGÃo dE MESTRADO \\ APRESENTADA AO DEPARTAMENTO \\ DE GEOGRAFIA DA FACULDADE \\ DE FILOSOFIA, LETRAS E CIÊNCIAS \\ HUMANAS DA UNIVERSIDADE \\ DE SÁO PAULO
}

ORIENTACÁO: PROFESSOR DOUTOR MÁRIO DE BIASI 
A meus pais,

pela vida e incentivo perene.

A Josē Luis,

pela dedicação em todos os momentos.

A Fābio e Celso

pelo tempo não convivido. 


\section{AGRADECIMENTOS}

Este trabalho, em sua trajetōria, necessitou da ajū da, do apoio, do sacrifício, do silêncloe das críticas de um número imenso de pessoas. Agradecê-las nominalmente torna-se dificil. A todos que tornaram possivel sua realização um. obrigado, não apenas com palavras, pois estas se desvanecem no ato de pronunciá-las, porém, um obrigado sincero com muito ca rinho.

Ao professor orlentador, Dr. Mário De Biasi, por ter permitido sua concretizaçāo, meu reconhecimento.

A professora e amiga, Ana Maria Marangoni, pois seu apoio foi um incentivo.

Ao povo jandirense, pela particlpação efetiva.

$E$ às entidades e seus responsávels pela colaboração eficaz nas diversas etapas do trabalho. 


\section{INTRODUCCAO}

1. ETAPAS DE CRESCIMENTO URBANO

1.1. Jandira e sua histórı́ ....................... 9

1.2. Fatores de crescimento urbano .................. 18

1.3. Implantação de 1ndūstrias ................... 31

1.4. Loteamentos atuais ........................ 36

1.5. Planta dos loteamentos ..................... 42

2. o sitio e o uso uRbano do solo ..................... 46

2.1. Aspectos fIsdcos: localização e sItlo ........... 46

2.2. Uso do solo ............................. 53

2.3. Função urbana ............................ 60

2.4. Equipamentos urbanos ...................... 63

1. A populaçăo de jandira ....................... 86

3.1. Crescimento vegetativo ..................... 88

3.2. o papel đa migração ......................... 90

3.3. Motivos para fixação em Jandira ................ 107

3.4. Emigração ................................. 112

3.5. Composição por sexo, Idade e escolaridade ......... 116

3.6. Estrutura profissional da população ativa ........ 121 
Påg.

4. NIVEL DE VIDA ............................. 129

5. DESlocamentos espaciais da populaçÃo ............. 136

5.1. Fluxos: trabalho-residência .................. 136

5.2. Fluxos: comerclals ....................... 139

5.3. Fluxos: serviços ......................... 142

5.4. Fluxos: escolares e recreaçäo ................. 145

CONCLUSAO $\ldots \ldots \ldots \ldots \ldots \ldots \ldots \ldots \ldots \ldots \ldots \ldots \ldots \ldots \ldots \ldots \ldots \ldots \ldots \ldots$

BIBLIOGRAFIA $\ldots \ldots \ldots \ldots \ldots \ldots \ldots \ldots \ldots \ldots \ldots \ldots \ldots \ldots \ldots \ldots$ 
Os problemas da Região Metropolitana de são Paulo têm sido analisados por diversos autores, entre os quais Camargo e outros, que afirmam: "O vertiginoso crescimento demográfico da Região, que entre 1968-1970 fol de 5,58 ao ano, junto com o pro cesso de retenção dos terrenos à espera de valorização, levou ao surgimento de bairros cada vez mais distantes. Amontoam-se popu lações em āreas longínquas, afastadas dos locals de trabalho, 1m pondo-se distâncias de deslocamento cada vez malores. Acentua-se - processo de criação de "cidades-dormitório", verdadelros acampa mentos desprovidos de infra-estrutura. Neste contexto, além do trabalho e da moradia, os transportes passam a ser un dos proble mas cructais" (1).

A área periférica tem passado, nos últimos tempos, por um processo de adensamento populacional ocasionado "pela pro liferação dos serviços terciārios, provocando o acréscimo da popú lação empregada e a Ineficiêncla de alojamentos nos bairros da me trōpole, auxiliado ainda por outros fatores e, em decorrência, a procura de aluguéis mals baratos em áreas servidas por melos de cłrculação" (2).

o Plano Metropolitano de Desenvolvimento Integrado PMDI - ao analisar o Censo de 1970, mostrou o crescimento, espon tâneo e bastante acentuado, das sub-regiões Norte, Noroeste e Sudoeste da Grande São Paulo. No entanto, ressalta que a sub- re gĩa Noroeste apresentou, em relação às outras, um crescimento surpreendente, de 1960 a 1970, evidenciado por grande adensamento ıtbano, paralelo ao quase desaparecimento da população rural. Des

(1) Cāndido Procópio Ferrelra de CAMARGo et al11 - são Paulo 1975 - Cresclmento e Pobreza-São Paulo-1976- p. 29 e 30

(2) Plerre GEORGE- A Geografia Ativa - Difusão Européia do Livro - 1968 - p. 265 e 266 
ta forma, a maioria dos municípios localizados nesta regiāo pas saram a funcionar como cidades-dormitório da ārea metropolitana (3).

Dentro desse contexto, foram significativos os da dos referentes ao municiplo de Jandira. DaI porque, com base nas taxas percentuais do crescimento de sua população, 1sto é, de 38,778 no período de 1950-1960 a 510,168 na década de 1960-1970, aliadas à urbanização total do município, definiu-se o tema a ser desenvolvido no presente trabalho: "O Municiplo de Jandira no Con junto Metropolitano de são Paulo".

Este municipio (fig I) situa-se na sub-região admi nistrativa Noroeste (4) da Grande são Paulo, distante $32 \mathrm{Km}$ da ca pital (marco zero) por ferrovia e $35 \mathrm{~km}$ por rodovia.

Apōs um melhor conhecimento da ärea,propiciado por enquetes, entrevistas, lelturas e viagens ao municipio, o traba tho se concentrou mais na caracterização de Jandira, mediante o estudo de seu passado e o enfoque de sua situação atual.

(3) Seplan-Gegran - P.M.D.I. - Plano Metropolitano de Desenvolvi mento Integrado - p. 7

(4) Sumário de Dados da Grande São Paulo, 77 - Governo do Estado de São Paulo, S.N.M.-Emplasa-p.9 - "Cabe ressaltar, ainda, que a agregação dos dados em sub-regiōes da Reglão Metropolitana não obedece a nenhuma norma oficial. O GEGRAN dividiu a Gran de são Paulo em sete sub-reglōes: Centro, Nordeste, Leste Sudeste, Sudoeste, Noroeste e Norte - critérlo adotado também pelo PMDI - Plano Metropolitano de Desenvolvimento Integrado, elaborado em 1970 e alnda em vigor para a Região. Para efei tos de representação com direito a voz em suas reuniōes, decI diu o CONSELHO DELIBERATIVO DA GRANDE SÃO PAULO-CODEGRAN, dî vidir a reglão nos quadrantes: Leste, Sul, Oeste o Norte, além do Centro, constituido pelo municiplo da Capital. A desagre gação aquil adotada segue basicamente a do GEGRAN, tendo sidō. as sub-regiões sudoeste e Noroeste, reagrupadas em três: Sudo este, Oeste e Noroeste, e a sub-região Centro acresclda do Mu nicipio de Osasco." 
Estabeleceu-se como hipótese o fato provável de que a população ativa do município trabalha geralmente na Grande São Paulo, com a qual mantém relaçōes de comércio e prestação de serviços em grande escala. Jandira poderia, portanto, caracteri zar-se pela função de cidade-dormitório.

Determinada a hipōtese de trabalho, traçaram-se os sequintes objetivos:

- verificar as relaçōes de Jandira com as demais cldades da Gran de São Paulo e até que ponto essas relações Influenclaram na organização do espaço do município;

- estudar a natureza e definição dos processos que condicionaramo crescimento populacional de Jandira, acompanhado de uma quase total urbanização;

- levantar os aspectos fisicos, humanos e econômicos, procurando inter-relacionar os mesmos, numa tentativa de perceber o espaço de Jandira como um todo, integrado na Grande são Paulo.

Positivada uma certa carêncla bibliográfica, tor nou-se imperativo o conhecimento da ārea através de viagens que possibilitaram observações diretas.

A técnica de entrevista mostrou-se favorável para o desenvolvimento do trabalho, uma vez que se conseguiram informa ções válidas atravēs de pessoas como o Sr. Osvaldo Sammartino, fl tho do fundador da cidade, Sr. José Albino Pereira, corretor de imóveis no local desde 1945 , Sr. José Nunes, que chegou à cldạ de em 1949, Dona Maria Martins Góls e Dona Maria Aparecida de Godoy.

Verificou-se que o material cartogrāfico dispon vel, ao inicio do trabalho, em 1973, consistia em: carta topográ fica do IGG - escala 1:10.000; folhas de carta de Itapecerica da 
Serra, do IGG - escala 1:50.000; carta planimétrica-escala 1:5.000 (adquirida na prefeitura Municipal); fotografias aéreas na escala 1:25.000 - 1962 do recobrimento aerofotogramétrico da Secretaria da Agricultura do Estado de São Paulo-Instituto Agronōmico e da United States Air Force, na escala de 1:20.000 - 1965.

Atualmente, 1979, para a área, além desse material, existem folhas de carta dos mapeamentos nas escalas de 1:10.000 e 1:2.000 do Sistema Cartográfico Metropolitano da Grande são Paulo SCM, bem como fotos aéreas dos recobrimentos aerofotogramétricos do Instituto Brasileiro do Café - IBC, na escala de 1:25.000-1972, e do SCM na escala de 1:8.000, de 1:40.000 do mesmo ano (1972); $1: 16.000$ e 1:60.000 de 1974, e as mals recentes, 1977/78, nas es calas de $1: 8.000$ e $1: 40.000$.

A situação do mun1cípio, em 1969, foi obtida através do Cadastro Imobiliário Fiscal da Prefeitura, que registra ārea construlda e ārea vaga por quadra.

Concluído o reconhecimento da área, partiu-se para a elaboração de um questionário voltado para as características da habitação, vida de relações e dados pessoais dos componentes famí liares.

A fim de apurar se as indagaçōes estavam de acordo com os objetivos propostos, elaborou-se primeiro, um questionárioteste, que por sua natureza foi aplicado em apenas quinze re sidēncias. Codificado e tabulado, aparentou cobrir o objetivo da pesquisa.

Preparado o questionārio principal, procedeu-se à escolha da técnica de aplicação, que recalu, após cuidadosas pẹ quisas, na de amostragem sistemātica, ou seja(5):deteminada uma casa como (5) Brian BERRY e ALAN BAKER - Anãilise Espacial-Textos Básicos.P.3 
a primeira, a partir dela estabelecia-se um intervalo fixo três residēncias. Apenas na área central da cidade se fez uma pesquisa global, já que o número de habitações é muito inferior ao de estabelecimentos comerciais e de serviços. Para aplicação do questionário, sentiu-se necessidade de uma carta cadastral. Dada a sua inexistência, elaborou-se uma, a partir de levantamen Y em campo. Nela foram lançados todos os tipos de uso, de acor 4 com as convençōes prē-estabelecidas. Todas as edificaçōes fo 1 m mapeadas com seus respectivos números e localizaçāo correta I logradouro. Assim, os responsáveis pela aplicação dos questio r Irios já os recebiam com os devidos endereços e estes só eram al t rados quando a pessoa não era encontrada na residéncia ou nega $\checkmark$-se a responder. Como as respostas deveriam ser precisas, a c licação ficou a cargo de apenas cinco entrevistadores de nÍvel liversitário. E, como só se dispunha dos fins de semana para a trefa, foram necessários oito meses para aplicar todos os ques tionários.

Segundo o Censo de 1970, Jandira contava com dois I 1.1 quatrocentos e setenta e quatro imóveis ocupados. Conseguiu:, malgrado o tempo disponivel e outros percalços, uma amostragem 1. 31,488 através de setecentos e setenta e nove questionārios a 1 licados. Com efeito, dos doze mil quatrocentos e noventa indivi ' Ios que constituiam a população no último recenseamento, atingiu : p três mil novecentos e cinquenta e oito,vale dizer, 31,68 d da chele total.

Na fase seguinte do trabalho, os questionários fó m codificados e tabulados manualmente. Ao iniciar-se a redação, 'm utilização dos dados coletados, deparou-se com a falta de in rmaçoẽs referentes a: causas da escolha de Jandira para fixação t. residência; nîvel de vida no tocante à alimentação e meios utî lizados para construção da casa. Tornou-se, pois, indispensāvel a elaboração de mais dols pequenos questionários, com a finalıda de de levantar os elementos omitidos nos primeiros. Os questioná rios adicionais foram confiados à diretora de um colégio, que os distribuiu aos alunos de $3^{a}$ e $4^{\text {a }}$. séries, com a recomendação de 
que pedissem aos pais para os responderem.Os dados, assim obtidos e tabulados, cobriram as falhas.

Poder-se-ia questionar até que ponto a segunda a mostra foi válida. Entretanto, é indubitável que foi útil na me dida em que complementou as informações constantes do primeiro le vantamento, sem apresentar contradições com os resultados até en tão colhidos.

Por meio de fotointerpretação, com emprego de fo tos āereas de 1962-1965-1972 e 1977,em diferentes escalas bem como carta 1:25.000 do SCM., descortinou-se a evolução do uso do solo num período de quinze anos.

As fotografias, bem como os grāficos, plantas, ma pas e quadros, têm a finalidade de llustrar e facilitar a inter pretação dos dados.

Ao lado disso, procedeu-se à pesquisa e coleta de material em diferentes ōrgãos, como:

- Prefeitura de Jandira, principalmente no Setor de Cadastro;

- Cartório de Registro Civil de Jandira;

- Escritório da Sabesp em Jandira e em São Paulo;

- Escritório da Light de Jandira;

- Delegacia de Pollcia de Jandira;

- Centro de Saúde de Jandira;

- Secretaria de Transportes - Departamento de Estradas de Rodagem;

- Cartório de Registro civil de Jandira;

- Cartório de Registro de Imóvels de são Paulo:

- Estação Ferroviária Júlio Prestes-Departamento de Estatistica; 
- Viação Santa Clara;

- Himalaia Transportes Turismo Ltda.;

- Secretaria de Educação do Estado de São Paulo;

- Instituto Geográfico e Geológico do Estado de são Paulo;

- Bibliotecas:

- do GEGRAN, atual Emplasa;

- da Secretaria de Negócios Metropolitanos;

- da Secretaria de Economia e Planejamento;

- do I.B.G.E. (atual FIBGE);

- do Departamento de Geografia da F.F.L.C.H. da U.S.P.;

- do Arquivo do Estado de São Paulo;

- Municipal de São Paulo;

- da Faculdade de Filosofia, Ciências e Letras de Presidente Prudente.

Estudar os municipios da Grande são Paulo tem sí do,ultimamente, um dos importantes objetivos de alunos de pös-gra duação do Departamento de Geografia da Faculdade de Filosofia, Le tras e Ciências Humanas dessa Universidade. Cotia, Embu, Santana do Parnalba, Barueri e Salesópolis já foram focalizados. Este mo desto trabalho sobre Jandira é,pois, uma tentativa de colaboração no sentido de levantar caracteristicas e problemas do município e compará-lo com os demais, de modo que possam ser analisados globalmente, dentro da linha já seguida pelos esforços anteriores. 
1. Jandira e sua históría

A titulo de, tão somente, fornecer subsidios para uma satisfatōria compreensão do fenōmeno urbano desenvol vido no muntcípio, far-se-ã un resumo de sua evolução . Al1as, um resumo despretencioso, passivel de revisões e crit cas, baseado que estā em escassos documentos e entrevis tas com moradores antigos. Tais depoimentos conflitam em algumas informações, enquanto que outras talvez não tenham sido objetivas a nível desejävel.

Ao que informa o Sr. José Albino Pereira, morador e corretor de 1móveis desde 1945, Jandira teria entrado para a Histórla com a concessão, por parte do Governo da então Provincia de são Paulo, de uma sesmaria ao coro nel Jesuíno Pereira Leite. o beneficiário deveria morar nas terras e ainda promover seu povoamento. No entanto, em pesquisa junto ao Arquivo do Estado, nos volumes re ferentes às sesmarias, não se encontrou citação de tal personagem. Por putro 1ado, Benedito Perelra Leite, neto do citado coronel, afirmou que seu avô adquiriu de Joa quim Pereira Leite, tio do informante, uma gleba de tex ras localizada na área onde atualmente se encontra a Pedreira, mas, a familla não possui provas documentais disso. Essas terras ficaram por direito de posse para descendentes de antigos escravos.

Outro fato, este documentado, refere-se à organ 1 zação da Estrada de Ferro Sorocabana. Francisco Antonto Gaspar declara que o Governo Provincial, pelas Leis no 34 de 24 de março de 1870 e no 33 de 29 de março de 1871, concedeu privilégio para a construção, custeio e 
gozo de uma via férrea que ligaria a fábrica são João de Ipanema (Sorocaba) a São Paulo, passando pelas cidades de Sorocaba e São Roque.

As terras do coronel Leite e a área a ser ocupada pela Sorocabana pertenciam, jurisdicionalmente, à cldade de cotia, que obteve, em 1856, autonomia em relação a são Paulo, a que estivera ligada desde meados do século XVII, quando fora fundada por Fernão Dias Pals e Gaspar de Go doy Ferreira.

Em 1912, um paulistano, dono de uma panificadora localizada na rua do Triunfo, em São Paulo, por motivos de saūde, Instalou-se na ārea da atual Jandira. Seu nome era Henrique Sammartino. Ele adquiriu terras de dois proprietários. Pelas transcrições nos. 66.526 e 67.587 do Primeiro Cartório de Imóvels (fig. II), esses terrenos seriam partes do"SItio das Palmeiras" (fig. III). Entre tanto, o Sr. José Albino Pereira diz que o local era de nominado "sitio da Passagem", parcela, isto sim, da Fazen da das Palmeiras". Segundo ele, a gleba continha uma pas sagem obrigatóría ligando Cotia a Santana do Parnaíba e Itu, daI a razão do nome. Em 1819, Auguste de Saint-H1la1 re, em sua viagem de são Paulo a Itu, cita esta passagem obrigatória (estrada velha de Itu), dizendo não ser a preferida pelos tropeiros, por fazer uma volta considerá vel. O referldo autor utilizou-se dela unicamente para passar pela casa de campo de un amigo.

Sammartino deu inicio ao desenvolvimento de sua nova propriedade. A apresentação, um tanto laudatōria, do Relatōrio Administrativo de Jandira de 1965-68, tece co mentários a respelto da dedicação e energia do entāo no vel sitiante. Um dos pontos destacados le também citados 
et 30,00

SILVIO DE BUEno vidiaAl. Merventuario vilelitolo do Primotro Cartorlo de Regietro de Imoveia da oomarca da Capilal. do Eatado do 810 Paulo. Ropablion Fodorativa do Brasil. eto.

CERIIICA,

- podido vorbal de peseos interessade, que revondo no cartório a cou cargo, os livros reapectivos, deles consta ques 1)conforne a transarigĩo púmero 66.526 (ssesente - selo all quI nhento - vinto - eols), folta on data de vinte - tros de - 1 abril de all novecentos - doze, Raphael Lombardo - ane nulher

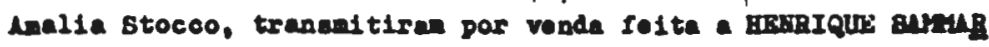
2INO, nos tereos de escriture de 21 de abril de 1.912, de notae do $5 e$ taboliño desta Capital, pelo valor do sele contos do róio, partes do eltio denonirado "Palmelras", no quiliboe-1 tro 32 da linhe sorocabana, tregueste de Ootin, teo an wa in togridede confina can terras de Jose Manuello, con Jaseonimol Porelre - linha sorocabana onde aede 4 quilínetros, wale oul

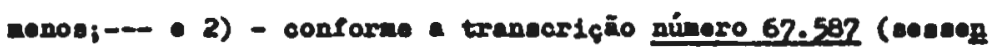
te oote nil guintiontos a citonte osto), foita an date dol quntorzo de Junho de 1.912, Lourenço Beneducc1 - wue mulher -

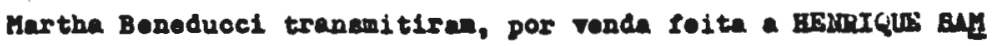
MARIINI, nos toreos de encriture de 12 de Junho de 1.912, de notas do 39 tabolizo desta capital, pelo velor de doie contos de réls, usa parte de terras no eitio denominado "Palneiras", no quilómotro 32 de Batrade de Jorro Borocabena, an V1la, hunicipio - Ireguesia de cotia, dividinda an oue integridedo,-1 de un lado con José Manuello, de outro con herdelroe de Jan-l quil Porelra, - de outro con o lesto da Eatrada do Jorro Boro cabara, sendo dito aitio de forma irregular.-- 0 reforido : -

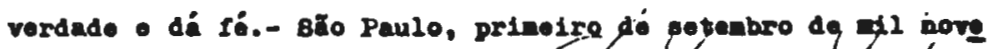

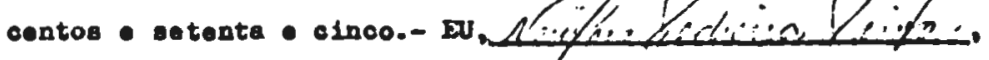

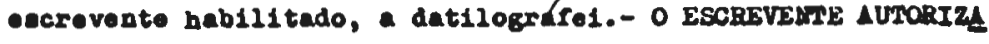
Do Alarie Elechado.....- 
por Albino Perelra) fol a iniciativa de Sammartino

construir junto aos trilhos da estrada de ferro uma peque na estação (foto 1 ). Há indíclos de que, inicialmente, a Sorocabana prometera que nela parariam os trens mistos(6) - já que na época os de subúrbio atingiam apenas Osasco.

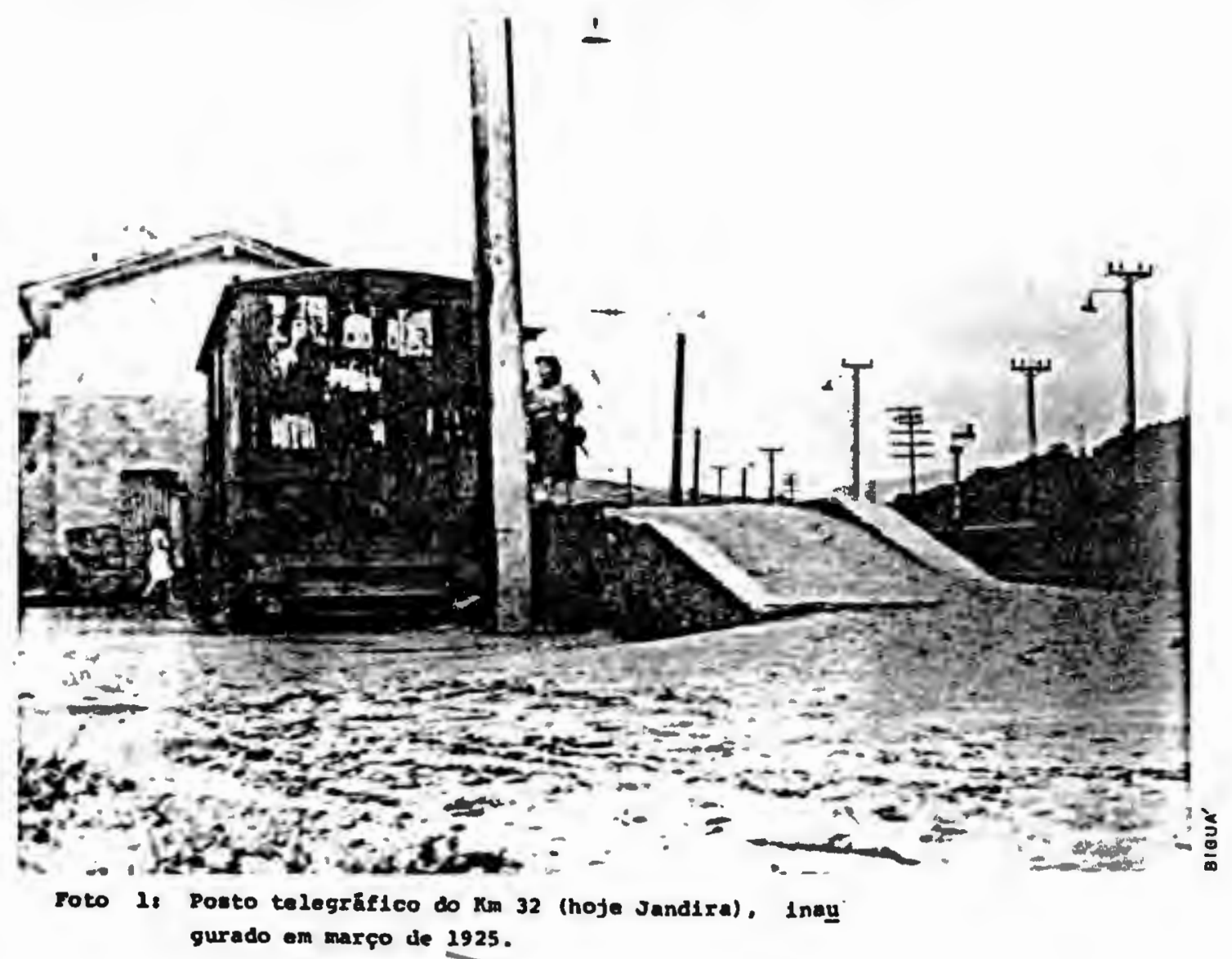

Provavelmente, a viabilidade econômica desta ini clativa era discutivel, pois nem mesmo a então escassa lenha se carregava, tanto assim que sammartino teve que lutar bastante para ver seu desejo concretizado. Construí da a estação, ficou conhecida iniclalmente como Parada do $\mathrm{Km}$ 32. Apenas em 5 de setembro de 1930 (7) a chamar-se Jandira.

(6) São trens de passagelros compostos de poucos vagões, que percorrem curtas distâncias, transportando tambēm carga.

(7) Estrada de Ferro Sorocabana, Relatório 1930 - p.134. 
Anteriormente, o proprietário do sitio cedera dez alque res de terra para o Mackenzle College, que o povo chamava de Escola Americana. Na ārea cedida, os beneficiārios criaram um" "campus"para estágios prāticos dos alunos de Engenharia, especialmente para levantamentos topográficos. (foto 2).

Em 1923, a mantenedora do Mackenzle College fundou, nesse mesmo terreno, um seminário presbiteriano que fun clonava em regime de internato para alunos vindos do in terior do Estado (8). Isso não impediu, entretanto, que a ārea dos estagiários permanecesse funcionando. 0 " cam pus " abrigava o prédio da escola, casas para professores, refeltórios, alojamentos para moças e rapazes, um anfitea tro com dois mil lugares e un templo. (foto 3).

Após 1945, o seminārio, desligando-se do Mackenzie, passou a chamar-se Instituto José Manuel da Concelção . (foto 4). Além dos cursos teológicos, a instituição pro porcionava instrução leiga até o nivel ginasial. Por vol ta de 1969, a entidade delxou de funcionar (9).

(8) Juergen Richard LANGENBUCH em sua obra "A Estruturação de Grande São Paulo" p.280, explica a instalação no local. "Os seminários teológicos protestantes, Instala dos en determinados subúrbios (Rudge Ramos, Riacho Grañ de e Jandira), não visando a população destes, mas $\overline{0}$ confunto da Grande São Paulo. Uma vez pertencentes a Igrejas protestantes de origem anglo-saxônica, é pos sivel que tal localização corresponda a alguma tradí ção dos EUA, pals em que 08 subürbios 8 ão mals valori zados do que entre nós".

(9) Atualmente, 1979, as residências e mesmo o prédio do coléqio encontram-se alugados como moradia. Hã doze fa milias presbiterianas morando no local. 


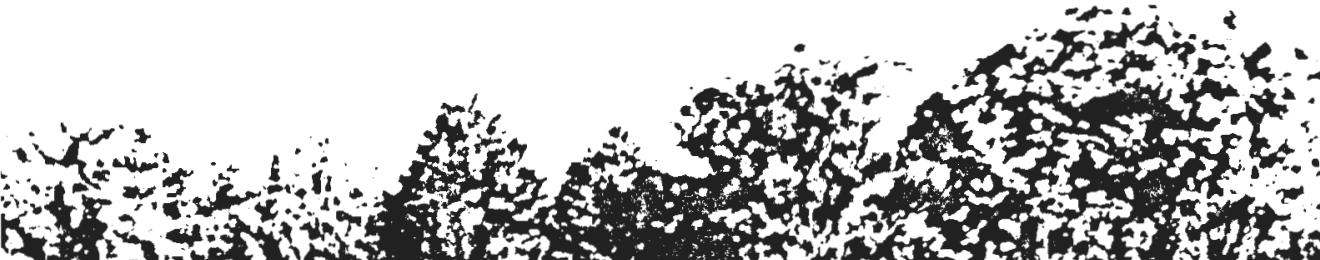

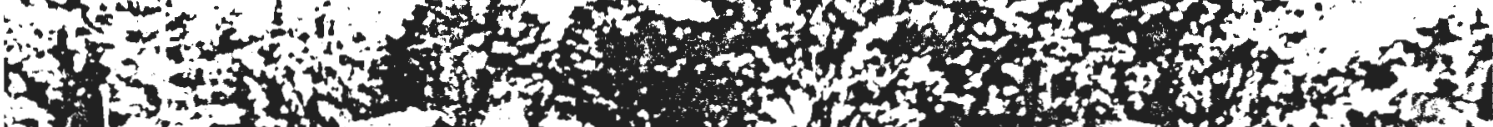

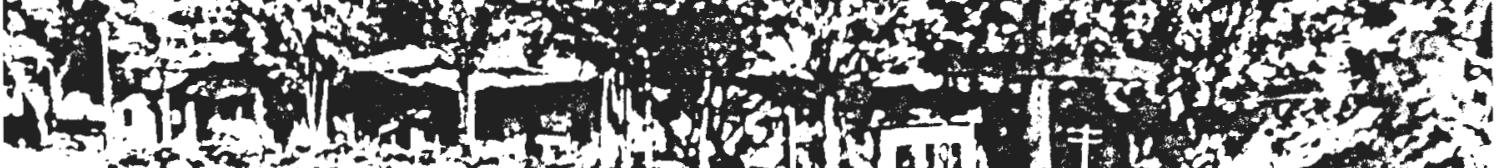
(2) Ald

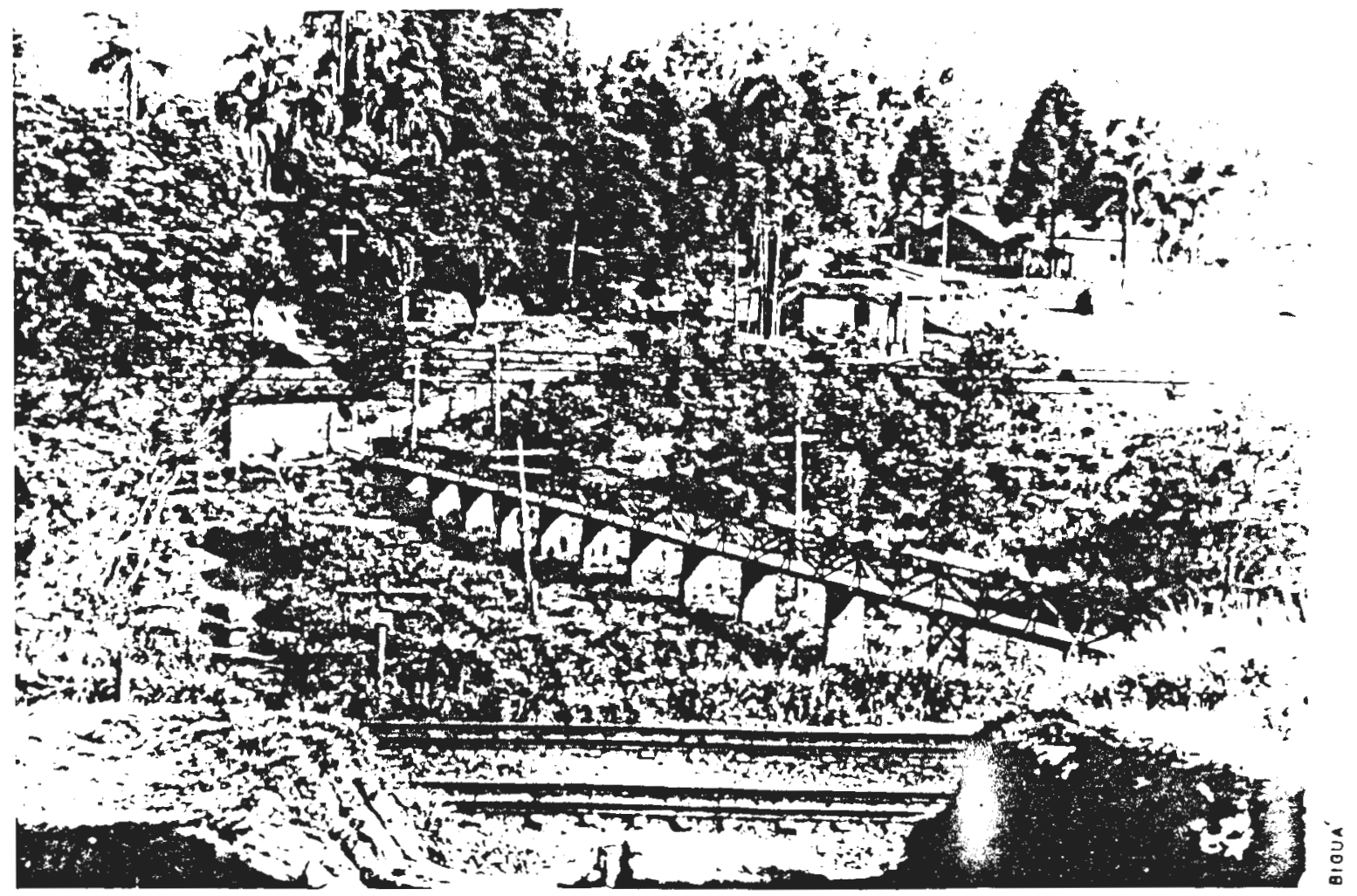

Foto 2: Vistas parcials do Mackenzie College. Na foto su perfor, a parte localizada ao sul da ferrovia. agregava prédio da escola, refeltōrio 1greja, an flteatro, casa para professores a alojamento pa ra rapazes. Na foto inferior, ao norte da ferro via, o alojamento feminino, local hoje ocupado por una fäbrica. 


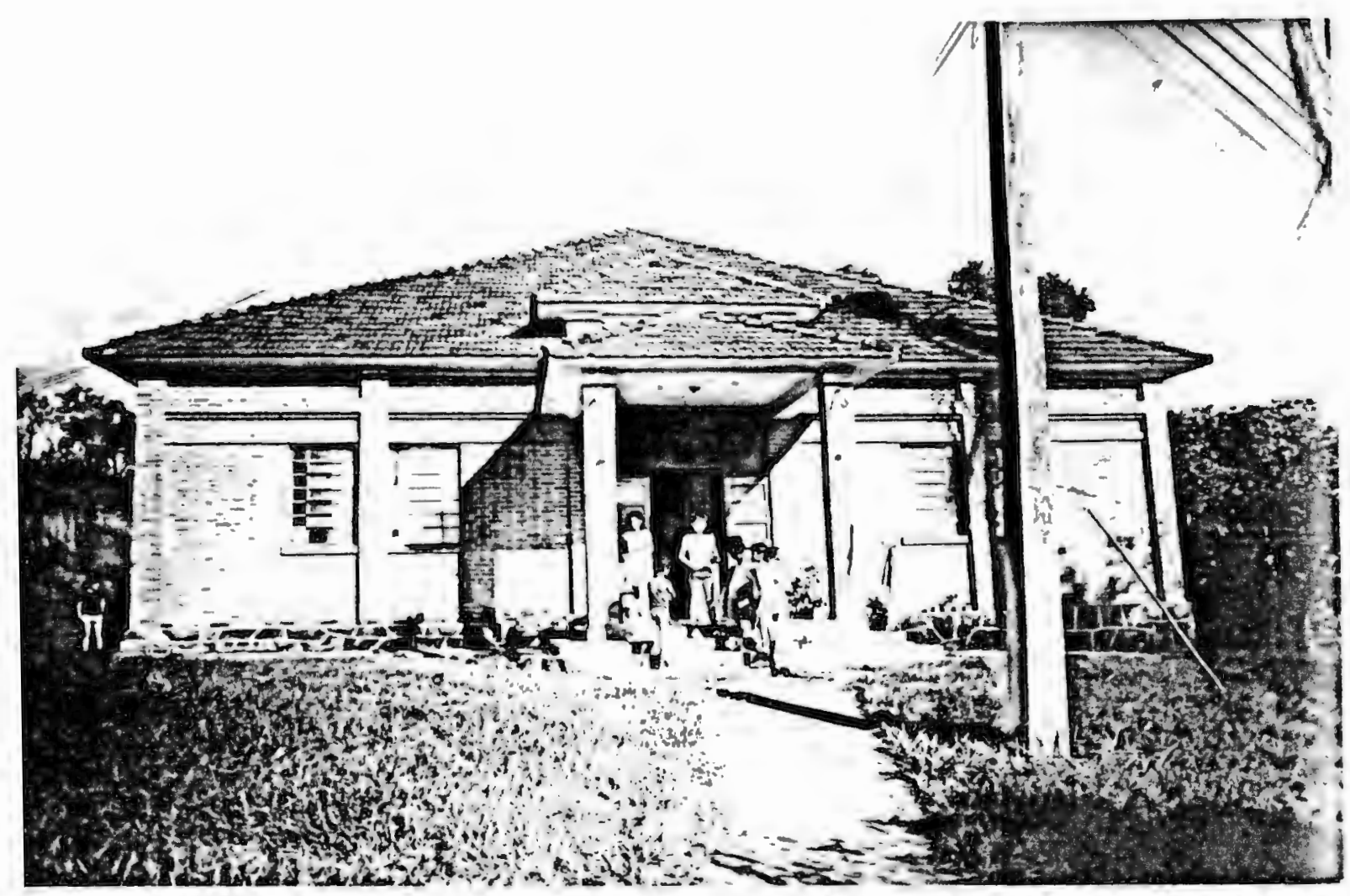
4
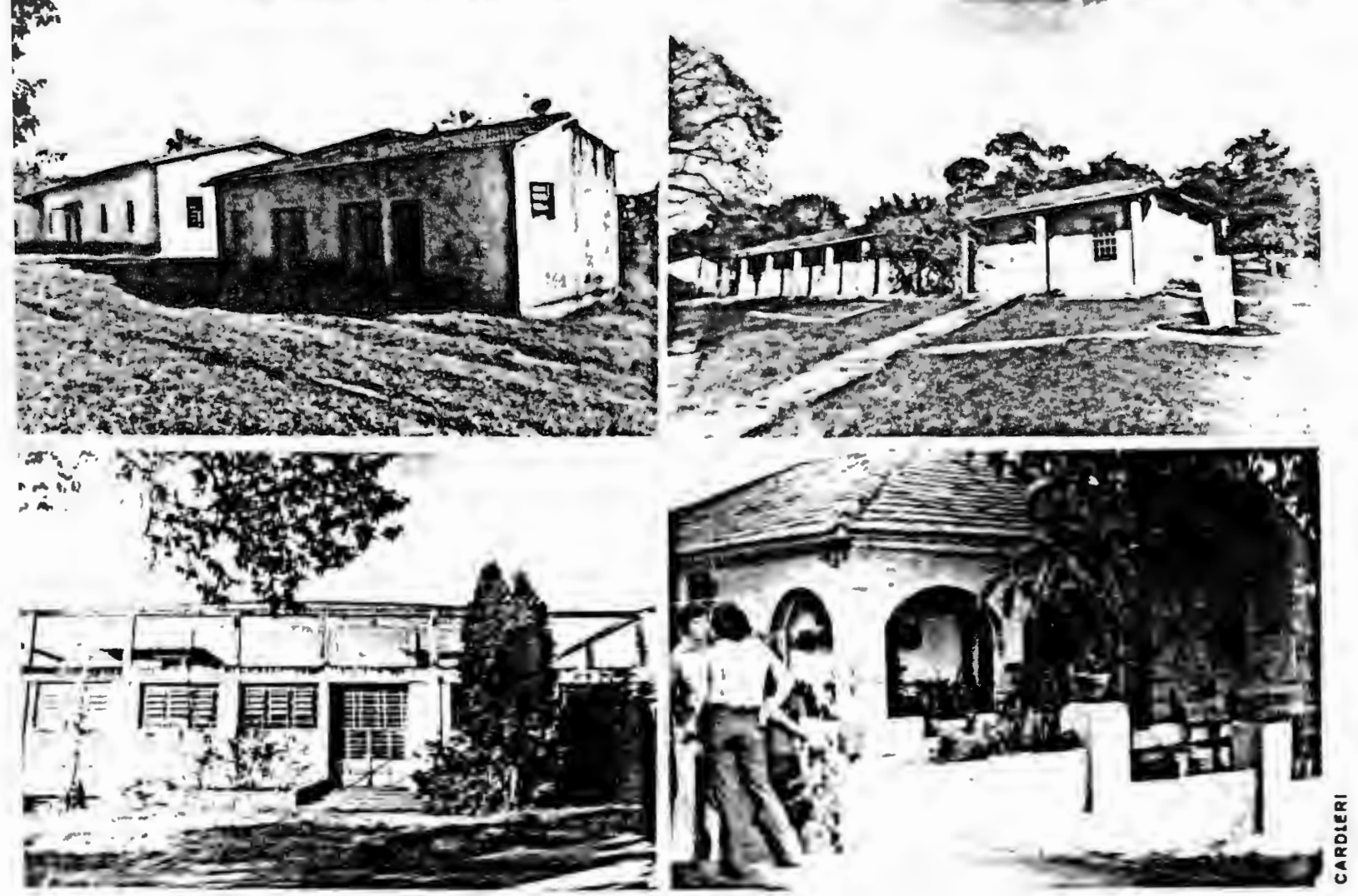

Foto 32 Ampectos do Mackenz10 Colleges

3a - prídio destinado a escola, otillado atual

mente, 1979, como casa de farrila;

3b - refeitōrio para ectudantes;

$3 c$ - o pxidlo do 1greja, atualmente desativados

3d - anfleatro para dues inll pessoas, tanbēm de sativado:

36 - casa para professores. 


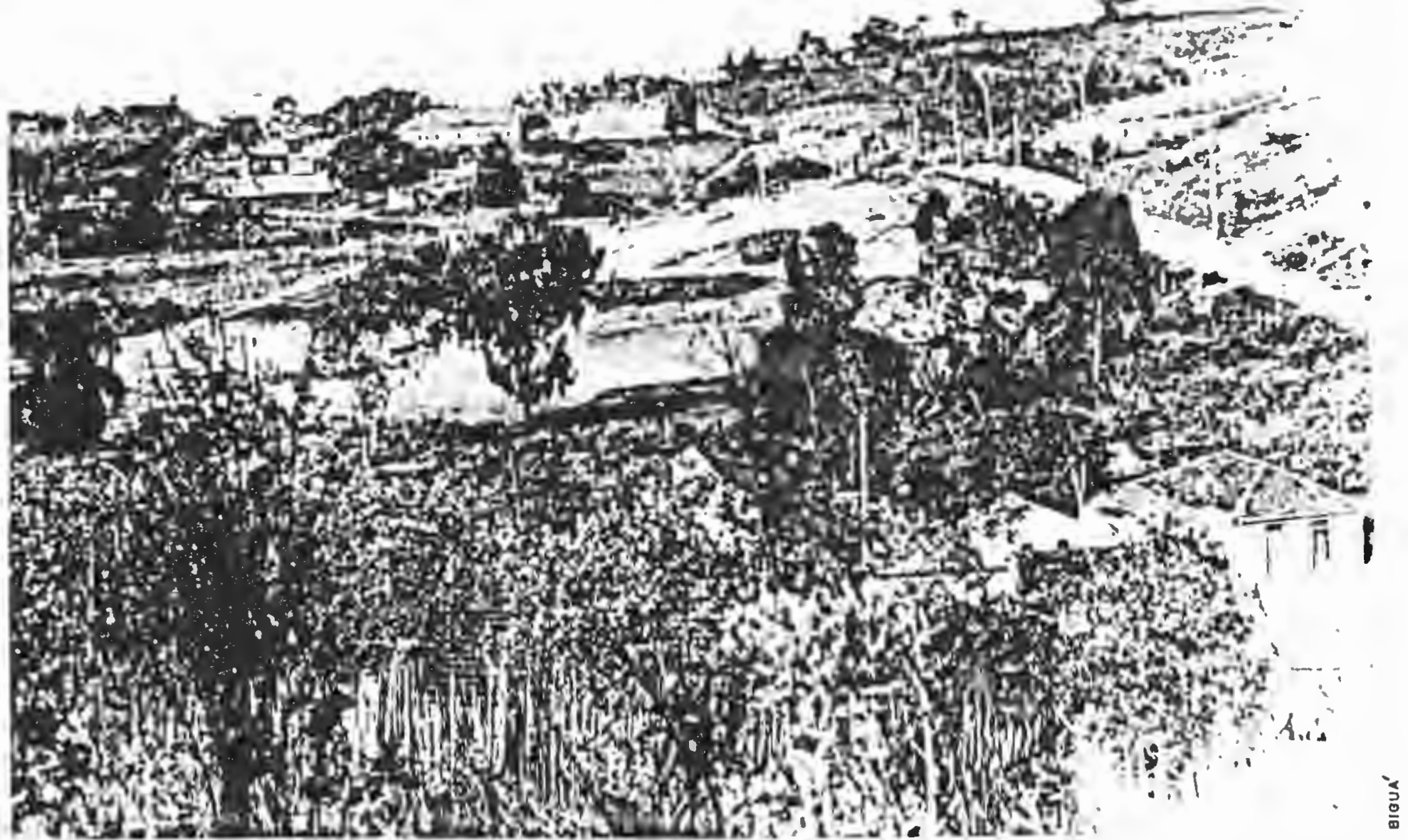

roto 4 Vilta panorânica do Distrito de Jandira.

Em primelro plano, ¿ direlta construçöes da Av. Concelção Sammartino e, ao fundo, prédlos do Coléglo J.M.C., ainda em funcionamento. 
No sitio de Itaqué (atual Itaqui), onde Saint-Hilaire se deteve em sua viagem de são Paulo a Itu, os moradores de então eram "pouco abonados, só possulam pastagens e cult $\underline{1}$ vavam apenas para satisfação dasubsistêncla das prōprias famillas. Compravam muares que, internados em seus pastos, alugavam aos proprietários dos engenhos de açúcar ou os empregavam diretamente no transporte de açúcar, sobre pagamento previamente ajustado" (10).

Tal situação não se alterou multo até 1944, pols o SIt1o das Palmeiras funcionou como propriedade rural até essa data, ocupando-se das atividades de olaria, criação de ga do leiteiro e fornecimento de lenha para a Estrada de Fer ro Sorocabana (atual FEPASA). Por ocasião do falecimento de Concelção Desidério Sammartino, esposa do proprietário, este resolveu partilhar as terras, que perfazlam un total de 88,5 alqueires, entre si e os nove filhos. (Fig. IV e F1g. V).

Conforme assentamento de $30 / 3 / 44$, da $1^{a}$. Circunscrição, a divisão resultou liquida e certa para os beneficiārios. 0 Sr. Albino Pereira, porém diz que, na verdade, era apenas a metade das terras. A outra metade, por problemas de "direitos 1dea1s", só fol negoclada multo tempo depois . apōs uma decisão judiclal que beneficlou as pessoas pos suidoras desses "direitos".

(10) Augus te de SAINT-HILAIRE, Viagem à Provincla de são Paulo. p. 203. 


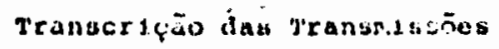

$66-12.551$ a 11.690

T. no 11.659

Nünoro ac. ant. 66.526 da 1 a cire.

circunberiçães: Distrllo de cotia

Denom 1 naçäo ou rua e no: lugar denominado sltlo das Palmelras, do lado esquerdo da linila ferrea ltuada na estação de Jandira, (Estrada de Ferro Sorocabana).

Caractcrist1cos e Confrontacões: Uma parte de Cr\$. 227.037,50 ao viúvo e uma parte do valur de cr\$. $9.556,94$ e $1 / 9$ a cada um dos adquirentos em uma das glebas de terras denominadas sitio das Palmeiras, do lado esquordo da linha lerrea, aituada na es tação de Jundira, (Estrads de Ferro sorocabana), culturas - á tas de relevo levemente acidentado, contendo nas proximidades da estaçäo: a) casa de moradia, en parte nusobradada, contendo 3 cômodos em clima, forrados assoal hados, 3 còmodos no pavimen to térreo, tijolados, uma sala forrada e asaoalhada, cosinha banheiros cimentados, - Instalação santiārla. b) casa para operário com quatro cômodos plso interno aplloada e telha van. c) un saláo para escola, telha van e plso em terra. Tem esta gleba a área de 88,5 alqueires a as seguintes alvisas partindo do ponto de interseç̧ão da cerca divisooria da E.F.s. com o cór rego que passa no boeiro exiatente mals ou menos no $\mathrm{km} 30$ mals $80 \mathrm{~ms}$. Bohe por este córreqo dividindo con Francisco de Matos Plmentel e Benedito Motta, seguindo dal sempre córrego acima, dividindo com herdeiros de Jesulno pereira lelte e depois pas sando a fazer divisa com os mekmos por un valo existente até encontrar com um outro cōrrego, descendo por esse dividindo com herdelros de José Joaquim de ollveira de Camarqo comunente aha mado Josó Marmelo, atö Interceptar a cerca da E.F.s. mais ou monos no $\mathrm{Km} 32$ mal $20 \mathrm{~ms}$. seguindo por essa estrada as terras do Mackenzie College as quais contorna atingindo novamente a linha férrea pela qual segue até o ponto de partida, admitindo d1visão em alquelres. Avalitida em Cr\$. 313.050,00.

Mome, domicllio e profissão do adquirente llenrique saranartino, viüvo: Mfonso Sammartino casado com Predeliana Rosa Samrartino; doms. no $\mathrm{Km} 32$ da E.F.S., El1zabeth Sammart1no Del Nero casado com Ermelindo Del Nero, doma: en Plracicaba, n/Estado; Josefina Sampartino Deocloedt casada com. Alberto Moel Deocloedt, doms. n/capltal, Domingos Vicente Sammartino casado com Isabel Bueno samartino, doms. n/capital, Lucla sammartino concalves Cristi no casada com Waldomiro Goncalves Cristino, doms. no Rio de Ja neiro, Virginia Sammartino Albuquerque casada com José Albuquex que, doms. n/capital, Henriqueta Sammartino Goncalves Cristino casada c/ Artur Gonçalves Cristino doms. n/capital, Oswaldo sa mmartino, casado com Ignez Branco Sammartino doms. no $\mathrm{K}_{\mathrm{m}} 32$ da E.F.S. Q Q1inda Sammartino colteira e maior dom. no kn 32 da E.F.s.

Nome, domiclilo a proflssão do transmitente: - Espólilo de con celçĩo Desidério Samartino.

IItulo: Partilha julgada por sontença de 30 de março de 1944. Forma do ritulo, dada e serventuärlos carta de sentença formal de partilha datada de 17 de abril de 1944, subscrita pelo es crivão sucessor. Off́cio celen aranangy e assinada pelo Julz dé Direlto adjunto da la.vara Dr. SIIvio Barbosh, ambos de Familia - das sucessōes desta capital, extralda dos autos de Inventírio dos bens delxados pela flinada transmitente.

valor do contrato - Cr\$. 313.050,00

Certldão estadual ne $1 \mathrm{j} .299$

$18.181 / 1943$ 
A parcela que coube ao prōprio Henrique Sammartino fol loteada com o nome de Vila Anita Costa (fig VI e VII), constituindo o inflcio do processo de urbanização de Jandi ra. Éam sessenta lotes de $20 \times 50 \mathrm{~m}$, vendidos, segundo prólogo do Relatōrio Administrativo, em sessenta dias, o que, para a época talvez fosse um fato, interessante.O Sr. Albino Pereira completa a informação, afirmando que o va lor de cada lote era de três contos de réls, com pagamen tos parcelados de trinta mil réls por mês, flcando a dî vulgação por conta da propaganda pessoal. Esclareça-se que este loteamento compreende três partes, loteadas reg pectivamente em 1944 - 1949 e 1965 .

o nome Vila Anita Costa fol uma forma de homena gear a esposa do então governador Fernando Costa, grande amiga da falecida Concelção sammartino.

Convém sublinhar que este loteamento fol também o núcleo urbano pioneiro da futura cldade, estendendo-se em torno de um elxo que partia da praça Dr. N1lo Andrade do Amaral (foto 5), atual praça AnieloGragnano, e dirigia- se para o sul.

As informaçōes extraídas de documentos e entrevig tas diretas Indicam que o processo de urbanização se deu ao sul da ferrovia. Entretanto, Langenbuch - 1971, refe rindo-se aos "povoados-estação", diz:"Em Jandira, por e xemplo, a mals antiga casa comercial $e^{-}$um estabelecimento que ainda hoje guarda o aspecto inconfundivel de venda calpıra.Ao contrário do atual "subúrbio-dormitōrio", surto ao sul da ferrovia, a citada venda se situa ao norte da mesma, em melo a algumas casas velhas que parecem corres 


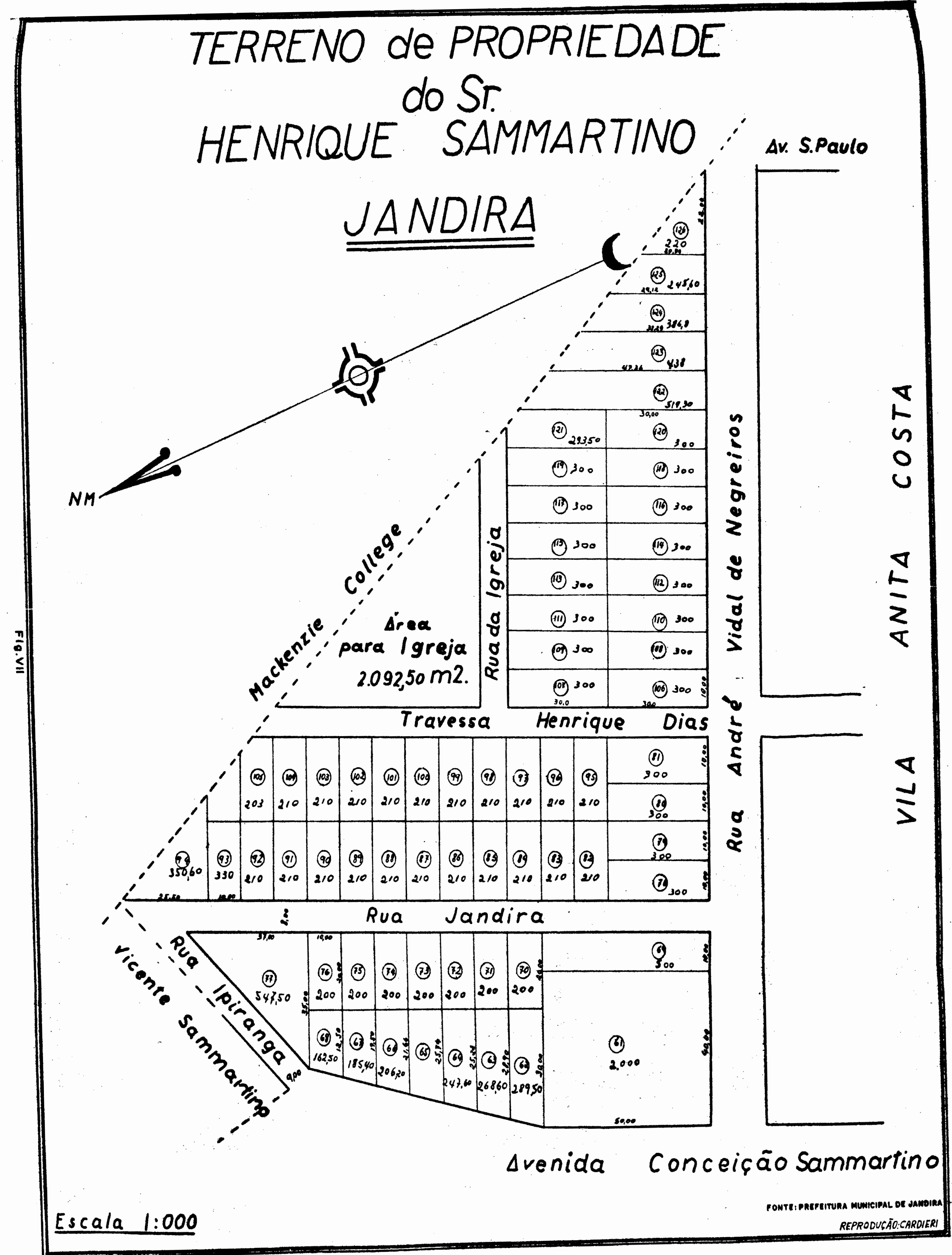




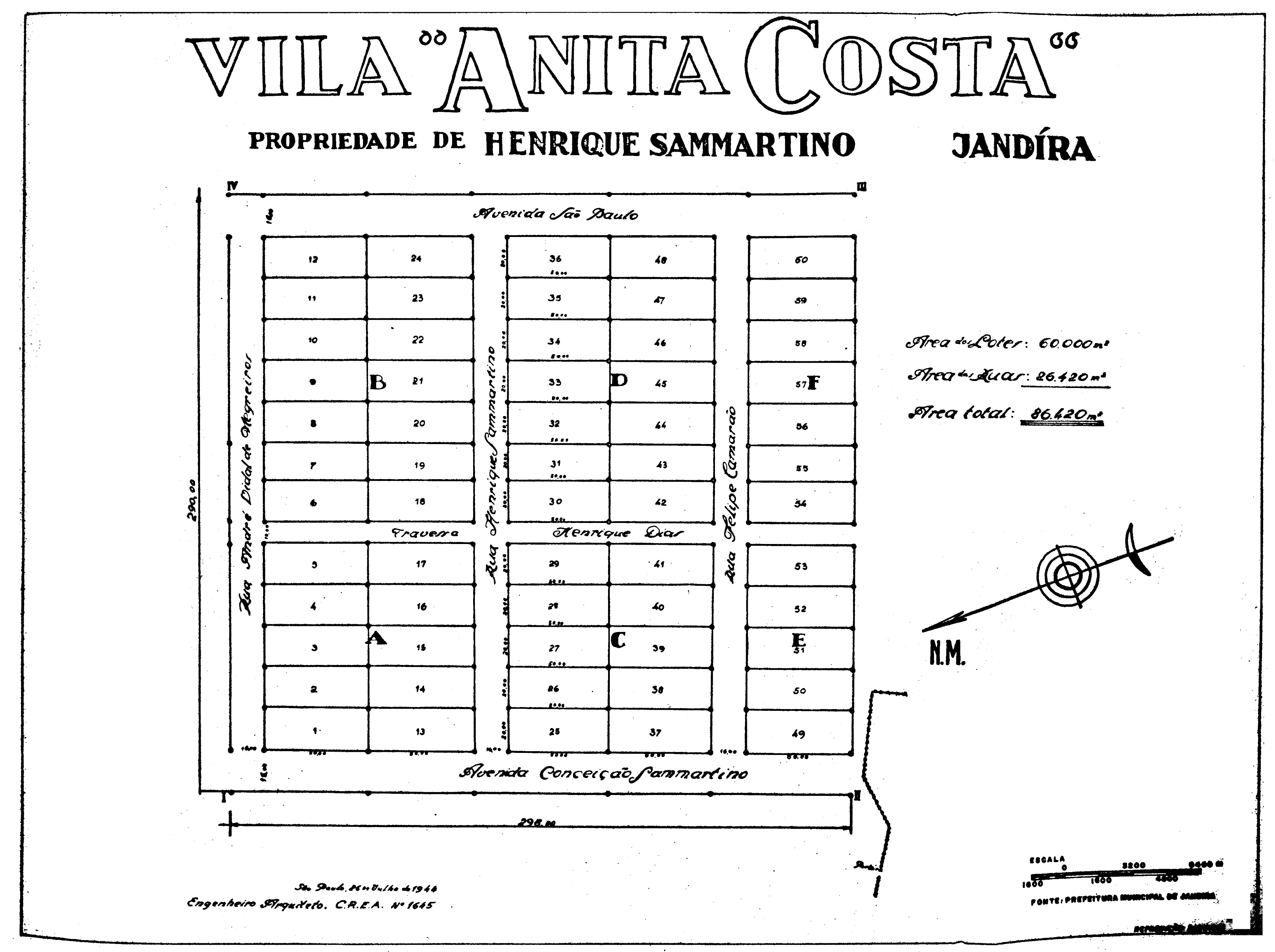




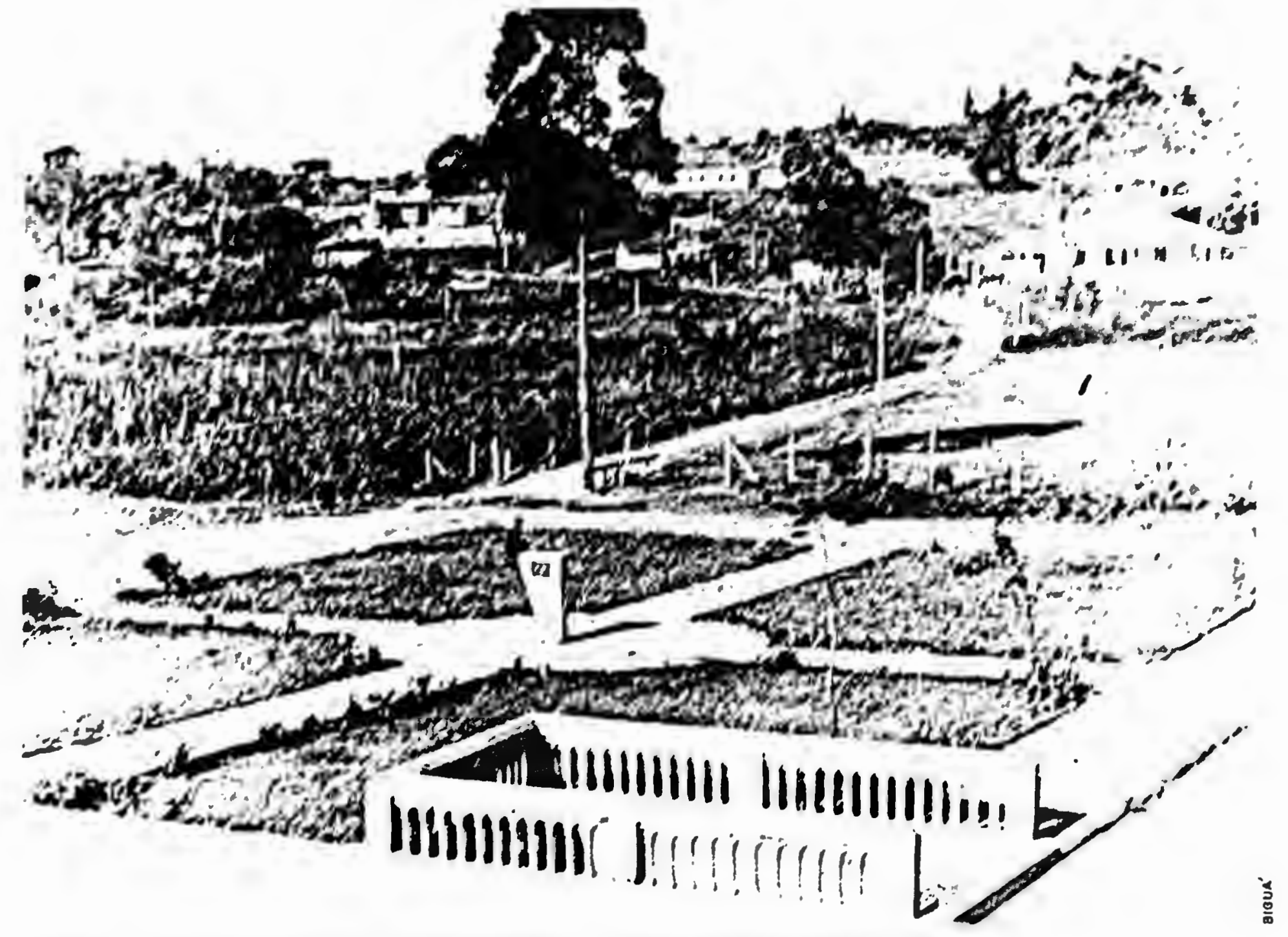


ponder ao antigo povoado"(11). Também ao norte da ferro via existia a capela construída a mando da mãe do proprie tário de Itaqui, e que fol restaurada por populares (12). Porēm, não atraíram a urbanlzação e foram demolidas na época da construção do acesso rodoviário à rodovia pres dente Castelo Branco. Dona Maria Martins Gōis residente em Jandira desde 1930 e proprietária da "Venda do Góis " (foto 6), assegura que a capela (foto 7) fol demollda pa ra se construir outra, mas a nova construção não se con cret1zou.

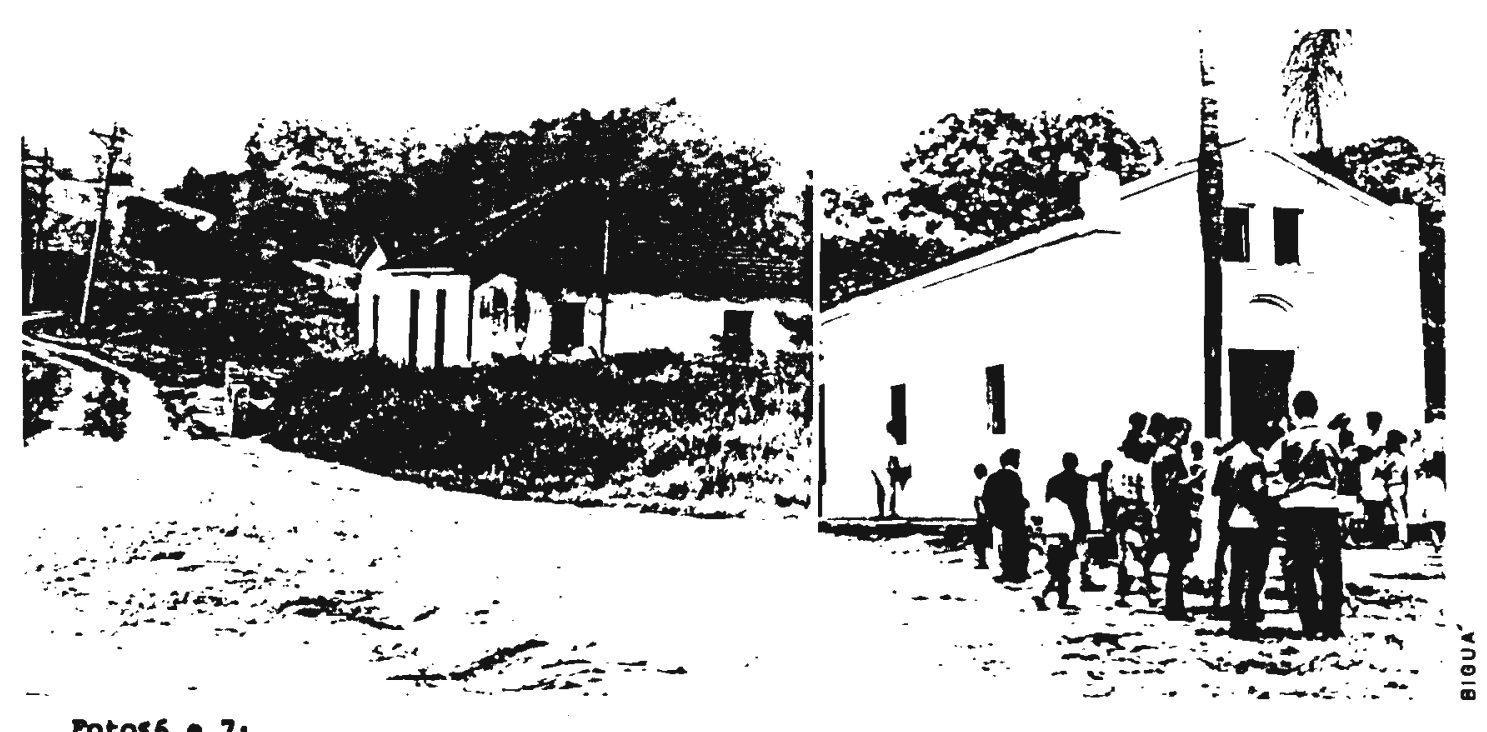

Fotos 6 71

68 Venda do Göls, estabelecimento comercial mals antlgo de Jandira, fundada em 1936. 7. Capela Bon Jesus de Itaguí.

(11) Juergen Richard IAANGENBUCH, A Estruturaçāo da Gran de Săo Paulo. P. 104

(12) Salnt-Hilaire $(p .203)$ ao falar do sitlo de Itaqui re feria-se à capela: "A mãe do proprietário de Itaqué fol quem, apesar de muito pobre, fez construir a grande capela existente perto desta fazenda (...) . Essa senhora, querendo assegurar, tanto quanto pos sIvel, a duraçăo da capela, fez ao morrer, o legado de uma pastagem, para com o seu rendimento, garan tir a conservação e manutenção da mesma. Construi $\bar{r}$ igrejas era, na época, a obra reputada como de mais agrado a Deus, a que, em tal sentido, sobrepunha-se a todas as outras". 
Em 1948, o pequeno núcleo urbano (foto 8) foi trans formado em distrito (13) e, em 1950 atingiu a categoria de sub-prefeltura do município de Cotia, apresentando , porém, uma infra-estrutura deficlente,segundo depoimento do Sr. José Nunes de Camargo, então nomeado fiscal muntcipal.

A época da partilha, o Sítıo das Palmeiras possuía a casa-sede, uma casa para operārio e um salão para esco la. Já por volta de 1949-1950, o Sr. José Nunes de Camar go, diz ter encontrado mais ou menos trinta casas e " uns do1s armazéns: A maior parte dos terrenos eram comprados por pessoas da capital, Interessadas na valorização. Os preços alnda eram balxos e a propaganda já se utilizava de folhetos.

Nas palavras do Sr. José Albino Pereira, uma parte da herança dos flihos de Concelção Sammartino fol prime1 ramente negoclada com João e José zolzak, sendo revendida depols ao próprio J.A. Pereira. Com a experiêncla que trazia de suas atividades imobiliārias exercidas na cap 1 tal, este senhor organizou o loteamento conhecido por Jardim Novo Horizonte, localizado na parte da cldade onde atualmente se encontram a Praça das Palmeiras e ruas com nomes de pássaros. Mas outros corretores de 1móvels . tambēm de São Paulo, foram se interessando pela região e lotearam o remanescente das áreas que pertenclam aos her detros.

(13) Lei n8 233 de 24 de dezembro de 1948. 


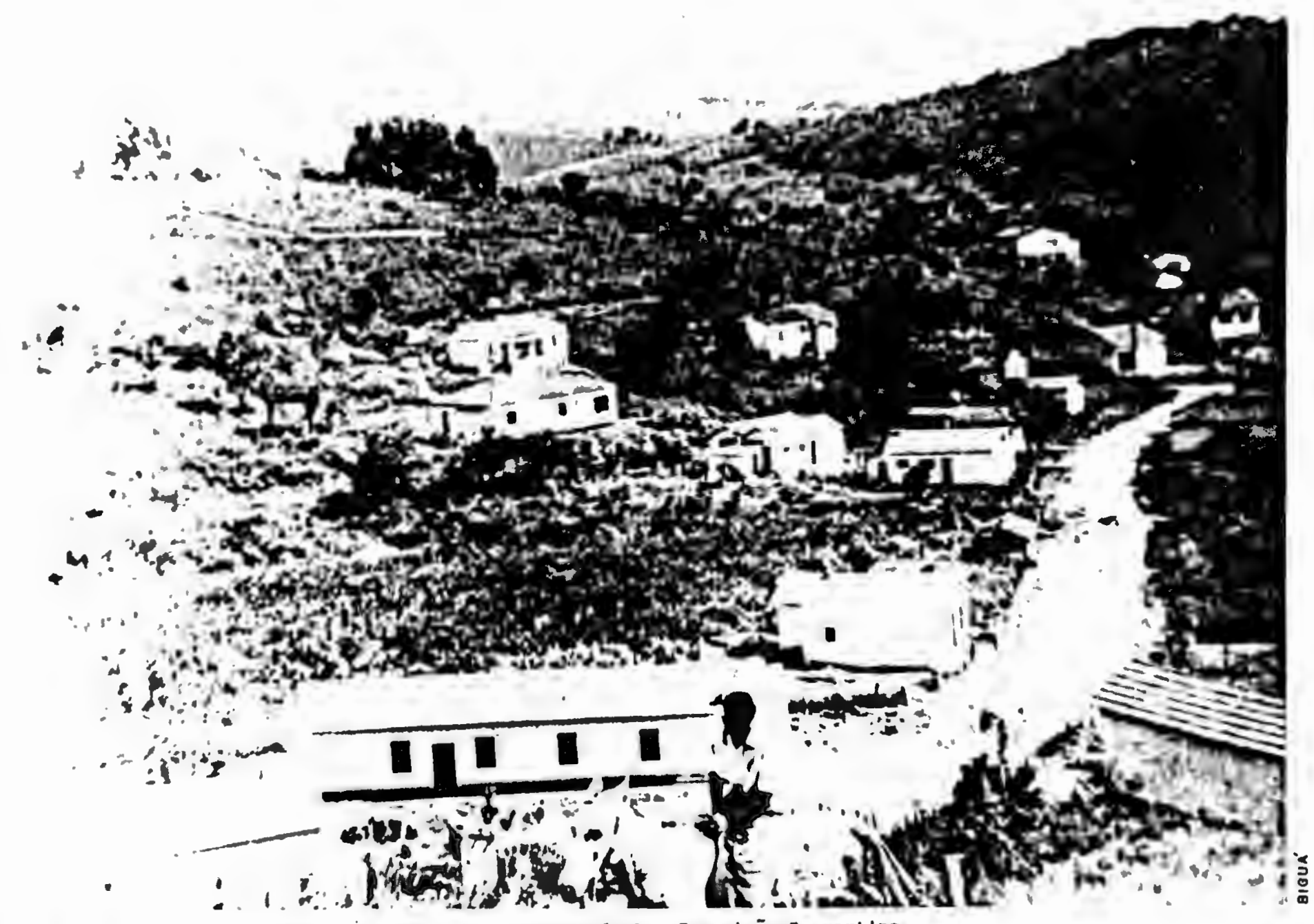

Foto 8: V1ata parcial de Jandira, em 1948. Aspecto da Av. Concelção Sarmartino. 
Pelo Censo de 1950, Jandira apresentava o seguinte quadro populacional:

\begin{tabular}{|c|c|c|c|c|c|c|c|c|}
\hline \multicolumn{3}{|c|}{ T T A I S } & \multicolumn{2}{c|}{$\begin{array}{l}\text { QUADRO } \\
\text { URBANO }\end{array}$} & \multicolumn{2}{c|}{$\begin{array}{l}\text { QUADRO } \\
\text { SUBURBANO }\end{array}$} & \multicolumn{2}{c|}{$\begin{array}{l}\text { QUADRO } \\
\text { RURAL }\end{array}$} \\
\hline tal & homens & mulhs. & homens & mulhs. & homens & mulhs & homens & mulhs. \\
\hline 475 & 787 & 688 & 137 & 140 & 194 & 159 & 456 & 389 \\
\hline
\end{tabular}

snte: Censo Demográfico IBGE

A especulação imobiliāria prosseguia, com as 1mob1 liárias (geralmente pertencentes a empresārios de $\mathrm{S}$. Pau 10) fazendo publicidade através de folhetos e fornecimen to de alguns materiais de construção, como tijolos e telhas, a titulo de "brinde". Tal politica talvez tenha sido instituida para atrair pessoas de poucas posses que necessariamente habitariam a região, diante de um possI vel desinteresse em comprar terreno para valorização . fato multo discutível diante da precária realidade urba nIstica.

A Lel no 20 de 10 de abril de 1956 (14), delimita - perimetro urbano da sede do distrito de Jandira (fig. VIII).

(14) Art.18-Fica delimitado o perimetro urbano da sede do distrito de Jandira, deste Municipio, com as seguintes divisas: Começa no Ventilador do Pereira e segue em Iinha reta pela divisa do Sr. Fernando Pessoa, na extensão de 258 metros, até encontrar o córrego ali existente, sem no me e dal à direita em reta, com a extensão de 246 metros, até a rua das Andorinhas; segue por ela até o fim e dal à direita, em reta de 342 metros, pela Adutora de Águas, até encontrar a rua Dr. Waldemar Albano, e dal segue pela mes ma até encontrar a Estrada de Ferro Sorocabana; dâ à dI refta, pela linha de ferro, até o marco n.1-onde defrontā o corrego sem nome, desse ponto sobe pelo dito córrego a té a estrada de rodagem de Baruert; segue à esquerda pelà dita estrada até defronte a Av. São Paulo e dal, a rumo direito pela avenida São Paulo, até o ponto de partida . fechado este perímetro com a área de 436.875 metros qua drados".

Arto 28-Esta Lel entrará em vigor na data de sua publicação, revogadas as disposições em contrário. 


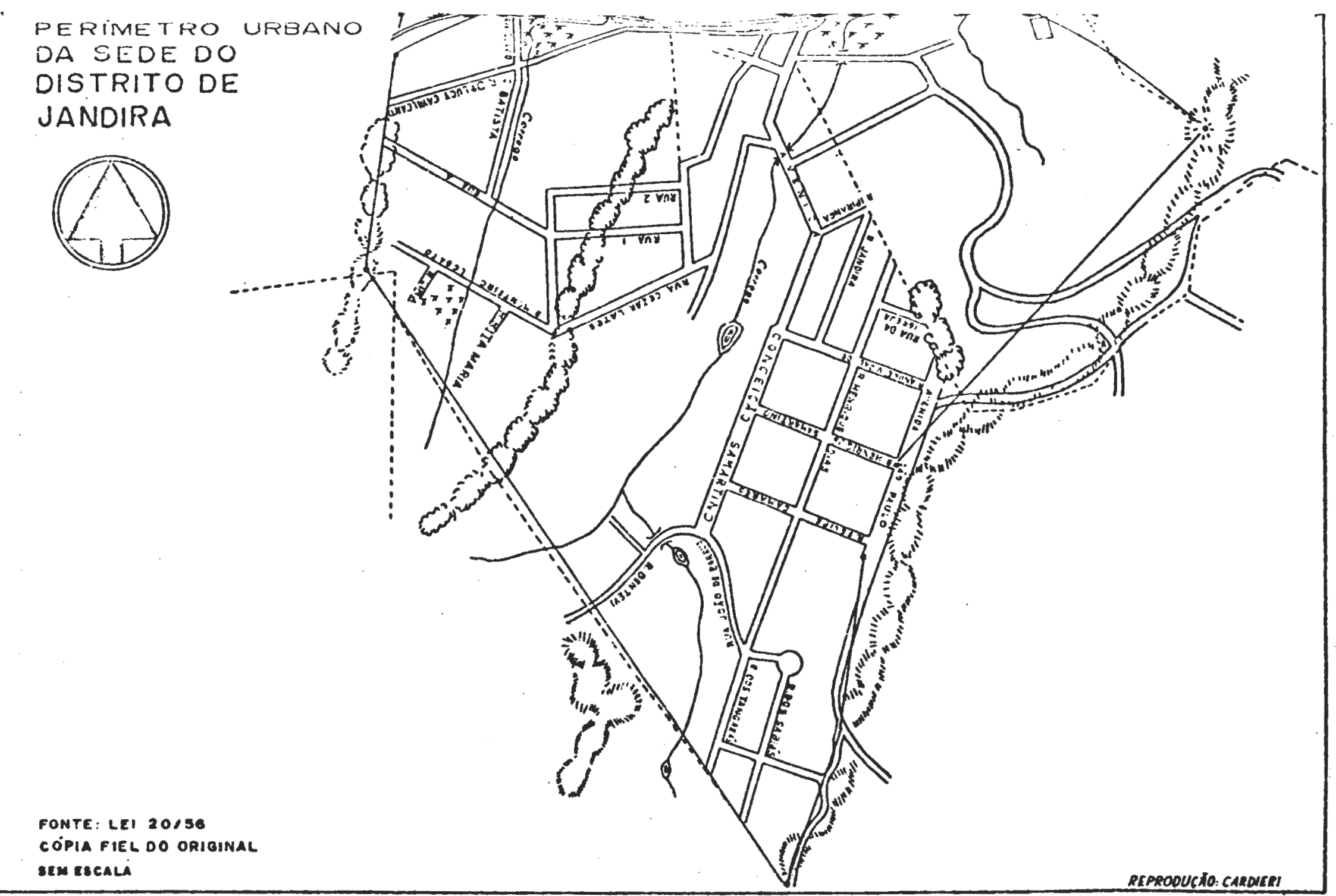

FIo.VIII 
- Frigorifico Jandira S/A (foto 9), primeiro passo no pro cesso de industrialização do municipio, fol inaugurado em 1961, com a vinda de Anielo Gragnano (proveniente de Ara çatuba), que o construiu nas proximidades da Estrada de Ferro Sorocabana, (atual FEPASA) com o objetivo evidente de utilizar-se da ferrovia para o transporte de matéria prima. Essa localização deve-se também à proximidade do mercado consumidor, no caso, são Paulo (16).

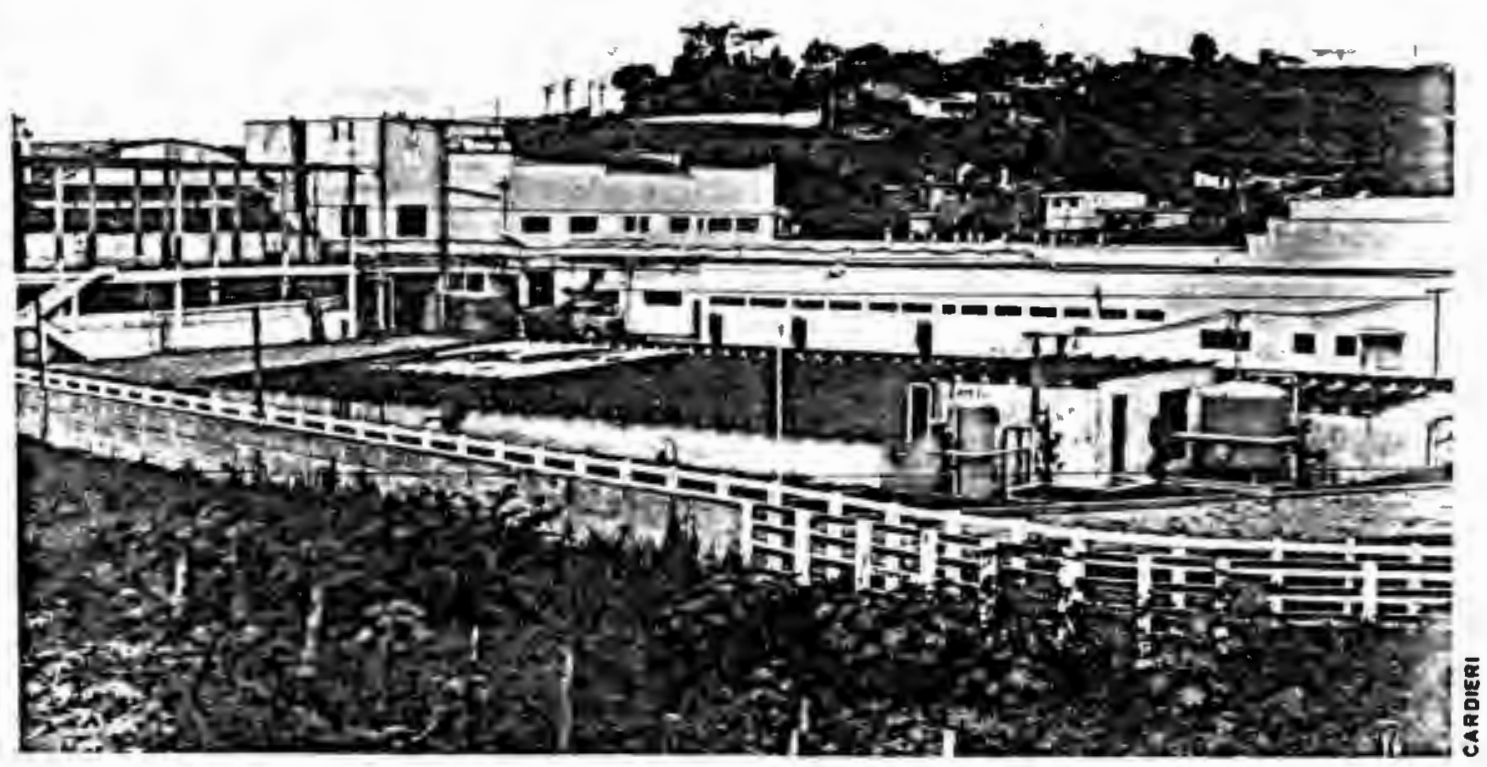

Foto 22 FrigorIf10o Jand1ra $8 / A$

Até 1970, o gado vinha do Interior do Estado, por trem, desembarcava em Itapevi e chegava a Jandira por rodovia. Nesse ano, a direção da ferrovia autorizou a construção de um ramal que atingia o interior das dependências do frigorifico.

(16) Vide Pasquale PETRONE - São Paulo no século XX - In "A c1 dade de são Paulo" - vol. II - 1958 - p.108 - Segundo es te autor: "Abrindo novas áreas industrials na periferia da cldade em busca de terrenos de menor preço e de maiores espaços, condicionada quase sempre pela proximidade das vias fërreas, expansão industrial vem concorrendo para a formação e o fortalecimento do que poderemos chamar Grande São Paulo, a exemplo do que se verifica com as malores aglomerações urbanas do planeta" 
Evitava-se, assim, que a bolada se dispersasse ou mesmo "estou rasse" pela cidade, como aconteceu por vezes, quando os an1 mals lam a pé dos vagões até a făbrica Daí a necessidade tem porária do transporte rodoviário desde Itapevi.

Data Igualmente de 1961 a Instalação de uma me talúrgica de pequeno porte,que vem se expandindo lentamente visto que apenas em 1973 teve suas instalaçōes ampliadas, com a aquisição de sede própria.

Alēm da mão-de-obra a ausência de outros atrą tivos locais era um entrave para a fixação das indústrias. Con sequentemente, o terceiro estabelecimento de importância, a Pedreira Jandira (foto 10), distante da ferrovia, fol implanta da quatro anos depois (1965), mas apenas porque a matéria prí na oferecia condições favorávels a sua exploração,voltada para
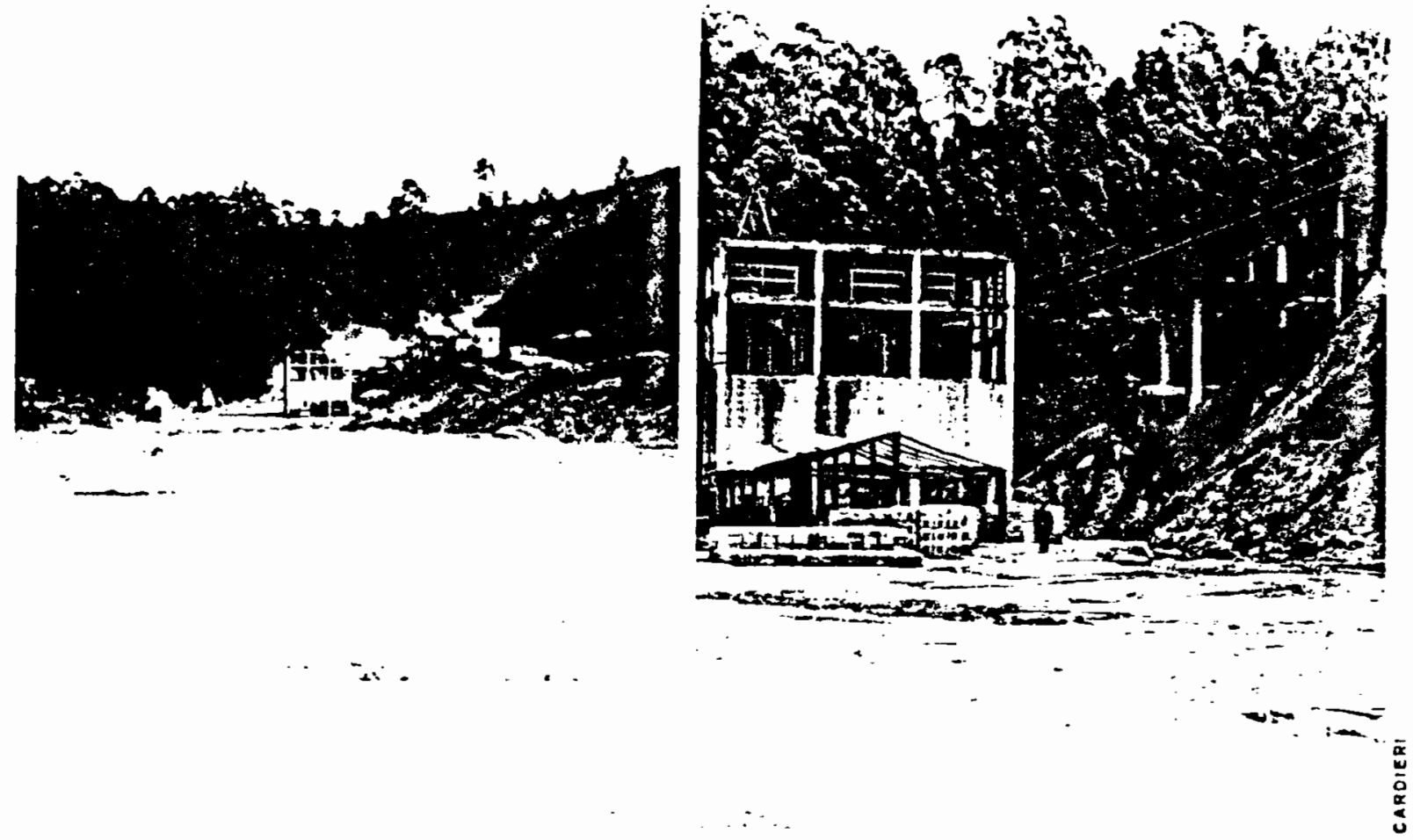

Foto 10: $A$ esquerda Instalaçōes da Pedreira Jandira Ltda.

A direita, fábrica de blocos, ocupando o espaco contiguo à pedreira desativada. 
obtenção de material de construção. Tal fato, afinal,aliado à proximidade de qrande mercado consumidor, velo concorrer para - aproveitamento da mão-de-obra local. As olarias existentes são de pequeno porte, mas sobressaem-se pelo nümero de estabe lecimentos. Os depósitos argilosos também eram explorados . principalmente nas várzeas, sob a forma de olarias, a seu tụ no presentes na oferta de material de construção, sendo uma constante na paisagem.

Predominando no municlpio indústrias que se en quadram, pelo IBGE, no gênero de produtos minerais não metál1 cos, caracterizadas pela reduzida ocupação de força de traba lho, a maior porcentagem da população ativa continua sendo ca nalizada para municíplos da Grande são paulo,notadamente são Paulo e Osasco.

Atē o final da década de 60 , o quadro Indus trial pratıcamente não se modificou. A edição da lel municí pal no $239 / 70$. que dispõe sobre incentivos ao crescimento In dustrial, a principlo não surtiu muito efelto. Entretanto, pouco mals tarde, as facllidades oferecidas pelo diploma legal e a construção (1974) da via de acesso Jandira-Rodovia Presí dente Castelo Branco fizeram com que o municiplo passasse a ser procurado com frequência pelas Indústrias em expansão. Con forme dados do PIS/SENAI, em 1975 existiam doze indústrias instaladas. Em levantamento efetuado junto à Prefeitura Mun cipal (julho de 1979), verificou-se que já se encontram em fun cionamento vinte e cinco indústrias e ofto estão em fase de construção. Tals fatos e os já citados por P. Petrone resul taram no crescimento acelerado ocorrido nos últimos cinco anos. No Quadro I, tem-se a relação das indústrlas, com os respect 1 vos endereços. 
QUADRO I

RELAÇÃO DE INDOSTRIAS INSTALADAS NO MUNICIPIO DE JANDIRA EM FUNCIONAMENTO

1 . Frigorifico Jandira S/A - Km. 31,5 da FEPASA - Jandira-SP.

2 . Pedreira Jandira Ltda. - Chãcara Santa Rosa - Jandira-SP. (17)

3 . Hércules S/A Equipamentos Industrials-Via de acesso à Cas tello Branco

4 Imprimé - Indústrias de Malhas S/A - Via de acesso à Cas tello Branco

5 . Premo - Pré-Moldados de Artef. de Cimento Ltda. - Via de acesso à C. Branco

6 . Ind. e Com. de Sebos e Adubos de Jandira Ltda. -Estrada de Barueri/Itapevi

7. Pirell1 - Cia. Industrial Brasileira - Via de acesso Jand 1 ra à C. Branco

8 . S.A. de Materiais Elētricos (SAME)-Via de acesso Jandira à C. Branco

9 . Formil Quimica Ltda. - Estr. Velha de Itu-Vila Márcia. Jan dira

10. Conspel - Empresas Reunidas Ltda. Rua Waldemar Albano, 50 Jandira

11. Indústria de Massas Alimenticias "Diplomata" - Rua Bartolo meu de Gusmão

12. Agrolite S/A - Cimento e Amianto - Via de acesso Jandira a C. Branco

13. Argamassas Quartzolit S/A - Vla de acesso Jandira à C.Bran co

(17) Consegulu-se este dado Junto à Prefeitura Municipal em ju lho de 1979. Em visita ao local, em outubro, verificou-se que a Pedrelra não mals se encontra em funclonamento des de fevereiro/79. A partir de então uma fábrica de b1ō cos encontra-se em atividade em seu lugar. 
14. Açotécnica - Microfusão de Aços Especiais S/A - Via de a cesso Jandira/C. Branco

15. Bardella Borriello Eletromecânica S/A-Estrada de Vila Már cia - Jandira

16. Indústria Mecânica Paulista S/A - Via de acesso Jandira à C. Branco

17. Farex Ind. e Com. de Máquinas Ltda.via de acesso Jandira à C. Branco.

18. Laminação Pásqua Ltda.-Via de acesso Jandira à C. Branco

19. Trefilação de Aço "Mercūrio" S/A - Estrada Velha de Itu, ne 1000 - Jandira

20. Friozem-Armazens Frigorificos - Via de acesso Jandira à C. Branco

21. Cemmi - Caldeiraria, Estr.Mec. e Montagens Ind. - Rua El1 V. Cesar, 325

22. S.E.T. - Serviços e Equipamentos Técnicos S/A - Rod. C. Branco - $\mathrm{Km} 32$

23. Construtora Buzollin S/A - Estr. Velha de Itu

24. Ind. e Com. de Plásticos Samurai Ltda. Rua Angelo Airoldi, 100

25. Mongobel - Ind. e Com. de Móveis Ltda. - Rua Waldemar Alba no

\section{EM CONSTRUÇÃO}

26. Ind. de Oleos Carbonnel - Estrada Velha de Itu

27. Da Serra $\mathrm{S} / \mathrm{A}$ - Via de acesso Jandira à C. Branco

28. Ind. Textil T. Gabriel - Rod. Castello Branco - Km 32

29. Ind. e Com. de Papéis "Stryna" - Estrada Velha de Itu

30. Pilão - Aços e Refinadores Ltda. - Rod. Cast.Branco Km 32

31. B.R.M. - Ind. Brasileira de Rolamentos e Mancais - Estrada Velha de Itu

32. São Pedro - Vidros e Espelhos Ltda. Via Barueri/Itapevi-JD Gabriela

33. Ind. de Coz Florence Ltda. Rua Antonio Bardella

Fonte:Prefeitura Municipal de Jandira - 1979 
Talvez por conta dos impostos a serem pagos pelas futuras indústrias em instalação na época (1974) em que este trabalho começou a ser feito, destruiu-se uma praça pública para a construção da fonte luminosa, que não fun cionava por absoluta falta de água e que atualmente já se encontra demolida. Isto demonstra o despreparo adminis trativo que caracteriza tantos responsáveis por municI pios.

\subsection{Loteamentos atuais}

A ocupação residenclal dos loteamentos vem se processando de forma multo esparsa,dificultando sobremaneira o alcan ce da infra-estrutura urbana. Este fato pode ser notado principalmente em municipios de parcos recursos econôm 1 cos e na periferia de grandes concentrações urbanas, como é o caso de Jandira. E uma particularidade anômala, cita da como efeito negativo do método próprio utilizado pelas imobiliārias para parcelar e valorizar a terra. De fato, um "novo loteamento nunca era feito em continuidade Ime diata ao anterior, já provido de serviços públicos. Ao contrário, entre o novo loteamento e o último já equipado, delxava-se uma área de terra vazla, sem lotear. Completa do o novo loteamento, a linha de ônibus que o serviria se ria, necessariamente, um prolongamento a partir do últí mo centro equipado. Quando estendida, a linha de ônibus passava pela área não loteada, trazendo-lhe lmediata va lor1zação" (18).

Rangel (1978) ao tratar do custo social da urbani zação, refere-se à mesma como sendo "uma operação onerosa, Implicando em pesados custos, tanto a longo, como, princi (18) - Paul SINGER e et al11-Recursos Humanos na Grande São Paulo - Vol. 1 - 1971 - p. 9 
palmente, a curto prazo. Segue-se que a polftica de urba nização deve ser felta à vista de uma cuidadosa anāilse custo/benefício" (19). Este fato não parece ser devidamen te considerado, uma vez que a abertura de novos loteamen: tos ocorre independentemente das necessidades do municipio, que se vê obrigado a arcar com pesados ônus para dar à po pulação uma condição minima de nivel de vida. Por outro lado, os lotes foram e são vendidos a individuos de balxa renda, visando exclusivamente o lucro dos loteadores. o comprador, sem condiçōes financelras para escolha de uma área já urbanizada, tinha em mente o ldeal primeiro de a brigar-se e fugir do aluguel, sem preocupar-se com as ben feitorias que acreditava fossem decorrentes de uma efetiva ocupação, salvo a condição de proximidade de. melo de trang porte que é a ligação entre a residência e o trabalho (20).

Por tratar-se de uma ārea cuja morfologia apresen ta desniveis topográficos consideráveis, em termos de as sentamento urbano, o traçado das ruas fol por vezes adapta do ao terreno, apresentando-se ora de forma aparentemente caōtica, ora em tabuleiros de xadrez,ocupando indistintamen te encostas, topos e fundos de vales. Assim, os terrenos variam muito de forma e tamanho, predominando testadas de cinco e sete metros, e comprimentos diversos, mas normal mente atingindo vinte metros e mais.

- processo ut1lizado para a construção da casa tam bém varia segundo as possibilidades financelras da familla e mesmo o relacionamento de amizade que ela tenha ou não

(19) - Ignãcio Mourão RANGEL - Questão Agrária e Agricul tura - 1978 - inédito - p.10

(20) - Fernando Henrique CARDOSO e outros in "Recursos Hu manos na Grande são Paulo", - p.8 tratando desse as̄ sunto diz "o forte desejo de propriedade próprio dâ sociedade brasileira,e as instabilidades da Leide In quilinato durante a fase aguda do processo de expañ são da cidade levaram os habitantes da Grande são Paulo a colocar a propriedade da casa como fator prioritário de suas vidas". 
conseguido no bairro. O mais comum é a compra do terreno para posterior construção.

Atualmente, o mutirão é um meio muito difundido para construção de casa prōpria. A pesquisa domiciliar de 1976 atestou a validade desta afirmação para a área em eg tudo, com o levantamento dos diferentes meios utilizados para a construção das residências. Apurou-se que das cen to e setenta $(1008)$ familias inquiridas, apenas trinta , isto é, 17,658 compraram a casa pronta, vinte e uma (consti tuindo 12,358 do total) moram em casa alugada e duas famí lias, 1,178, em casa cedida. Comprovou-se, ainda, que cen to e quinze familias, correspondendo a 67,668 do total adquiriram o terreno para depois construirem aos poucos. Nesse caso, o mutirão e o pedreiro contratado, com respec t1vamente 39,138 cada um sobre o total de casas construÍ das, despontaram como formas preferidas, sendo que 21,748 das casas foram construídas pelo próprio proprietário.

Um número significativo de familias, 46,088 , logra ram adquirir o material de construção mediante pagamento à vista; as que o adquiriram a prazo o fizeram,geralmente, na prōpria loja de material para construção: fol o caso de 91,528 das familias que tiveram que apelar para esse meio. Houve apenas um caso em que o material fol financiado pela Caixa Econōmica, ao passo que quatro familias recorreram ao emprēstimo bancário.

Segundo informaçōes colhidas nas olarias, em razão do menor preço de compra, facilidade e rentabilidade na a plicação, o bloco de concreto vem substituindo com sucesso - tradicional tijolo de argila, o que explica, em parte - gradativo desaparecimento das olarias (foto 11). 


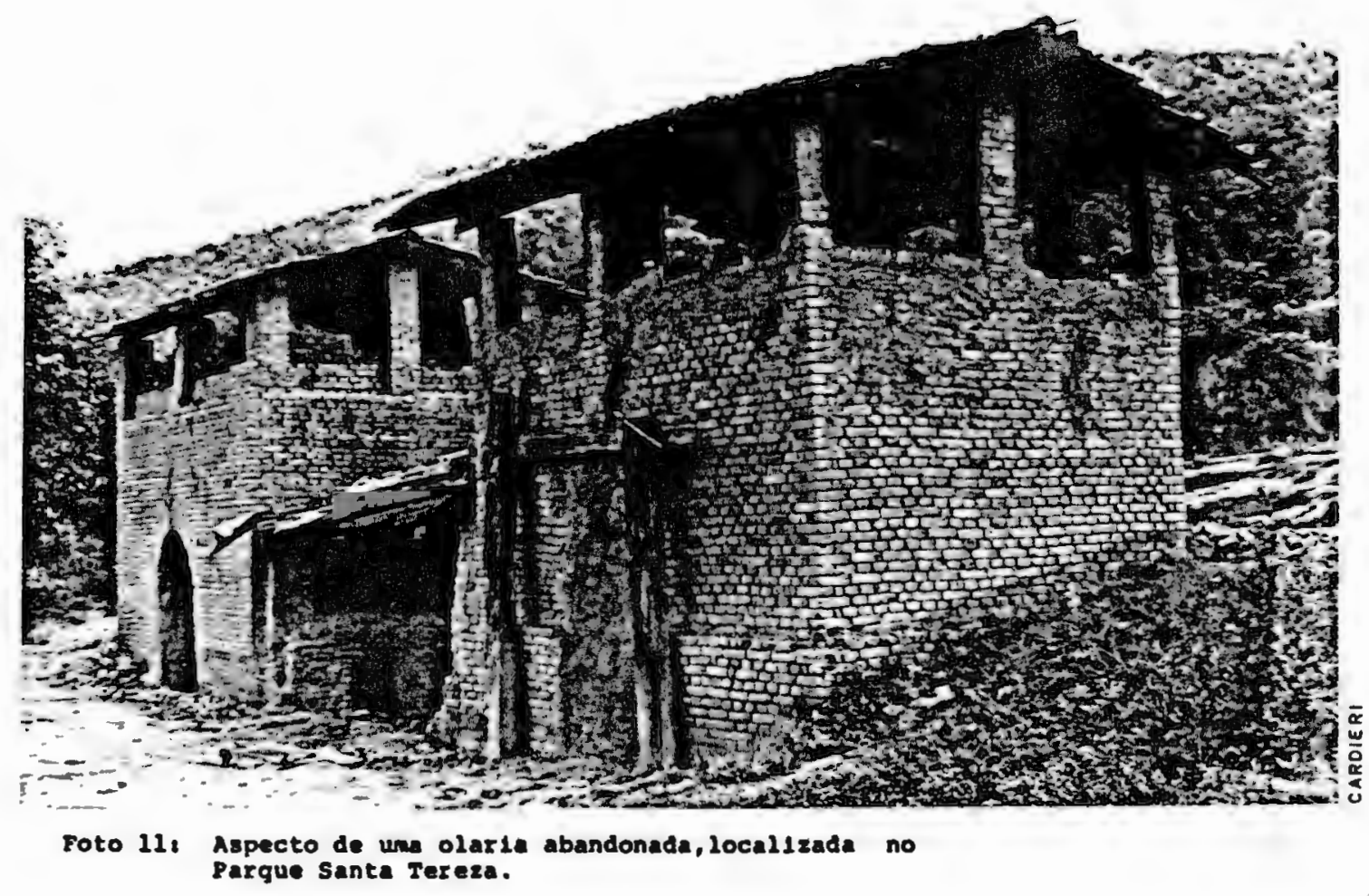

A condição econōmica da população só permite que a casa seja feita por etapas. Assim, no ato da aquisição do terreno, geralmente "ganha-se" como brinde a quantidade suficiente de tijolos e telhas para iniciar a construção. Isso aconteceu em loteamentos novos, principalmente na fa se de lançamento. Muitas vezes a 1déla de ampliação, ou mesmo construção da casa na frente do quintal, fica ape nas no sonho (foto 12). 


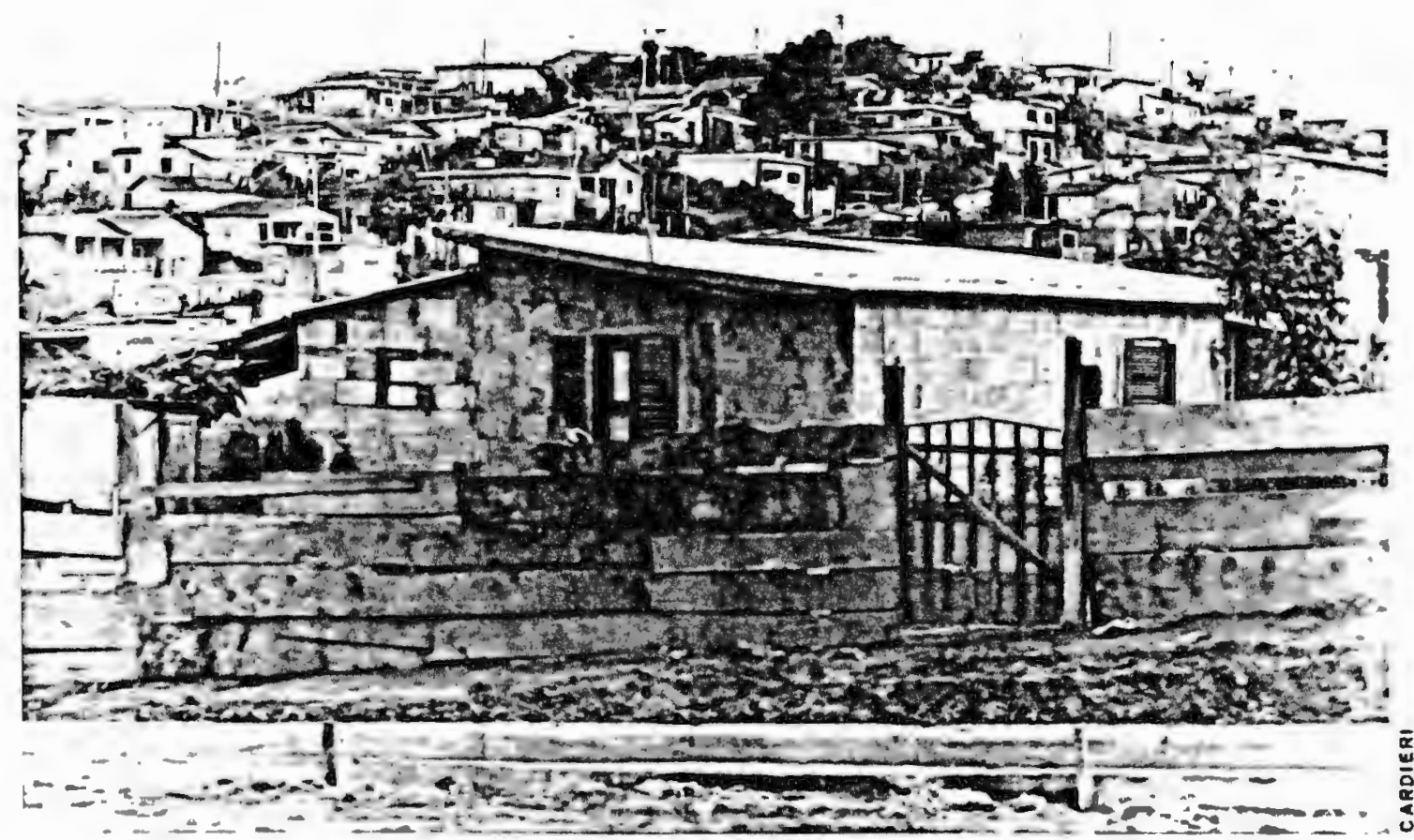

Foto 128 Casas deste t1po sio una constante na paisagem jandirense.

Estas residênclas, alēn de seu tamanho Infimo, coñ 'sideradas as necessidades dos habitantes, são deficientes no que se refere às condiçōes minimas de higiene e confor to. Por um lado, 1sto acontece porque o proprietário tem esperança de construir uma casa melhor em futuro não mu1 to remoto. Por outro, não dispōe, nem quer dispor caso possa fazê-lo, de dinhelro para aplicar na casa atual,que julga ser provisōrla. Donde a Inexistência, ou precarie dade, das instalaçōes sanitárias. A falta de água encana da é outro fato concorrente para as péssimas condições h1 glênicas. E interessante destacar o número de cômodos , geralmente balxo, e o excessivo número de pessoás nele abrigadas. Conforme Questionärio Domiclliar 1974, de um total de 779 famillas, 6,168 moravam em apenas un cômodo, que servia ao mesmo tempo de sala, quarto,cozinha e ba 
nheiro (banho). Encontrou-se uma familia de 8 pessoas mo rando nessas condiçōes; 20,418 residiam em dols cômodos,ut 1 lizando apenas um deles como quarto. Uma familia de doze e outra de treze pessoas residem em casas desse tipo.

Algumas ruas localizadas próximas ao centro da cida de, como a William Wadel e Valdemar Albano, possuem casas malores e mals confortáveis (foto 13).

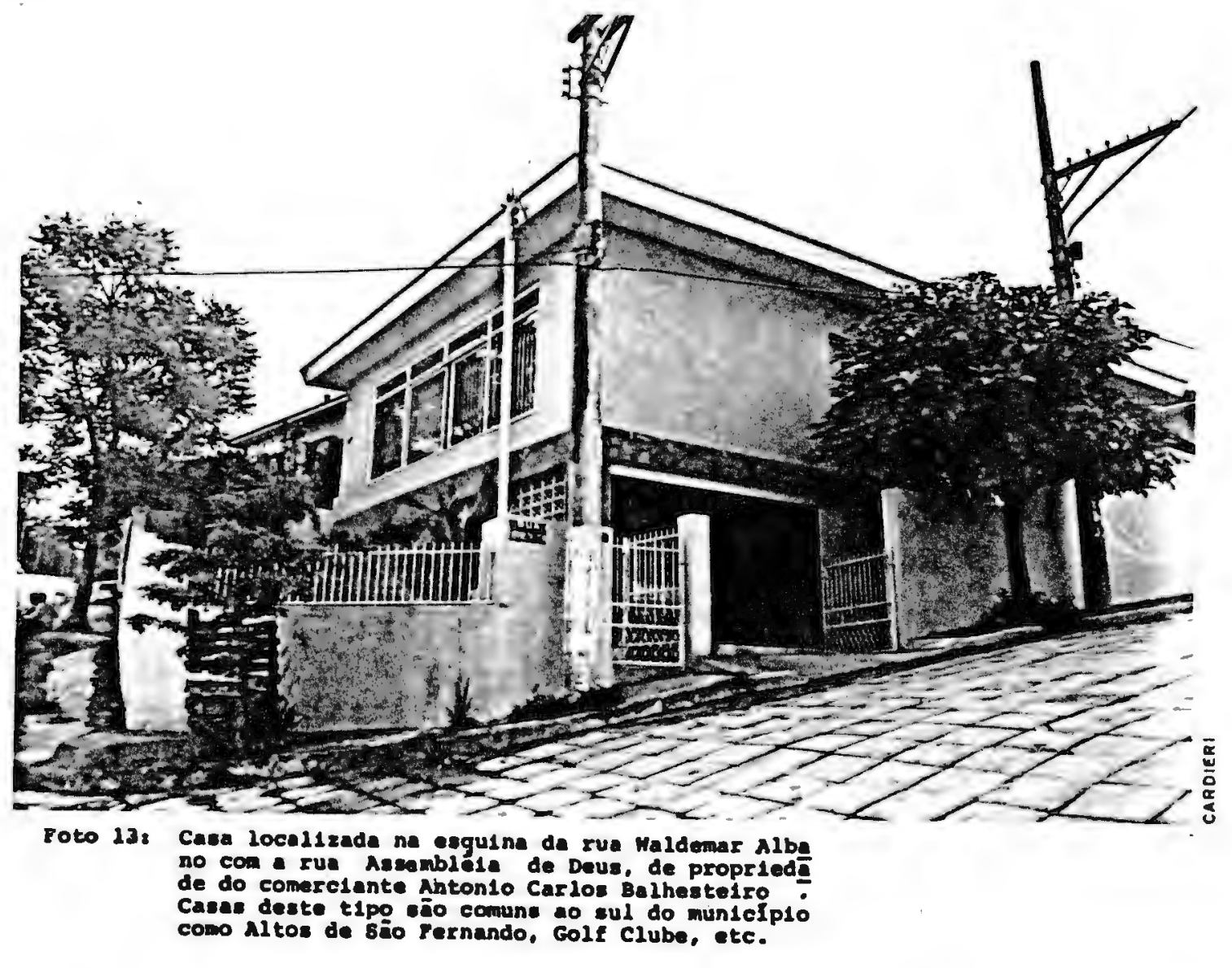

o alto Indice de casa prōpria $(85,318)$ na amostragem, verificado neste trabalho,demonstra a preocupação de "segu rança",pols constitu1, segundo Jorge wilhelm "o simbolo de garantia, face à insegurança do emprego,desvalorização da moeda e das Incógnitas apresentadas pela multiplicidade de opçōes novas. E por $18 s 0$ que, apesar da penúría e baixo nI vel econômico, as periferias pobres das grandes cidades a presentam o maior Indice de casa própria" (21).

(2I) - Jorge WILHEIM-Urbanismo do subdesenvolvimento, 1969 p. 46 . 
Até 1957, teve moroso crescimento o processo de ur banização.

Em 1958, houve como que un surto de novos loteamen tos, para calr novamente a partir de 1959. Novo impulso, malor que o primeiro se fez notar em 1966, estabilizando se com um cresclmento moderado dal para a frente.

Os loteamentos foram mapeados segundo o período de implantação. A carta "Jandira: Fases de crescimento urba no", vide fig. IX, pode ser utilizada também como uma planta Indice, uma vez que os loteamentos encontram-se nu merados segundo a ordem cronológica de implantação, como no quadro II, abaixo:

Quadro II - Loteamentos por ano de Implantação

\begin{tabular}{|c|c|c|}
\hline ANO & $\begin{array}{l}\text { N9 DO } \\
\text { LOTEAMENTO }\end{array}$ & NOME DO LOTEAMENTO \\
\hline 1944 & 1 & Vila Anita Costa I \\
\hline 1945 a 1950 & 2 & V1la Esmeralda \\
\hline & 3 & Vila Diogo Balhesteiro \\
\hline & 4 & Vila Anita Costa III \\
\hline & 5 & Vila Rancho Alegre \\
\hline 1951 a 1955 & 6 & Jardim MarI11a \\
\hline & 7 & Jardim das Rosas \\
\hline 1956 a 1968 & 8 & Jardim Novo Horizonte \\
\hline & 9 & V1la D.Clemencia \\
\hline & 10 & V1la Aurora \\
\hline & 11 & Vila Eunice \\
\hline & 12 & Loteamento Tozz1 \\
\hline & 13 & Recrelo Santa Rosa \\
\hline & 14 & Vila Santo Antonio \\
\hline & 15 & Jardlm Masé \\
\hline & 16 & Vila CecIl1a \\
\hline & 17 & Parque J.M.C. \\
\hline
\end{tabular}




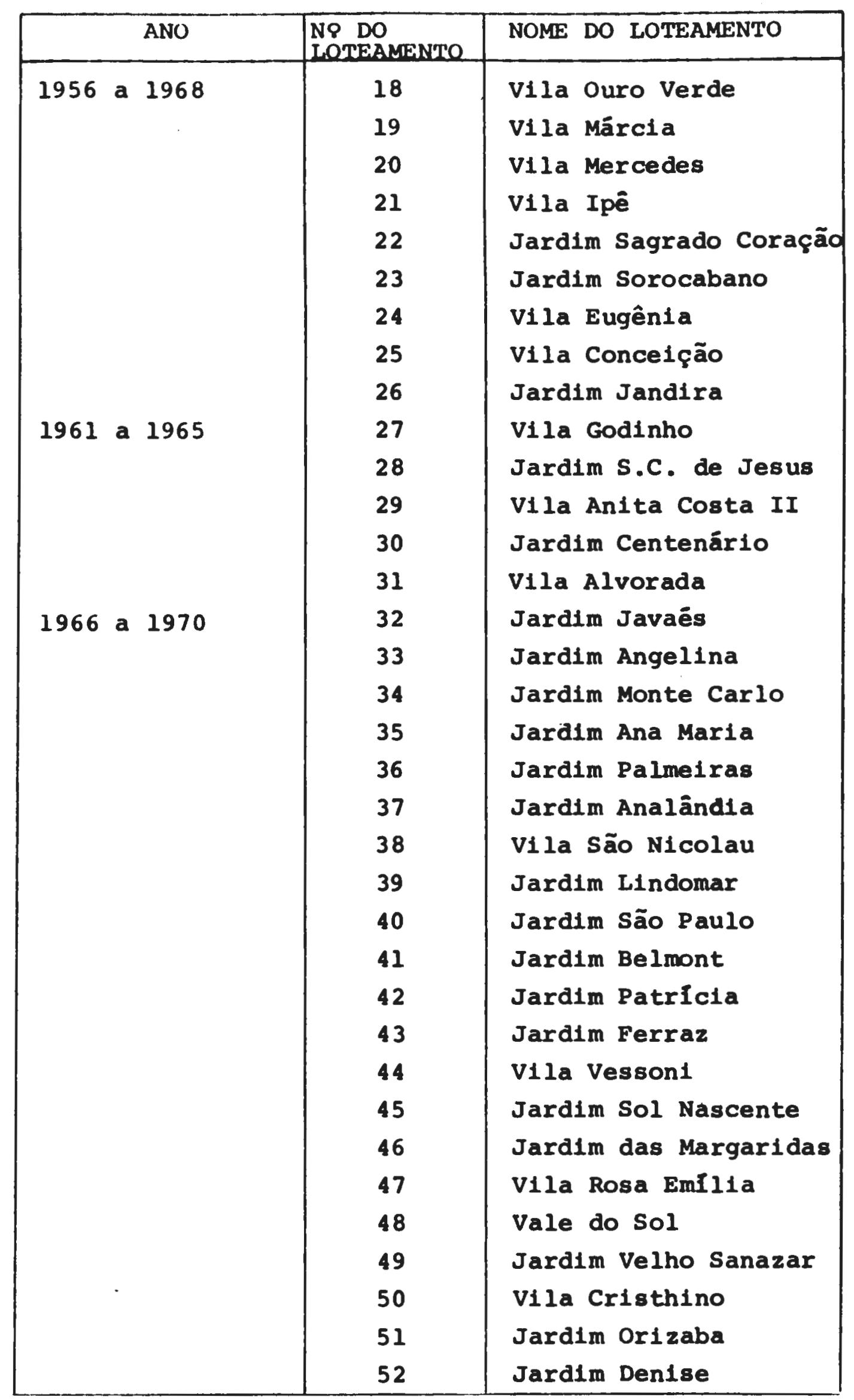




\begin{tabular}{|c|c|c|}
\hline ANO & $\begin{array}{l}\text { NO DO } \\
\text { LOTEAMENTO }\end{array}$ & NOME DO LOTEAMENTO \\
\hline \multirow{12}{*}{1971 a 1975} & 53 & Jardim Brotinho \\
\hline & 54 & Vila Mackenzie \\
\hline & 55 & Vila Santa Rosa \\
\hline & 56 & Açude Velho \\
\hline & 57 & Altos do São Fernando \\
\hline & 58 & Parque Santa Tereza \\
\hline & 59 & V1la Pop1 \\
\hline & 60 & Sitio das Pitas \\
\hline & 61 & Vila Neusa \\
\hline & 62 & Vila Rolim \\
\hline & 63 & Vila Morri \\
\hline & 64 & Jardim Granja Alvorada \\
\hline \multirow[t]{10}{*}{1976 \& 1979} & 65 & Jardim BolIvia \\
\hline & 66 & Jardim Gabriela \\
\hline & 67 & Chācara N.S.Aparecida \\
\hline & 68 & Jardım N.S.de Fãtıma \\
\hline & 69 & Parque dos Lagos \\
\hline & 70 & Jardim Golf I \\
\hline & 71 & Jardim Golf II \\
\hline & 72 & Sulte Quebra Nozes \\
\hline & 73 & Chácaras do Peroba \\
\hline & 74 & O1teiros S.Fernando \\
\hline
\end{tabular}




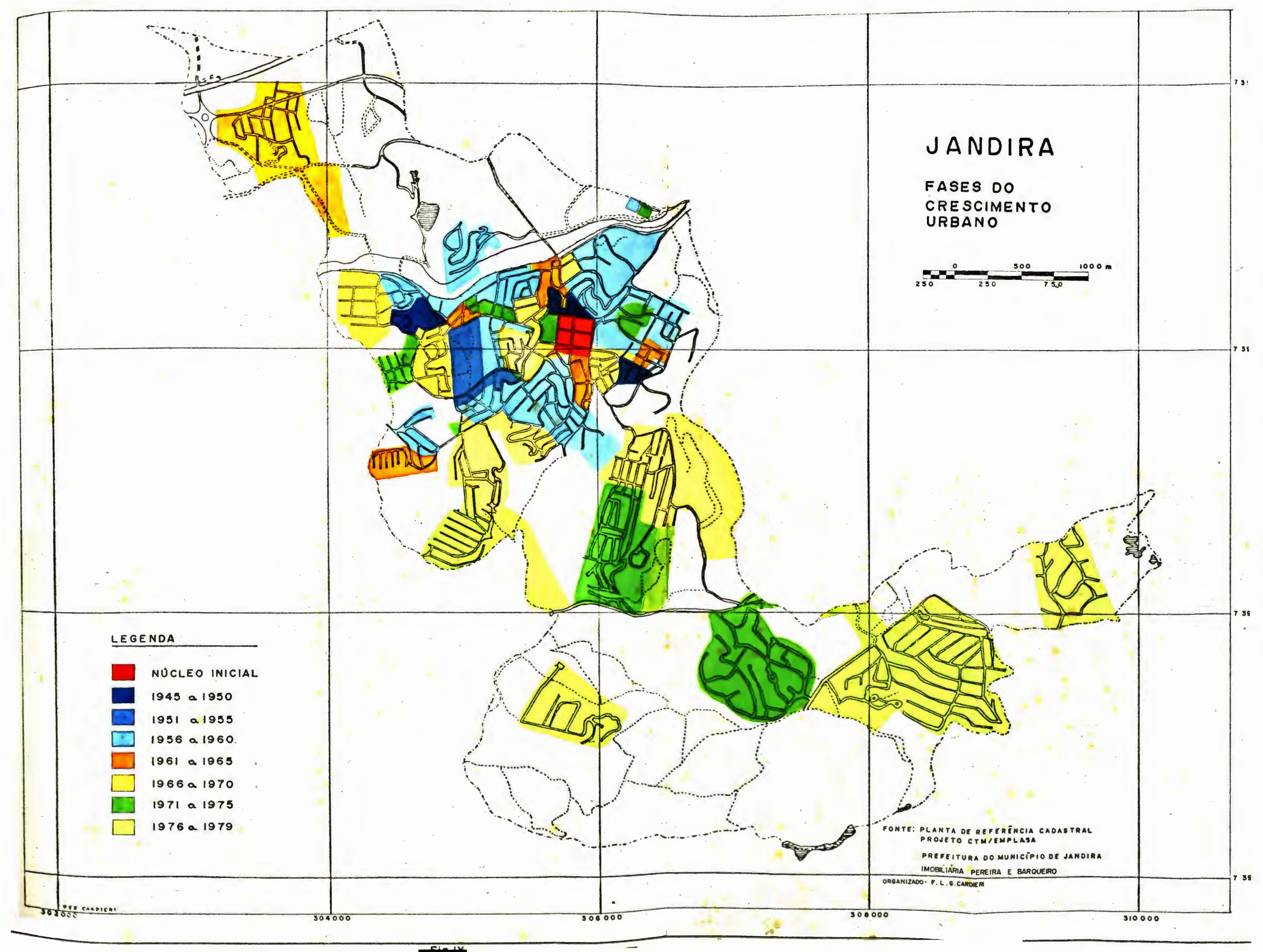




\subsection{Aspectos FÍsicos: Local1zaçāo e sItio}

o município de Jandira encontra-se no

Planalto

Atlântico (cf.Almelda, 1964), tendo altitudes compreen didas entre 722 m - na vārzea do rio são Joāo ou Barueri (f1g. X e XI) - e $864 \mathrm{~m}$, no limite com o municiplo de Itapevi, a Oeste. Inclui-se, mais especificamente, no Planalto Paulistano, o qual apresenta relevo suave (foto 14 e 15), cujas altitudes variam de $715 \mathrm{~m}$ a $900 \mathrm{~m}$ acima do nivel do mar (22).

As altitudes estão relacionadas à resistência das rochas, as quais são recobertas por uma camada de regoli to, proporcionando um relevo sem grande amplitude. Os ma tacões (foto 16) não são frequentes mas se fazem presen tes na årea (23).

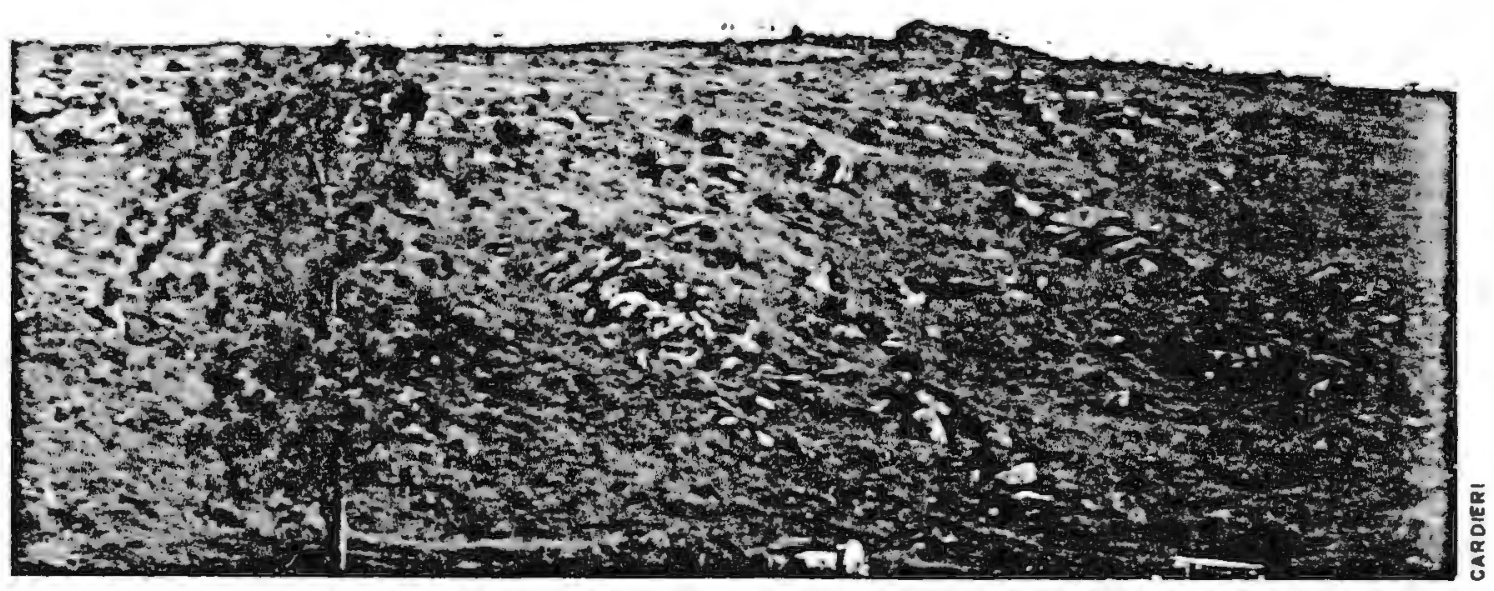

Foto 16, Matacöes local1zados no Jaxdlm Angalina.

Nos perfis topográficos constantes da figura XI , que cortam o muntcíplo de Oeste para Leste, é visivel o crescimento das altitudes à medida que se aproximando Pla nalto de Ibluna, confirmando o que se tem como certo: ser a altitude a principal diferença entre este e o planalto

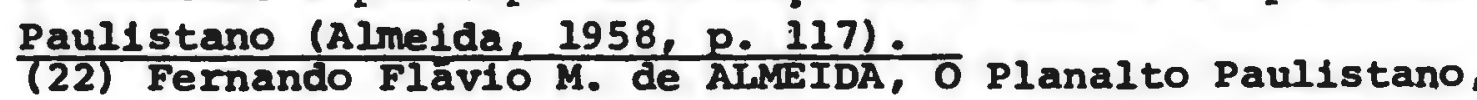
p. 115 .

(23) Fernando Flāvio M. de ALMEIDA,O Planalto Paulistano, p. 114 e 119 . 


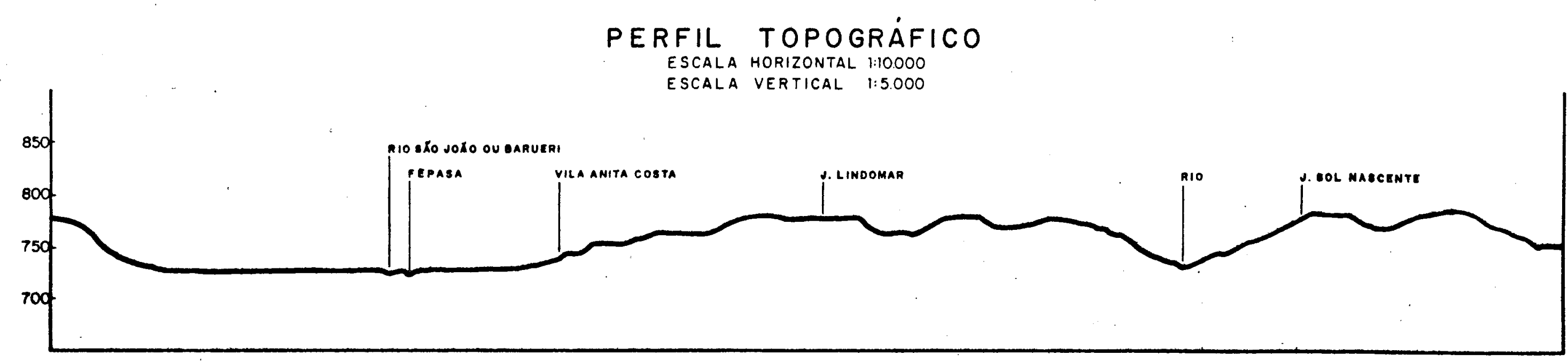

SECȦO A-A'

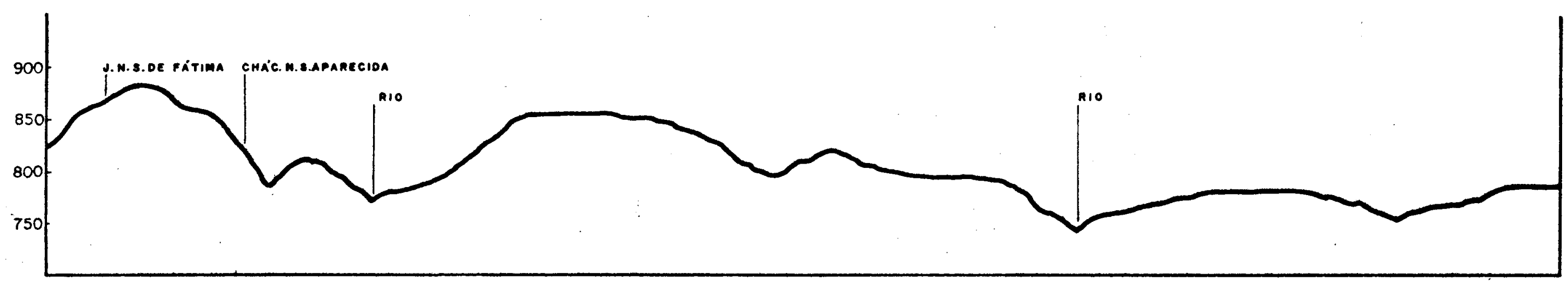

SECĀO B- B'

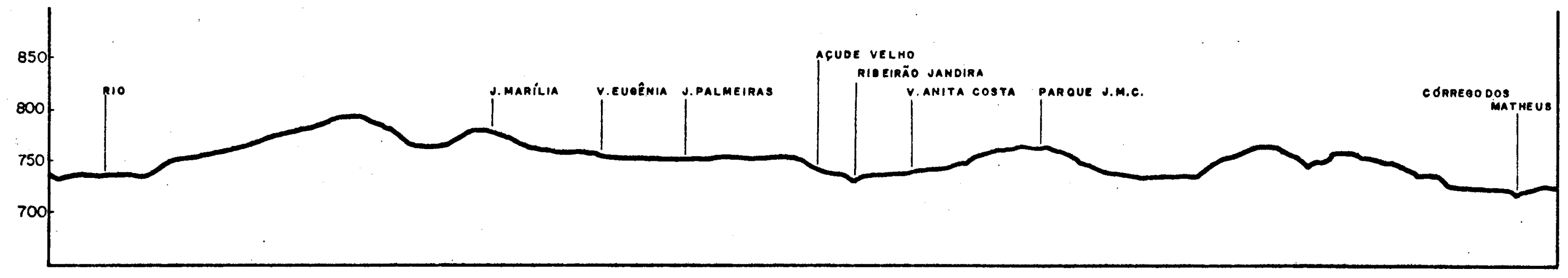

SECĀO C-C'

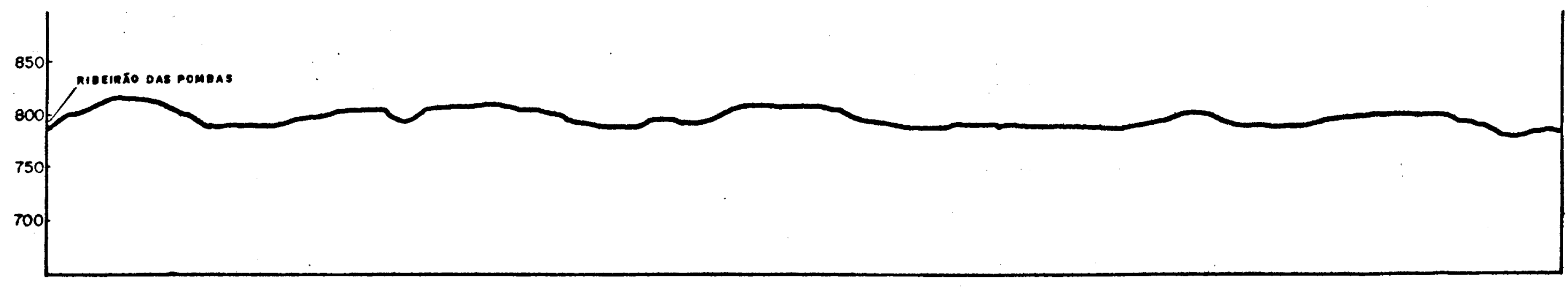

SEQĀO $D-D^{\prime}$

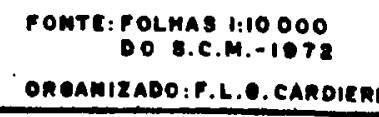

EIa YI

bericatame 

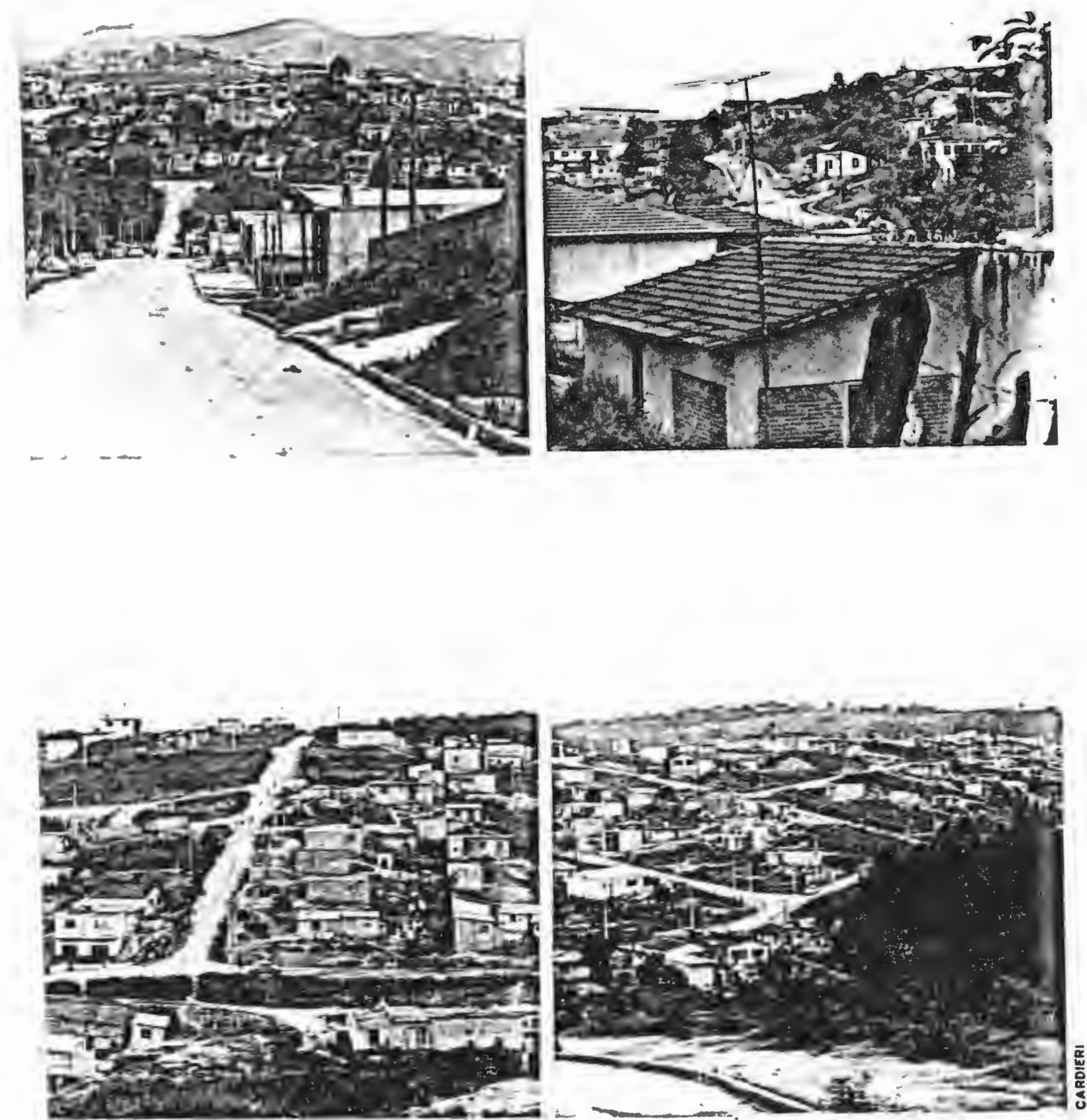

Foto 17 Mapectos de balrros Jandirenses:

$17 a$ - foto tomada da Av. Presidente Costa o 511 va en direçäo ao Jardlm Palmelras - Jardim Oxlzaba:

17b - Jardin Centenărio visto da rua Mil11aso Hade 218

17c - Jardim Mné vieto de Padreira Jandira e da rua Nicolat Maenaki. 
o primeiro loteamento assentou-se a meia encosta sem, no entanto, ter sido a morfologia fator imperativo nesta escolha.

A organização subsequente processou-se alheia a qualquer planejamento, não se atendo a empecilhos flsi cos, ocupando morros e encostas nem sempre favorâveis ao assentamento urbano. (foto 17 ).

A drenagem da ārea é construída pelos rios são João ou Barveri, Cotia e por alguns dos seus afluentes que nascem ou atravessam o municiplo. Esses rios, na es tação das chuvas, provocam enchentes, alagando,principal mente, a parte central do municipio. (foto 18).

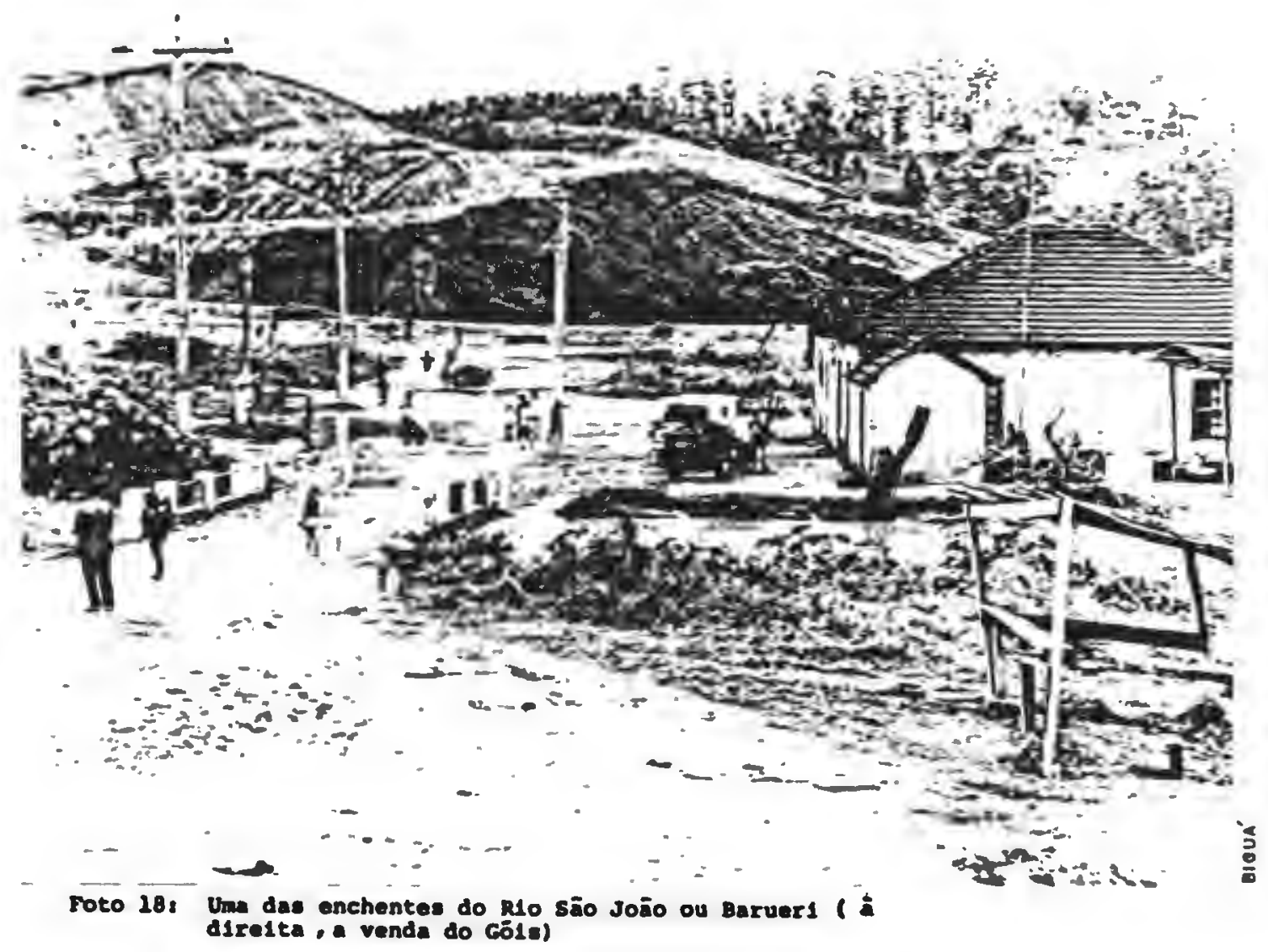


o rio São João ou Barueri apresenta-se com terra ços cortados a 718 - $730 \mathrm{~m}$, os qua1s, segundo Nakashıma (1978), correspondem à porção mais alargada de sua vár zea que se estende até Itapev1. "A malorla desses ter raços já sofreu remanejamento antrópico, tendo perdido parte de suas formações superficiais. Estão ocupadas por estradas de ferro, caminhos, campos de futebol, ins talaçōes industriais" (24).

o clima da área, como o de todo o Planalto Paulis tano, è marcado por uma estação chuvosa, com 65 a 80 \& dás chuvas anuals, nos meses da primavera, e uma estação seca, cujo total é inferior a 158, colncidindo com os meses de junho a agosto. Esta irregularidade constitul - traço marcante da climatologia regional. A temperatú ra médía anual é de $18,2^{\circ} \mathrm{C}$, sendo $21^{\circ} \mathrm{C}$ a médila do mês mals quente e $14,5^{\circ} \mathrm{C}$ a do mês mals frio (25).

\section{?.2. Uso do Solo}

Em 1958, Emilia Vlotti Costa (26) caracterizou a palsagem de Cotia como sendo tiplcamente agrária. Nes sa época, Jandira era un dos distritos daquele municipio.

Observando o mapeamento de uso do solo (Fig.XII) da área em estudo, quatro anos depois, percebe-se a Inexpressividade de āreas de cultura, aparecendo apenas aqui e acolá āreas pequenas e economicamente insignifi cantes. (24) Myriam da Silveira Re1s NAKASHIMA, Estudo' Topo
morfológico e de Formaçōes Superficials na Area de Baruer1 e Arredores, p.5.

(25) Secretaria dos Negócios Metropolitanos - Programa de Atendimento aos Municiplos - Relatório Jandira 77 p. 1 ....

(26) Emilia Viotti costa - A Cidade de São Paulo-V. IV - 1958 - p.113. 


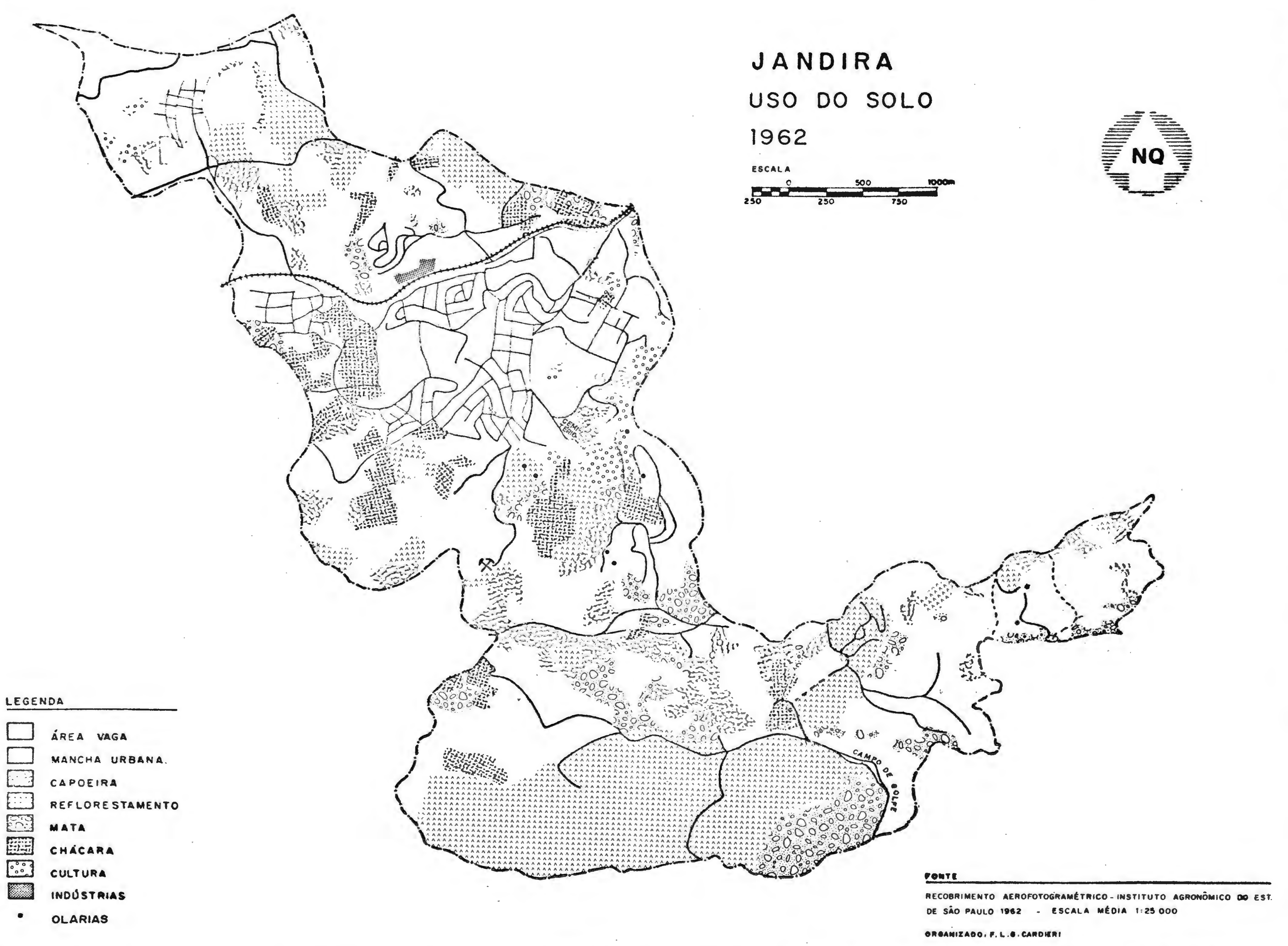


A intensa devastação a que esteve submetido o mu nicípio de Jandira e o irracional aproveitamento do solo (ou mesmo nenhum), resultaram numa paisagem com grandes vazios intermeados por chācaras, culturas, reflorestamen tos, capoeiras e capōes de mata, sobressalndo-se um małor, localizado junto ao lago que l1mita o municiplo com o de Cotıa, numa ārea de declividade acentuada.

Interessante frisar que os reflorestamentos exis tentes são de considerávels extensões, em relação à ārea do municipio $\left(22 \mathrm{Km}^{2}\right)$, sendo que, um deles pertence ao Estado, tendo sido preservado.

Com referência à Indústria extrativa observou-se que, em 1962, a pedreira já existia e vārias olarias achavam-se em funcionamento.

Classiflcaram-se como mata as äreas incluidas na definição da unEsCo (27). Outras, cuja cobertura vegetal não possuía tais caracteristicas, mas não chegava a carac terizar-se como cobertura arbustiva, foram classificadas como capoeira. Com o objetivo de verificar as modifica ções ocorridas no uso do solo, fizeram-se quatro mapea mentos, dentro da técnica de aerofotointerpretação, to mando-se por base o ano de 1962 e, a partir dal, dados de 1965, 1972 e 1977 (vide FIg. XIII, XIV e XV).

A observação do uso do solo, em 1965, sugere que as áreas de reflorestamento pré-existentes e as de mata praticamente permaneceram inalteradas desde 1962. As de cultura, Instaladas já em 1962, na várzea do cōrrego dos Matheus, a leste do município, não apresentaram modifica ções.

(27) - UNESCO - International Classification and Mapping of Vegetation - sêrie "Ecology and Conservation", no $6 ; 1973-\mathrm{p} .93$ 


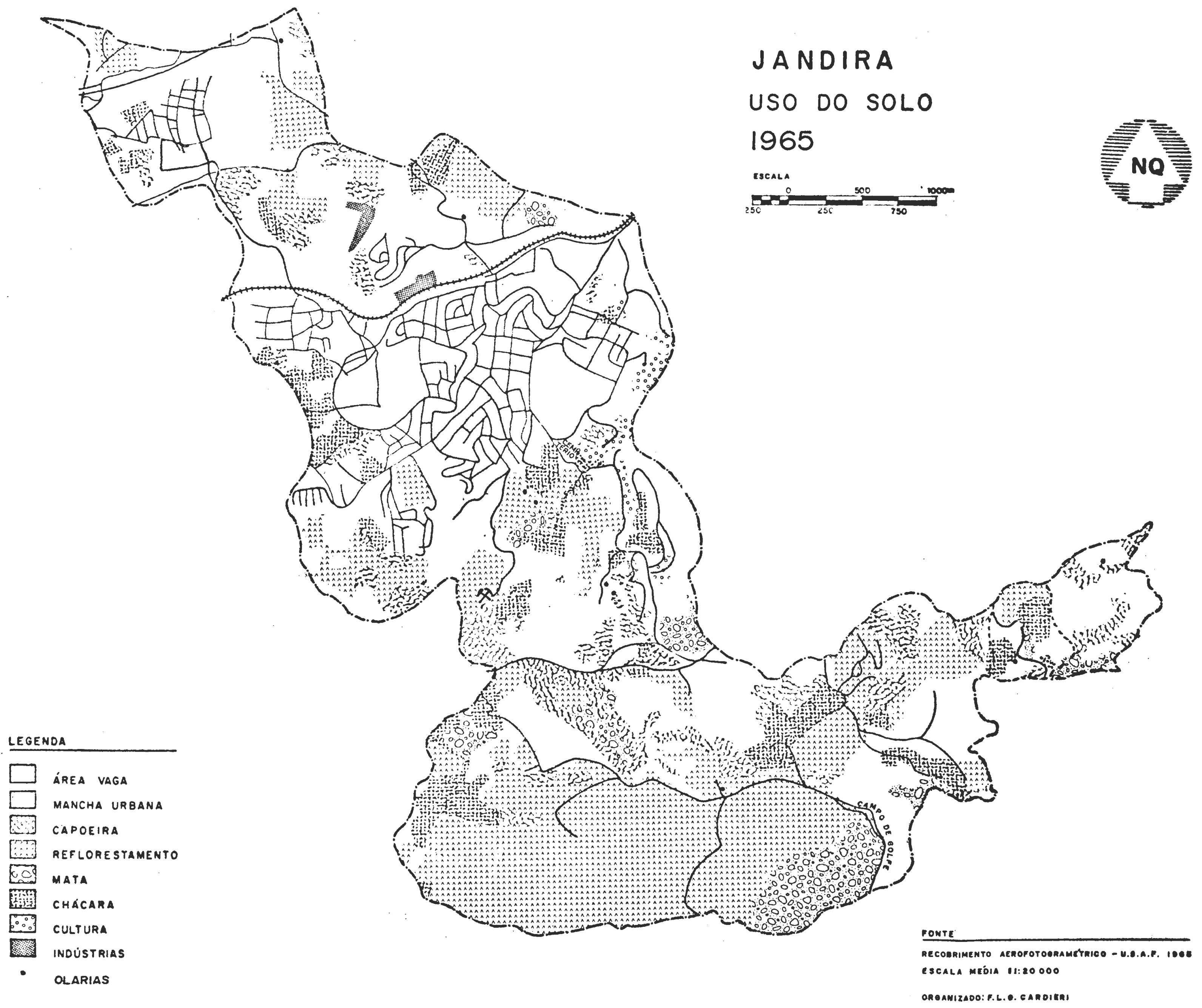




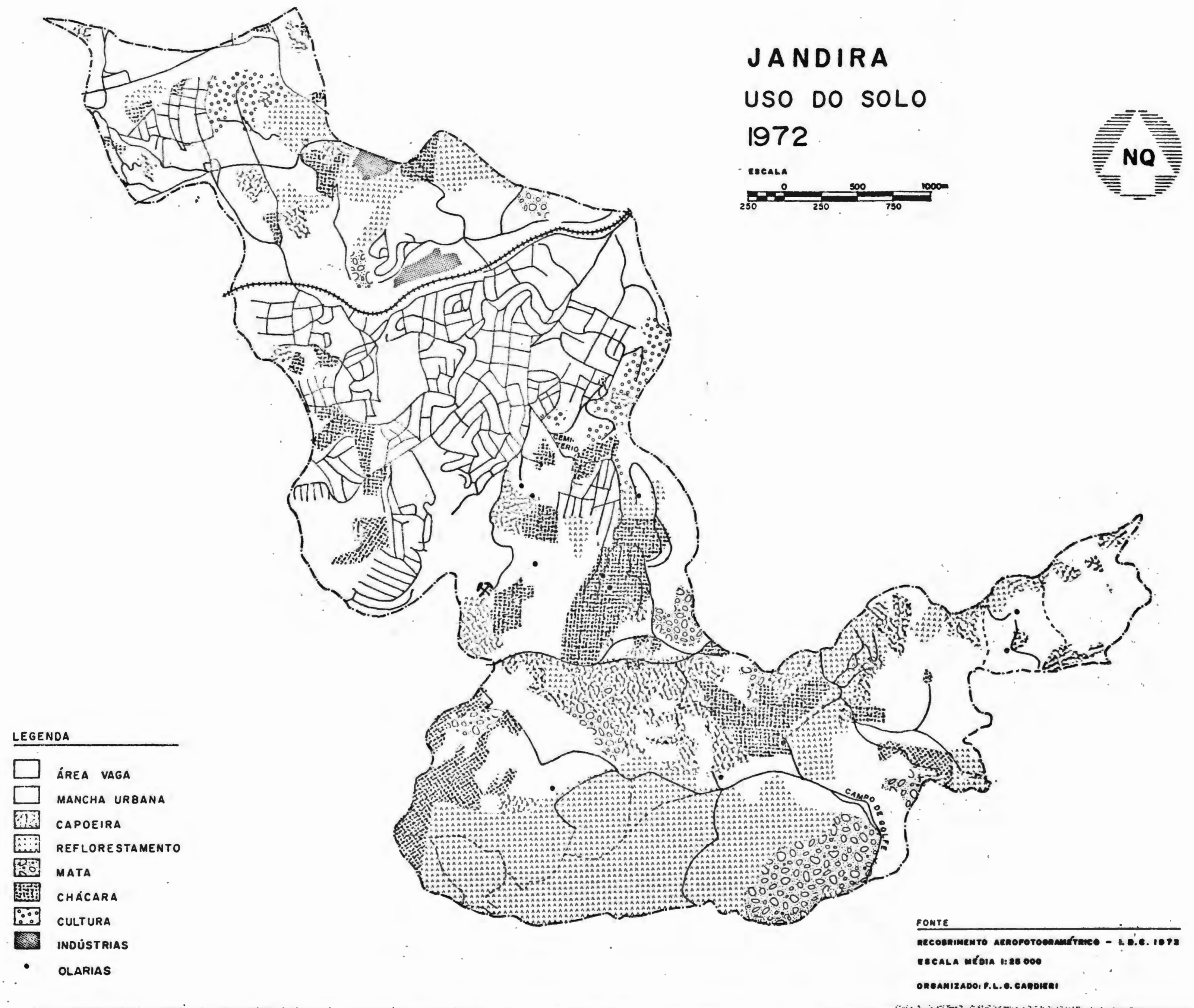




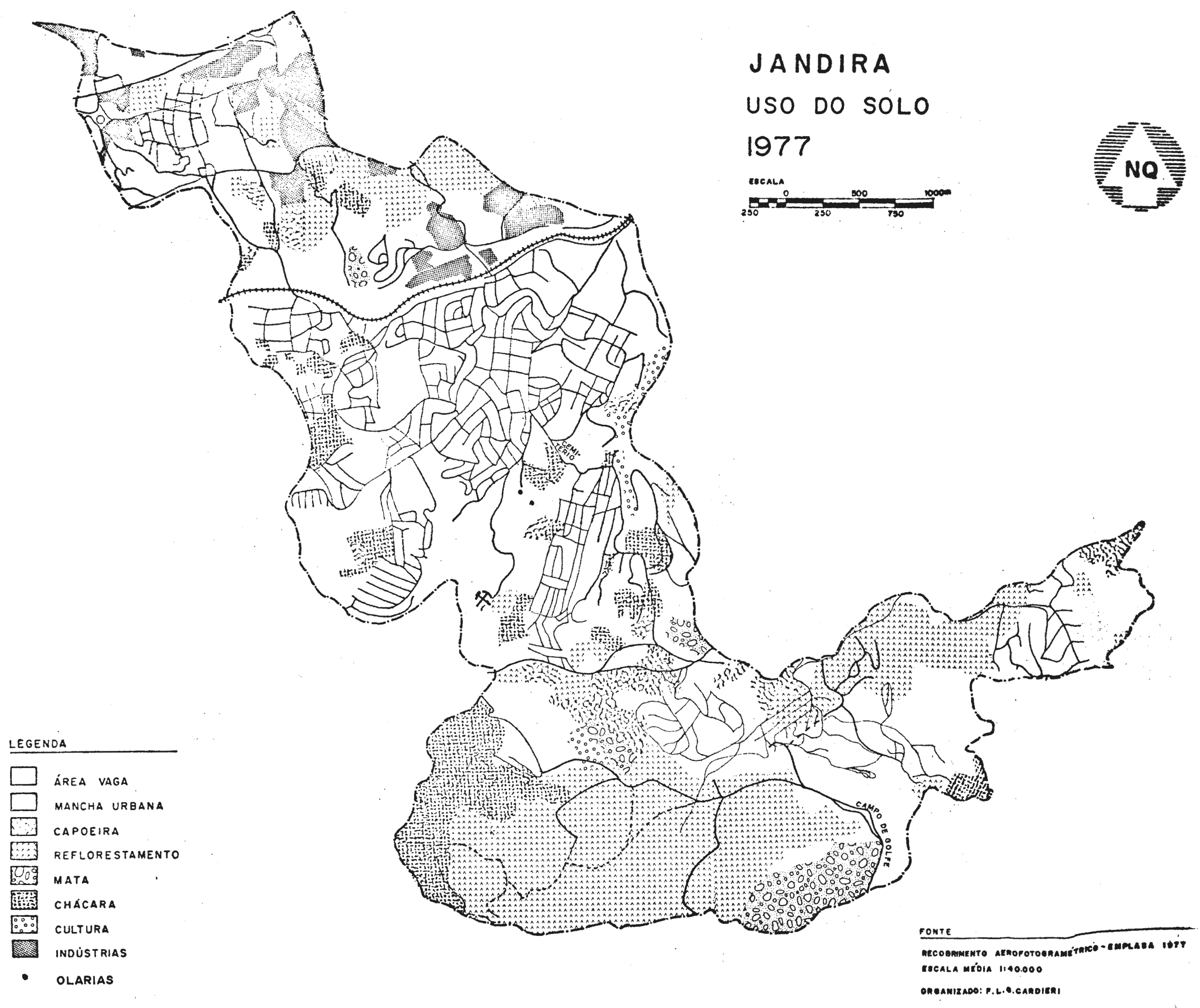


Os espaços foram cedendo lugar a novos refloresta mentos, chācaras e loteamentos urbanos em fase de abertụ ra, ou seja, apenas arruados.

Com referência à indústria extrativa já se observa a pedreira em funcionamento e o surgimento de novas ola rias.

Em 1972, algumas chācaras apareceram em loca1s an teriormente vagos ou ocupados por reflorestamentos, enquan to que outras foram absorvidas pela expansão urbana que também ocupou áreas vagas e de reflorestamento.

Próximo à rodovia Castelo Branco o local vago foi ocupado por horticultura (cultivo de flores).

Ao lado do frigorifico existente desde 1962 jā se pode ver espacialmente a presença de outra indüstria.

Amplas modificações ocorreram no uso do solo no quinqüênio 1972-1977.

o setor secundário como que explode espacialmente. As indústrias preferiram posicionar-se entre a ferrovia e a rodovia Pres. Castelo Branco, Influencladas pelo aces so a esta última. Até mesmo a ārea de cultura de flores, citada anteriormente, fol absorvida pelas atividades fa bris.

A evolução das ãreas de chãcaras, jã assinalada , continuou no mesmo ritmo, ressaltando-se que, na maioria dos casos, elas são usadas para o entretenimento de seus proprietārios, não habitantes do lugar, em geral.

Como um reflexo da "industrialização" está presen te uma aceleração do crescimento da ārea urbana com ten dênclas de expansão do centro para o sul e leste, em, for ma de um "L" maiūsculo. 
Uma análise global do uso do solo atual (1977) ré vela tendēncia a um zoneamento espontâneo, representado por três porções bem individualizadas. A primeira delas, que poderia ser chamada zona industrial, situa-se na por ção norte do município. A segunda, que concentra o setor comercial, de serviços e residencial, com predominância de loteamento popular, tem na ferrovia o limite com a zo na industrial. A estrada de Itapevi è o limite natural ao sul, entre a segunda zona e a terceira, esta represen tada por loteamentos com caracteristicas tais que os tor nam exclusivos para classes de renda mais alta.

Dentro desta última zona, chamam a atenção as chã caras por seu crescimento progressivo nos últimos anos . podendo chegar, futuramente, a constituir-se numa quarta zona.

.3. Função Urbana

A exemplo de muitas cldades interioranas, a área de comércio e serviços, que neste trabalho denominou-se segunda zona, está disposta em forma linear, no caso, ao longo da Av. Concelção Sammartino (vide fig. XVI, fotos 19 e 20).

Vê-se que as residênclas que ainda se localizam neste corredor, muito lentamente vão sendo substituidas por essas atividades, como resultado da tendência natural de fuga da população de zona estritamente comercial.

Comércio e serviços, bastante incipientes, não dî versificados, são fatores que caracterizam Jandira como cidade-dormitório (28).

(28) O Diagnóstico Municipal de JandIra 77, p.7 refere-se ao fato: - "Assim, em 1970, Jandira classificara-se como "cidade-dormitório", jā que não tinha base eco nômica especializada". 


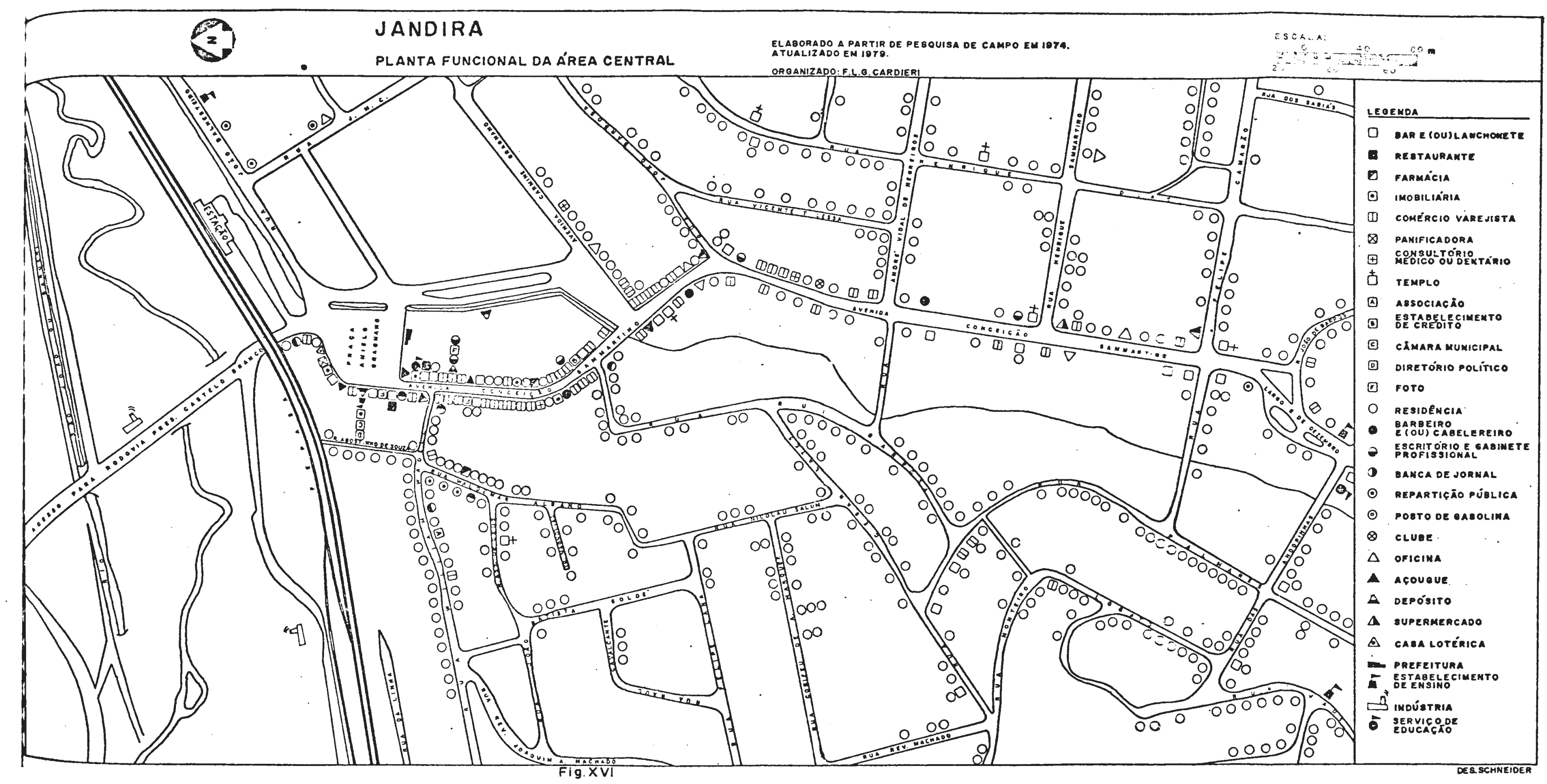



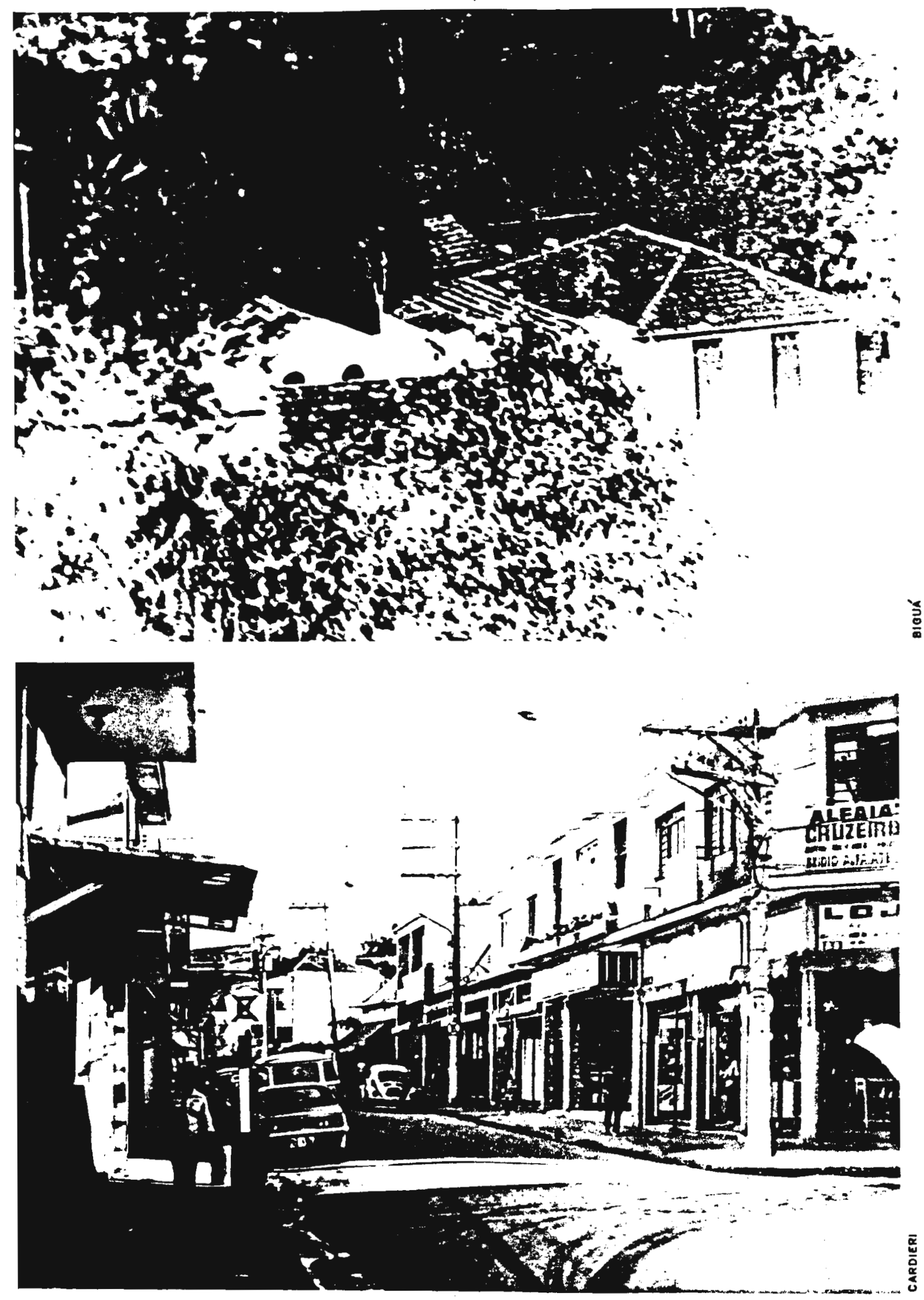

Potos 19 e 20 2 Na foto superlor, I drelta, o "armarín do Joño Balhestelro" segunda casa corercial de Jand1ra, local, hoje, ocupado pelo Bradesco. no 1Ado, O açougue do "Ouinzinho", InÍc10 da zentrallzaçáo do coméreio na Av. Conces Gão Eamnartino.

Ya foto 1 nffarlor, a Av. Conceiçāo samart 1 no em 1979 . 
Recentemente (junho de 1979), talvez por efeito da industrialização que vem ocorrendo, jā é perceptivel o apa recimento de serviços mais especializados, como por exem plo, escritōrio de engenharia, aqência de empregos,serviço medico-dentário para atender a parcela da população que aI se fixara encontrando perspectivas de trabalho no próprio municipio.

Entretanto, a especializaçäo e a melhoria quant 1 tativa nesses setores não alteraram em Jandira sua cond 1 ção de cidade modesta, e sua ligação com centros malores alnda se faz no sentido de suprir as deficiências locais.

\subsection{Equipamentos Urbanos}

A população jandirense, distribuida numa área de 22,0 Km2, carece de algumas das mals elementares comodidades geral mente encontrāveis numa comunidade urbana. A ausência de Infra-estrutura está relacionada com o modesto orçamento municipal, insuficiente para fazer frente aos gastos que seriam exigidos por obras indispensáveis, tais como insta lação de rede de água e esgoto, retiflcação e canaliza ção de corpos d'água, 1luminação pủblica, saúde pública,pa vimentação, etc. Registre-se que o próprio mecanismo arre cadador é obsoleto.

o quadro geral, portanto, apresentava-se deficien te em 1974. A começar pelo saneamento bás1co, onde o po ço ainda é o meio utilizado para se conseguir ãgua. Com exceção de três familias que obtēm āgua de "bica", a gran de maloria, 1sto é, 91,918, possuem poço, sendo que 45,578 destas familias utilizam-se de bomba elétrica para a reti rada da água; não havendo bomba, a energía humana é o melo utilizado para trazer a água até a superficle. Enquanto al gumas famillias possuem até encanamento interno, em suas ca sas, outras ainda utilizam a ägua do poço do vizinho. En tretanto, dados recentes (1979) mostram que em março de 
1978 o municiplo passou a fazer parte do "Sistema Integra do de Abastecimento de Aqua" da Região Metropolitana de são Paulo, tendo em vista a posição geogrāfica de sua área urbanizada atual, e as perspectivas do planejamento metro politano (29). Fol construldo pela SABESP um reservatório com capacidade de $5.000 \mathrm{~m} 3$ de água, que atende por enquan to a 3.000 ligações. Vide distribuição de rede na fig.XVII.

Inexiste rede de captação de esgotos. Em geral. os detritos são lançados diretamente nos cōrregos, poluin _ do-0s, contribuindo para a proliferação de doenças, compro metendo a saúde da população. Tão somente na avénida Con celção Sammartino, a via principal, existe um sistema de galeria. Constatou-se o predomín1o de fossa negra, 81,39 da amostra, servindo tanto às instalações sanitārias inter nas como às externas.

Quanto à coleta de $11 \times 0$ doméstico a s1tuação è $s \underline{1}$ milar, pois dispondo de apenas um caminhão da Prefeltura. somente a ārea central (FIg. XVIII) recebe este serviço. Na periferia o lixo é depositado a céu aberto, em terrenos vagos.

- calçamento das ruas alnda é uma asplração do po vo jandirense. Apenas a via Concelção sammartino, que faz conexão com a estrada de Itapevi e a via de acesso à Rodo via Presidente Castelo Branco, são asfaltadas. A rua Wal demar Albano e um trecho da william Wadel são pavimentadas com paralelepipedos. A Fig. XIX mostra a pavimentação pạ ra 1978. No mais, as ruas são de terra e, devido ao tipo de material argiloso al existente, tornam-se intransitáveis em dias chuvosos, principalmente nos trechos em ladeira. (foto 21 ).

(29) S.N.M. - Relatör1o Jand1ra 77 p. 32 


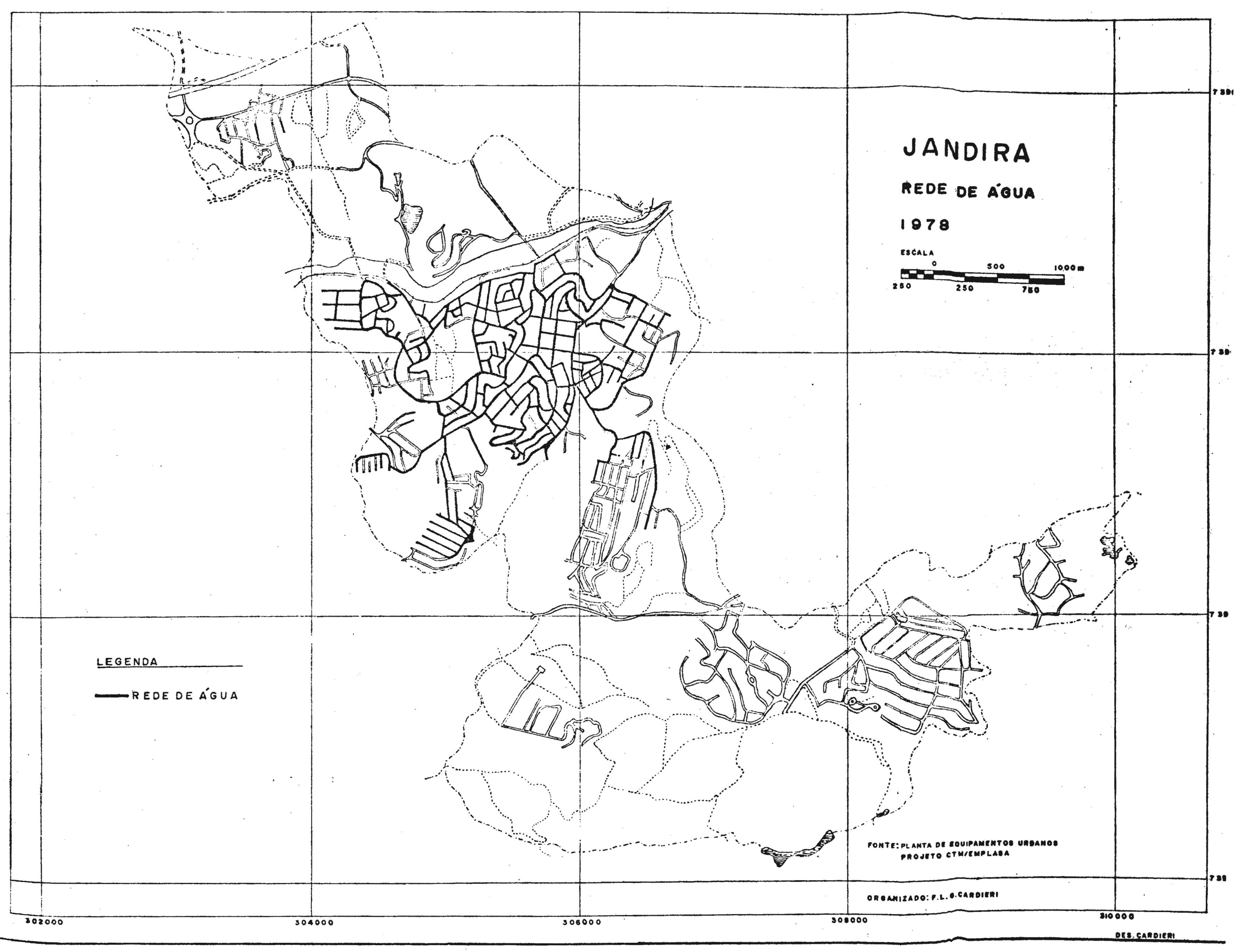




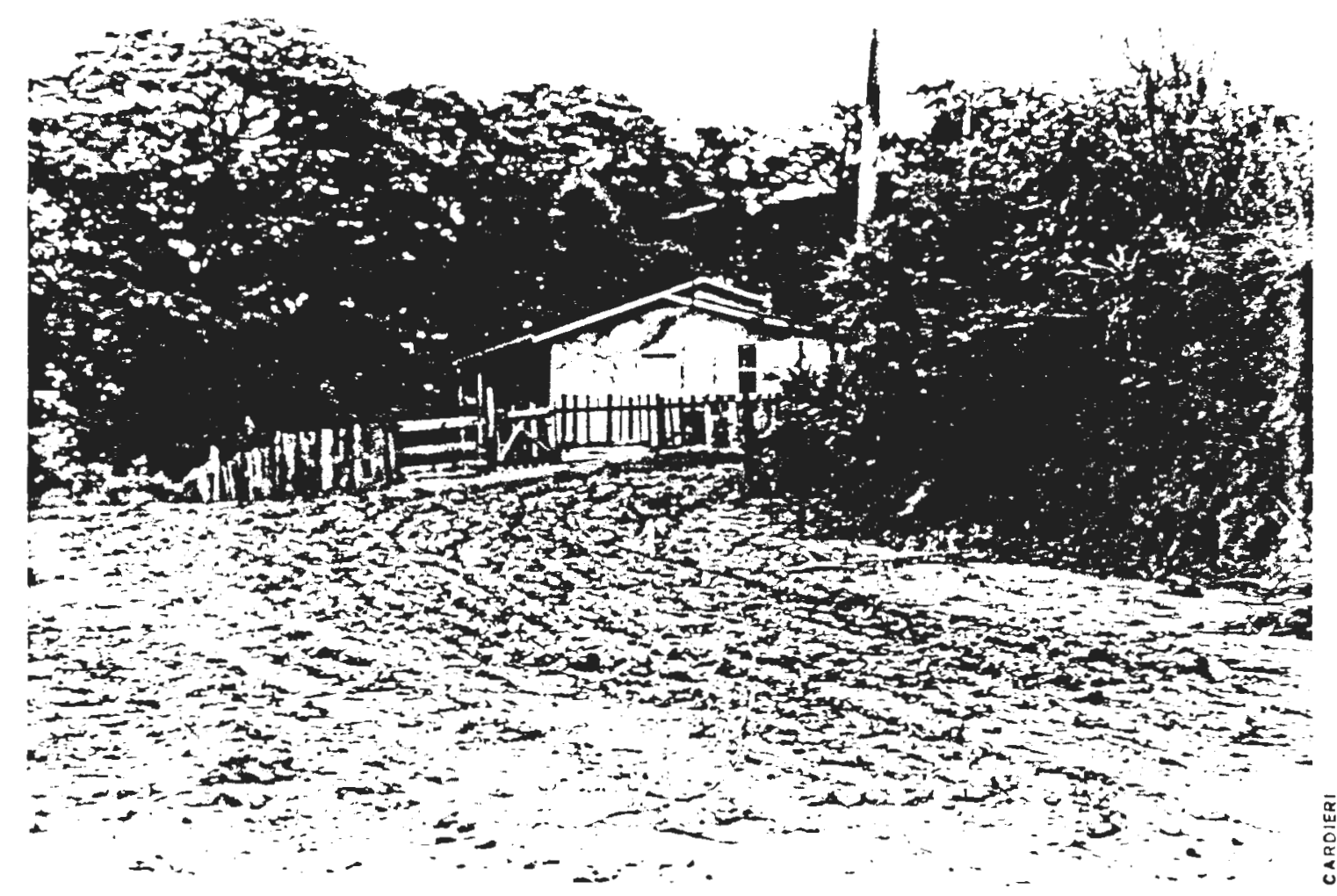

Foto 21: Pode-se observar por esta foto da Rua D.Pedro II (Vilo Ouro Verde) que as ruas fican intransi
taveis en dias de chuva.

Atè 1975 não existia rede telefônica. Como é eví dente, a lacuna dificultava as comunicações, pois havia um único aparelho (público), Instalado numa panificadora e,se gundo a população, o preço das ligações era exorbitante . A Instalação da rede da TELESP não solucionou o problema de imediato, uma vez que era diflcll conseguir falar com outras cidades (foto 22). O problema fol resolvido com a integração da cidade ao sistema DDD (discagem direta à dis tânc1a). 


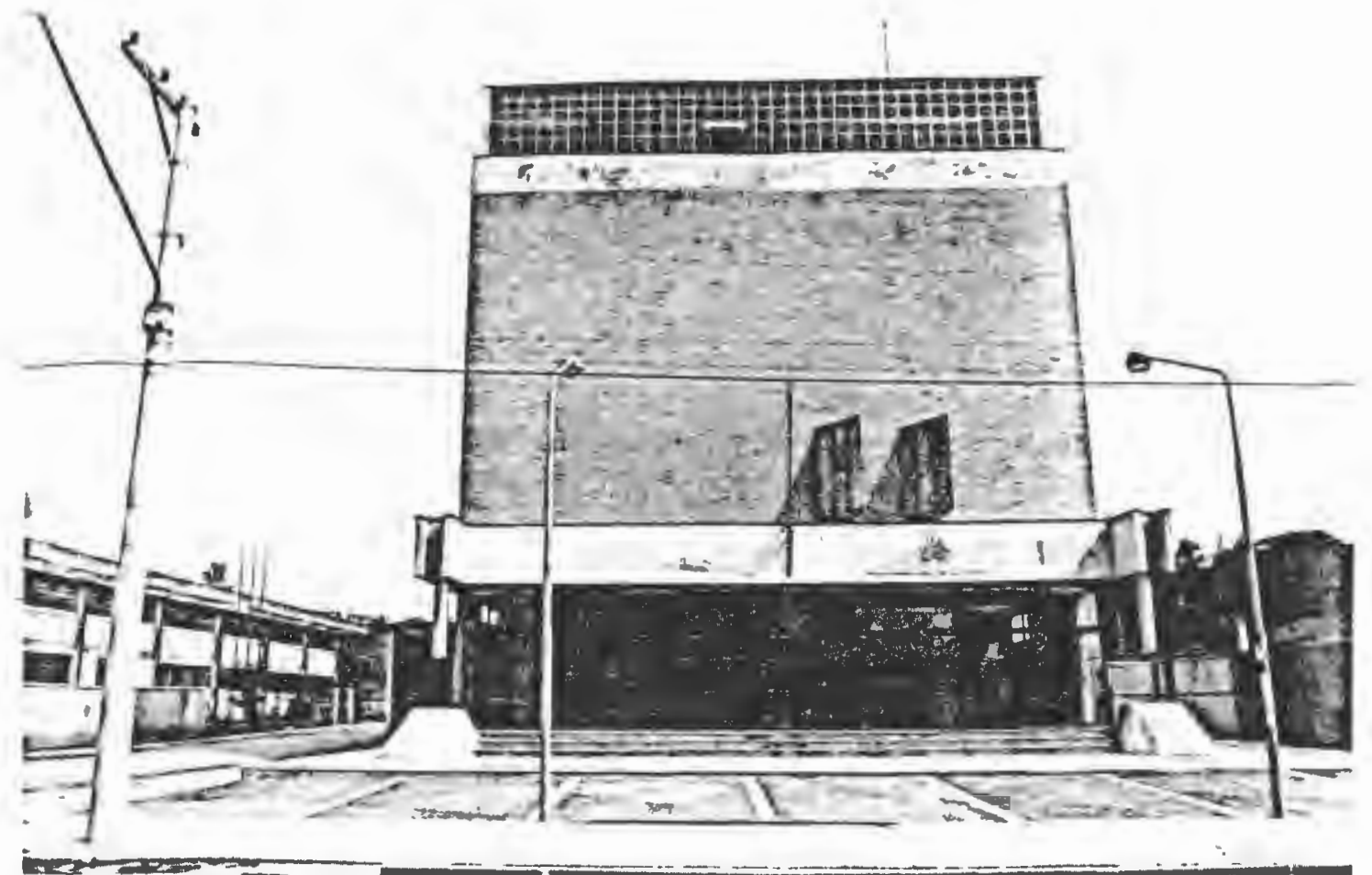

Foto 22: Prédlo da Telesp locallzado na Av. Jõ̃o Balhes

Alnda com relação a comuntcações, o serviço de Correlos (foto 23) é incompleto, pois não dispōe de te

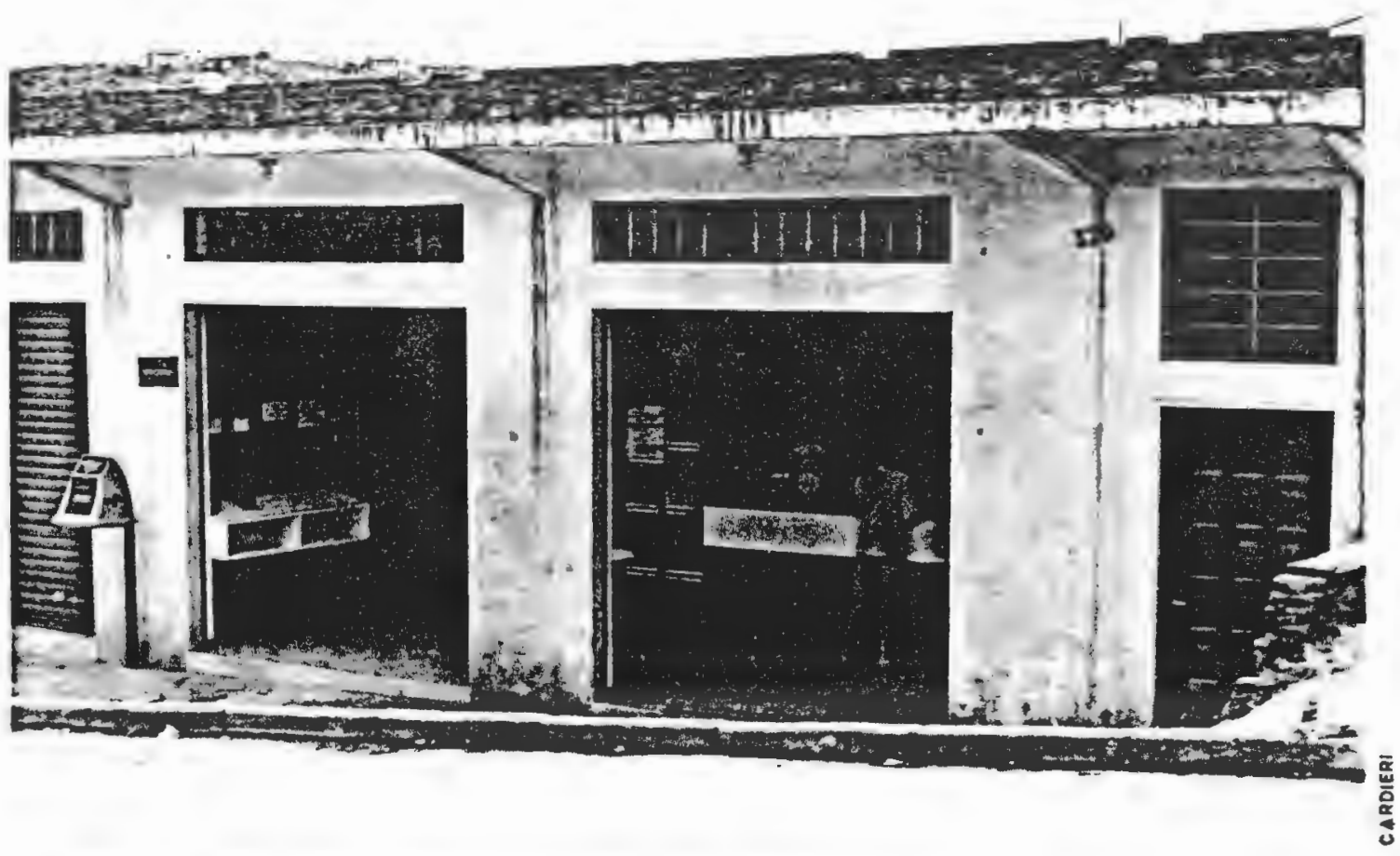

Foto 23, Novo Préd1o do Correlo local12ado na Rua H1121am Nade 11 
légrafo. Instalada em 1972, a única aqência existente fol ampliada no ano de 1979, contando atualmente com quatro carteiros e um monitor postal.

A energia elétrica domiciliar existe em quase todo - município. Nas áreas periféricas mals distantes há nẹ cessidade de outras fontes de energia, tais como querozene ou gás. Já com a 1luminação püblica o mesmo não ocorre. Somente na ārea central e ruas principais ela se faz pre sente (observe-se a distribulção na Fig. XX).

A observação criteriosa do Quadro III delxa claro que a distribuição da energia elétrica na Região Noroeste manteve um crescimento constante no período de 1972 a 1977.

QUADRO III

Light-Nümero de contas, segundo os municiplos da sub-regiāo

Noroeste - $1972-1977$

\begin{tabular}{|c|c|c|c|c|c|c|}
\hline $\begin{array}{l}\text { Ano } \\
\text { Municlpio }\end{array}$ & 1972 & 1973 & 1974 & 1975 & 1976 & 1977 \\
\hline Osasco & 46.258 & 50.201 & 53.833 & 56.317 & 60.656 & 64.970 \\
\hline Carap1cuIba & 9.387 & 11.605 & 12.938 & 14.878 & 16.882 & 20.918 \\
\hline Baruer 1 & 5.431 & 6.080 & 6.544 & 7.156 & 7.842 & 8.652 \\
\hline Itapev1 & 3.580 & 4.166 & 4.756 & 5.268 & 5.915 & 6.695 \\
\hline Jand1ra & 1.977 & 2.305 & 2.587 & 3.024 & 3.540 & 4.119 \\
\hline Cajamar & 731 & 871 & 1.081 & 1.322 & 1.691 & 2.066 \\
\hline $\begin{array}{l}\text { Santana do } \\
\text { Parnaiba }\end{array}$ & 534 & 593 & 728 & 884 & 1.060 & 1.237 \\
\hline Pirapora & 398 & 421 & 433 & 465 & 516 & 591 \\
\hline
\end{tabular}

Fonte: Boletins Estatisticos da Light

No que diz respelto ao serviço médico-odontológico, - panorama não é multo diferente. 8 recente $(1974)$ a ing talação de consultório mêdico e dentário no local. Entré 


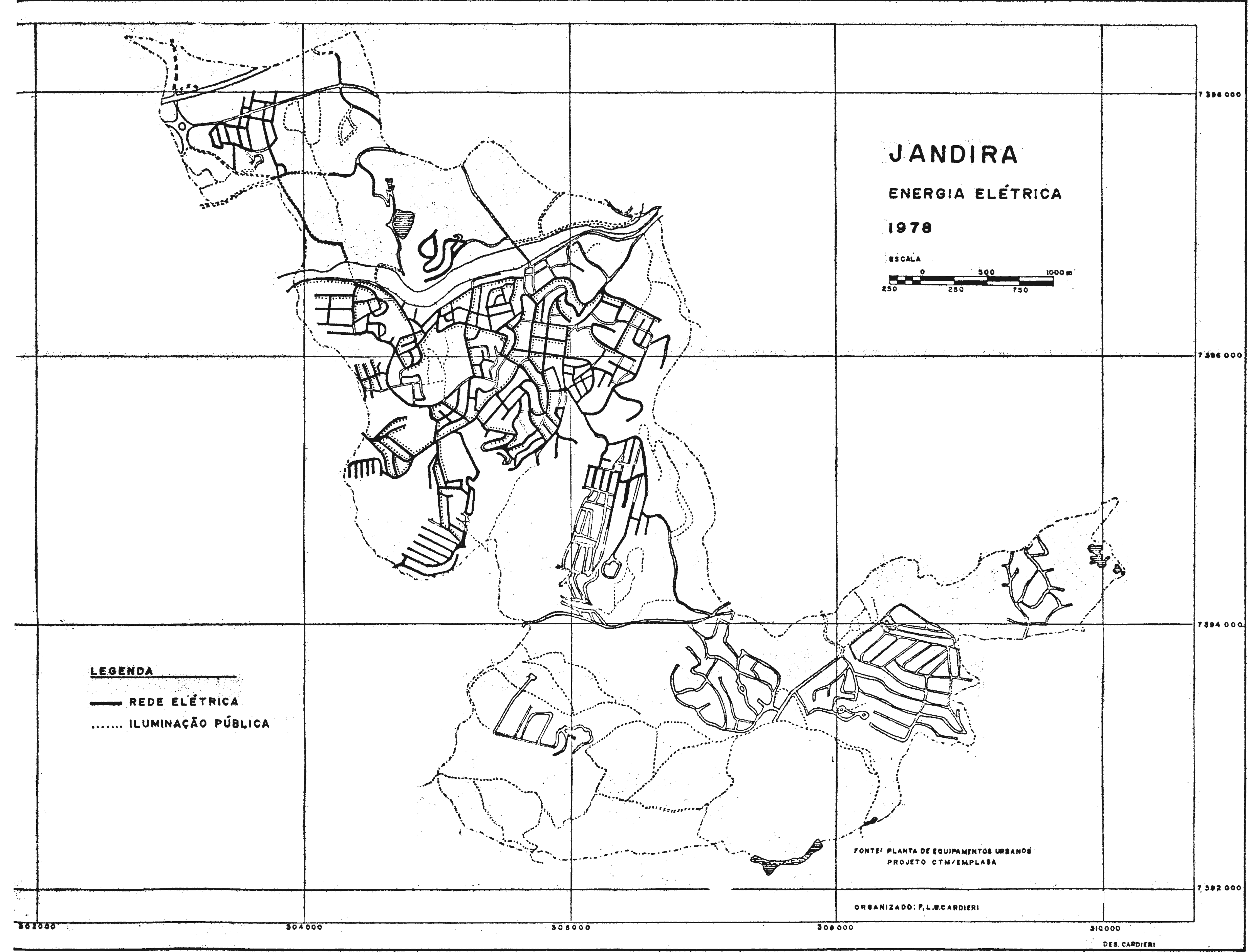


tanto, o preço elevado em relação às condições econômicas da população e o atendimento em apenas dols dias da semana, obrigam a clientela a procurar profissionais de outros cen tros. Atualmente (1979), a situação está se modificando com a fixação de médicos e dentistas na cidade.

Jandira não conta ainda com serviços hospitalares, seja de iniclativa püblica ou particular. Existe apenas um Centro de Saúde estadual, com dols médicos de fora.Pres ta os serviços rotinelros de um posto, como, por exemplo, vacinação, consulta médica, suprimentação alimentar para crianças e fornecimento de atestado de saúde (foto 24). Pa

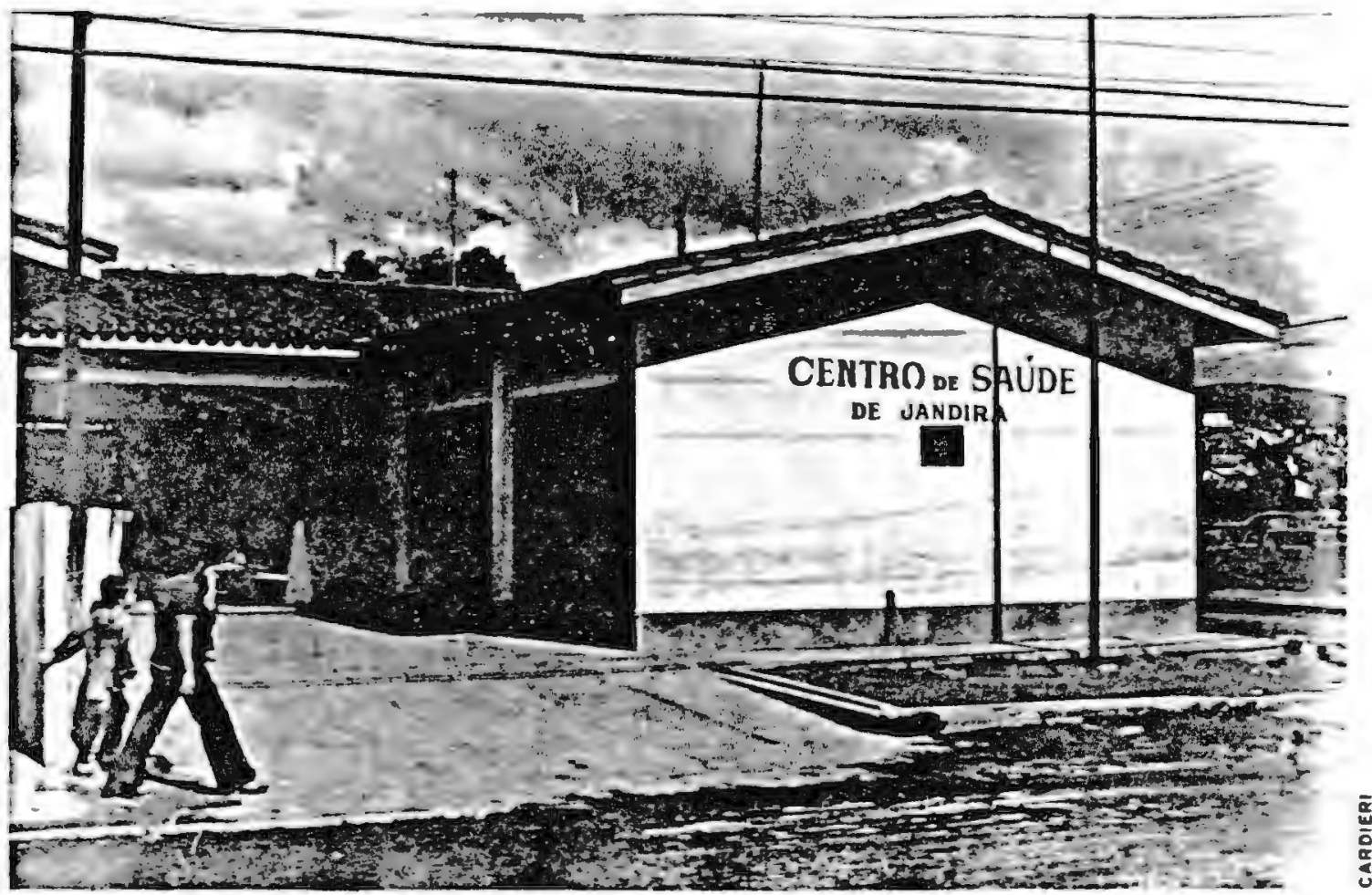

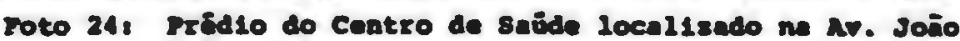
andhestelro.

ralelo ao Centro de Saúde funciona o CIAM (Centro de Inte gração de Atividades Médicas) em convênio com o M.T.P.S. (Ministério do Trabalho e Previdência Social), no horärio 
das 17 às 21 horas, com atendimento restrito aos adultos é exclusivamente para consulta médica. Os casos graves são encaminhados para outros municipios, principalmente osasco e são Paulo. A Prefeitura dispõe de duas ambulâncias para as emergências.

Além disto, as indústrias locals estabeleceram convê. nio com um pronto socorro particular para o atendimento de seus funcionários.

o serviço educacional é oferecido pelo Estado, com auxilio da municipalidade, para a sua manutenção.

Para o ensino prē-escolar a cidade dispōe de un es tabelecimento de sua competência.

Possui sete escolas (duas das quais relativamente grandes) que atendem ao ensino de 19 grau. Uma delas pos sui o ensino de 29 grau, com funcionamento noturno ( fotos 25 e 26).

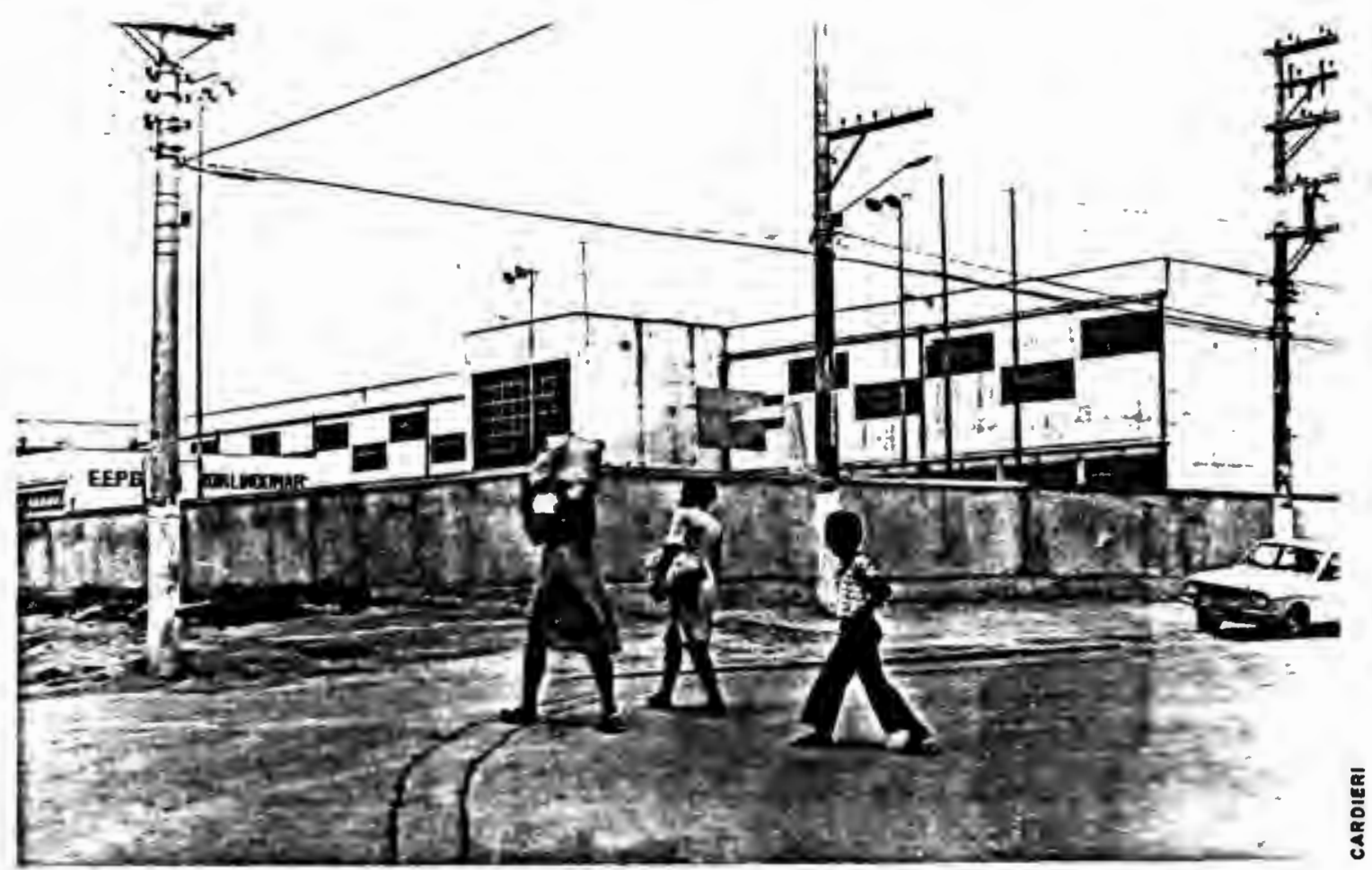

Poto 25: Escole Eatadual de Primalro Grau Oswaldo Samirti

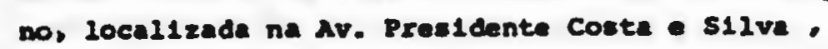
Jardim Indosar. 


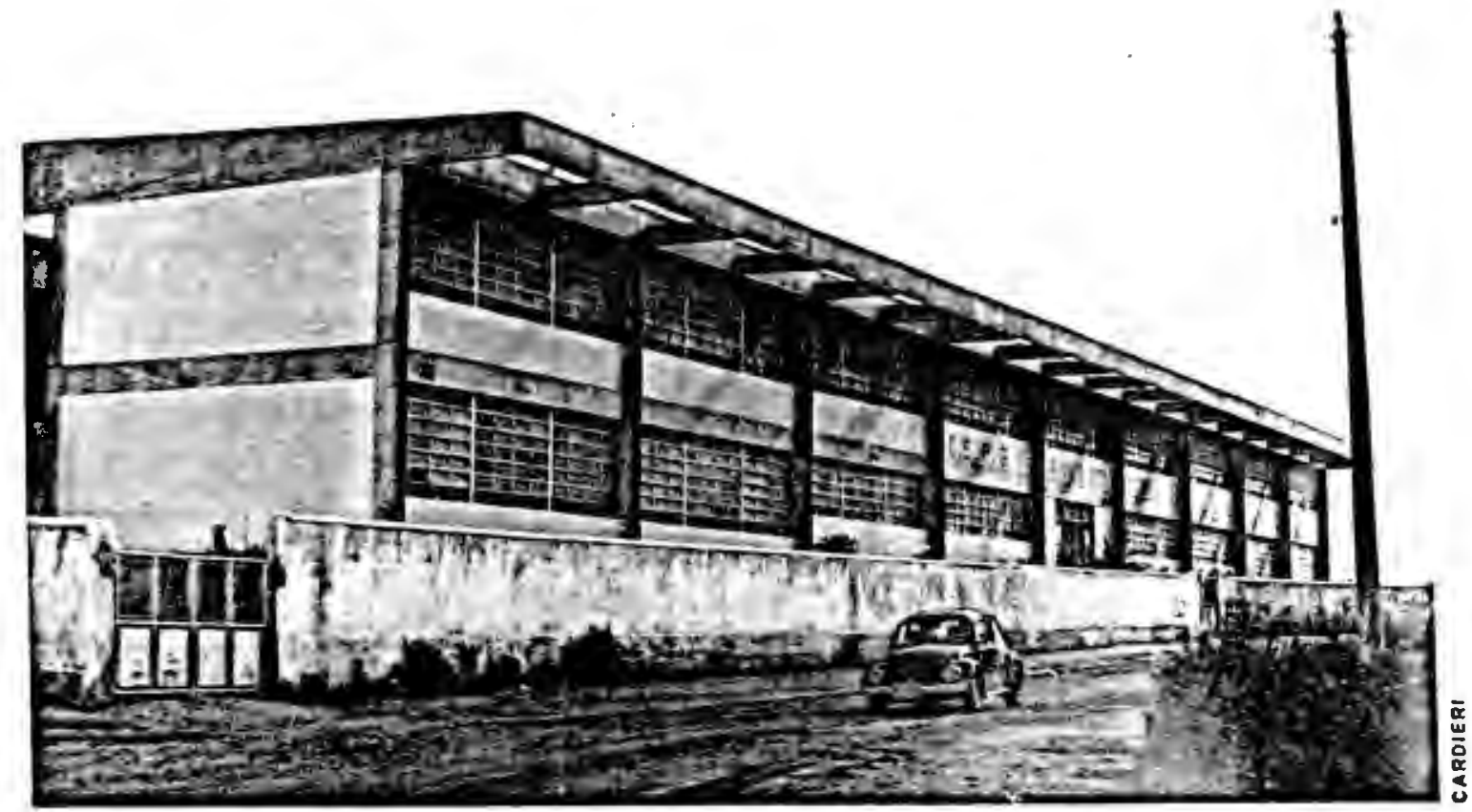

Foto 268 Escola Estadul de Primelro Grau de vila Santo Antonlo, locallzada na Rua Javaés, vila santo An ton10.

Como seria de se esperar, o corpo docente const tu1-se principalmente de professores que não residem em Jand1ra.

No Quadro IV (Matriculas no Curso de 18 grau), ev1 dencla-se uma evasão praticamente constante e crescente da 1a à 8a sérıe, uma vez que o número de matrículas diminuı a cada série (vide Quadro v Curso completo das Pessoas).

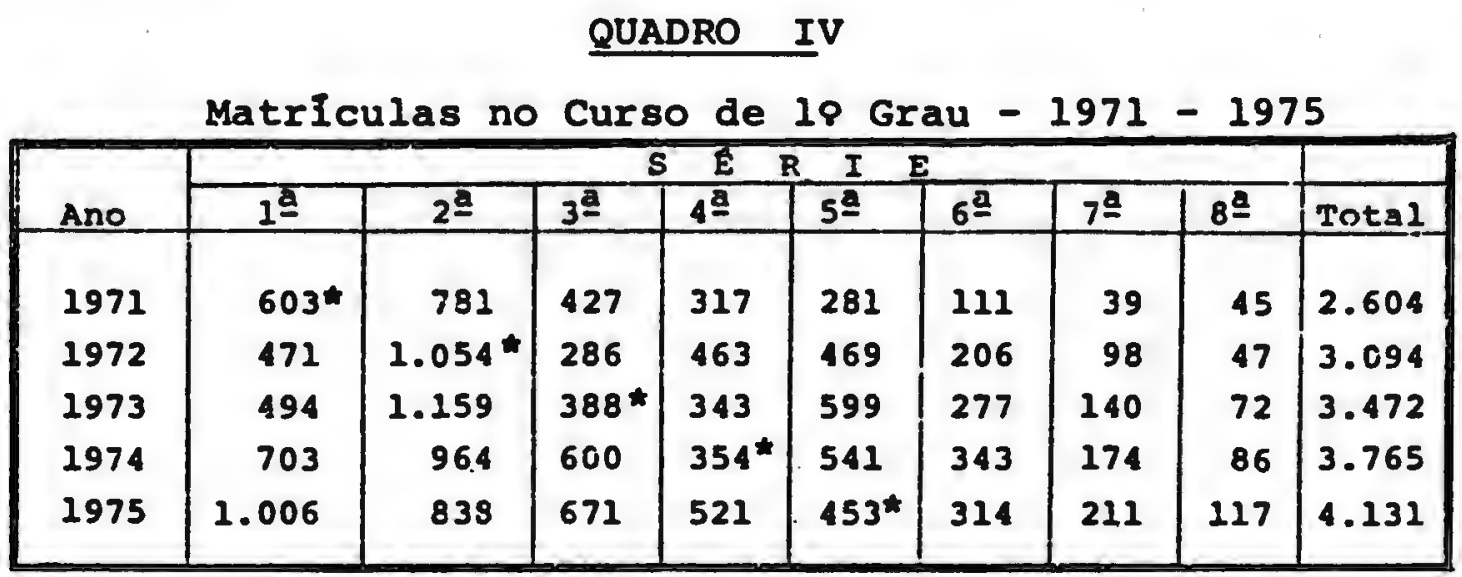

(*) Evasão constatada.

Fonte: Secretaria da Educação - Centro de Informaçōes Educacionais. 
Curso completo das pessoas de dez anos e mais, por sexo-1970

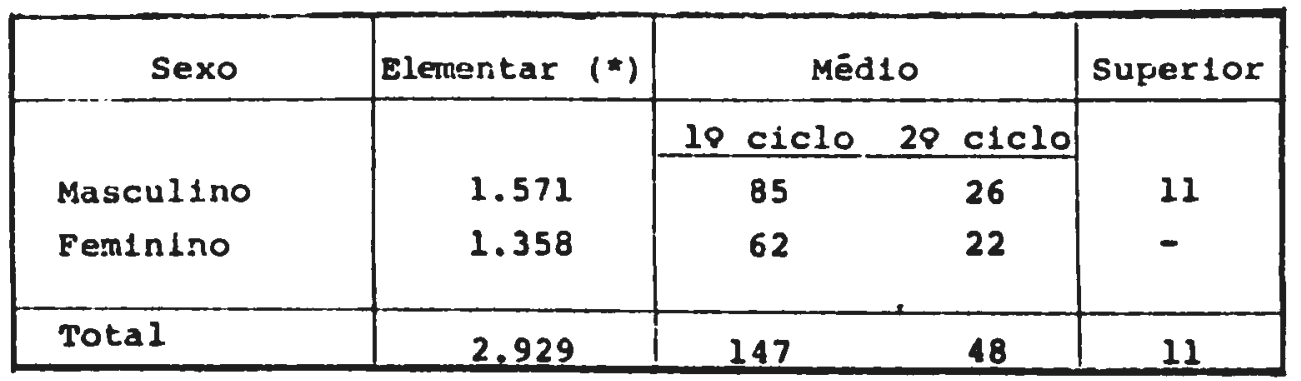

(*) Elementar corresponde ao antigo curso primārio ( $1^{\text {a }}$ à $4^{\text {a }}$ série do atual 18 grau)

Fonte: FIBGE, Censo Demogrāfico, 1970.

Não existem escolas particulares de ensino regula mentar. Quanto ao ensino profissionalizante, existe uma escola de datilografia funcionando emonze períodos de uma hora.Suas quinze máquinas em funcionamento possibilitam a frequência diária de cento e vinte e cinco alunos. No ensi no de 28 grau, são profissionalizantes os cursos de técn 1 co em contabilidade e magistērio.

o comércio é muito reduzido. Mesmo dispondo de no venta e nove estabelecimentos, 1sto em 1974, estes são, em sua malorla, constituídos por pequenos bares ou armazéns de secos e molhados, com caracteristicas das "vendas" antigas e com grande varledade de mercadorias(30). o pequeno comer cio se concentra ao redor da praça Antelo Gragnano(foto 27) e ao longo da avenida Concelção Sammartino(31). Duas falras

(30) Secretarla da Fazenda (CINEF)

(31) Juergen Richard LANGENBUCH, in A estruturação da Gran de São Paulo, 1971-p. 262 classifica Jandira como "sŭ búrbio-estação". o autor na p. 151 tratando do assuñ to diz: "nos subūrbịos-estação" (sucessores em geraI dos "povoados-estação") tende a se esboçar um zonea mento funcional muito simples: junto à estação conceñ tram-se o comércio e a prestação de serviços, na maior parte dos casos apresentando um desenvolvimento modes to e limitado. Em torno estende-se a ärea residencial". 


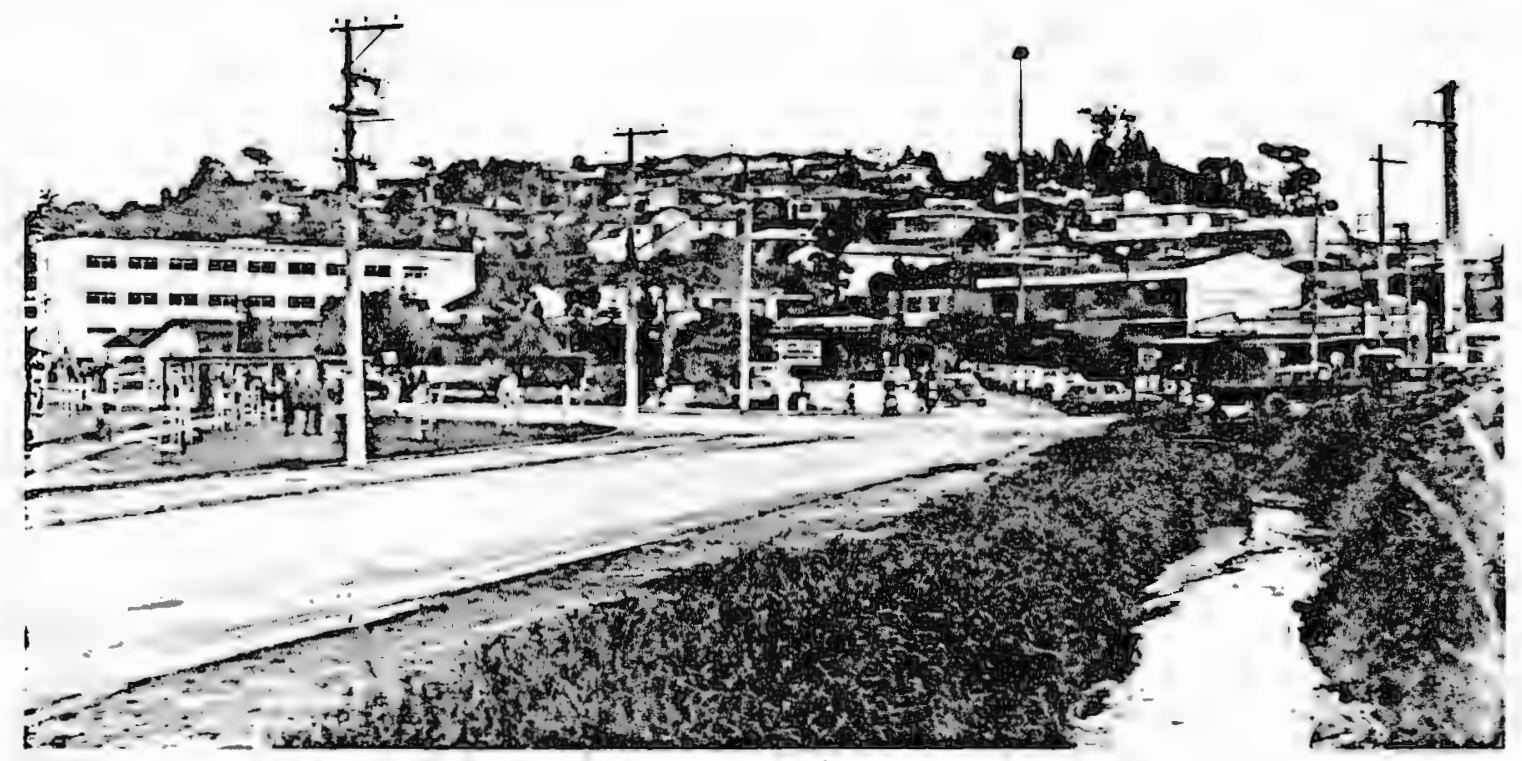

Foto 27, Praga An1elo Gragnano en 1979.

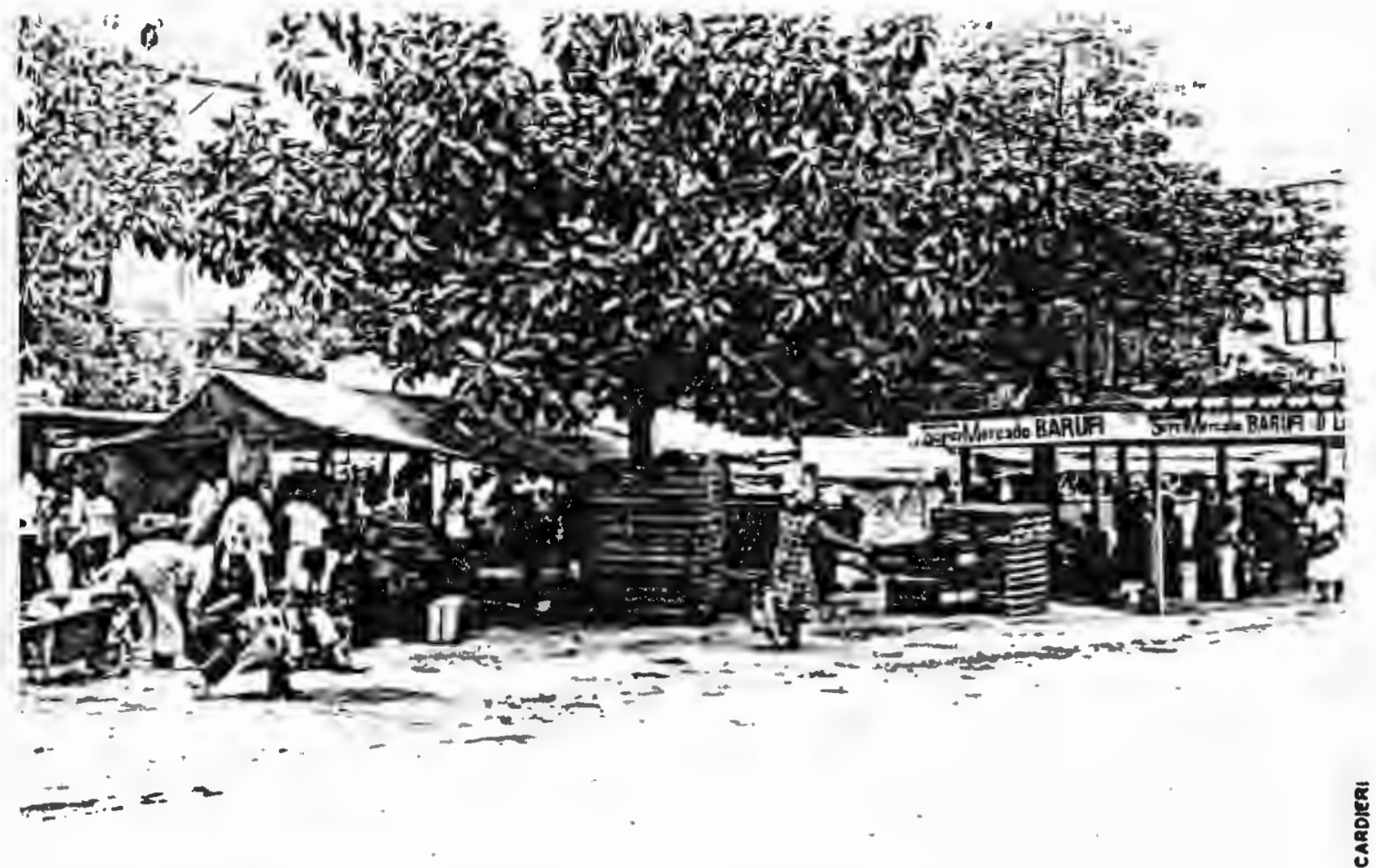

Poto 26, Aspecto da felra-11vxe real1zada no "Largo 8 de Dezembro". 
livres (foto 28) que se realizam às terças felras e aos sạ bados (32), completam o quadro comercial de Jandira. Atual mente (1979), o municlpio possui perto de quatrocentos e cinquenta estabelecimentos comercials, o que retrata expan são considerável.

A recente implantação de indústrias vem se refletin do no comércio que, deficiente até então, vê-se levado a se expandir, pela demanda da população.

Apesar de a ferrovia ser normalmente um estimulo pa ra a fixação de indūstrias, 1sto não aconteceu no caso de Jandira. Apenas o frigorifico, localizado a pouca distân cla dos trilhos, apontou como causa de instalação, entre outras, a facilidade oferecida pela ferrovia. Contudo , esta localização pode estar associada também ao carater "repugnante" de sua categorla industrial, como bem lembrou Langenbuch (1971) em sua análise das categorias de indúg trias nos subúrbios paulistanos.

(32) Alberto Ruffola, flscal das Feiras Livres do municipio, entrevistado, informou que elas tiveram um cres cimento superior ao esperado.

Realizam-se às 3 as. feiras e aos säbados no Largo 8 de Dezembro, segulndo pela antiga rua Sabiá,atual rua Brigadeiro Faria Lima. Todavia, exatamente porque cresceram multo, não há mals condiçōes de sua permanêncla no local indicado, pois o espaço não comportaas barracas existentes. Assim, já se conseguiu com a Prefeitura uma área maior, cujo planejamento está pronto, dependendo apenas de entendimentos com os fel rantes para se processar a mudança. A área a ser ocu pada tem $700 \mathrm{~m} 2$, ocupando três quadras e possibilitañ do melhor distribuição espacial dos produtos a serem vendidos: uma quadra para verduras e legumes, outra para roupas, e uma terceira para ovos, cereais e car nes, ficando os peixes numa área ocupada por um bue $\bar{I}$ ro, que é o prolongamento de uma dessas quadras. cō mo a proporção maior de felrantes é de fora, o munici plo está oferecendo incentivos aos seus habitantes, pa ra que também exerçam aquela atividade.

Assim, qualquer jandirense tem abatimento de 508 na respectiva licença. 
A Delegacia de Policia (foto 29) presta os servi-

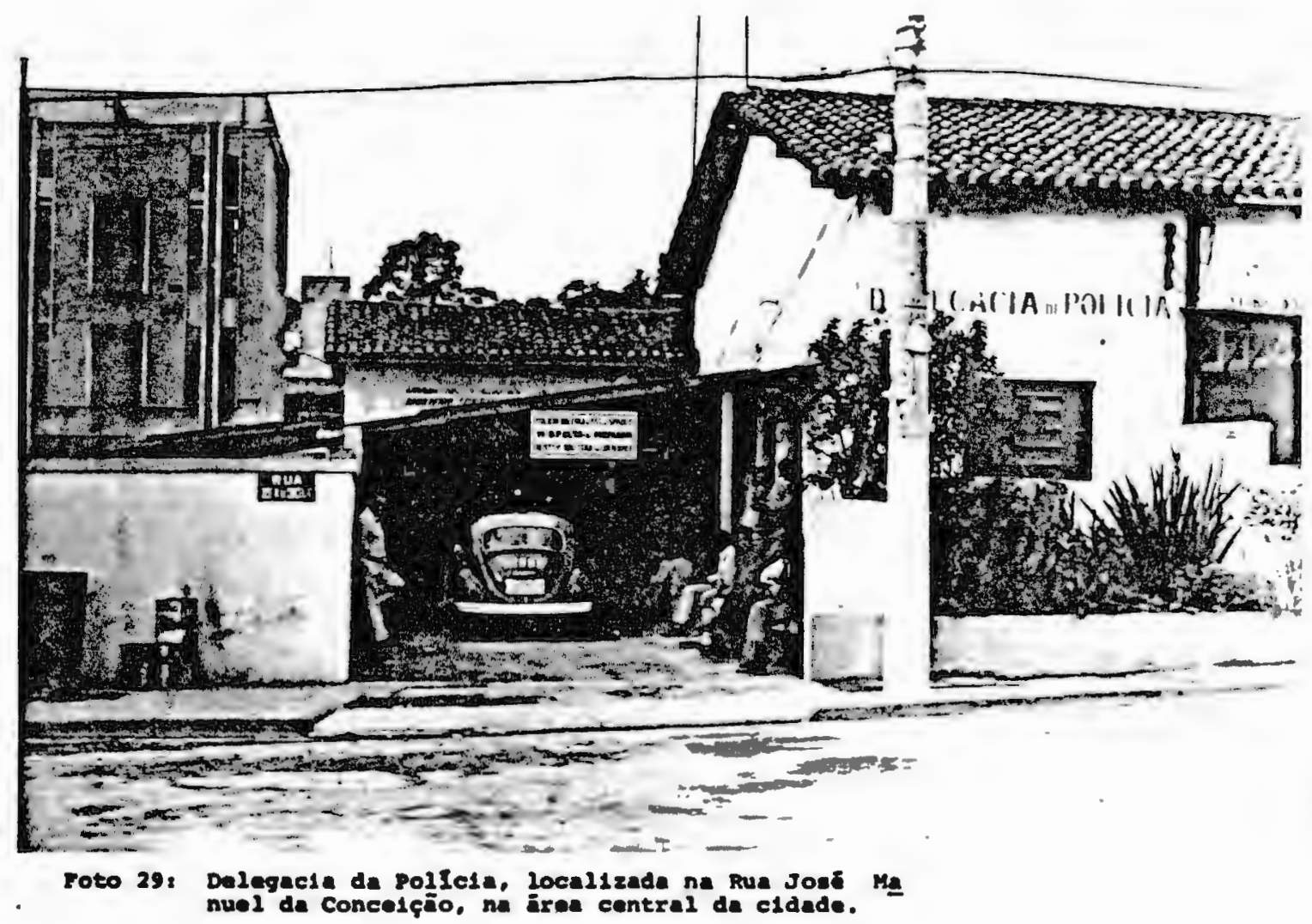

ços de fornecimento de atestado de pobreza, de residência e dependência econômica. No que se refere a atestado de antecedentes, tanto politico-social como criminal, só dispõe de condições para antecedentes locais, por isso é procurada, em tais casos apenas quando a empresa aceita este tipo de atestado, geralmente solicitado para admissãode funcionärio.

Para obtenção do Registro Geral-Carteira de Identida de e atestado de antecedentes politico-socials e criminais, os moradores têm de se dirigir a outros centros.

o serviço de Administração Financelra, que retrata a economia local, é representado por uma agência da Coletorta 
Estadual (foto 30 ) que recebe os tributos de ICM e outros serviços correlatos.

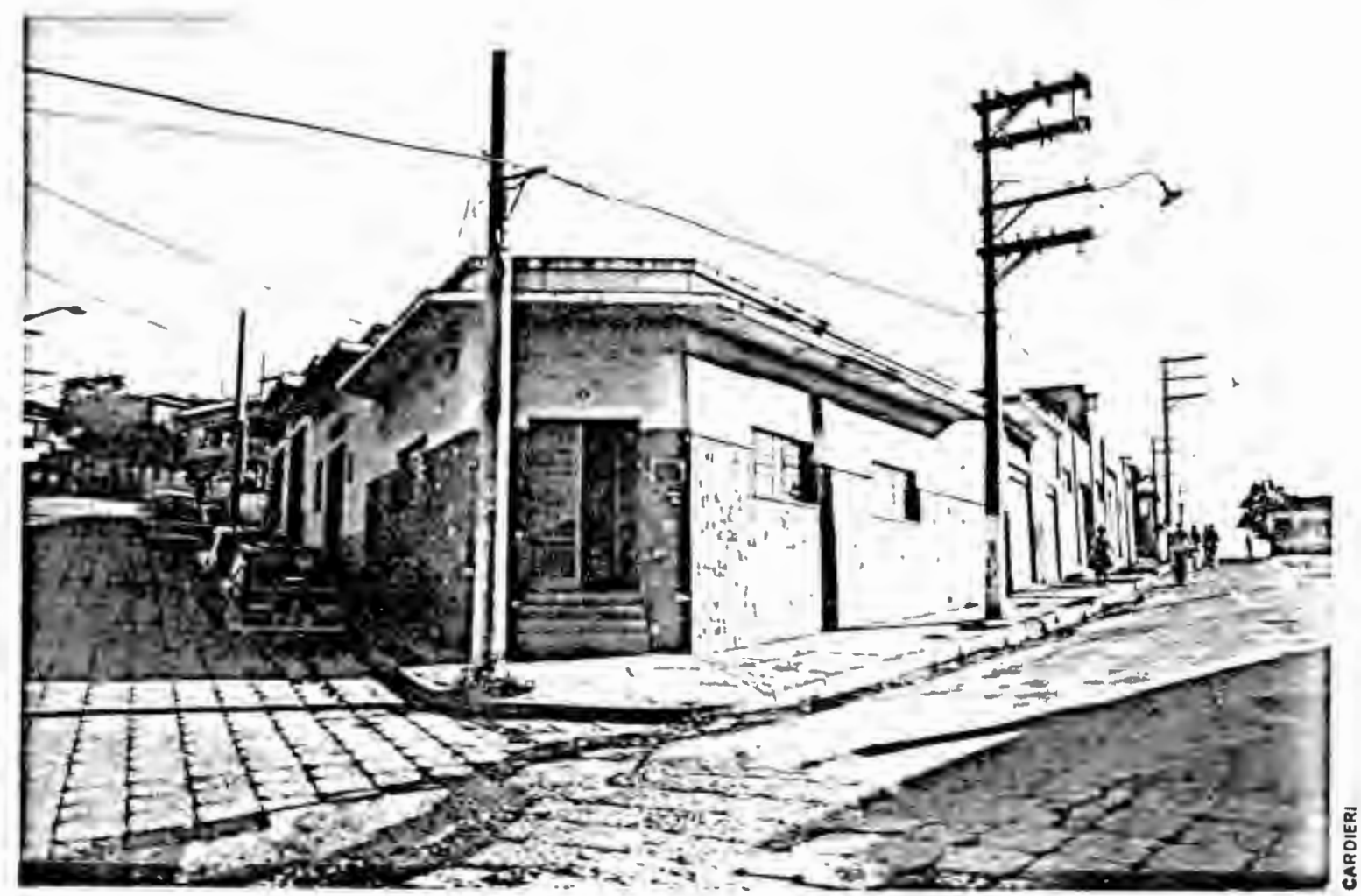

Poto $30 \mathrm{z}$ Em prime1ro plano a Coletor1a Faderal, local1zada na Rua will1an Wadel1. A esquerda os eacr1 to rlos da light a Sabesp (Rua Waldenar Albano).

o único estabelecimento bancário é a agência do Ban co Brasileiro de Descontos (foto 31). Nele trabalham qua renta e cinco pessoas (1979), 708 das quais jandirenses e presta todos os serviços inerentes a um banco. Possui nove mil contas correntes, das quais oito mil em média, em movi mento. 0 impulso considerāvel recebido nos ültimos anos. jā que possula apenas nove funcionários em 1974, levou o estabelecimento a adquirir sede própria e propiciar melhor atendimento aos seus clientes. 


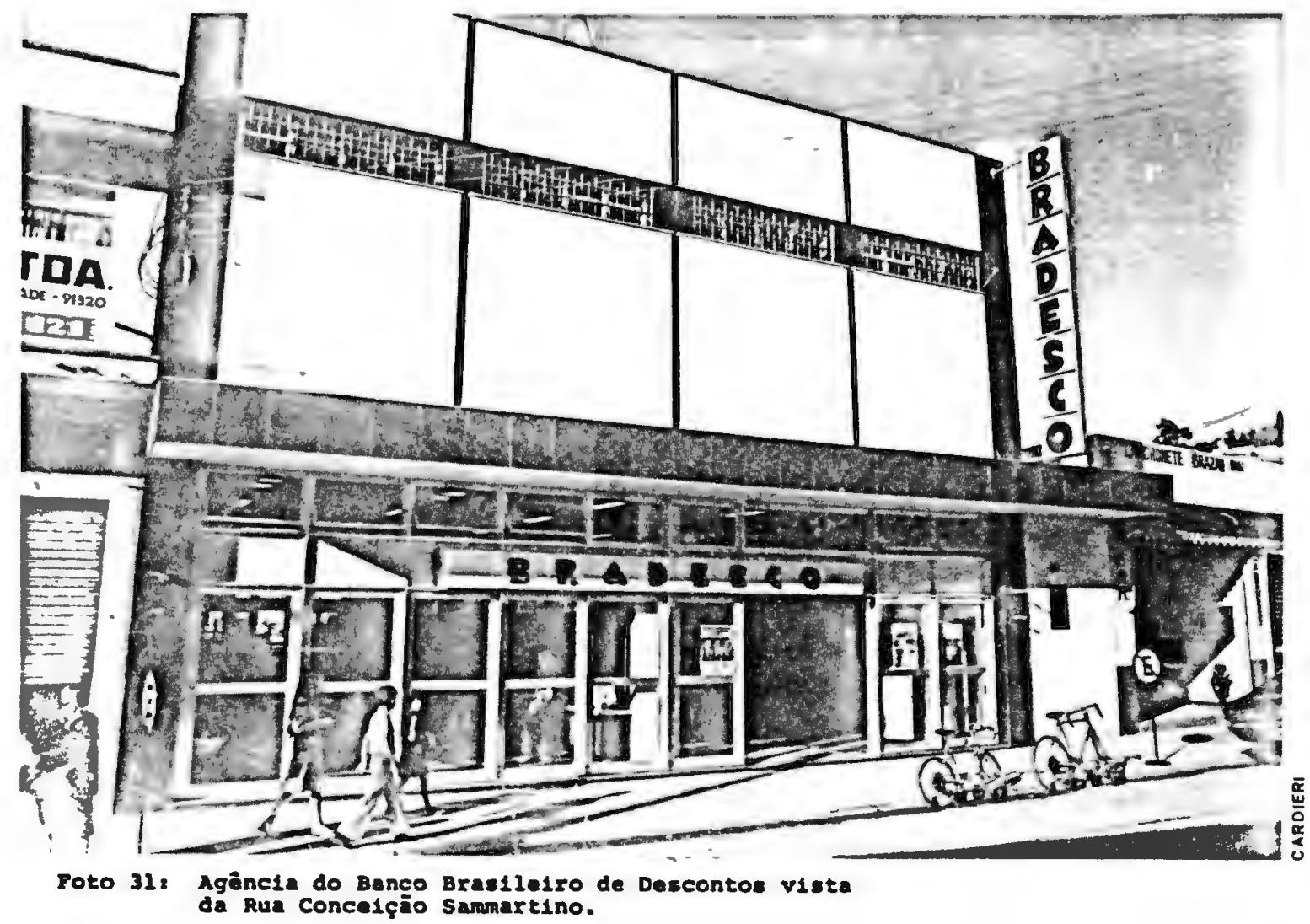

Os serviços de contabilidade fiscal, despachos po licials e advocacia são pouco especializados, refletindo , mais uma vez, a inexpressividade do comércio e da indústria locals, apesar da expansão que vem ocorrendo.

Três escritórios de advocacia,três de contabilidade fiscal, dois para despachos policials, um escritōrio de en genharia e cinco imobiliárias formam o quadro de prestação desses serviços no município.

As serventias do Poder Judiciärio são representadas por um cartório de registro civil e tabelionato.

As 1mobiliárias desempenham papel de destaque no co mércio de terrenos, com o impulso dado à cidade pela 1mplan taçāo de indústrias. 
No que se refere a Transporte e Sistema Viário, o mu nicípio é cruzado no sentido Leste-Oeste pelos trilhos da FEPASA, (foto 32) que saem de são Paulo, passam pelos munt

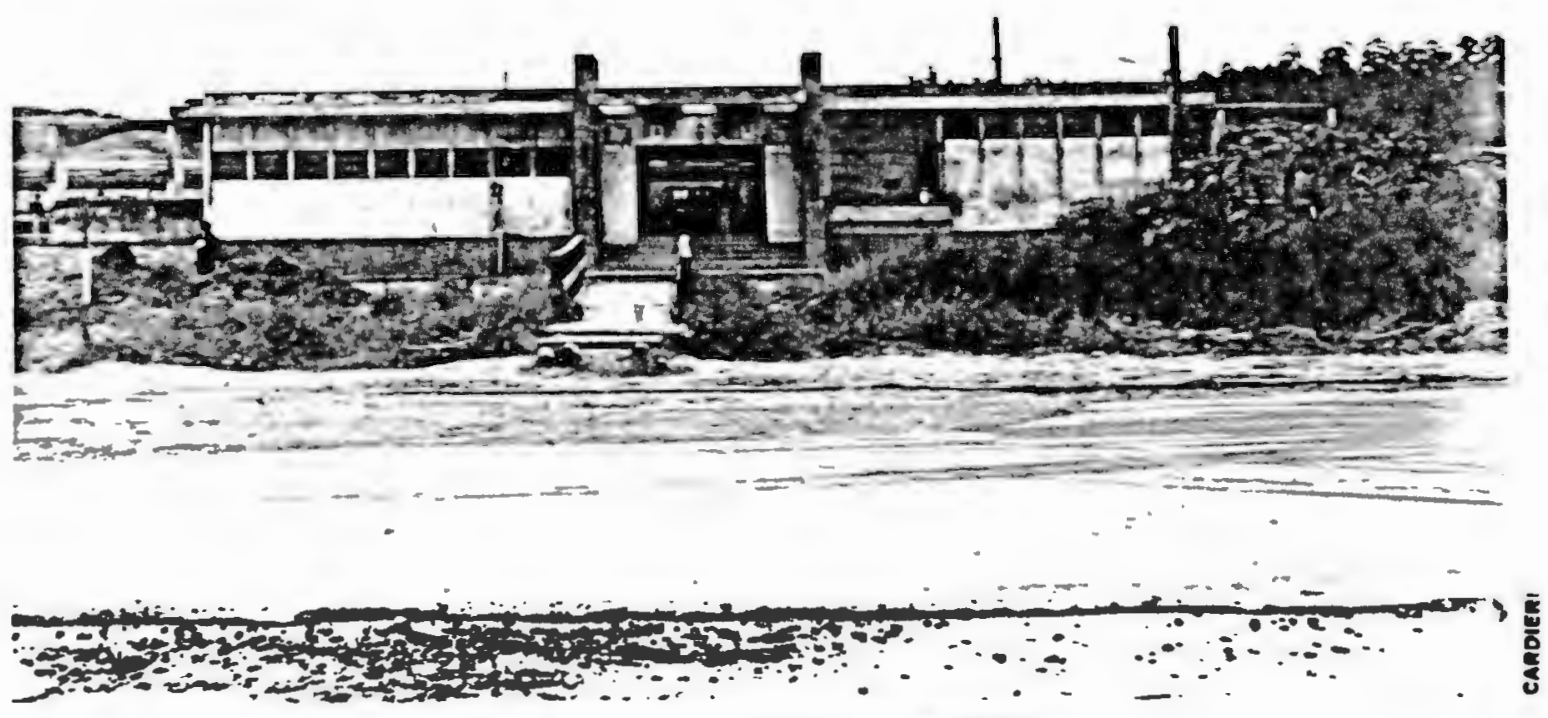

Foto 32: Estapio ferroviäria atual, 1navgureda em outubro de 1962.

cÍpios de Osasco, Carapicuíba, Barueri e Itapevi na Grande são Paulo e continuam em direção ao oeste do Estado, atin gindo a cidade de Presidente Epitácio, às margens do Rio Pa raná, limite dos Estados de São Paulo e Mato Grosso do Sul. Ao norte, é cortado pela Rodovia Castelo Branco (SP 280) , também construía em direção ao oeste do Estado, concluía até Avaré (Interior do Estado) ligando-se com a Via Raposo Tavares (SP 270).

Ao Sul, a estrada de Itapevi (SP 274), cujo traçado Inicla-se em Barueri, passa por Jandira e segue em direçāoa Itapevi, cortando o municipio de Cotia, onde se liga à Via Raposo Tavares. 
Há ainda dois acessos rodoviários; um,pavimentado , ao sul da ferrovia, e outro,ao norte da mesma, ligando Jan dira a Itapevi ( vide Fia. XXI).

o município está inteqrado à região, jā que é servi do por ferrovia e rodovia intermunicipais. Internamente, as ligações entre bairros e destes com o centro são feitas a través de ruas e avenidas, traduzindo o sistema viário lo cal.

o transporte coletivo de passageiros é felto por ônibus, com frequēncia de trinta em trinta minutos, e trens de subúrbio, de cinquenta em cinquenta minutos, para a cap 1 tal.

Ainda por ônibus, Ilga-se o municíplo a são Paulo. Osasco, Carapicuíba, Barueri, Itapevi e Cotia,com as seguin tes linhas:

QUADRO VI

DEMONSTRATIVO DO ATENDIMENTO INTERMUNICIPAL

\begin{tabular}{|llll|}
\hline \multicolumn{1}{|c}{ Empresa } & \multicolumn{1}{c}{ Nome da Linha } & Faixa Horāria Dia/ \\
\hline & & & \\
Sta. Clara & Jandira-Barueri-S. Paulo & $04: 00-01: 10$ & 39 \\
Sta. Clara & Jandira-S. Paulo (Lapa) & $04: 00-23: 00$ & 37 \\
Sta. Clara & Jandira-Osasco & $05: 00-21: 00$ & 31 \\
Sta. Clara & Cotia - Jandira & $06: 30-18: 30$ & 7 \\
Himalaia (*) Cotia S. Paulo (V.Jandira) & $05: 00-17: 00$ & 3 \\
$(*)$ linha rodoviária & & \\
\hline
\end{tabular}

Fonte: Relatório Jandira S.N.M. - 1977 


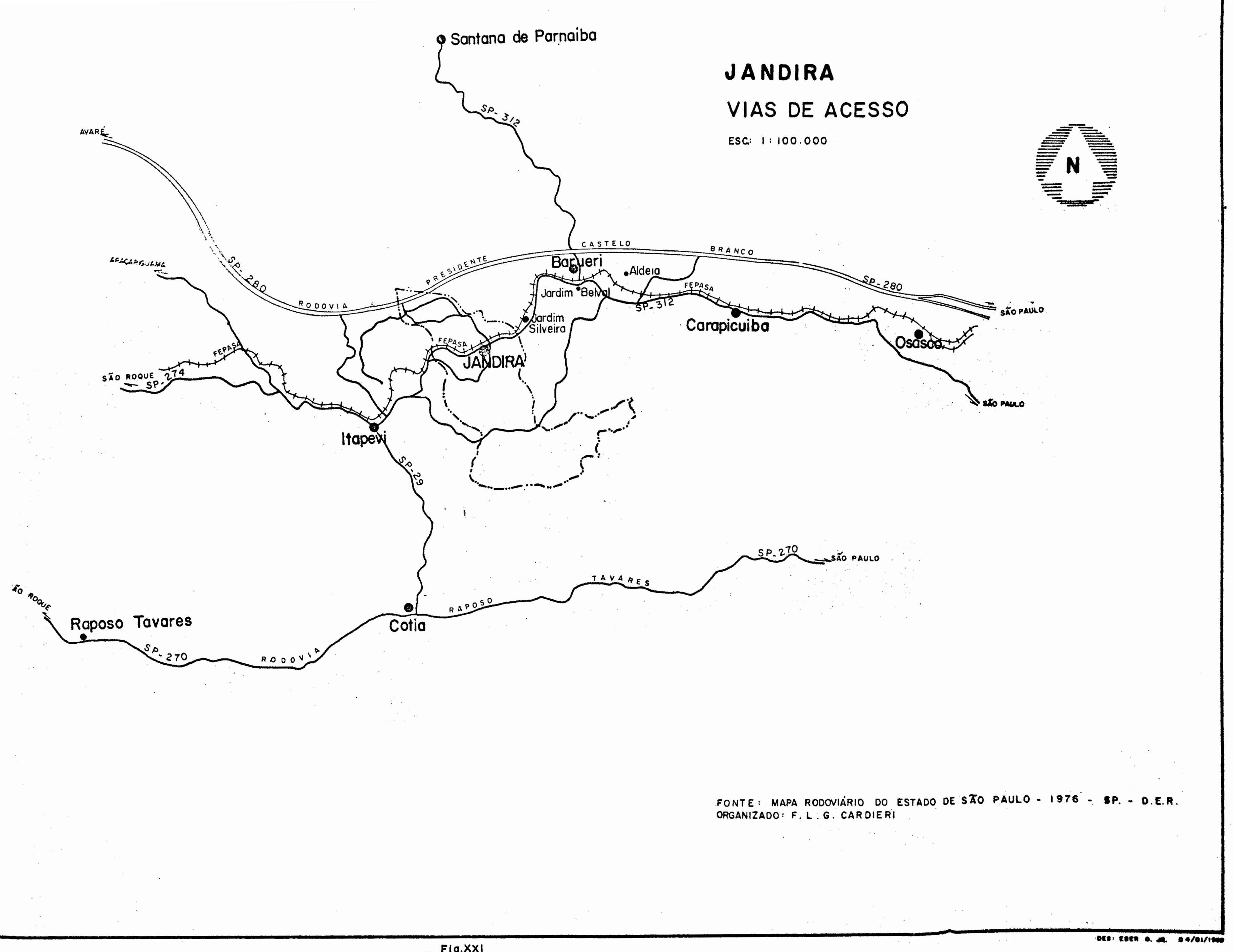


O trajeto percorrido pelo trem è tido como satisfa tório, só deixando a desejar o nūmero de viagens e no nível de conforto oferecido aos passageiros.

o transporte urbano é feito por uma empresa part 1 cular, "Transportadora Turistica Benfica Ltda.",que movimen ta três linhas, servindo aos bairros são Nicolau,Jardim Ga briela e Jardim Alvorada, sendo que os dols primeiros con tam com do1s velculos e o outro, com apenas um. Todos eles tèm seu ponto Inicial na Praça Anielo Gragnano (foto 33 e 34). 

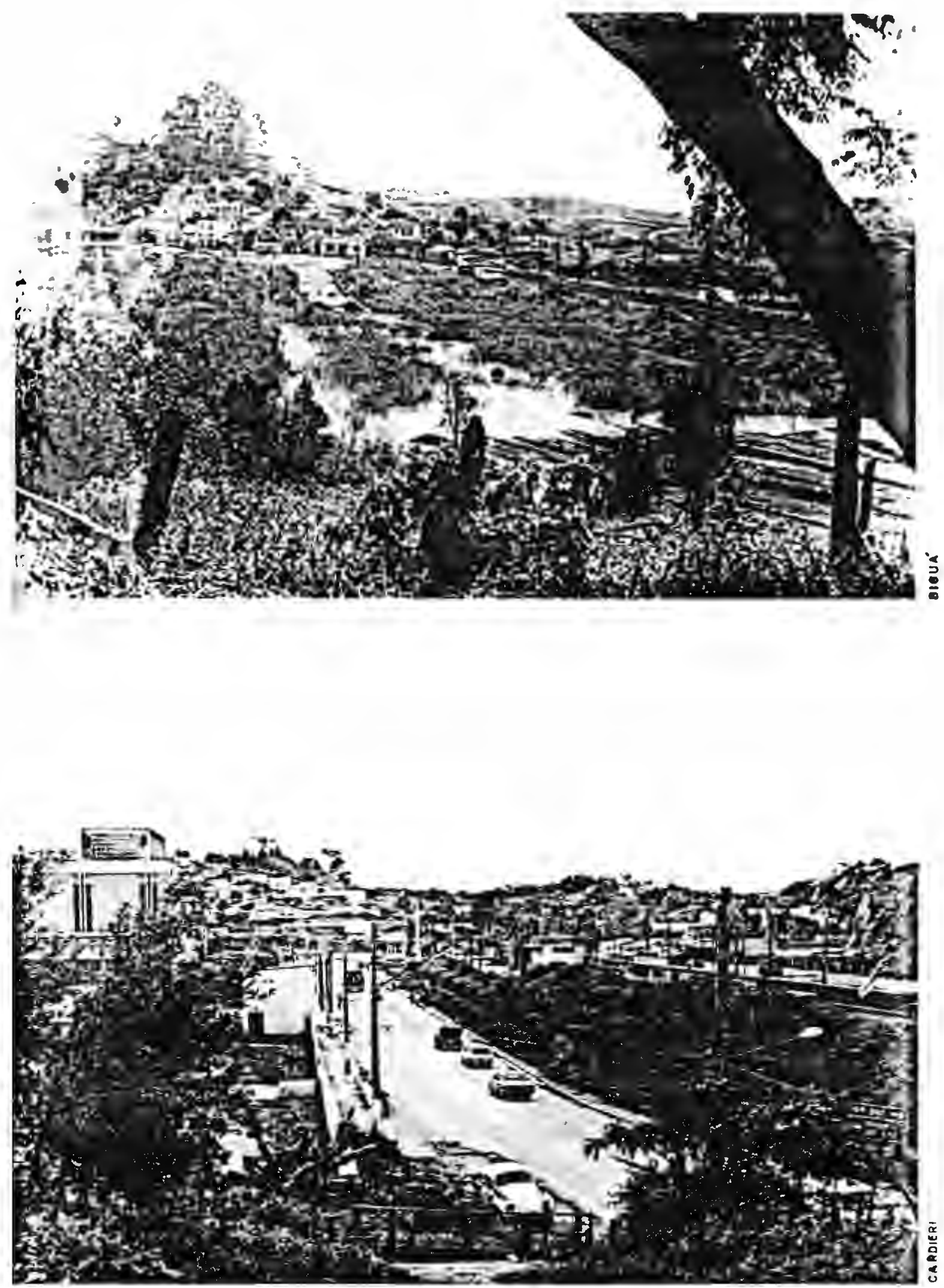

Fotos 33 - 343 Arzedores da Estuçāo en 1959 - 1979. 


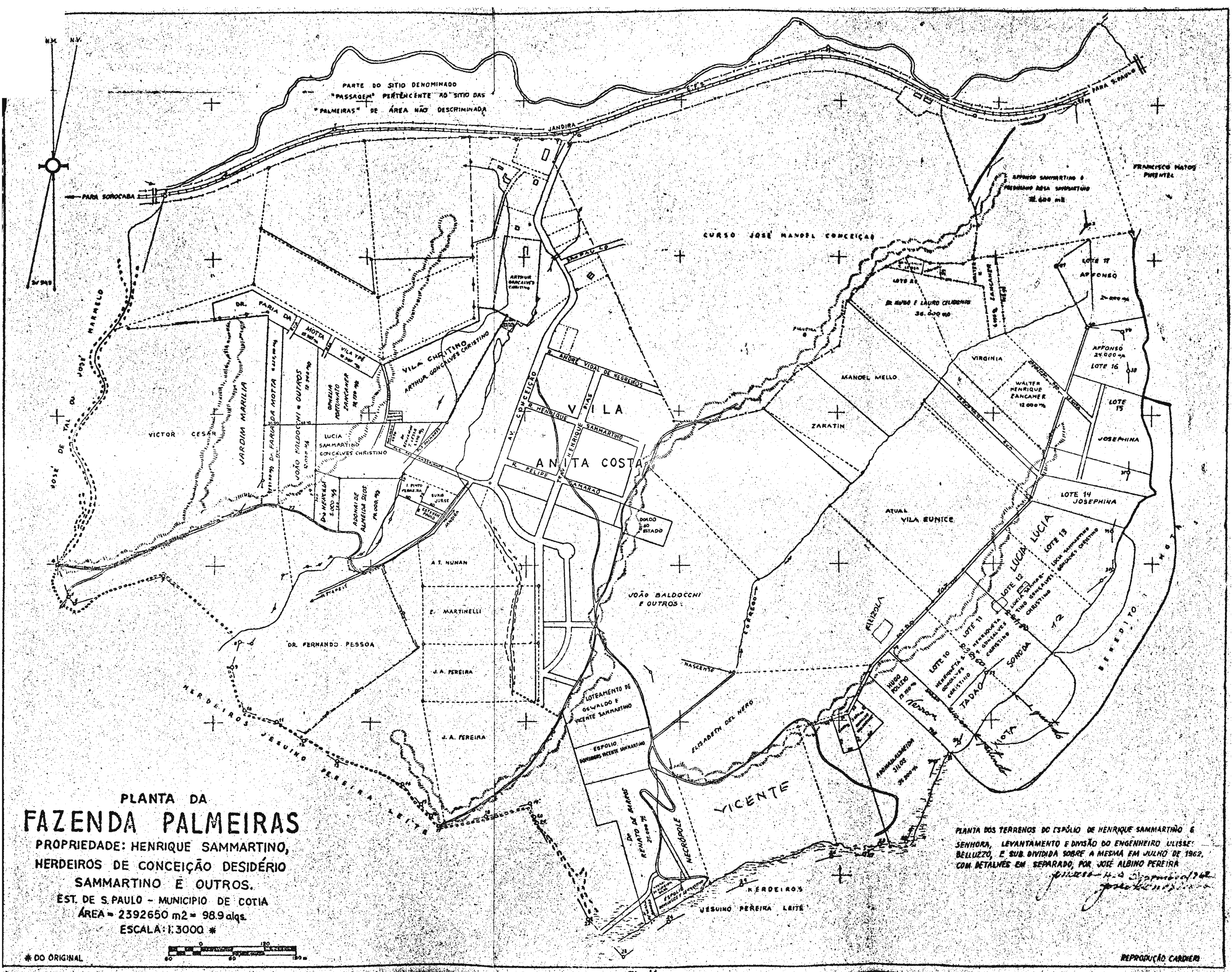


Dentro da Sub-Regiāo Norceste o municỉplo com malor in dice de crescimento, no periodo 60-70, fol precisamente o de Jandira. De fato, o crescimento fol acentuado, pols se na déca da 50-60 o Indice fol de 38,778, na ültima (60-70), elevou-se pa ra 510,168. Estima-se em vinte e um mil e vinte e um $o$ número de habitantes para 1976, portanto um aumento de 169,008 , em a penas seis anos.

Nem por isso Jandira é um caso excepcional em sua região. A explosão demográfica também é localizada nos municí plos de Carapicuiba e Itapevi, que apresentaram, respectivamen te, as taxas de aumento de $268,77 \%$ e 170,768 , no último de cênio (60-70). Já Pirapora do Bom Jesus apresenta índice que, comparativamente, permitem afirmar que seu desenvolvimento po pulacional é moderado.

Quanto à população das demals unidades continua se desenvolvendo gradativamente.Porém : se se compararem os dados dos periodos 50-60 e 60-70, perceber-se-á uma evidente desace leração no rítmo do processo. E o caso de Osasco, por exemplo, cujo Indice inicial, 156,688, decaiu, em 60-70, para 143,988. Este fato é ainda mais expressivo em Barueri; se em 50-60, o município teve sua população aumentada em 270,548 , nos dez anos seguintes o aumento foi de apenas 126,758 .

Algo semelhante sucede-se em Cajamar, com Indice de 70,318 na década de clnqtienta, decaindo para 62,168 no período de 60-70. E, por fim, surge Santana do Parnalba. Seu desenvol vimento populacional, que já era baixo dentro da região $(19,538)$ em 50-60, no decênto seguinte tornou-se quase insignificante com seus 3,518 . 
De qualquer mānèira, èn hủnètós absolutós, à pópulação de todos os muñicípios na sub-Régíão Noroeste da Grande São Báulo vêm séndo mulziplieada de àno para ano. Cómo aécorrên éia desse fato, tềm surgldo alteráções quantitațivas no segmen

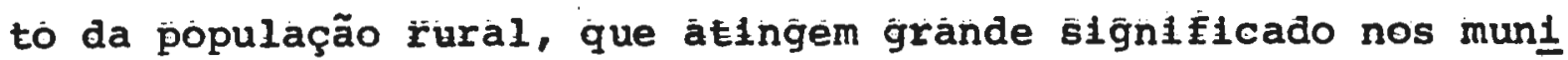
cilpios de rápiao creścimento.

Anàlisando-se a problemática da zona rural, podé-se dí vidir ás unidades politicas na sub-Região Noroeste en doss grupos.

No primeiro, encontram-se os municipios inscritos em uma vasta área já conurbada, com altos indices de crescimento populacional e os consequentes problemas urbanisticos. Parale lamente, sua população rural val ou fol diminuindo, a ponto de desaparecer. Em decorrêncla, as zonaś urbanas vêem suas precâ rias estruturas postas em cheque, sem que os hovos e os antí gos habitantes possam satisfazer suas ininimas condições de ví da.

Nà Sub-Régião Noroeste os municípios de Itapevi, Cara picuiba, Osasco e Jandira foram os que mais se sobressairam como unidades cujo crescimento populacional pode ser considera do explosivo. São esses mesmos municípios que jã não contam mais com população rural no Censo Demográftco de 1970 , fato es te constatado no Quadro VII.

No segundo grupo, Pirapora do Bom Jesus apresentou um considerável aumento da população rural no periodo 50-60;porém na década seguinte, houve um pequeno decréscimo, o que não. Im pede que essa população seja significativa, principalmente se comparada com o todo. 
Tambèm em Santana de Parnaíba e Cajamar encontra-se contingentes rurais bastante representativos, superando mesmo a população citadina. o primeiro dos municipios conta com 58,738 de seus habitantes instalados no campo, e o segundo 60,178 .

\section{QUADRO VII}

Distribuição Percentual da População Rural e Urbana

\begin{tabular}{|l|r|r|r|r|r|r|}
\hline \multicolumn{1}{|c|}{ Municipios } & \multicolumn{2}{|c|}{ Rural950 Urbana } & \multicolumn{2}{c|}{ Rural Urbana } & \multicolumn{2}{c|}{ Rural Urbana } \\
\hline Osasco & $*$ & & 68,91 & 31,09 & - & 100,00 \\
Itapev1 & 73,38 & 26,62 & 54,53 & 45,47 & - & 100,00 \\
Jandira & 57,29 & 42,71 & 45,77 & 54,23 & - & 100,00 \\
Santana de Parnaiba & 76,61 & 23,39 & 23,03 & 27,97 & 58,73 & 41,27 \\
Barueri & 45,21 & 54,79 & 14,40 & 85,60 & 3,78 & 96,22 \\
Cajamar & 67,35 & 32,65 & 71,70 & 28,30 & 60,17 & 39,83 \\
Carapicuiba & - & 100,00 & 1,74 & 98,26 & - & 100,00 \\
Pirapora B. Jesus & 38,90 & 61,10 & 58,20 & 41,80 & 52,20 & 47,80 \\
& & & & & & \\
\hline
\end{tabular}

(*) Não se obteve dados.

Fonte: Censo Demogrāfico

\subsection{Crescimento Vegetativo}

Para se constatar as causas do aumento populacio nal de Jandira, foram analisados os quadros VIII $e x$ re lativos ao crescimento vegetativo e à naturalidade.

Os dados de primeiro quadro foram obtidos do movi mento do Registro Civil ro Estado de são Paulo, e os do segundo, em pesquisa domiciliar feita por amostragem. 


\section{QUADRO VIIII}

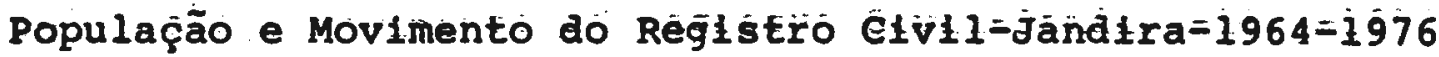

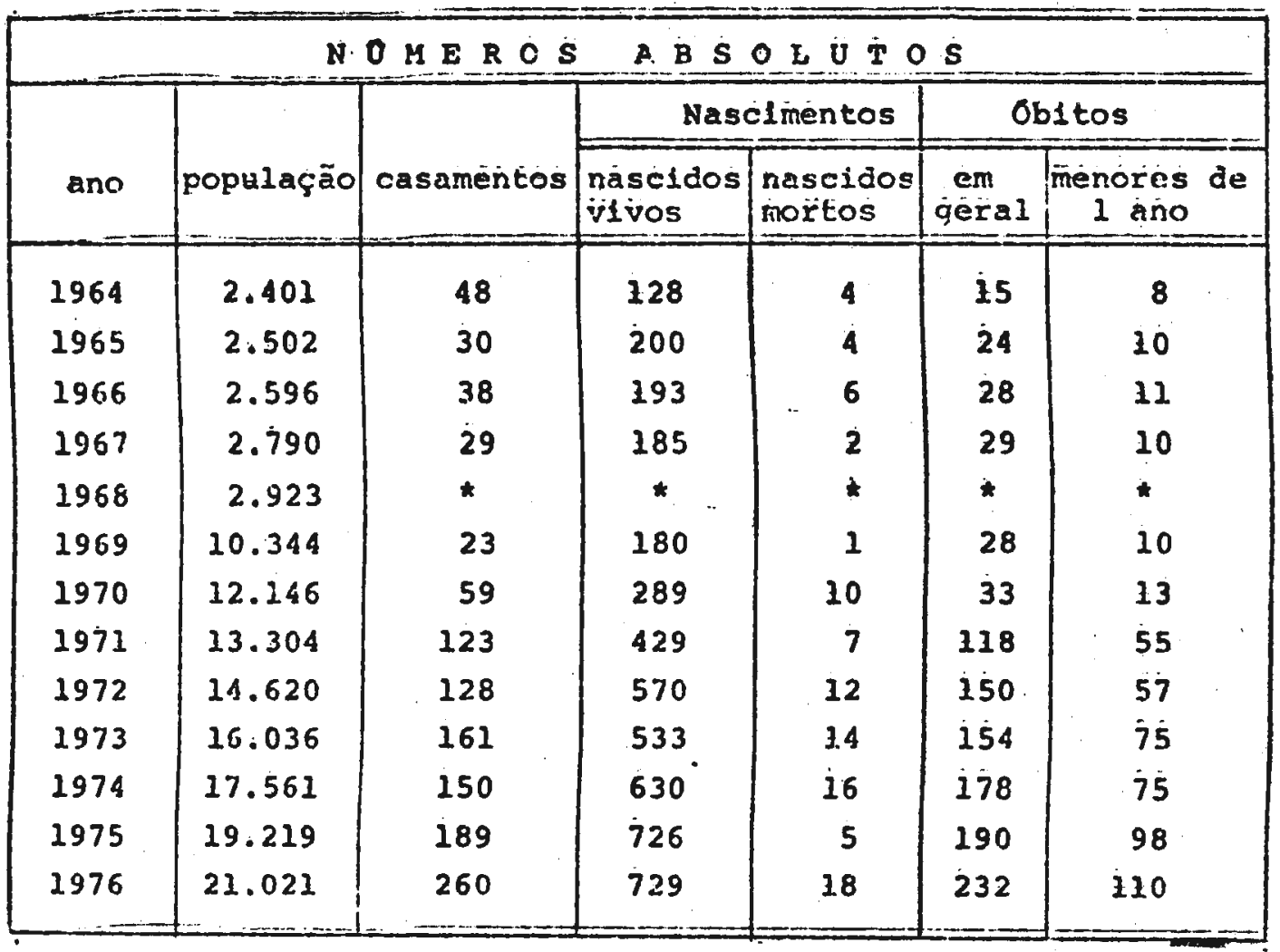

(*) Não se obteve dadós pàra 1968

Fónte: Estudos e Pesquisas Movimento do Reǵistrió Civil no Estado de são Paulo.

Observa-se claramente que o crescimento vegetativo é muito inferior ao total acumulado da pópulação. Cónsiderando se 1964 como ano base, com dols mil quatrocentos e um habitan tes, somando-se-lhe o total de nascidos, já subtraidos os mor tos do perído 1965 a 1976, ter-se-1a clnco mil novecentos e um individuos. No entanto, a população oficial é de vinte e um $\mathrm{mll}$ e vinte e um habitantes. Logo, conclui-se que a imigra cão supera de longe o crescimento vegetativo, apesar do movimen to emigratório também existente.

Em pesquisa domic1l1ãr-1974, connstatou=se que : àpenas

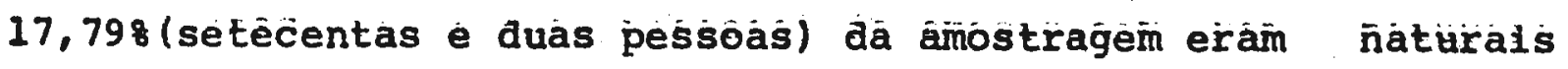
do municipio. 


\subsection{O Papel da Migração}

Há muitos fatores que levam $O$ individuo a abando nar sua cidade natal, quase sempre à procura de melhores condiçōes de vida. Entre eles podem-se salientar a busca de emprego, o atendimento hospitalar e a continuação dos estudos como elementos de motivação. o polo principal e inicial para esse processo é, frequentemente, a cidade de são Paulo. Ocorre, porém, que as dificuldades que essa cidade apresenta para fixação de residência, ocasionadas pelo alto preço do aluguel e dos imóveis, levam os migran tes a procurarem a periferia de conurbação.

Como foi visto anteriormente, a migração na ärea em estudo tem um papel muito importante, pois os imigran tes perfazem um total de 82,218 da amostragem de residen tes-1974.

Identificou-se essa procedência, analisando-se dois tipos de dados. 0 primeiro , tem como referência o estado de origem e os três últimos, locais de residência do m1 grante. o segundo baseia-se apenas na ültima cidade na qual tenha residido.

o quadro IX e a F1g. XXII (Procedência: origem e os três últimos locais de residência) visualizam detalhes do tipo de trajeto pexcorrido pelo migrante (33).

(33) No texto, é dificil exprimir-se de uma forma não can sativa para o leitor, uma vez que a pesquisa neste as pecto foi orientada de modo a acompanhar cada Indivi duo. 
QUADRO IX

Procedência: origem $e$ os três ültimos locals de residêncla'

\begin{tabular}{|c|c|c|c|c|c|c|c|c|c|c|c|c|c|c|c|c|c|c|c|}
\hline & \multicolumn{2}{|c|}{ a.2tal } & \multicolumn{2}{|c|}{ DLre:0 } & \multicolumn{4}{|c|}{ Uma c1dace } & \multicolumn{5}{|c|}{ Cuas cleades } & \multicolumn{6}{|c|}{ Irés Clinces } \\
\hline Est. & $n 8$ & 1 & no & 1 & $p \cdot$ & $\mathrm{np} *$ & total & 1 & $p$ & Lpp & $\begin{array}{r}2 \\
n p\end{array}$ & $\begin{array}{l}\text { to } \\
\text { tal }\end{array}$ & 1 & P & $\begin{array}{l}1 \mathrm{p} \\
2 \mathrm{np}\end{array}$ & $3 n$ & $\begin{array}{l}2 p \\
2 r p\end{array}$ & $\begin{array}{l}\text { to } \\
\text { tal }\end{array}$ & 1 \\
\hline S? & 1.596 & 52,09 & 211 & 64,22 & 427 & 27 & 154 & 43,16 & 170 & 32 & 4 & 203 & 46,50 & 97 & 3 & 3 & 21 & 126 & 38,18 \\
\hline .46 & 104 & 12.42 & 151 & 10,65 & 106 & 35 & 141 & 23,43 & 27 & 25 & 13 & 53 & 12.50 & 32 & 13 & ${ }^{\circ}$ & 6 & 57 & 17,27 \\
\hline $3 \mathbf{A}$ & 303 & $9,3: 1$ & 83 & 5,85 & 5121 & 15 & 136 & 12,93 & 30 & 7 & 10 & $\$ 7$ & 10.63 & 24 & 7 & 1 & 5 & 37 & 11.21 \\
\hline$? \varepsilon$ & 209 & 0.12 & 58 & 1.09 & 71 & 24 & 95 & 9,03 & 13 & 8 & 5 & 26 & 5,91 & $2:$ & 3 & 2 & 4 & 30 & 9,09 \\
\hline$P R$ & 190 & 5,84 & 95 & 6.69 & 14 & 18 & 62 & 5.89 & 7 & 8 & 6 & 21 & 4.77 & 1 & 3 & 3 & 3 & 12 & 3.54 \\
\hline AL & 141 & 1,42 & 55 & 3.37 & 11 & 14 & 55 & 5,23 & 12 & 7 & 3 & 22 & 5.00 & 5 & - & 4 & 3 & 12 & 3,64 \\
\hline$c \varepsilon$ & 48 & 1.47 & 16 & 1,12 & 7 & 9 & 26 & 1,52 & - & 6 & 1 & 7 & 1,59 & 4 & 5 & - & - & 9 & 2.73 \\
\hline$x \in t$ & 247 & 7.53 & 50 & 3,52 & 79 & 14 & 93 & 8,84 & 27 & 21 & 9 & 57 & 12,95 & 33 & 4 & - & 10 & 47 & 14,24 \\
\hline $3 / x$ & 15 & 0.46 & - & - & $1-$ & - & - & - & - & - & - & - & - & -1 & - & - & .- & - & - \\
\hline ent. & 3.256 & 100.00 & 1.419 & 100,00 & 896 & 156 & 2.052 & 100,00 & 276 & 123 & 51 & 140 & 100,00 & $217 \mid$ & 33 & 23 & 57 & 330 & 100.00 \\
\hline
\end{tabular}

(*) Outros = inclusive estrangeiros

(*) p $\mathrm{p}$ paulista

(*) np = não paulista

Fonte: Questionảrio Domiciliar 1973/74

Após apurado o local de nascimento da pessoa, a preocupação posterior fol a de saber como chegou a Jandi ra. Verificou-se que apenas 43,588 (mil quatrocentas e dezenove)pessoas da amostra vieram diretamente, e destes 64,218 do total, do prōprio Estado de são Paulo. Acompa nhou-se o trajeto felto pelos que passaram por outras $c \underline{1}$ dades antes de fixarem residência no município. No caso daqueles que passaram por apenas uma cidade, quantificou se:

1. passaram por uma cidade paulista;

2. passaram por uma cidade não paulista.

Dentro dessas alternativas hã que se conside rar ainda os que passaram por duas e por três cldades. 


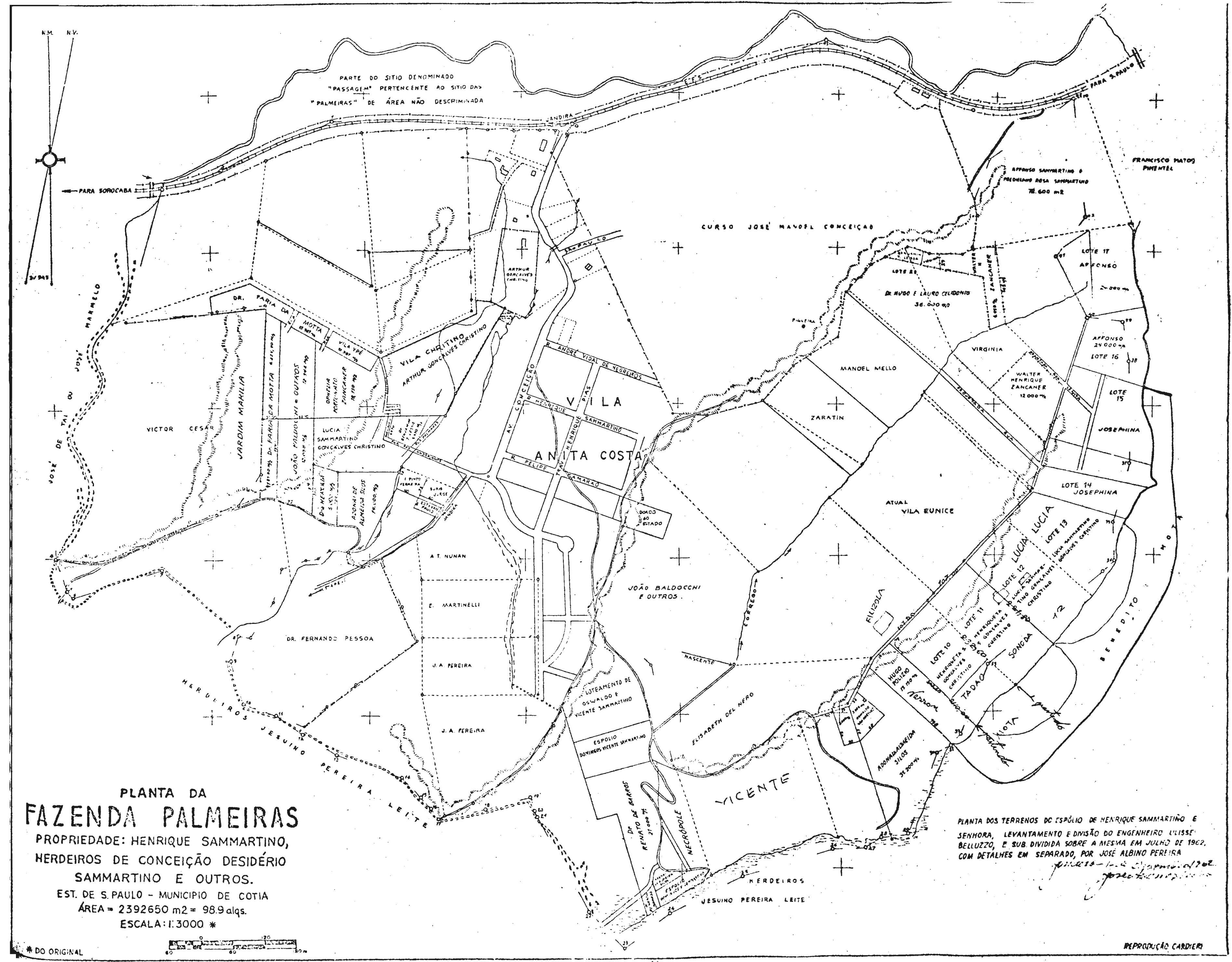


Interessante registrar que em todos os casos à malor porcentagem coube aos que passaram por cidades pau listas e, quanto à procedêncla direta, a maioria também de paulistas, seguidos de mineiros, paranaenses e balanos.

A naturalidade dos habitantes de Jandira fol vis ta sob três aspectos conforme os quadros X, XII e XIII e as figuras XXIII, XXIV e XXV.

\section{QUADRO $\quad x$}

Naturalidade dos Habitantes de Jandira

\begin{tabular}{|c|c|c|c|c|c|c|c|c|}
\hline Locals & $\begin{array}{l}\text { to } \\
\text { tal }\end{array}$ & 8 & $\begin{array}{l}\mathrm{Ru} \\
\mathrm{r} \text { a } 1\end{array}$ & 8 & Urbana & 8 & $S / R$ & 8 \\
\hline São Paulo & 2.398 & 60,59 & 569 & 23,74 & 1.808 & 75,39 & 21 & 0,87 \\
\hline Minas Gerais & 404 & 10,21 & 251 & 62,13 & 142 & 35,15 & 11 & 2,72 \\
\hline Bahia & 303 & 7,15 & 171 & 56,44 & 117 & 38,61 & 15 & 4.95 \\
\hline Pernambuco & 209 & 5,28 & 133 & 63,64 & 75 & 35,88 & 1 & 0,48 \\
\hline Paraná & 190 & 4,80 & 99 & 52,11 & 88 & 46,31 & 3 & 1,58 \\
\hline Alagoas & 144 & 3,64 & 76 & 52,78 & 64 & 44,44 & 4 & 2,78 \\
\hline Cearā & 48 & 1,21 & 29 & 60,42 & 17 & 35,41 & 2 & 4,17 \\
\hline Outros Estados & 198 & 5,00 & 90 & 45,45 & 103 & 52,03 & 5 & 2,52 \\
\hline Estrangeiros & 49 & 1,24 & 8 & 16,33 & 32 & 65,30 & 9 & 18,37 \\
\hline Sem Resposta & 15 & 0,38 & & & & & & \\
\hline Totais & & 00,00 & 1426 & 36,03 & 2.446 & 61,80 & 71 & 1,80 \\
\hline
\end{tabular}

Fonte: Questionário Domiciliar 1973/74

Verifica-se que a maioria da população de Jandira nasceu no próprio Estado de São Paulo.

Se a parcela constituida por paulistas passar a ser vista como um todo, observa-se que os naturais da pró pria Jandira representam apenas 29,358 . 
Esses paulistas são originários, principalmente , da zona urbana, reflexo do fato de ser o estado bandelran te aquele onde a urbanização sobrepuja, hoje, em larga es cala, à ruralização populacional. Assım, da parcela de entrevistados que declararam ter nascido no Estado de são Paulo, 75,398 procedem da zona urbana.

\section{QUADRO XI}

Porcentagem da População Urbana para Alguns Estados Brasileiros

\begin{tabular}{|l|r|r|r|r|}
\hline \multirow{2}{*}{ Estados } & \multicolumn{2}{|c|}{1960} & \multicolumn{2}{c|}{1970} \\
\cline { 2 - 5 } & Populaçāo & Urb.8 & População & Urb.8 \\
\hline São Paulo & 8.149 .979 & 62,81 & 14.275 .660 & 80,31 \\
Minas Gera1s & 3.964 .580 & 39,80 & $6.063,234$ & 52,73 \\
Bahía & 2.083 .716 & 34,78 & 3.090 .360 & 41,16 \\
Pernambuco & 1.856 .689 & 44,88 & 2.813 .907 & 54,46 \\
Paranā & 1.327 .982 & 30,91 & 2.501 .660 & 36,06 \\
Cearā & 1.124 .829 & 33,70 & 1.781 .292 & 49,79 \\
Alagoas & 428.228 & 33,69 & 632.397 & 39,78 \\
\hline
\end{tabular}

Fonte: Censo Demográfico 1960/1970

Como a ma1or parte da população residente em Jand 1 ra é natural do Estado de são Paulo, a importância e o pe so do processo de urbanização refletem-se no fluxo migra tório. Nos demais Estados, o fenômeno urbano é menos a centuado, o que explica o predominio da origem rural dos migrantes não paulistas. (VIde Quadro $X I$ ). 


\section{QUADRO XII}

Naturalidade: Estado de são Paulo

\begin{tabular}{|c|c|c|c|c|c|c|c|c|}
\hline Locals & Total & 8 & $\begin{array}{l}\mathrm{Ru} \\
\mathrm{ra} \mathbf{a}\end{array}$ & 8 & $\begin{array}{l}\text { Urba } \\
\text { na }\end{array}$ & 8 & SR & 8 \\
\hline 1.Grande São Paulo & 1.469 & 61,26 & $\otimes$ & 5,43 & 1.381 & 94,02 & 8 & 0,55 \\
\hline 2.Litoral & 8 & 0,34 & - & - & 8 & 100,00 & - & - \\
\hline 3.Vale do ParaIba & 26 & 1,08 & 9 & 34,61 & 16 & 61,54 & 1 & 3,85 \\
\hline 4.Sorocaba & 199 & 8,30 & 108 & 54.41 & 89 & 45,10 & 2 & 0,49 \\
\hline 5.Campinas & 78 & 3,25 & 30 & 38,46 & 45 & 57,69 & 3 & 3,85 \\
\hline 6. Ribeirão Preto & 125 & 5,21 & 55 & - & 69 & 55,45 & 1 & 0.99 \\
\hline 7.Bauru & 88 & 3,67 & 66 & 75,28 & 22 & 24,72 & - & - \\
\hline $\begin{array}{l}\text { 8.S.José do Rio } \\
\text { Preto }\end{array}$ & 40 & 1,67 & 29 & 72,31 & 11 & 27,69 & - & - \\
\hline 9.Araçatuba & 64 & 2,67 & 30 & 46,57 & 34 & 53,43 & - & - \\
\hline $\begin{array}{l}\text { 10. Presidente } \\
\text { Prudente }\end{array}$ & 95 & 3,96 & 34 & 35,64 & 60 & 63,36 & 1 & 1,00 \\
\hline 11.Maril1a & 168 & 7,01 & 94 & 55,69 & 71 & 42,61 & 3 & 1,70 \\
\hline . não especificou & 38 & 1,58 & 34 & 89,48 & 2 & 5,26 & 2 & 5,26 \\
\hline Totais & 2.398 & 100,00 & 555 & 23,38 & 1.806 & 75,86 & 19 & 0,76 \\
\hline
\end{tabular}

Fonte: Questionārio Domiciliar 1973/74

As origens são multo diversificadas no próprio Esta do de são Paulo e,representadas pelas onze reqiōes adminis tratıvas,a Grande São Paulo ocupa lugar de destaque. Um dos fatores que explicam isto é ser o municlpio de Jandira periferia deste grande centro, o qual, jā, saturado, faz "Inchar" as äreas urbanas dos municlpios ao seu redor (34).

(34) Paul Singer e colaboradores in Recursos Humanos da Grande São Paulo, Vol. I 1971 p. 58, tratando da di nâmica da população abordou este aspecto de crescimeñ to da periferia. 


\section{QUADRO XIII}

Naturalladed Grande São Paulo

\begin{tabular}{|c|c|c|c|c|c|c|c|c|}
\hline Locais & Total & 1 & $\begin{array}{l}\mathrm{Ru} \\
\mathrm{ral}\end{array}$ & 8 & Urbana & 3 & Ns & 8 \\
\hline JandIIa & 702 & 47.78 & 28 & 3,98 & 671 & 95,59 & 3 & 0,43 \\
\hline São Paulo & 466 & 31,71 & 8 & 1,72 & 458 & 98,28 & $=$ & - \\
\hline Osasco & 141 & 9,59 & 7 & 4,96 & 134 & 95,04 & $=$ & $=$ \\
\hline Baruer1 & 35 & 2,37 & 4 & 11,43 & 31 & 88,57 & $=$ & - \\
\hline Itapev1 & 33 & 2,24 & 6 & 18,18 & 27 & 81,82 & $=$ & $=$ \\
\hline $\cot 1 a$ & 15 & 1,02 & 12 & 80,00 & 3 & 20,00 & - & - \\
\hline Carapiculba & 15 & 1.02 & - & - & 15 & 100,00 & $=$ & - \\
\hline São Bernardo do Campo & 9 & 0,61 & - & - & 9 & 200,00 & - & - \\
\hline Guarulhos & 6 & 0.48 & - & - & 6 & 100,00 & $=$ & - \\
\hline Santo Andrē & 6 & 0,40 & 1 & 16,67 & 5 & 83,33 & $=$ & $=$ \\
\hline gerraz de Vasconcelos & 3 & 0.20 & - & - & 3 & 100,00 & $=$ & - \\
\hline Vairiporã & 4 & 0,27 & - & - & $=$ & - & 4 & 100,00 \\
\hline S. Caetano do Sul & 7 & 0,47 & - & - & 7 & 200,00 & - & - \\
\hline Itapecerica da Serra & 3 & 0,20 & 1 & 33,33 & 2 & 66,67 & - & $=$ \\
\hline Pranco da Socha & 2 & 0,13 & 1 & 50,00 & 1 & 50,00 & $=$ & - \\
\hline Yauá & 1 & 0,09 & - & - & 1 & 100,00 & - & $=$ \\
\hline suzano & 1 & 0,09 & - & - & 1 & 100,00 & $=$ & - \\
\hline Embu & 1 & 0,09 & - & - & 1 & 100,00 & $=$ & - \\
\hline Juquitiba & 1 & 0,09 & - & - & 1 & 100,00 & - & $=$ \\
\hline Calerias & 1 & 0,09 & - & - & 1 & 100,00 & - & - \\
\hline Pirapora do Bom Jesus & 5 & 0,34 & 5 & 100,00 & - & $=$ & - & - \\
\hline Santana do Parnalba & 11 & 0.74 & 7 & 63,64 & 3 & 27,27 & 1 & 9,09 \\
\hline Diadema & 1 & 0,07 & - & - & 1 & 100,00 & - & - \\
\hline Totals & 1.469 & 100,00 & 80 & 5,45 & 1.381 & 94,01 & 8 & 0,54 \\
\hline
\end{tabular}

Fonte: Questionärlo Domiciliar 1973/74

A Reglão da Grande São Paulo é a naturalidade de 61,268 da população-amostra de Jandira. Deste contingen te, 47,788 são naturals da própria cldade, 31,718 de são Paulo e 9,59 de osasco. Outros municípios participam, mas com porcentagens reduzidas. 
Retornando ao Quadro $X$, verifica-se que

outros Estados, em relação a são Paulo, surgem com porcen tagens menores. O mais significativo è Minas Gera1s, com Indice de 10,218, sendo que 62,138 dos migrantes minelros nasceram no campo. Acredita-se que eles se distribuiram por diversos municíplos da Grande são Paulo, pols const 1 tuem 8,358 da população total de Baruer1 (35) e 13,158 da população do município de Embu (36).

Os contingentes das demais unidades da Federação são bem pouco numerosos, representando, em conjunto, em total de 28,088 dos migrantes.

Os habitantes oriundos do estrangeiro formam ape nas 1,248 da população, ou seja, quarenta e nove pessoas da amostragem. O Japão estã presente com dez pessoas $(0,26)$, a Espanha com sels $(0,158)$, Portugal com catorze $(0,368)$, Suriname com quatro $(0,118)$, Ant1lhas Holandesas com três $(0,088)$ e União Soviética e Peru com dois $(0,068)$ cada un.

Os quatro ültimos paises não são zonas de emigra ção tradicional, de modo que a presença de tais imigran tes em Jandira deve ser vista como episódica. As porcen tagens apresentadas restringem-se, multo provalmente, ape nas ao campo da amostragem, não se estendendo ao global da população da cidade.

Por ültimo, encontrou-se tambēm um indivíduo de cada um destes paises: Cuba, Bolívia, Siria, Libano, Itā

(35) Tércia C. CAVALCANTE. - "Barueri e sua particıpaçãono Conjunto da Faixa Periférica da Metrópole Paulis tana", SP, FFLCH. da USP. p.14

(36) Maria Niedja Leite de OLIVEIRA - "Embu e sua particl pação no Conjunto da Faixa Periférica da Metrópole Paulistana", SP, FFLCH. da USP.P.33 
11a, Panamá e Argentina, significando cada um deles $0,02 \%$. Talvez seja válida uma observação Inversa à do paráarafo anterior. De fato, por serem Sirla, Libano e Itálla paises que têm tradição como centros emigratórios, o en contro de apenas um individuo dessas naçōes não deve re presentar, porcentualmente, a realidade do universo popu lacional jandirense.

Em análise anterior, os dados foram trabalhados considerando-se a origem-naturalidade dos habitantes-amos tra. Analisar-se-á em seguida a última cidade onde mo rou o entrevistado (37)

QUADRO XIV

Procedência: último local de residência

\begin{tabular}{|l|r|r|}
\hline \multicolumn{1}{|c|}{ Estado } & Total & \multicolumn{1}{|c|}{} \\
\hline São Paulo & 2.488 & 76,44 \\
Paraná & 222 & 6,82 \\
Minas Gerais & 187 & 5,74 \\
Bahia & 104 & 3,20 \\
Pernambuco & 73 & 2,24 \\
Alagoas & 57 & $-1,75$ \\
Rio de Janeiro & 37 & 1,14 \\
Mato Grosso & 28 & 0,86 \\
Ceará & 19 & 0,58 \\
Outros & 91 & 2,80 \\
Sem resposta & 15 & 0,46 \\
Totals & 3.256 & 100,00 \\
\hline
\end{tabular}

Fonte: Questionário Domicillar 1973/74

(37) Incluso os naturais da cidade que vieram direto. 
A anālise do Quadro XIV permite observar que 76,448 dos Imigrantes procedem de municipios do Estado de sãa Paulo, não tendo sido considerado o de Jandira.

o Estado do Paraná, que ocupa o quinto lugar quan to à origem dos entrevistados, passa para o segundo lugar no que se refere à procedência.

E de se supor que a estrutura econômica desta un dade federativa atraía as atençōes da massa migratória. Na fase seguinte, as expectativas não são correspondidas, levando as pessoas envolvidas no processo a se interessarem por áreas mais industrializadas. Isto talvez expli que a procedência paranaense dos 6,828 de imigrantes.

- Estado de Minas Gerais surge com 5,748. O Qua dro $\mathrm{X}$ indica a presença de quatrocentos e quatro mineiros na amostragem. Entretanto, apenas cento e oitenta e sete pessoas procedem diretamente desse Estado, numa clara evi dência de que uma parte considerável de mineiros residiu anteriormente em outras partes do pais.

E semelhante o caso de balanos, pernambucanos e alagoanos uma vez que a quantidade de pessoas que afirma ram ter nascido nos Estados respectivos não coincide com os números referentes à procedência (vide Fig. XXVI).

Como o Estado de São Paulo pesa significativamente no cômputo geral, é interessante também verificar a procedência por Regiōes Administrativas. 


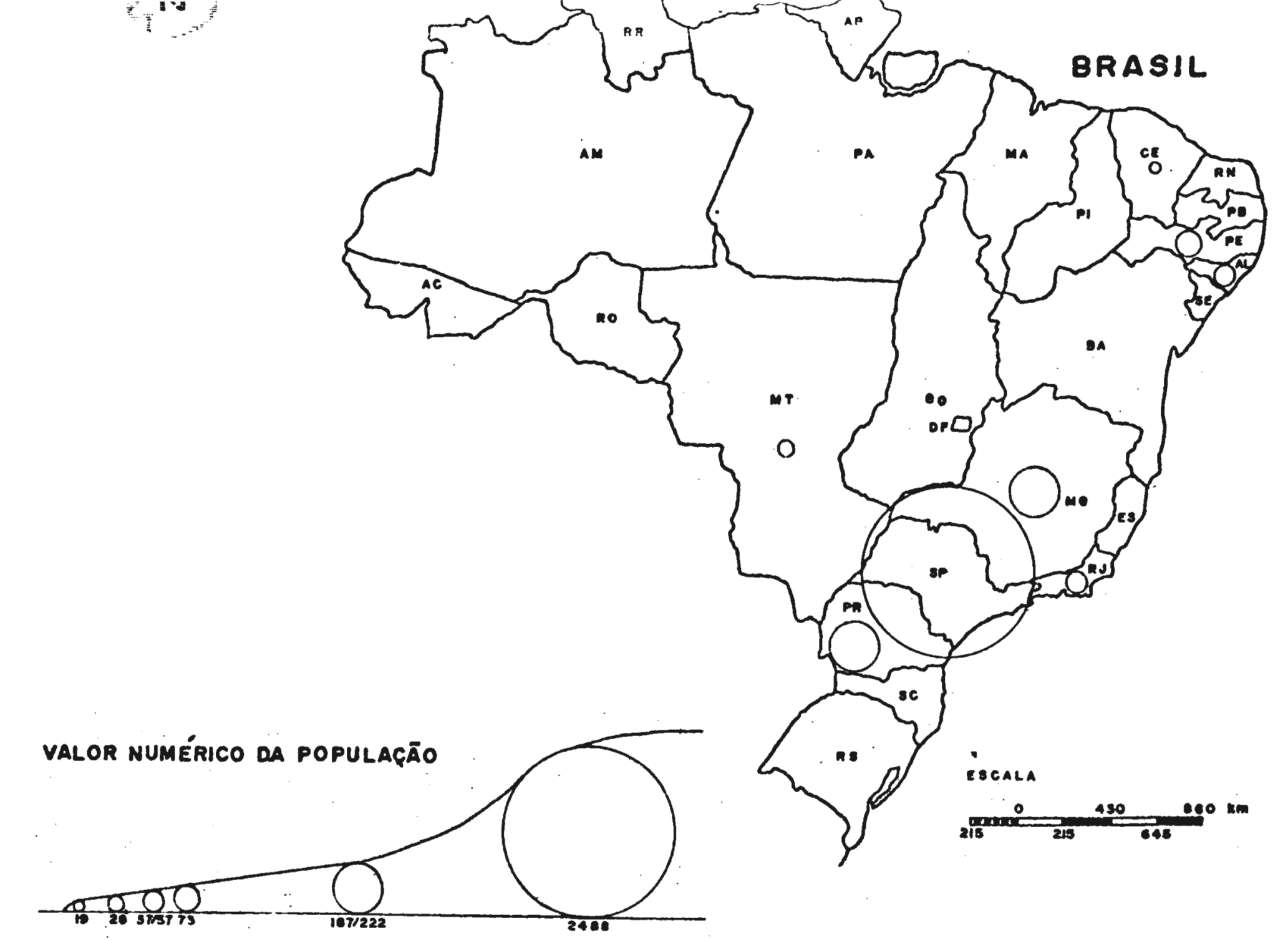

FONTE: QUESTIOMAGIO DOMICILIAE IDTS/TO ongamizadoz F. L.e. Cakoiear 
QUADRO XV

Procedêncla dos Imigrantes: Estado de são Paulo

\begin{tabular}{|l|r|r|}
\hline \multicolumn{1}{|c|}{ Regiōes } & Total & \multicolumn{1}{c|}{8} \\
\hline Grande são Paulo & 1.753 & 70,46 \\
Sorocaba & 196 & 7,88 \\
Marilia & 151 & 6,07 \\
Presidente Prudente & 116 & 4,66 \\
Bauru & 60 & 2,41 \\
São Jose do Rio Preto & 54 & 2,17 \\
Camplnas & 49 & 1,97 \\
Araçatuba & 46 & 1,85 \\
Ribelrão Preto & 41 & 1,65 \\
Vale do Paraiba & 11 & 0,44 \\
Litoral & 5 & 0,20 \\
Não especificada & 6 & 0,24 \\
Total & 2.488 & 100,00 \\
\hline
\end{tabular}

Fonte: Questionārio Domiciliar 1973/74

o Quadro XV e a Fig. XXVII delxam flagrante o des taque da Grande são Paulo sobre as demais regiōes.

A onda migratōria alcança, inicialmente, são Pau lo e/ou as cidades mals próximas. Estes aglomerados, se por um lado oferecem certas vantagens, por outro, apresentam problemas que não apenas anulam aquelas, como alnda são de tal magnitude para as classes economicamente menos favore cidas, que não resta aos individuos atingidos nada mais do que se mudar para outras comunidades, mesmo assim não mu1 to distantes da metrōpole, visando não dificultar o acesso aos locais de trabalho. 
'ROCEDÉNCIA: ORIGEM E OS TAÊS ÚLTIMOS LOCAIS OE RESIOËMCIA

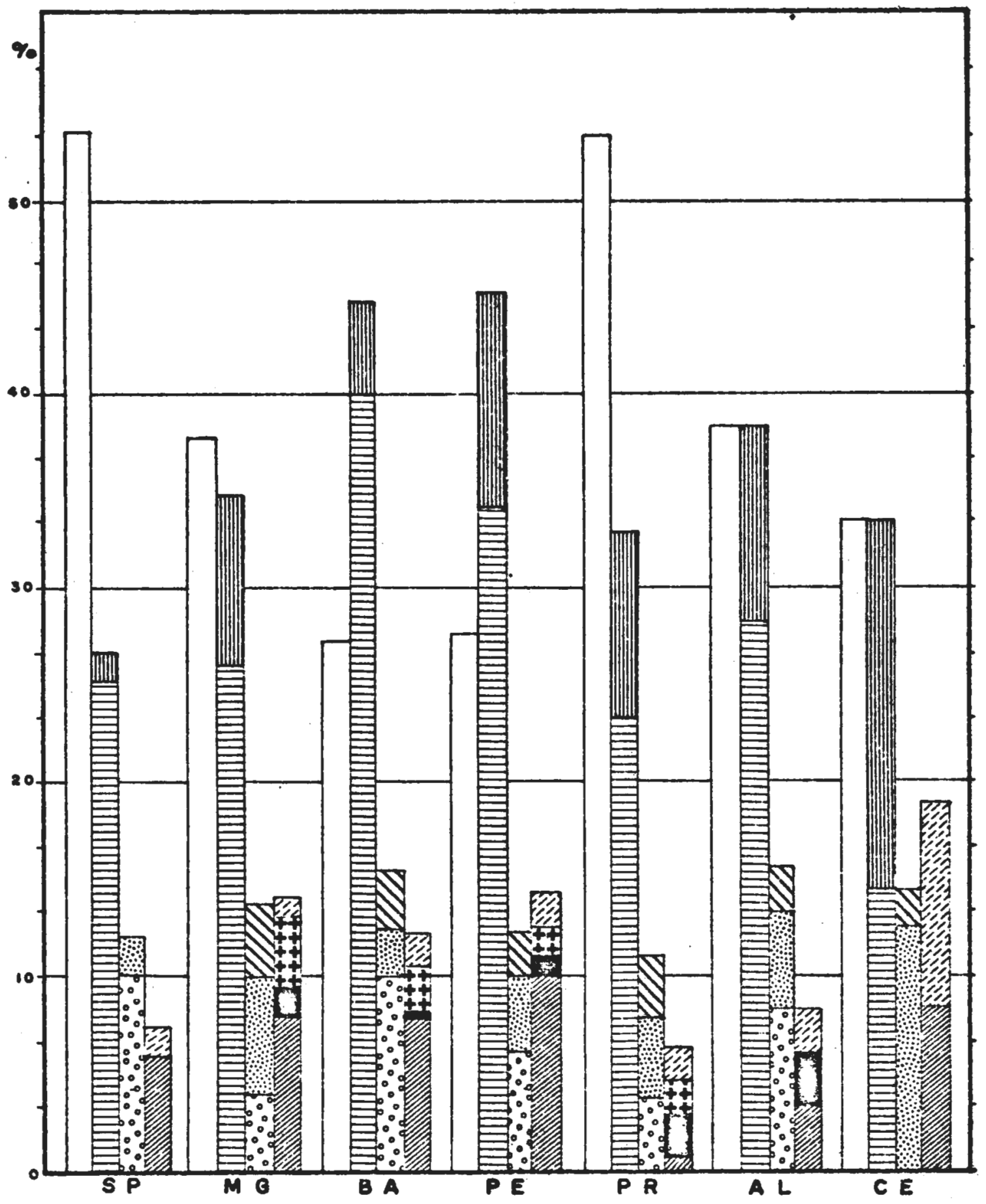

LEGENDA

$\square$ oineto

E

UMA CIDADE PAULIETA

IIIIIIII

uma cidade hio PaUlieta

60:

dUAS CIDADES maUListas

NIV

UMA cioade PAULISTA E UMA nRo PaULIOTA

in

duAs cioades máo paulietas

this cionde paulistas

$\rightarrow$

4+4

TAL CIDADE mXo paULIETAS

避
uMA CIOAdE PaULISTA duAs não pauLIstae

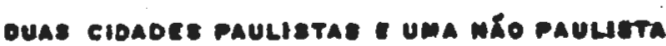

Ponte: oues rionino oomering $1073 / 74$

OREAMIZADO: R.L.C.CAMDSEAI

Des.: cacoire 


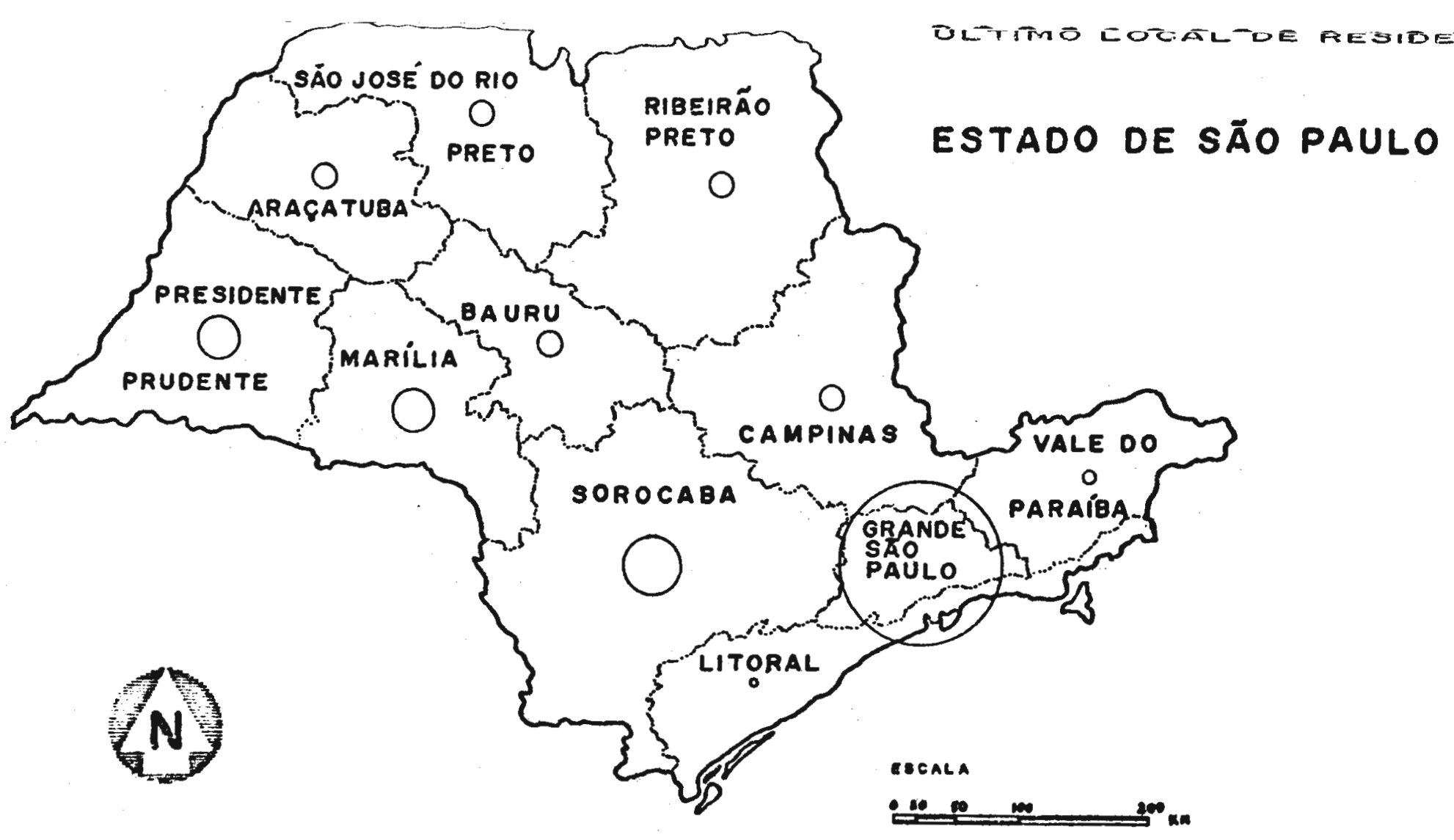

VALOR NUMÉRICO DA POPULACAOO

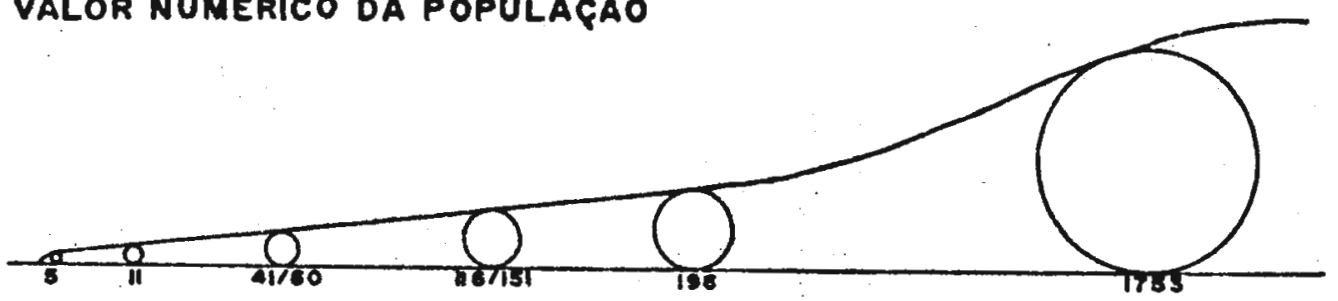

PONTE: OUE BTIOMÁRIO DOMICILIAA 18 TS/7A OROAMIZADO: F.L. C. CARDIEAI 
Possivelmente o malor problema seja, neste caso, - representado pelo preço dos aluguēis. Mas não se pode esquecer, também, o desejo de adquirir casa própria, dese jo esse que pode ser satisfeito com malor facllidade nos municípios periféricos. Dessa maneira, entende-se porque mals de dols terços, ou seja, 70,468 dos migrantes são procedentes da Grande São Paulo.

\section{QUADRO XVI}

Procedência dos Imlgrantes: Grande São Paulo

\begin{tabular}{|l|r|r|}
\hline \multicolumn{1}{|c|}{ Municlpio } & Total & \multicolumn{1}{|c|}{8} \\
\hline São Paulo & 964 & 55,01 \\
Osasco & 234 & 13,35 \\
Itapev1 & 163 & 9,30 \\
Baruer1 & 127 & 7,24 \\
Plrapora do Bom Jesus & 91 & 5,19 \\
Caraplculba & 64 & 3,65 \\
Cotia & 24 & 1,37 \\
Santana do ParnaIba & 22 & 1,25 \\
Santo André & 14 & 0,80 \\
São Caetano do Sul & 12 & 0,68 \\
Guarulhos & 10 & 0,57 \\
Maüa- & 9 & 0,51 \\
Ferraz de Vasconcelos & 6 & 0,34 \\
Mogi das Cruzes & 6 & 0,34 \\
Juquitiba & 4 & 0,23 \\
Franco da Rocha & 2 & 0,11 \\
Dladema & 1 & 0,06 \\
Total & 1.753 & 100,00 \\
\hline
\end{tabular}

Fonte: Questionärio Domiclilar 1973/74 
Os números deste quadro informam a supremacia da cidade de são Paulo como local de procedêncla. Mais da metade dos emigrantes desta região da Grande São Paulovieram da capital paulista.

Osasco, como cldade industrial e polo sub-regional, apresenta problemas que dificultam a flxação no local. Ass $1 \mathrm{~m}$, a proximidade, allada às facilidades oferecidas pe los melos de circulação, torna esse municipio um centro de emigração (vide Fig. XXVIII).

3.3. Motivos para a fixação em Jandira.

Para detectar as causas do crescimento populacional de Jandira elaborou-se e aplicou-se um questionário. Inquir ram-se setecentas e oitenta e sete famillas,atingindo-se un total de 31,81 ì das residências.

Da amostragem foi possivel extrair as principais causas que determinaram a escolha dessa cidade como local de residência, pela atual população.

QUADRO XVII

Motivos para fixação em Jandira

\begin{tabular}{|l|r|r|}
\hline \multicolumn{1}{|c|}{ Motivo } & Familias & \\
\hline gostou da cidade & 159 & 20,20 \\
lugar tranquilo e sem poluição & 140 & 17,78 \\
facilidade para obterção de emprego & 97 & 12,32 \\
facilidade para aquisĩ̧̧̄o de casa prōpria & 89. & 11,30 \\
facilidade para aquisição de terreno & 84 & 10,67 \\
parentes na cidade & 62 & 7,87 \\
proximidade do local de trabalho & 40 & 5,08 \\
proximidade de são Paulo & 26 & 3,30 \\
aluguel mais barato & 7 & 0,88 \\
outros & 83 & 10,54 \\
totais & 787 & 100,00 \\
\hline
\end{tabular}

Fonte: Questionārio Domiciliar 1976 


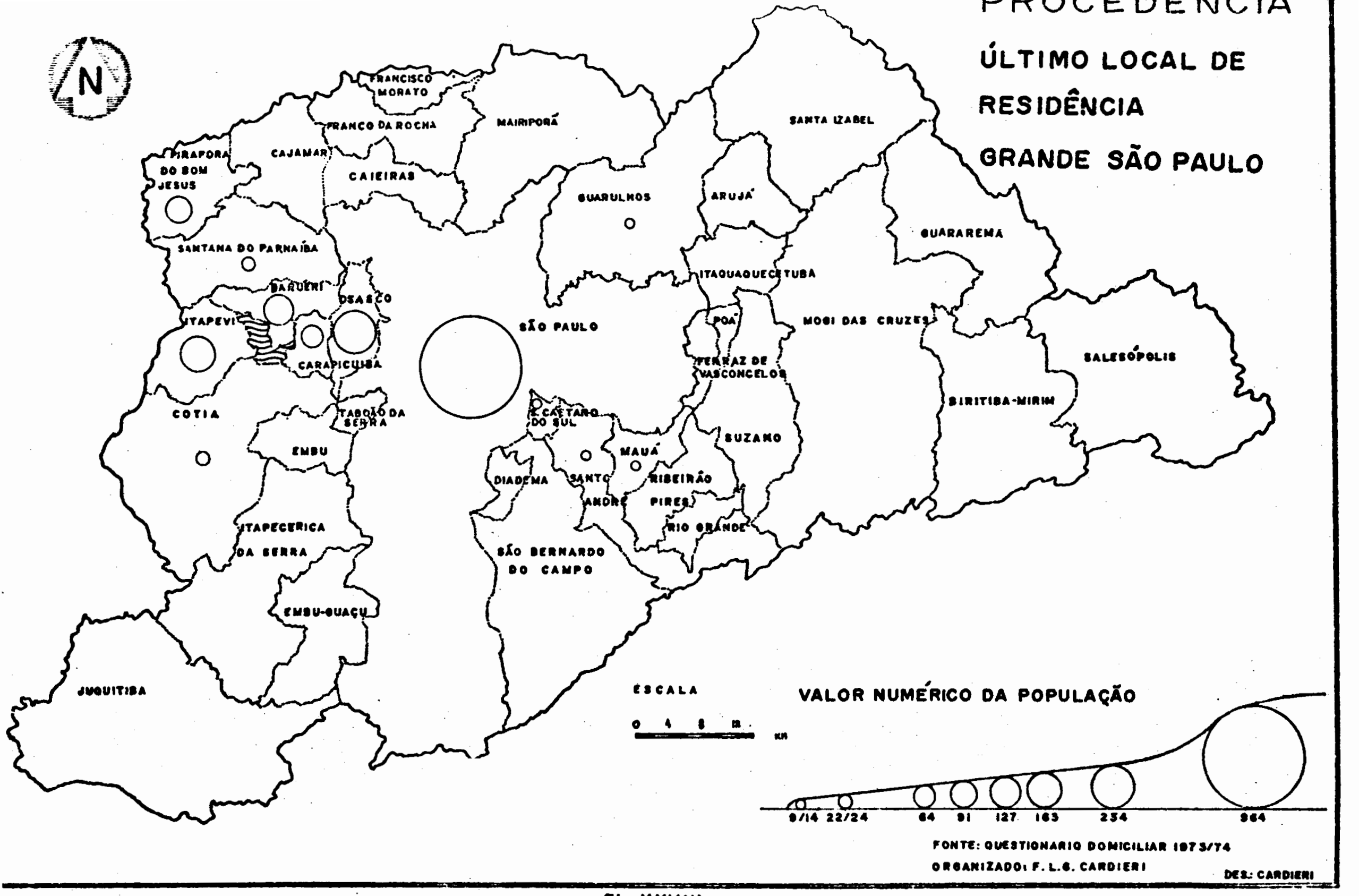


Apesar de 20,208 afirmarem que escolperam Jandira porque gostaram da cidade e 17,788 por ser um lugar tran quilo e sem poluição, è provãvel que os entrevistados que assim responderam ao quesito, tenham tido outros motivos, mais objetivos, além dos revelados, para se fixarem no lo cal. Talvez essa opção tenha sido motivada pelos preços acessiveis de terrenos ali encontrados além da relativa facilidade de transporte oferecida pela FEPASA.

Parece haver mais realismo nos motivos abaixo ar rolados, como, por exemplo, a facilidade para obtenção de emprego. Mesmo assim, a verdade é que a atração exercida pelo Frigorifico Jandira, a malor indústria do municipio na época e pela Pedreira Jandira não chegam a correspon der às expectativas, no que tange à oferta de empregos , que fica multo aquém da procura, atendendo apenas a uma parcela restrita da população.

Já fol dito que um fator de peso na decisão dos migrantes fol a possibilidade de aquisição de moradia (terreno ou casa já construía). Esta concretização fi ca duplamente comprovada: em primeiro lugar, pelas res postas dadas pelos entrevistados afirmando o desejo de adquirirem imóvel $(11,308$ desejavam obter casa própria e 10,678 comprar terreno); em seguida, o fato já apontado do grande número de proprietários $(76,768$ em 1974).

Parentes morando no local, anteriormente, também motivaram 7,878 das familias pesquisadas a escolherem 0 municipio de Jandira.

A proximldade com o local de trabalho fol o moti vo alegado por 5,088 dos entrevistados, mas tal afirmação pode referir-se não apenas a trabalho local, como também 
à proximidade de outros centros econômicos, facilmente $1 \underline{1}$ gados a Jandira pela ferrovia citada.vários outros mot 1 vos foran apontados pelos entrevistados, cada um deles representando, porém, multo pouco dentro do contexto.

Pelos dados dos Censos de 1950, 1960 e 1970 à razoável concluir que o crescimento demográfico da cidade começou a acelerar-se por volta da década 60/70. Veja-se, a propósito, a Fig. XXIX e também o quadro XVIII, cujos. dados obtidos através de enquete corroboram as informa çōes censitárias.

\section{QUADRO XVIII}

Fluxo Migratório de Familias 1916 - 1975

\begin{tabular}{|c|c|c|c|}
\hline & Década & $\begin{array}{l}\text { Quant. } \\
\text { Familias }\end{array}$ & 8 \\
\hline 1966 & a 1975 & 492 & 62,52 \\
\hline 1956 & a 1965 & 237 & 30,11 \\
\hline 1946 & a $\quad 1955$ & 47 & 5,97 \\
\hline 1936 & a $\quad 1945$ & 9 & 1,14 \\
\hline 1926 & a 1935 & 1 & 0,13 \\
\hline 1916 & a $\quad 1925$ & 1 & 0,13 \\
\hline \multicolumn{2}{|l|}{ totais } & 787 & 100,00 \\
\hline
\end{tabular}

Fonte: Questionārio Domiciliar 1976

Fo1 nos últimos quinze anos que o fluxo migratō rio para Jandira se intensificou sendo marcante sua curva de ganhos populacionais. No periodo precedente,o incremen to populacional fol um tanto lento,permanecendo, até mesmo, Inalterado em alguns anos. De 1916, ano que fornece os pr 1 melros dados comprováveis, a 1955, apenas cinqtlenta e o1to fa 


\section{JANDIRA: FLUXO MIGRATO'RIO DE FAMILIAS $1816-1976$}

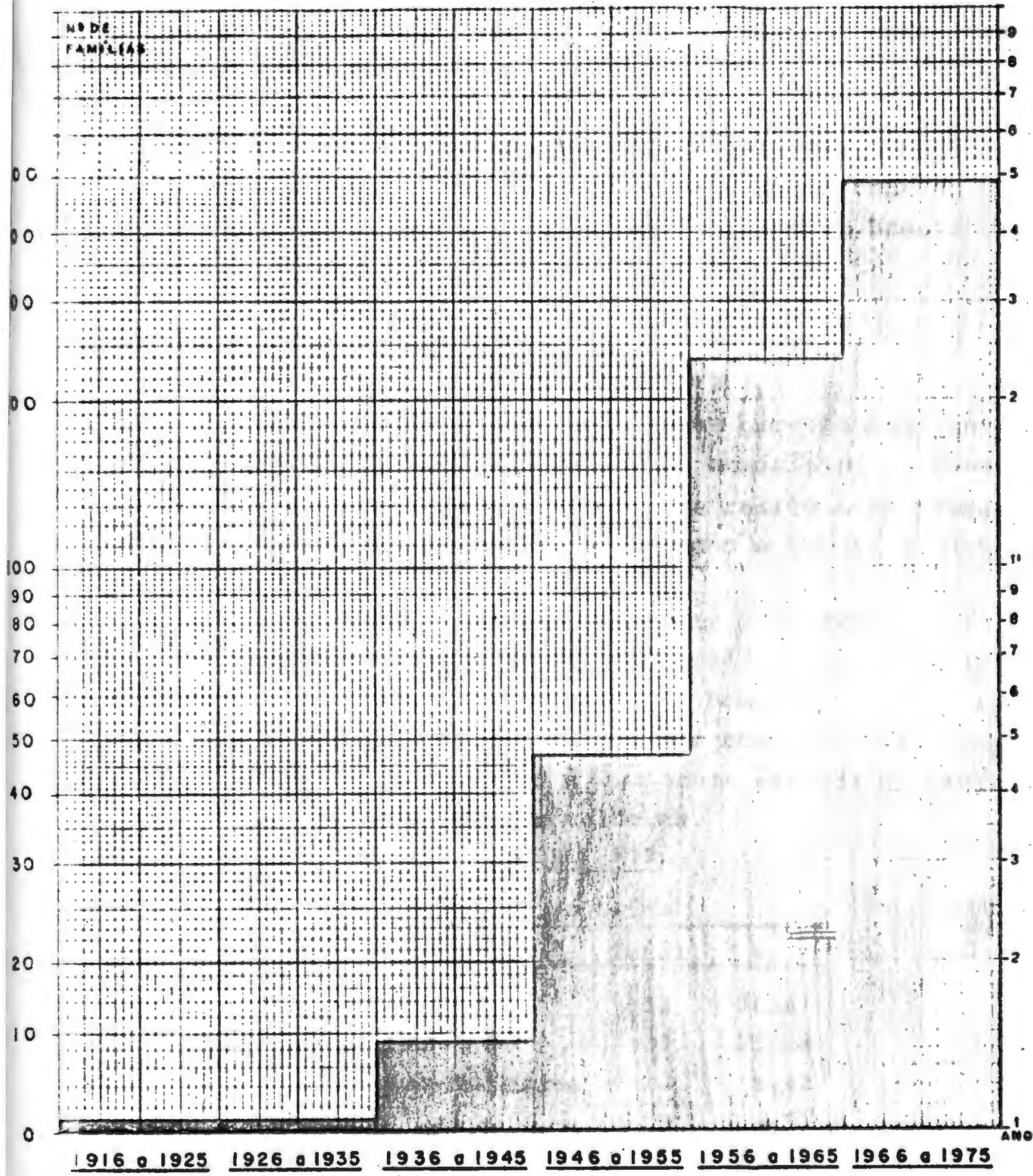

fonte: oUEstionÁRIO DomICJIAR-IOTE

AMOSTRA-POTFAMRLA

OREANI2ADO: F.L. O.CAMOICAI

DES.CARDUER! 
millas pesquisadas Imigraram para Jandira, perfazendo 7,378. A especulação 1moblilär1a, assim como o crescimen to da metrōpole, deram sua contribulção para o crescimen to nos ültimos anos.

o crescimento vegetativo é superado, em multo,como já fol visto, pelo fluxo migratór1o, que traz consigo , aliás, Individuos das mals variadas paragens do Brasil e até mesmo do exterior.

\section{-4. Emigração}

Os dados concernentes à emigração foram conseguldos junto a parentes das pessoas que sairam do municipio. Desta forma, nas setecentas e setenta e nove residénclas pesqu1 sadas constatou-se a existência de cento e trinta e o1to migrantes.

significativo fol o deslocamento resultante da fal ta de trabalho na cidade (vide Quadro $\mathrm{XIX}$ ): 38,418 gairam em busca de emprego. Este percentual pode inclusive ex plicar os números da diferenciação por sexo: a cifra mas culina $(55,078)$ fol superior à feminina: setenta e seis homens para sessenta e duas mulheres.

\section{QUADRO XIX}

Motivo da SaIda

\begin{tabular}{|l|r|r|}
\hline \multicolumn{1}{|c|}{ Motivo } & Total & \multicolumn{1}{c|}{8} \\
\hline trabalho & 53 & 38,41 \\
casamento & 32 & 23,19 \\
problemas familiares & 13 & 9,42 \\
estudo & 9 & 6,52 \\
outros & 26 & 18,84 \\
sem resposta & 5 & 3,62 \\
totals & 138 & 100,00 \\
\hline
\end{tabular}

Fonte: Questionārio Domicillar 1973/74 
Um outro fator relacionado ao primeiro é a ldade (Quadro $\mathrm{XX}$ ) , pois 72,468 encontravam-se entre quinze e sessenta e quatro anos, faixa etárla da população considẹ rada ativa; temos ainda que 25,368 dos que saíram tinham de quinze a dezenove anos, isto $\hat{e}$, estavam justamente nu ma fase de procura de emprego.

\section{QUADRO $\mathbf{X X}$}

Idade e Sexo dos Emigrantes

\begin{tabular}{|c|r|r|r|r|r|r|}
\hline Idade & Total & \multicolumn{1}{|c|}{8} & Masc. & 8 & Fem. & 8 \\
\hline $0-4$ & 21 & 15,21 & 10 & 7,24 & 11 & 7,97 \\
$5-9$ & 6 & 4,34 & 3 & 2,17 & 3 & 2,17 \\
$10-14$ & 9 & 6,52 & 3 & 2,17 & 6 & 4,35 \\
$15-19$ & 35 & 25,36 & 17 & 12,32 & 18 & 13,04 \\
$20-24$ & 33 & 23,91 & 18 & 13,04 & 15 & 10,87 \\
$25-29$ & 12 & 8,69 & 9 & 6,52 & 3 & 2,17 \\
$30-34$ & 2 & 1,46 & 1 & 0,73 & 1 & 0,73 \\
$35-39$ & 5 & 3,62 & 4 & 2,90 & 1 & 0,72 \\
$40-44$ & 3 & 2,17 & 1 & 0,72 & 2 & 1,46 \\
$45-49$ & 4 & 2,90 & 3 & 2,17 & 1 & 0,73 \\
$50-54$ & 3 & 2,17 & 3 & 2,17 & - & - \\
$55-59$ & 2 & 1,46 & 2 & 1,46 & - & - \\
$60-64$ & 1 & 0,73 & - & - & 1 & 0,73 \\
$65-69$ & - & & - & - & - & - \\
70 e & 2 & 1,46 & 2 & 1,46 & - & - \\
total & 138 & 100,00 & 76 & 55,07 & 62 & 44,93 \\
\hline
\end{tabular}

Fonte: Questionärio Domiciliar 1973/74

As crlanças (zero a catorze anos) representam 26,098 dos emigrantes e os velhos, apenas 1,458, represen tados por dols homens com mals de setenta anos. 
- eaasamento figura entre ós motivos pára o déslocą pento da populaçã̃o: 23,198 dós jóvens ao eảsarem=se thixam

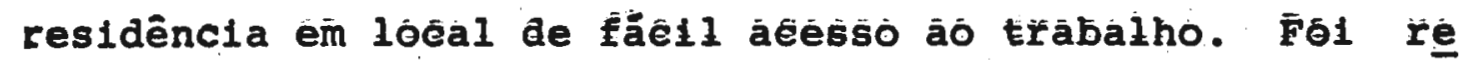

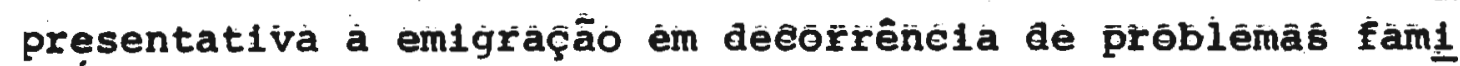
liares: 10,888. Os denàis, como, estudar, gánhhar mélhor,

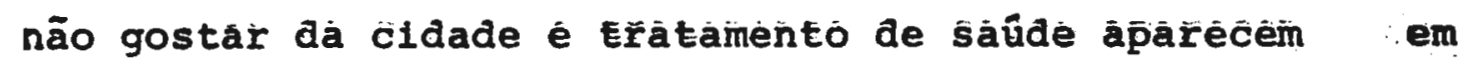
proporção mult to pequena.

o periłodo mais signifieátivo para a emigraçãó com 42,778 dos casos fol $1972 / 73$ (observe-se o Quadro XXXI) e a Fig. XXX.

\begin{tabular}{|c|c|c|}
\hline Ano & Total & 8 \\
\hline 1952 & 1 & 0,72 \\
\hline 1953 & 1 & 0,72 \\
\hline 1957 & $i$ & 0,72 \\
\hline 1959 & $i$ & 0,72 \\
\hline 1961 & 4 & 2,90 \\
\hline 1962 & 1 & 0,72 \\
\hline 1963 & 2 & 1,46 \\
\hline 1964 & 7 & 5,07 \\
\hline 1965 & 4 & 2,90 \\
\hline 1966 & 5 & 3,62 \\
\hline 1967 & 4 & 2,90 \\
\hline 1968 & 3 & 2,17 \\
\hline 1969 & 6 & 4.35 \\
\hline 1970 & 14 & 10,15 \\
\hline 1971 & 7 & 5,07 \\
\hline 1972 & 30 & 21,75 \\
\hline 1973 & 29 & 21,02 \\
\hline $\begin{array}{r}1974 \\
s / x \\
\text { total } \\
\end{array}$ & $\begin{array}{r}9 \\
9 \\
+138 \\
\end{array}$ & $\begin{array}{r}6,52 \\
6,52 \\
100,00 \\
\end{array}$ \\
\hline
\end{tabular}

Fónte: Questionărio Domfelilar $1973 / 74$ 
JANDIRA

EMIORAGÃO 1056/78

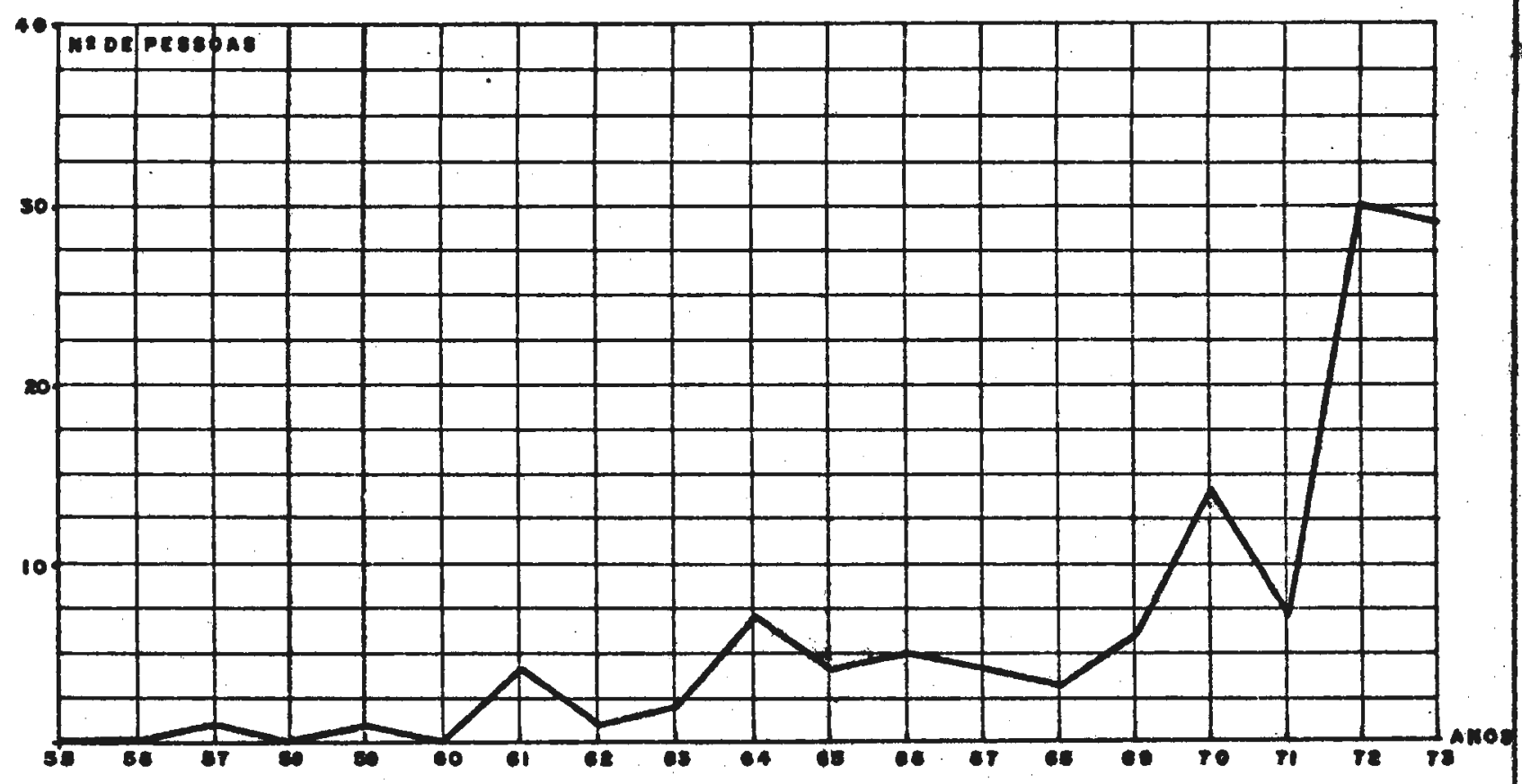

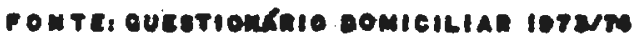

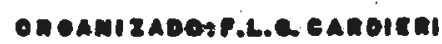


A emigração se fez em maior escala para diversas regiões do Estado de São Paulo, totalizando 78,998 dos emigrantes. Dos cento e nove que optaram pelo Estado de são Paulo, oitenta e oito, correspondentes a 63,768 do total, deslocaram-se para a prōpria Região Administrativa da Grande são Paulo, na qual a cidade de são Paulo concen trou 43,188 e osasco 26,138 dos jandirenses. Como é natú ral, as cidades procuradas foram justamente as que tinham condições de absorver maior quantidade de mão-de-obra,pos suindo escolas de todos os niveis, e outras vantagens.

Para os demais Estados o contingente da emigração fol pequeno, de modo geral, variando de 0,728 a $3,63 \%$. Houve até o caso de um chefe de familia que está trabá lhando temporiamente na construção da Rodovia Transamazônica.

Apenas 26,818, correspondendo a trinta e sete das pessoas que sairam, pretendem voltar; os demais, 72,47\%, partiram definitivamente. Houve um caso isolado de omis são de resposta, constituindo 0,728 .

Le um total de três mil e novecentos e cinquenta e oito pessoas inquiridas, nove pretendem sair de Jandira brevemente. Os motivos alegados foram, proporionalmente os mesmos dos que já saîram para outras cidades.

\subsection{Composição por Sexo, Idade e Escolaridade}

Os dados censitārios mostram que na composição lirbana bra sileira predomina o sexo feminino, mas em Jandira ocorre - inverso, apesar da disparidade entre os sexos não ser relevante. Em 1974 existiam hum mil e novecentos e noven ta e um homens para hum mil e novecentas e ses senta e sete mulheres, respectivamente 50,318 e 49,698 . 
Cónsiderando apenas os nascidos no município, a po pulação masculina ainda eontinua mais numerosa: trezentos e cinqlienta e seis homeñs $(50,728)$ para trezentas e qua renta e seis mutheres $(49,288)$.

o Quadro XXII, bem como a pirâmide dé Idade, Figu ra XXXI, mostram o predominio da população jovem no muni cIp10.

$$
\text { QUADRO - XXII }
$$

População por faixa etária

\begin{tabular}{|c|c|c|c|c|c|c|c|c|c|c|c|c|}
\hline \multirow{3}{*}{ LDADE } & \multicolumn{6}{|c|}{ POPULAÇTO TOTAL } & \multicolumn{6}{|c|}{ NATURAIS DE JANDIRA } \\
\hline & \multicolumn{2}{|c|}{ Total } & \multicolumn{2}{|c|}{ Pasculino } & \multicolumn{2}{|c|}{ Feninino } & \multicolumn{2}{|c|}{ Total } & \multicolumn{2}{|c|}{ Masculino } & \multicolumn{2}{|c|}{ Feninine } \\
\hline & NP & 8 & N8 & 8 & NQ & 8 & 198 & 8 & NC & 8 & $\mathrm{NO}$ & 8 \\
\hline 4 & 523 & 13,21 & 257 & 6,49 & 266 & 6.72 & 339 & 48,29 & 158 & 22,51 & 181 & 25,78 \\
\hline 9 & 599 & 15,13 & 304 & 7,68 & 295 & 7,45 & 196 & 27,92 & 90 & 13,96 & 98 & 13,96 \\
\hline 14 & 510 & 12,89 & 269 & 6.80 & 241 & 6,09 & 102 & 14,53 & 60 & 3,55 & 42 & 5,98 \\
\hline 19 & 424 & 10,71 & 202 . & 5,10 & 222 & 5,61 & $\cdot 34$ & 4,85 & 19 & 2,71 & 15 & 2,14 \\
\hline 24 & 405 & 10,23 & 205 & 5,18 & 200 & 5,05 & 17 & 2,43 & 12 & 1,71 & 5 & 0,72 \\
\hline 29 & 328 & 8,28 & 164 & 4,14 & 164 & 4,14 & 7 & 1,00 & 5 & 0,72 & 2 & 0,28 \\
\hline 34 & 250 & 6,57 & 132 & 3,34 & 128 & 3,23 & 2 & 0.28 & 1 & 0,14 & 1 & 0,14 \\
\hline 39 & 220 & 5,56 & 106 & 2,68 & 114 & $2, \varepsilon 8$ & 1 & 0.14 & - & - & 1 & 0,14 \\
\hline 44 & 124 & 4,90 & 100 & 2,53 & 94 & 2,37 & 1 & 0,14 & - & - & 1 & 0,14 \\
\hline 49 & 172 & 4,35 & 84 & 2,12 & 88 & 2,23 & 1 & 0,14 & 1 & 0,14 & - & - \\
\hline 54 & 116 & 2,93 & 60 & 1,52 & 56 & 2,41 & 1 & 0,14 & 1 & 0,14 & - & - \\
\hline 59 & 92 & 2,33 & 45 & 1,14 & 47 & 1,19 & - & - & - & - & - & - \\
\hline 64 & 55 & 1,39 & 33 & 0,83 & 22 & 0,56 & 1 & 0,14 & 1 & 0,14 & - & - \\
\hline 69 & 26 & 0,66 & 13 & 0,33 & 13 & 0,33 & - & - & - & - & - & - \\
\hline $\operatorname{nos}$ e + & 34 & 0.86 & 17 & 0.43 & 17 & 0,43 & - & - & - & - & - & - \\
\hline 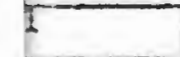 & 3558 & 100,00 & 1991 & 30,31 & 1967 & 49.65 & 702 & 100,00 & 356 & 50.72 & 346 & 49,28 \\
\hline
\end{tabular}

Fonte: Questionário Domicillar 1973/74 


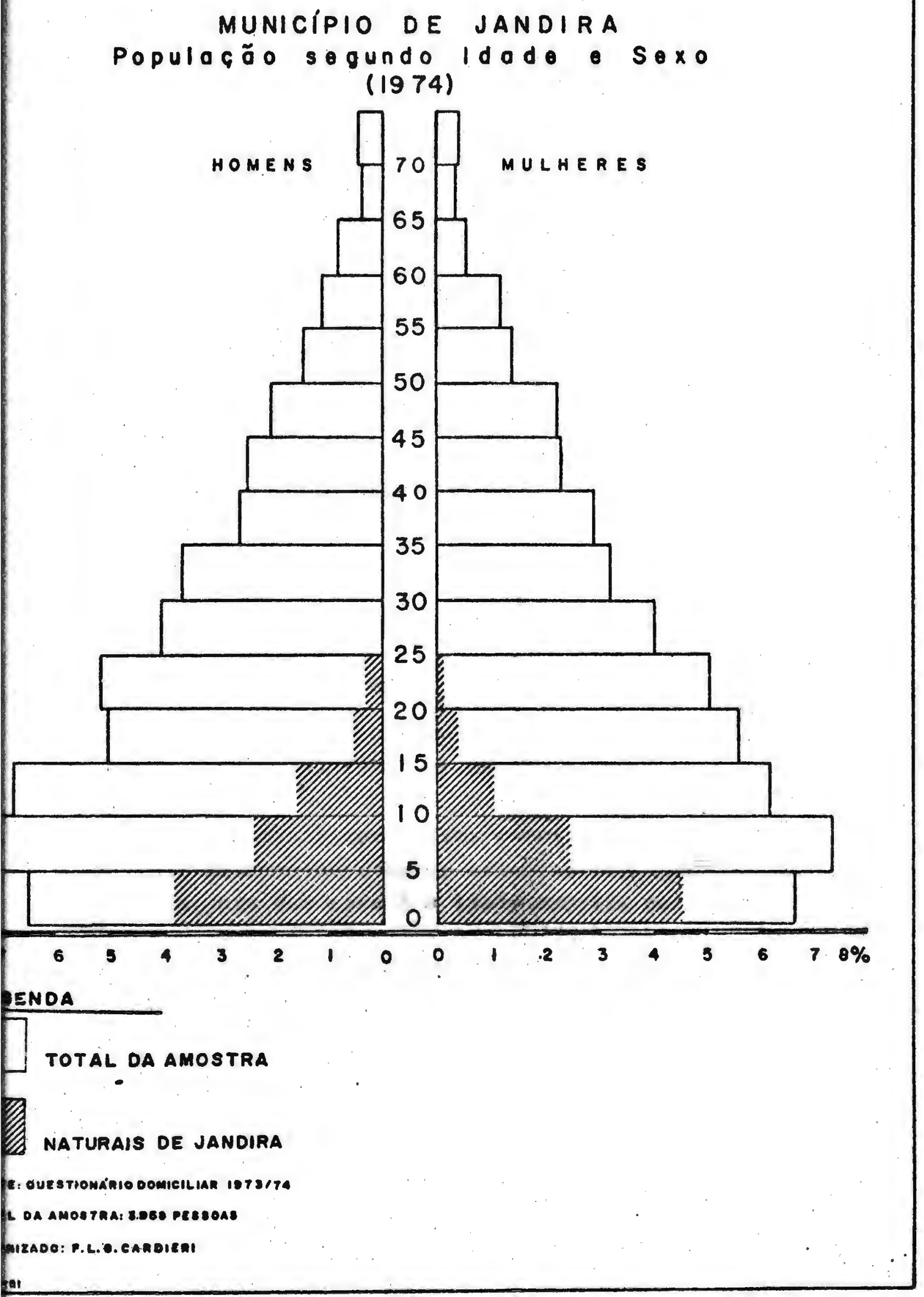


Marla Luiza Marcilio escreve que " O fenômeno da po pulação jovem é uma característıca das populaçōes do tipo antigo, antes de começar sua transição demogrāfica, como também dos países em via de desenvolvimento" (38). E o ca so do Brasil.

Conforme a Consolidação das Leis do Trabalho vigen te no pais, os jovens tornam-se economicamente ativos a partir dos quatorze anos e a aposentadoria por velhice é concedida aos sessenta e cinco anos. Desta forma, agrupouse a população considerando-se crianças, as pessoas de ze ro a treze anos; ativos, de quatorze a sessenta e quatro anos e velhos, a partir de sessenta e cinco anos.

Muito significativo sem dúvida, é o número de crian ças, que const1tuem 40,058 do total da amostragem.Contudo, a população potencialmente ativa è a de maior expressão , com 58,468. Neste grupo, è oportuno salientar a classe de quinze a vinte e nove anos (39).

o último dos três grlipos, dos inativos pela 1dade, è quase insignificante, representando apenas 1,498. De res to, isto espelha a realidade do Brasil, ou seja quanto mals avançada a falxa etária, menor é o número de indivi duos que a compōem, fato que as estatisticas comprovam.

Para definir com maior precisão o grau de escolari dade, não se consideraram as crianças com idade infertor a sete anos, eis que esta é a ldade exigida para a matricula

(38) Maria Luiza MARCIIIo - "A Cidade de São Paulo - Povoạ mento e População - 1750-1850" - USP - 1974 - p.112.

(39) Chabot, no seu "Traité de Geographie Urbaine", p.355 diz "Entre os migrantes do tipo econômico, mais de 508 se deslocam antes da ldade de 30 anos. São, portanto, indiví duos jovens que a cidade recebe no momento em que estāo prestes a constituir familias". 
nos estabelecimentos oficiais. Subtraiu-se, pois, do núme ro inicial da amostragem oitocentas e vinte e duas crian ças, cifra que corresponde a 20,778 da população.

- Quadro XXIII mostra a situação dos habitantes quan to à escolaridade.

$$
\text { QUADRO - XXIII }
$$

Jandira - Grau de Escolaridade da População

\begin{tabular}{|l|l|r|r|}
\hline \multicolumn{2}{|c|}{ ESCOLARIDEDE } & NQ & \multicolumn{1}{c|}{} \\
\hline Analfabeto & Analfabeto & 426 & 13,58 \\
& assina & 65 & 2,07 \\
\hline Năo frequentou & Lế & 3 & 0,09 \\
escola & Lề e escreve & 125 & 3,99 \\
\hline Pré-escolar & Pré-primário & 14 & 0,45 \\
\hline 18 grau & Prim.incompleto & 1.156 & 36,86 \\
& Prim. completo & 735 & 23,44 \\
& Gin. incompleto & 434 & 13,84 \\
& Gin.Completo & 64 & 2,04 \\
\hline 28 grau & Coleg.incompleto & 56 & 1,79 \\
& Coleg.completo & 23 & 0,73 \\
\hline Superior & Curso incompleto & 12 & 0,38 \\
& Curso completo & 8 & 0,26 \\
\hline Outros & Cursinho & 1 & 0,03 \\
& Profissionais & 14 & 0,45 \\
\hline
\end{tabular}

Fonte: Questionārio Domiciliar 1973/74

o grupo mais numeroso é o atinente ao : primeiro grau, englobando tanto os indivíduos que cursaram o primá rio como o gināsıo, pols o sistema vigente, na ocasião da pesquisa, alnda era o constituído de : primei ro ciclo=primārio (quatro anos), gināsio (quatro anos) e segundo ciclo, colegial (très anos) e superior. Neste gru po, por conseguinte, podem ser destacados os individuos que não concluiram a quarta série, estancio nele incluídos também, os que ainda cursavam o primário e os,que o têm completo. 
Ao que tudo indica, não se trata de fato isolado mas comum e associado à necessldade de começar a trabalhar cedo e às dificuldades para estudar na cidade, pois até 1974 o curso colegial tinha que ser feito fora. Assim talvez, a falta de perspectiva de continuidade tenha nega do ao estudante motivação ou condições para continuar os estudos. Ao lado disso, a condição sōcio-econômica da po pulação não possibilita a manutenção de um filho cursando gināsio, visto como o número e a diversidade das disciplí nas exigem maiores gastos com material escolar, importando isto em braços parados e menos ganhos para a familia.

Com todas essas dificuldades, não poderia deixar de ser Infimo o número de pessoas que chegaram a concluir $\circ$ curso superior.

Mesmo os cursos profissionalizantes, que propicia riam beneficios mais rãpidos, ainda não são muito procura dos pelos habitantes do município,o que se deve a dificulda des de locomoção até à escola, ensino pago e incompatibili dade de horārios (trabalho-locomoção-aulas).

3.6. Estrutura Profissional da População Ativa

Constam da amostragem duzentos e três tipos de ocu paçōes. Para facilitar a anälise, tentou-se agrupá-las , utilizando a classificação adotada pela FIBGE (40), como no quadro a seguir:

(40) Censo Demográfico - FIBGE 
Grupos de Ocupação e Salárlo (como proporção com o salárlo mínimol por sexo

\begin{tabular}{|c|c|c|c|c|c|c|c|c|c|c|c|}
\hline \multirow{3}{*}{ DCUPAÇÃO } & \multirow{2}{*}{\multicolumn{2}{|c|}{$\frac{\text { Anterior }}{\text { Total }}$}} & \multirow{2}{*}{\multicolumn{9}{|c|}{$a+u_{\text {Homens }}$ (*) }} \\
\hline & & & & & & & & & & Mulher & \\
\hline & $T$ & $\frac{8}{8}$ & $T$ & 8 & SM & $T$ & $8-$ & SM & $\mathrm{T}$ & 8 & $S M$ \\
\hline istrativas & 66 & 5,44 & 87 & 5,67 & $1-2$ & 63 & 5,64 & $1-2$ & 24 & 5,78 & $1-2$ \\
\hline $\begin{array}{l}\text { zas, clentifi } \\
\text { artisticas }\end{array}$ & 16 & 1,32 & 34 & 2,22 & $1-3$ & 19 & 1,70 & $1-3$ & 15 & 3,61 & $1-2$ \\
\hline $\begin{array}{l}\text { Ultura, extrativ. } \\
1 \text { e vegetal }\end{array}$ & 160 & 13,19 & 15 & 0,98 & $0,5-1$ & 15 & 1,34 & $0.5-1$ & - & - & - \\
\hline extrat.mineral & 1 & 0,08 & - & - & - & - & - & - & - & - & - \\
\hline $\begin{array}{l}\text { e transf. e cons } \\
\text { o civil }\end{array}$ & 445 & 36,89 & 628 & 40,97 & $1-3$ & 495 & 44,27 & $1-3$ & 133 & $32-05$ & $1-2$ \\
\hline $\begin{array}{l}\text { cio e ativ.auxi- } \\
\text { s }\end{array}$ & 88 & 7,25 & 150 & 9.78 & $1-2$ & 114 & 10,20 & $1-2$ & 36 & 8,68 & $1-2$ \\
\hline porte e comun. & 53 & 4,37 & 76 & 4,96 & $1-3$ & 74 & 6,62 & $1-3$ & 2 & 0,48 & $1-3$ \\
\hline . de servlços & 188 & 15,50 & 187 & 12,20 & $0.5-2$ & 43 & 3,85 & $1-2$ & 144 & 34,70 & $0,5-1$ \\
\hline $\begin{array}{l}\text { s ocupaçõas mal } \\
\text { idas ou não de } \\
\text { das. }\end{array}$ & 196 & 16,16 & 266 & 17,35 & $1-2$ & 225 & 20,12 & $1-2$ & 41 & 9,88 & $1-2$ \\
\hline $\operatorname{ros}(* *)$ & - & - & 90 & 5,87 & $0,5-1$ & 70 & 6,26 & $0,5-2$ & 20 & 4,82 & $0-1$ \\
\hline & 1.213 & 100,00 & 1.533 & 100,00 & $I-2$ & 1.118 & 100,00 & $1-2$ & 415 & 100,00 & $I-2$ \\
\hline
\end{tabular}

inte: Questionärıo Domiciliar 1974

1974

**) consideram-se inativos: inválidos., aposentados e afastados

Bem nitido, no quadro, o predomínio do sexo masculi no na força de trabalho: 72,938 do total. A indústria ab sorve 40,978 da população ativa e as mulheres se ocupam principalmente da indústria do vestuário, destacando-se a costureira, profissão de 30,078 (quarenta pessoas) das in dustriärias.

Responderam ainda,sobre as demais, a cerzldeira, a arrumadeira e a overloquista. Nos outros setores de indús tria, a presença da mulher é quase insignificante.

Os homens exercem diversas atividades nos diferen tes ramos da indústria, sobretudo na construção civil que agrupa 31,928 dos ocupados na indústria. 
- Grupo III, que engloba as ocupaçōes da agrope cuāria eda produção extrativa vegetal e animal, represen ta apenas, 0,98\% do pessoal ocupado. Isto se explica pe la inexpressividade do setor primário na região, o que po de ser observado no Quadro XXV

$$
\text { Quadro - XXV }
$$

Sub-Região Noroeste - Atividades Agropecuãrıas - 1970

\begin{tabular}{|c|c|c|c|c|c|c|c|c|c|c|c|}
\hline \multirow{2}{*}{ MUNICIPIOS } & \multicolumn{2}{|c|}{ Estabelecimento } & \multicolumn{3}{|c|}{ Area } & \multicolumn{3}{|c|}{ pes. orupado } & \multicolumn{3}{|c|}{ valor da pzoducäe } \\
\hline & ne & (1) (2) & ha & (1) & (2) & no & (1) & (2) & crst.000 & (1) : & $12 i$ \\
\hline & 7 & $0,30,1$ & 1.491 & 2,6 & 0,6 & 20 & 0,3 & 0,1 & 406 & 1,2 & 0,1 \\
\hline & 222 & $11,92,3$ & 4.648 & 8,4 & 2,0 & 656 & 9,5 & 1,6 & 2.358 & 7,1 & 0.7 \\
\hline Carapiculba & 21 & 0,60, & 54 & 0,1 & - & 43 & 0,6 & 0,1 & 110 & 0,3 & - \\
\hline Itapev1 & 13 & 0,70, & 241 & 0,4 & 0,1 & 54 & 0,8 & 0,1 & 334 & 1.4 & 0,1 \\
\hline Jandl $r a$ & 5 & $0,30,1$ & 11 & - & - & 27 & 0.4 & 0,1 & 31 & 0,1 & - \\
\hline Osasco & 14 & 0.80, & 155 & 0,3 & 0,2 & 55 & 0,3 & 0,1 & 477 & 1.4 & 0.1 \\
\hline Pirapora do Bom Jesus & 106 & 5.71 .1 & 4.346 & 7,9 & 1.3 & 32.4 & 4.7 & 1,0 & 1.219 & 3,7 & 0,4 \\
\hline Santana de Parnalba & 187 & $10,02,0$ & 11.065 & 19,9 & 4,6 & 614 & 8,9 & 1,5 & 2.437 & 7,4 & 0,7 \\
\hline 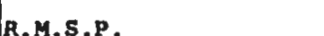 & 9.636 & $-100,0$ & 237.775 & - & 800,0 & 40.404 & - & 200,0 & 339.119 & - & 100,0 \\
\hline
\end{tabular}

(1) Porcentagem sobre o total da Sub-Região

(2) Porcentagem sobre o total da Região Metropolitana

Fonte: FIBGE - Censo Agropecuár1o - 1970

Exame de fotografias aéreas e constatação no campo, revelaram que em 1974 apenas duas propriedades agrícolas eram exploradas; uma dedicando-se ao cultivo de flores e a outra à horticultura, não se encontrando cultura perene no município, a não ser pomar em fundo de quintal. Esse dado contraria os dados do Instituto de Economia Ajrícola (Previsão Subjetiva, junho/75), os quais apontam 59 ha de produtos animais e 14 ha de produtos perenes para a ãrea em estudo. 
Não fol encontrado, na anostra, pessoal ocupado na indústria extrativa mineral. Entretanto, há uma pedreira no município e 71,428 dos seus funcionārios são de Jandi ra. Ressalve-se, porēm, que essa percentagem corresponde a apenas quinze pessoas.

A prestação de serviços é a única atividade que o ferece um número de mulheres superior ao dos homens, supe rłoridade explicada pelo nümero de empregadas domésticas - 56,948 do total. Inquiriram-se oltenta e duas delas e as respostas asseguram que 20,738 ganham menos de meio ( $0,5)$ salário mínimo ; 57,328 ganhan de meio a um salá rio mínimo $18,29 \%$ de um a dois $(1-2)$ salários mí nimos; 2,448 de dols a três $(2-3)$ e apenas 1,228 (uma em pregada) tem salário superior a três salários mínimos , mas inferior a quatro. E conveniente ressaltar, no entre tanto, que hoje a realidade salarial é bem cutra.

Em "São Paulo 1975 - Crescimento e Pobreza" (41), o autor comenta que "Com exceção do emprego doméstico , tradicionalmente uma atividade feminina, nas ocupações de baixa qualificação - onde a escolarıdade não é requis 1 to importante e o salário está próximo ao mínimo, sendo reduzidas as possibilidades de se pagar menos à mulher - prevalece a preferência pela mão de obra masculina". o muntcipio de Jandira não foge à regra, de vez que nas 은 cupações de prestação de serviços e na indústria do ves tuārio a mulher é solicitada. Fora daí as atividades pró fissionais quase inexistem para ela. Apenas quinze $(3,61 q)$ trabalhadoras ganham mals que três salários mínimos e des sas, apenas três ganham mais que oito.

Por outra parte, duzentos e quarenta e sete $(22,098)$

(41) Candido P.F.Camargo e outros - São Paulo-1975 - Cres cimento e Pobreza - S.P., Edições Loyola,CEBRAP,1976 p.9व 
dos profissionais do sexo masculino possuem salário su perior a três salários minimos; destes, 78,13\% ganham de três a oito salārios mínimos.

Enquanto 63,168 dos homens que se dedicam às ocupa çōes tēcnicas, cientificas e artísticas têm salārios su periores a dols salärios minimos, 46,668 das mulheres que desempenham essas mesmas funçōes recebem de um a dois. Percebe-se claramente a discriminação contra o trabalho feminino.

Os Quadros XXVI e XXIX, comparados, evidenciam que que a mobilidade da mão-de-obra deve ser de uma firma pá ra outra, geralmente no mesmo bairro, pois não se regis tra muita diferença entre o local de trabalho anterior e o atual.

$$
\text { QUADRO - XXVI }
$$

Local de Trabalho da População Ativa - 1974

\begin{tabular}{|l|r|r|}
\hline Cjdade & Total & \multicolumn{1}{|c|}{8} \\
\hline Sao Faulo & 865 & 59,94 \\
Jandira & 262 & 18,16 \\
Osasco & 150 & 10,40 \\
Barueri & 39 & 2,70 \\
Itapevi & 14 & 0,97 \\
Outros & 32 & 2,22 \\
n/especif. & 81 & 5,61 \\
Total & 1,443 & 100,00 \\
& & \\
& & \\
\hline
\end{tabular}

\begin{tabular}{|l|r|r|}
\hline Bairro & Total & \multicolumn{1}{|c|}{8} \\
\hline Lapa & 259 & 29,94 \\
Barra Funda & 86 & 9,94 \\
Bom Retixo & 57 & 6,59 \\
Sta.Efigẽnia & 51 & 5,90 \\
Pinheiros & 32 & 3,70 \\
Sé & 29 & 3,35 \\
Consolą̧ão & 28 & 3,24 \\
Butantã & 15 & 1,73 \\
Outros & 114 & 13,18 \\
n/especif. & 194 & 22,43 \\
Totai & 865 & 100,00 \\
\hline
\end{tabular}

Fonte: Questionārio Domiciliar 1973/74

- quadro acima não deixa dúvida quanto à dependên cia do municipio no que se refere a trabalho: apenas 18,168 dos jandirenses desempenham suas atividades na 
prōpria cidade. Somada à inexistência de infra-estru tura urbana, essa dependência faz con que a cidade seja classificada como "dormitōrio": 81,848 da população ati va desloca-se diáriamente para os locals de trabalho sendo São Paulo e Osasco os mercados de trabalho mais procurados para sanarem tal deficiência. Observe-se que o deslocamento se faz em função da ferrovia, uma vez que, em São Paulo, a Lapa e a Barra Funda possuem estações da Fepasa. Ademais, a estação Jūlio Prestes, localizada no bairro dos Campos Elísios, fica próxima do Bom Retiro e Santa Efigênja, bairros de concentração de indústrias e prestação de serviços. Ao descer do trem, o trabalha dor faz a pé o percurso até o local de trabalho, nesses casos para Osasco, o deslocamento também se faz geralmen te por ferrovia. Embora Pinheiros possua terminal de ô nibus, que o liga a Jandira, não constitui importante 10 cal de trabalho, jã que não é um bairro industrial. Além disso, não é conveniente à população trabalhadora abdi car dos preços mais baixos e da rapidez oferecida pela ferrovia.

Nada menos de $64,80 \%$ (vide Quadro XXVII) da popula ção ativa está no último emprego há menos de dois anos e os empregados com menos de um ano de firma constituem $39,64 \%$ do total, entre estes apenas 16,57\% (cento e cin quenta e cinco pessoas) estão no primeiro emprego. Tais cifras permitem afirmar que se trata de mão-de-obra flu tuante. A mobilidade de ocupação é ocasionada pelos bai xos salários (vide Quadro XXVII) e pelas condições de trabalho oferecidas pelos empregadores. Assim, o traba lhador muda de emprego, alnda que por salário um pouco mais alto, na expectativa de uma vida melhor. Há ainda a considerar a legislação do Fundo de Garantia por Tem po de serviço, causa principal da rotatividade da mão-de obra, que se observa, de resto, em todo o País. 
Tempo de Firma da Povulação At1va

\begin{tabular}{|c|c|c|}
\hline ano & $\begin{array}{l}\text { N8 de } \\
\text { Empregados }\end{array}$ & 8 \\
\hline-1 & 572 & 39,64 \\
\hline 1 a 2 & 363 & 25,16 \\
\hline 3 a 5 & 196 & 13,59 \\
\hline 6 a 10 & 125 & 8,65 \\
\hline+10 & 96 & 6,65 \\
\hline n/especif. & 91 & 6,31 \\
\hline Total & 1.443 & 100,00 \\
\hline
\end{tabular}

Fonte: Questionário Domicillar 1973/74

Entre os 1nativos, os aposentados são majoritários, representando 46,678 . Os afastados correspondem a 31,118 e os inválidos 22,228. Encontraram-se, neste grupo , vinte inválidos e, destes, dezessete sem rendimentos , inclusive dez mulheres.

o Quadro XXVIII mostra a posição no trabalho dos e lementos economicamente ativos de Jandira.

$$
\text { QUADRO - XXVIII }
$$

População Ativa-Situação na Firma

\begin{tabular}{|l|r|r|}
\hline S1tuação na Firma & Total & \multicolumn{1}{|c|}{8} \\
\hline Empregado & 1.331 & 92,24 \\
Patrão & 65 & 4,50 \\
Autônomo & 45 & 3,12 \\
Estag̃ã̃io & 1 & 0,07 \\
Patrão/Empr. & 1 & 0,07 \\
\hline
\end{tabular}

Fonte: Questionário Domiciliar 1973/74 
Encontraram-se seiscentas e quarenta e oito mulheres que se ocupam das atividades do lar, e setecentos e vin te estudantes. Assim, o nưmero de desocupados é maior entre os homens,já que as mulheres que não trabalham fo ra ocupan-se de afazeres domésticos.

Considerando a quantidade de imigrantes na popula ção do município, tomou-se como base o estado de origem para verificar o local de trabalho que precedeu o atual.

$$
\text { QUADRO - XXIX }
$$

Local de Trabalho Anterior - 1973/74

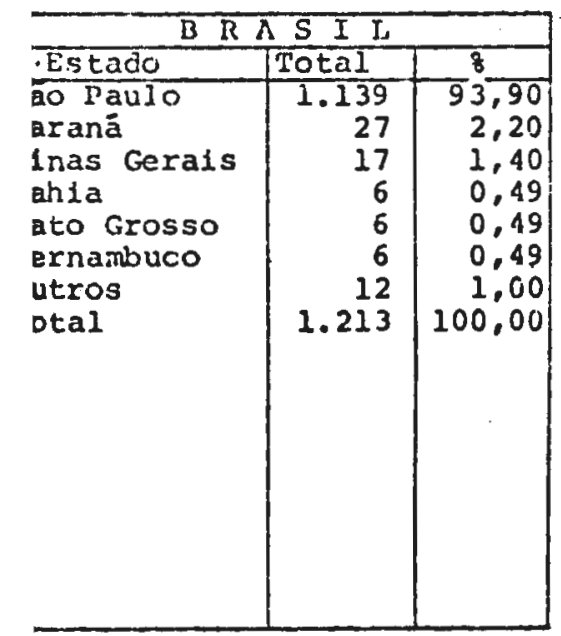

\begin{tabular}{|l|r|r|}
\hline \multicolumn{3}{|c|}{ Grande Sao Paulo } \\
\hline Cidade & Totai & \multicolumn{1}{|c|}{} \\
\hline Sá Paulo & 711 & 70,26 \\
Jandira & 126 & 12,45 \\
Osasco & 88 & 8,70 \\
Barueri & 22 & 2,17 \\
Itapevi & 16 & 1,58 \\
Mauã & 11 & 1,08 \\
Mairiporã & 10 & 0,99 \\
Carapicuiba & 7 & 0,69 \\
Outros & 21 & 2,08 \\
Total & 1.012 & 100,00 \\
& & \\
& & \\
& & \\
& & \\
& & \\
& & \\
& & \\
\end{tabular}

\begin{tabular}{|c|c|c|}
\hline \multicolumn{3}{|c|}{ Sao paulo } \\
\hline Bairro & Tetal & 8 \\
\hline Lapa & 172 & 24,19 \\
\hline Bom Retiro & 76 & 10,69 \\
\hline Barra Funda & 71 & 9,99 \\
\hline Sta. Efigênia & 40 & 5,62 \\
\hline Consolaçăo & 33 & 4.64 \\
\hline Sé & 31 & 4,36 \\
\hline PInheiros & 27 & $\begin{array}{l}3,00 \\
2.67\end{array}$ \\
\hline Butanta & 17 & 2,39 \\
\hline Sta. CecIlia & 14 & 1,97 \\
\hline Brās & II & 1,55 \\
\hline Perdizes & 10 & 1,41 \\
\hline $\begin{array}{l}\text { Sto.Amaro } \\
\text { V.Marlana }\end{array}$ & 8 & 1,12 \\
\hline Outros & 56 & 7,88 \\
\hline n/espec1f. & 118 & 16,60 \\
\hline Total & 711 & 100,00 \\
\hline
\end{tabular}

Fonte: Questionário Domiciliar 1973/74

- Estado de São Paulo, que se destaca quanto a rigem do fluxo migratório, participa também com 93,908 no que se refere ao local de trabalho anterior.

Em sua quase totalidade, os locais de serviços an teriores ficam na Grande São Paulo, ou seja, mil e doze individuos dos mil cento e trinta e nove encontrados pa ra o estado, o que leva a pensar que essa população já residia em Jandira e simplesmente mudou de emprego. 
Os aspectos relacionados com o nível de vida não se constituíram numa preocupação no iníclo da pesquisa. Nada obs tante, os primeiros dados conseguidos indicavam tratar-se de una população de ba1xo padrão econômico.

Elaborou-se,posteriormente, um questionärio comple mentar abordando apenas a alimentação. Essa amostra, porque feita "a posteriori", abrangeu apenas cento e setenta familias, consideradas suficientes, como indicação genérica.

Procurou-se determinar, em uma certa semana, a fre quêencia diāria do consumo de verduras, legumes, ovos, peixes , carne e leite nas refelções. Os dados obtidos foram transfor mados numa mesma unidade, relacionados com a. quantidade de pes soas, resultando o consumo diärio "per capita", por familia.

Por melo de consultas em bibliografia especializada, concluiu-se que o mínimo necessārio seria o consumo de 100 a $120 \mathrm{~g}$ de carne por pessoa. Como o dado obtido no questionário era por familia, foram feltas as necessärias conversōes, conse guindo-se gramas "per capita", por familia. Constatou-se, as sim, que apenas onze famillas $(6,488)$ consumiam o necessārio, trinta e seis familias $(21,188)$ consumian quantidades varią veis acima de $120 \mathrm{~g}$ por pessaa. Veriflcou-se mais que cento e dezesseis familias $(68,238)$ da amostra consumiam quantidades inferiores à necessāria. Destas oitenta e duas famílias $(48,238)$ consumiam menos de $70 \mathrm{~g}$ por pessoa.

- leite, mesmo sendo o más completo dos alimentos, nāo é ingerido por onze famílias da amostra. Excepcionalmethte, encotraram-se cinco familias que consumiam a quantidade máxima do ideal, ou seja, meio litro (500 g) por pessoa, por dia,eaté 
mais, correspondendo a 2,358 da amostra. 90,598 apresentam In dices inferiores ao necessárto. $E$ onze famflias $(6,478)$ não tomam le1te.

A despeito de toda campanha para consumo de peixe, este alimento praticamente não faz parte da dieta alimentar do fandirense. E consumido com certa freqüência por apenas qua renta e sels famillas, aparecendo raramente à mesa de cento e quatro familias. A falta de hábito de consumo do produto na alimentação do brasileịro, e seu elevado preço em comparação com o salário explicam o fato.

o ovo è a principal fonte de proteinas a que recor re a população. E consumido regularmente por cento e dezoito famililas $(69,418)$ e com menor freqüência por quarenta e oito . Apenas quatro familias não 0 utilizam.

Verduras e legumes são consumidos diariamente por 65,308 e 38,248 das familias, respectivamente. E, portanto , inexpressivo o número de famílias que não fazem uso de verdu ras ou legumes no cardápio.

Mesmo gostando desses produtos, hã familias que não têm condições de comprā-los sempre: sō raramente comem verdu ras $(32,358)$ e legumes $(45,88)$.

No tocante ao conjunto da allmentação, é bem nítida sua relação com os preços: os produtos mais baratos são consu midos diariamente por um número maior de familias, enquanto que os mais caros (carne, leite, peixe, etc) não o são.

Os dados collgidos a partix do questionário domi cillar $(73 / 74)$, referentes a utilldades domésticas, revelam que $\circ$ fogão a gắs não è um indicador de padrão de vida,uma vez 
que fol encōntrado em 98,978 das resldênclas pesquisadas; ape nas ofto familias, desprovidas de um mintmo de condição econō mica, não o possulam.

\section{- rádio e o televisor são encontrados nas diferen} tes camadas soćlais; liquidificador, enceradeirae máquina de lavar já aparecem em menor quantidace e não são vistos nas resıdências mais modestas. A mäquina de lavar, diretamente subordinada ao poder aquisitivo, só fol encontrada em 1,79 \& das residências, cujos ocupantes dispōem de melhores condi ̧̧ōes econômicas.

Como o fogão, os mōveis tambēm não servem como in dicadores de 'nivel de vida,pois vartavam muito os que se encon travam nas residências. Ainda que predominando os do tipo simples, as variações mascaravam os dados levantados. Apenas três familias, uma delas residente em un porão (utilizava até um fogare1ro), e duas outras, recém-chegadas, não possuram mó vel algum; as demais geralmente, tinham pelo menos, 0 indis pensāvel, isto è, cama. , mesa e banco. Em conversa com as familias, confirmou-se que, nas compras, a preocupação ma1or é o preço e não estado ou qualidade do móvel. Um outro fator que pesa muito è a forma de pagamento: nada menos que quatro centas e dezessels famílias,correspondendo a 53,408 da amos tra, compraram a prazo.

vivendo nestas condições, a população alnda não tem perspectivas de dias melhores, pols os interesses adminis trativos municipais e os dos habitantes não são os mesmos. A população está preocupada com a Inexistêncla de hospital,ăgua, serviço médico gratuito, telefone, enfim, todos os serviços essenciais. Enquanto isso a Prefeitura se propõe a desman char uma praça arborizada para cobri-la de concreto e trans formā-la em "estacionamento de carros", o que é estranhável. 
já que a cidade ainda não possul grande quantidade de veĺculos. Na verdade, apurou-se que apenas sessenta e cinco familias, ou seja $8,34 \%$, do total da amostra,possuiam automóvel. Adema1s, a derrubada de ārvores não se justificaria, mesmo que 0 problema de estacionamento realmente existisse.

Já fol consignado antes que posse de casa própria não significa, necessariamente, padrão de vida elevado, o que é reafirmado aqui pela alta densidade de hab/residência. A ana lise dos quadros XXX e XXXI e da Fig. XXXII o demonstram.

$$
\text { QUADRO - } X X X
$$

Residências - n8 de cômodos/n̊ de quartos

\begin{tabular}{|c|c|c|c|c|c|}
\hline \multicolumn{3}{|c|}{$C O M O D O S$} & \multicolumn{3}{|c|}{ QUARTOS } \\
\hline No & $\begin{array}{l}\text { total/residen } \\
\text { clas }\end{array}$ & 8 & N8 & $\begin{array}{l}\text { total/residen } \\
\text { cias }\end{array}$ & $\bar{z}$ \\
\hline 1 & 48 & 6,16 & 1 & 475 & 60,98 \\
\hline 2 & 159 & 20,41 & 2 & 227 & 29,14 \\
\hline 3 & 153 & 19,64 & 3 & 65 & 8,34 \\
\hline 4 & 187 & 24,01 & 4 & 10 & 1,28 \\
\hline 5 & 132 & 16,94 & 5 & 1 & 0,13 \\
\hline 6 & 60 & 7,70 & 6 & 1 & 0,13 \\
\hline 7 & 23 & 2,95 & total & 779 & 100,00 \\
\hline 8 & 6 & 0,77 & & & \\
\hline 9 & 6 & 0,77 & & & \\
\hline 10 & 2 & 0,26 & & & \\
\hline 11 & 1 & 0,13 & & & \\
\hline s/resp & 2 & 0,26 & & & \\
\hline total & 779 & 100,00 & & & \\
\hline
\end{tabular}

Fonte: Questionário Domiciliar 1973/74 
Residências - quarto/habitantes

\begin{tabular}{|c|c|c|c|c|c|c|c|c|c|c|c|}
\hline \multicolumn{2}{|c|}{1 quarto (2) } & \multicolumn{2}{|c|}{2 quartos (2) } & \multicolumn{2}{|c|}{3 guartos (2) } & \multicolumn{2}{|c|}{4 yuartos (2) } & \multicolumn{2}{|c|}{5 quartos (2) } & \multicolumn{2}{|c|}{6 quartos (2) } \\
\hline $\begin{array}{l}\text { no } \\
\text { res. }\end{array}$ & $\begin{array}{c}\text { r.? } \\
\text { hab. }\end{array}$ & $\begin{array}{l}\text { ni } \\
\text { res. }\end{array}$ & $\begin{array}{c}\text { n? } \\
\text { hab. }\end{array}$ & $\begin{array}{l}\text { n8 } \\
\text { res. }\end{array}$ & $\begin{array}{c}n ? \\
\text { hab }\end{array}$ & $\begin{array}{l}\text { no } \\
\text { res. }\end{array}$ & $\begin{array}{c}\text { no } \\
\text { hab. }\end{array}$ & $\begin{array}{l}\text { nes } \\
\text { res. }\end{array}$ & $\begin{array}{r}\text { no } \\
\text { hab }\end{array}$ & $\begin{array}{l}\text { n8 } \\
\text { yes. }\end{array}$ & $\begin{array}{c}\text { no } \\
\text { hab. }\end{array}$ \\
\hline 11 & 11 & 2 & 2 & - & - & - & $=$ & - & - & - & - \\
\hline 49 & 98 & 16 & 32 & 2 & 4 & 2 & 4 & - & - & - & - \\
\hline $\begin{array}{l}93 \\
99\end{array}$ & $\begin{array}{l}279 \\
396\end{array}$ & $\begin{array}{l}37 \\
43\end{array}$ & 111 & $\begin{array}{l}4 \\
9\end{array}$ & $\begin{array}{l}12 \\
36\end{array}$ & $\begin{array}{l}2 \\
2\end{array}$ & $\begin{array}{l}6 \\
8\end{array}$ & $\overline{-}$ & $\overline{-}$ & $\bar{z}$ & $=$ \\
\hline $\begin{array}{l}99 \\
71\end{array}$ & $\begin{array}{l}396 \\
255\end{array}$ & $\begin{array}{l}43 \\
25\end{array}$ & $\begin{array}{l}172 \\
125\end{array}$ & 13 & 65 & 1 & 5 & - & - & $=$ & - \\
\hline 62 & 372 & 41 & 246 & 11 & 66 & 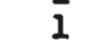 & 6 & 1 & 6 & - & - \\
\hline 33 & 231 & 16 & 112 & 10 & 70 & $=$ & - & - & - & 1 & 7 \\
\hline 26 & 208 & 22 & 176 & 5 & 40 & 1 & 8 & - & - & - & - \\
\hline 15 & 135 & 11 & 99 & 3 & 27 & - & - & - & - & - & - \\
\hline 7 & 70 & 6 & 60 & 2 & 20 & 1 & 10 & - & - & - & - \\
\hline 7 & 77 & 3 & 33 & 2 & 22 & - & - & - & - & - & - \\
\hline 1 & 12 & 5 & 60 & 2 & 24 & - & - & - & - & - & - \\
\hline 1 & 13 & - & - & 1 & 13 & - & - & - & - & - & - \\
\hline- & & - & $=$ & 1 & 14 & & & & & & \\
\hline 475 & 2.257 & 227 & 1.228 & 65 & 413 & 10 & 47 & 1 & 6 & $I$ & 7 \\
\hline
\end{tabular}

(1) repete-se para todas as residências e refere-se ao nüme ro de habitantes por residêncla, conforme o nümero de quartos.

(2) total de habitantes em cada tipo de residência.

Ex: há trinta e sete residências com três pessoas para dois quartos.

Fonte: Questionário Domiciliar 1973/74

Apurou-se que 57,028 da população da amostra moram em residênclas de apenas um quarto.

Os dados referentes ao número de divisões das casas configuram o predomín1o das de quatro cômodos; daI, poder-se-ia 


\section{RESIDÉNCIAS-QUARTO/HAB.}

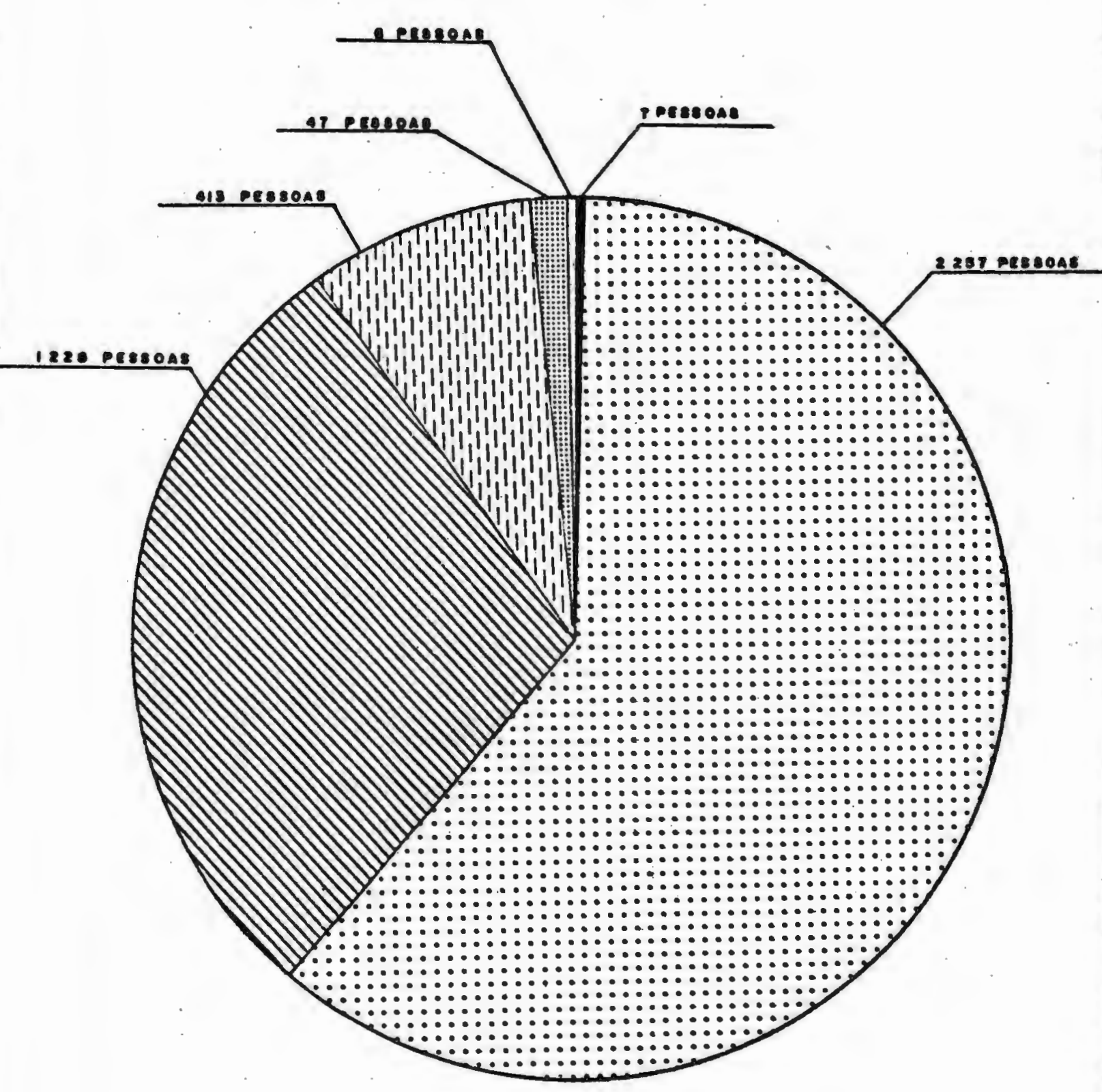

\section{LE GENDA}

$\cdots$

UM QUARTO

AIIV DOIS QUARTOS

WTITI TRES QUARTOS

III) QUATRO QUARTOS

\section{CINCO QUARTOS}

\section{thil sEIS QUARTOS}

Fontes ousstondinio DomiciLIAn is Ps/TA

oneamizado: P.4.0.canoien! 
pensar que sobressaisse o número de casas com pelo menos dois quartos, os outros dois cômodos sendo usados para sala e co zinha. A realidade, porém, não é essa, pois 60,958 das resí dências possuem apenas um quarto e são justamente as casas des te tipo que agregam um número maior de pessoas. Efetivamente, estes quatrocentos e setenta e cinco quartos abrigam 57,028 da população da amostra, com a média de 4,75 pessoas por quarto . $E$ parece não haver perspectivas de melhoria para essa popula ção, que possuindo baixos rendimentos, deve distribui-los de forma a conseguir sobreviver. Por exemplo, para alcançar me lhores salários na situação atual, uma pessoa deveria possuir, pelo menos, nivel médio de escolaridade. Entretanto, a reali dade mostra o contrário.

o certo é que a população, que se dispôs a morar distante do local de trabalho, motivada pela aquisição da ca sa própria, gasta boa parte do seu modesto salário com trans porte. Ao lado disso, gasta-se muito tempo no trajeto residên cia-trabalho. E esta população menos favorecida que geralmen te mais gasta com condução, proporcionalmente aos seus rendi mentos. 


\subsection{Fluxos: Trabalho-Residência}

A necessidade de mão-de-obra en Jandira ē reduzida , apesar do incentivo dado à industrialização. Este proces so, recente, ainda não gerou um mercado de ofertas de em pregos compatível com a procura.

Dessa forma, a população ativa continua a deslocar se diariamente para outras comunidades. Sendo a ferrovia - meio de transporte mais econômico, o deslocamento se faz, via de regra, para as áreas que se localizam ao longo do eixo da mesma. Isto pode ser observado no Quadro XXVI.

- fluxo diário é maior para são Paulo, onde trạ balham 59,94\% dos jandirenses economicamente ativos. Na Capital, esta força de trabalho se distribui por diversos bairros, destacando-se o da Lapa (vide Fig. XXXIII).A liās, a exemplo da Lapa,os bairros que mais se sobressaem são os ligados a Jandira por ferrovia

o inverso acontece com Pinheiros que, mesmo oferecen do terminal de linha de ônibus, que o liga a Jandira,não é muito procurado como local de trabalho. Pelo Quadro XXVI pode-se notar o número de habitantes de Jandira que nele desempenha suas atividades.

Uma outra parte da força ativa, ou seja 18,168, trạ balha no próprio município, is to é, nas poucas indústrias locals, no comércio e no setor de serviços, principalmente em imobiliārias e na agêncla do Banco Brasileiro de Descon tos. 
Para Osasco dirigem-se 10,108 dos trabalhadores, que all se dedicam, principalmente, às atividades ligadas a frigorifico e Indústria pesada.

Por f1m, para Barueri e Itapevi, desloca-se um peque no número, constituído quase que exclusivamente por pes soal empregado em construção, e domésticas.-

Atravēs de enquete, averigua-se que a ferrovia realmente o melo de transporte mals ut1lizado, posto que 61,478 dos deslocamentos são feltos por trem. As pessoas que exercem suas atividades no próprio município, em gran de parte não se ut1lizam de nenhum meio de transporte, re presentando 13,728 da população ativa. Alnda é representą tivo o ônibus, melo de transporte utilizado por cento e quarenta e uma pessoas, ou seja 9,778, sendo que, às ve zes, conforme o local de trabalho, o individuo precisa fazer uso do trem e do ônibus. Foram positivados noventa e sete ca sos deste tipo $(6,728)$. Poucas pessoas se utilizam de car ro próprio, alugado ou aa IIrma. Encontraram-se catorze pessoas que não preclsam se deslocar para trabalhar, uma vez que o trabalho é desenvolvido na própria residência . como, por exemplo, costureira, cabeleirelra e alfalate.

$$
\text { QUADRO - XXXII }
$$

Local de residência dos industriärlos de Jandira

\begin{tabular}{|c|c|c|c|c|c|c|c|c|c|c|c|c|}
\hline \multirow{2}{*}{$\begin{array}{l}\text { Empresas } \\
\text { Munlcip. }\end{array}$} & \multicolumn{2}{|c|}{ Metalürg. } & \multicolumn{2}{|c|}{ Frlgorif. } & \multicolumn{2}{|c|}{ Pedreira } & \multicolumn{2}{|c|}{ Premo } & \multicolumn{2}{|c|}{ Imprimé } & \multicolumn{2}{|c|}{ Blocos } \\
\hline & n8 & 8 & n? & $\varepsilon$ & n? & 8 & n8 & 8 & n8 & 8 & n? & 8 \\
\hline Jandira & 24 & 100,00 & 258 & 65,15 & 15 & 71,42 & 125 & 92,60 & 29 & 64.45 & 6 & 100,00 \\
\hline S.Paulo & & & & & 1 & 4,76 & & & 7 & 15,56 & & \\
\hline Carapicuiba & & & 10 & 2.53 & 1 & 4,76 & 3 & 2,22 & 1 & 2,23 & & \\
\hline paasco & & & 26 & 6.57 & & & & & 3 & 6,66 & & \\
\hline Itapev1 & & & 44 & 11,11 & & & 3 & 2,22 & 3 & 6.66 & & \\
\hline Barueri & & & 46 & 12,62 & 4 & 19,04 & 4 & 2,96 & 2 & 4,14 & & \\
\hline S. Rogue & & & 1 & 0,25 & & & & & & & & \\
\hline Santana de & & & & & & & & & & & & \\
\hline Parnalba & & & 2 & 0.25 & & & & & & & & \\
\hline Mailask & & & 2 & 0,50 & & & & & & & & \\
\hline
\end{tabular}

Fonte: Questionário para Atividades Econömicas - 1974 
o Quadro XXXII mostra o número de Individuos de outras cidades que trabalham em Jandira. Proporcionalmente, este nümero é bastante reduzı́do, comparado com 0 de pes soas que saem para trabalhar.

Já se registrou que os grandes centros são os procu rados pela população ativa de Jandira. Ju1llard - 1961, ao estabelecer relação entre a Europa industrializada e o Bra sil, quanto à organização do espaço periurbano, afırmou : "A aglomeração urbana termina abruptamente sobre um espaço periurbano, que apenas é transformado na medida em que a especulação fundiāria esterilizou de antemão a agricultura, visando a futura extensão das superfícles construídas (...). Assim, o fenōmeno da periferia limita-se a esta esteriliza ção anular, cercando una aglomeração que progride rapida mente, mas à mane1ra de uma mancha de öleo. Mesmo em tor no dos malores organismos urbanos, a organlzação do espaço não compreende a influência de uma parte das atividades so bre os centros satêlites e as migrações quotialanas de tra balho são unicamente centripetas".

\subsection{Fluxos: Comerciais}

A população utiliza-se dos serviços comerciais de outras cidades, porquanto o local fornece apenas gêneros básicos de consumo. Assim, procurou levantou-se onde são adquiridos os alimentos, vestuărios, móvels e eletrodomés ticos. (Vide fig. XXXIV).

Relativamente a alimentos, o municíplo dispõe de feI ra-Ilvre, supermercado, panificadora, açougue, o que dá pá ra prover as necessidades de quase toda a população. Na verdade, $85,11 \%$ das famílias se abastecem na própria cida de, o que não ocorre quanto aos demais 1 tens.

Os motivos que levam os jandirenses a procurarem 


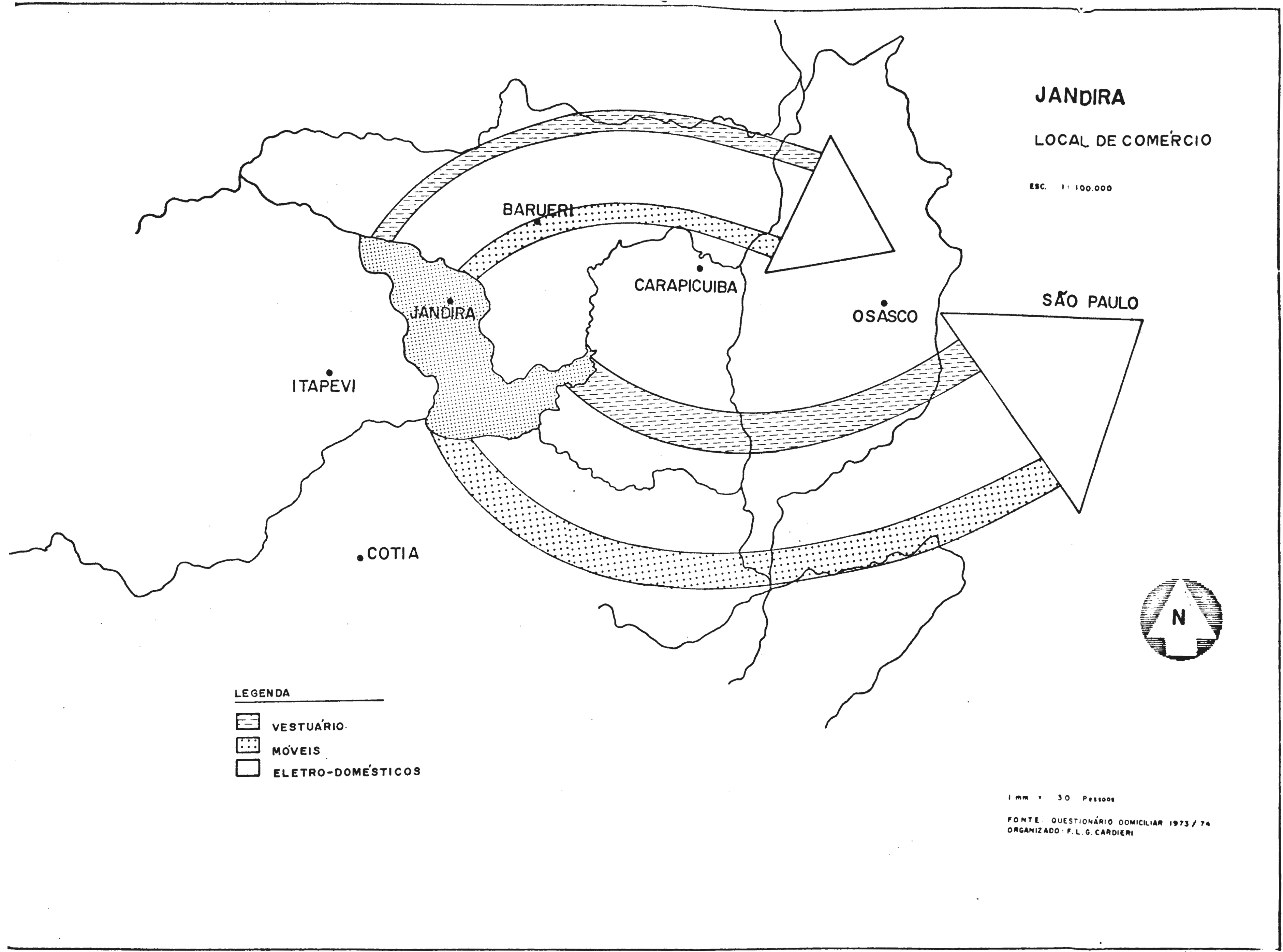


outros centros são os mais variados, mas destaca-se o pre fo das mercadorias. Pelo menos, esta é a afirmativa de 42,728 das familias que procuram outros lugares para suas compras. E é, igualmente, uma das justificativas de trin ta e nove familias $(35,458)$ que procuram são Paulo, princi palmente o bairro da Lapa, e de trinta e oito que se dir 1 gem para osasco, por ser este o centro comercial mais pró ximo. Novamente aqui a ferrovia tem importància, pois os lugares por ela servidos são os mais procurados.

Jandira deixa muito a desejar quanto ao comércio de vestuário. Fatores como preço, possibilidade de escolha, facilidade de crediário, proximidade do local de trabalho, levam os jandirenses a se voltarem para outros centros. Nes se caso, são Pauio, segundo 45,44\% dos moradores, é o me lhor local para compras. O municípic ne Osasco tem a pre ferência de cento e setenta e seis familias de Jandira , constituindo 22,608 do total; Jandira figura em terceiro lugar, já que apenas cento e quarenta e cinco famílias, de um total de setecentas e setenta e nove, adquirem o vestuâ rio na própria cidade.

Ao que se apurou, para compra de televisor, geladeira, rádio, fogão a gās, liquidificador, enceradeira,máquina de lavar e veículo, a cidade de São Paulo, en todos os casos, surge como a de maior preferēncia, sendo o comércio da Lapa - mais procurado. Em segúndo lugar coloca-se Osasco.

Jandira só entra na aquisição de rádios, representan do apenas 7,688 das compras; os demais municipios, quando aparecem, são pouco representativos.

Os móveis geralmente foram adquiridos antes dos pro prietários se fixarem na cidade, ao passo que os eletrodo mésticos o foram após a mudança para lā. Ainda assim, os que adquiriram móvets depois de estabelecidos en Jandira, deram preferēncia à cidade de são Paulo. Assim, duzentas 
e noventa e duas familias, constituindo 37,488 do total , compraram nessa cldade e cento e oltenta e quatro $(23,628)$, em 0sasco. Apenas oltenta e três familias $(10,65 \%)$ com praram móveis em Jandira.

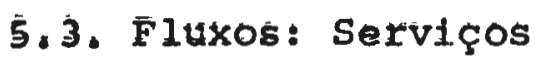

- panorama dos sérviços médicóodontológicos não é muito diferente. E recente a Instalação de un consultōrio dentário no local, com funcionamento regular. Entretanto, como não há atendimento êm todos os dias da semana e por uma sétie de outros motivos, como por exemplo o preço ele vado, o deslocamento de elientes para outras cidades ainda é frequente. Itapevi, Osasco e São Paulo são as mais pro curadas; em menor número procuram também Carapicuiba,Barue ri, e outros municípios da Grance são Paulo (observe-se a Fig. XXXV).

De outra párte, há ùm nümèro elevado de famílias que àinda não consultaram dentísta, depols que se Eixaram na ci dãde,

Os que vão ao dentista de Jandira fazem o trajeto de casa ao consultório a pé. Para as outras cidades o treméa principal forma de locomoção, pois 78,38\% das pessoas o utilizam normalmente. As razões alegadas para essa escoo tha foram: INPS(42), convênios, preço mais baixo, conhecí mento com dentista de fora, opinião de que dentistas de fora são melhores, ou ausência de centista em Jandira quan do houve necessidade.

Também são mais procurados para atendimento médico; a capital e osasco. Isto porque os doentes geralmente são encarninhados para atendimento através do INPS ou de convê nios. Apesar de um número significativo, 79,21\%, procurar este tipo de serviço em outras cidades, 20,798 da popula ção jă se volta para Jandira. A percentagem talvez não se 
ja maior por ser recente a fixação de um médico no local. as consultas serem particulares (pagas) e não haver aten dimento médico do INPS na cidade. A percentagem de famí lias que ainda não usaram mëdico ê de apenas 8,60\%.

Como no caso da procura de tratamento dentário, ape nas os que se locomovem no prōprio município o fazem a pé. Para procurar outras cidades o trem, também neste caso,é o melo de transporte mais mais solicitado $(72,18 \%)$, seguido pelo ônibus $(11,27 \%)$ e pela conjugação de ônibus e trem $(8,548)$. Percebe-se que a população ainda não dispõe, em número significativo, de carro próprio, pois em todas as situações sua referência como meio de transporte é reduzi da.

Jandira não conta com serviços hospitalares. Por is to, a população vê-se obrigada a procurăr outras cidades, entre as quais destacam-se São Paulo, Osasco e Carapicuiba. (Vide Fig.XXXV). Na verdade, não hã muita escolna, pois a população é atendida onde o INPS indicar.

Aqui tambēm o trem continua sendo o principal meio de transporte, seguido pelo ônibus e pela conjugação trem ônibus. o carro próprio apareceu como melo de transporte de trinta e três famílias pesquisadas. Tăxi e ambulância também são utilizados.

Só 22,348 das famílias não usam posto de saúde:

a quase totalidade da população procura o de Jandira(73,30:) . os poucos que vão a outras cidades, alegam que já tinham matrícula nesses locais, ou que quando precisaram ainda não havia posto em Jandira ou que preferem posto com me Ihores condições de atendimento. 
A malor parte da população adquire medicamentos nas farmäcias locais. Não obstante, às vezes, levados por di versos motivos, como por exemplo falta do medicamento dese jado, são obrigados a procurar farmácias em outro local.

\subsection{Fluxos:escolares e recreação}

Em 1974, 90,378 da população escolar, correspondendo a oitocentos e oitenta e cinco alunos, frequentavam o cur so de primeiro grau até quarta série lantigo curso primá rio). Como esse curso era oferecido pelo municipio, apenas 1,128 dos escolares utilizava-se de ónibus e 0,458 ia de carro próprio. Mencione-se que os estudantes residentes no Sagrado Coração, bairro de Jandira que tem uma estação ferroviária, utilizavam-se do trem para uma distância bas tante pequena (aproximadamente $2 \mathrm{~km}$ ), já que não havia e ainda não hã ônibus como opção; registraram-se dez ca sos deste tipo, correspondendo a 1,128 da população esco lar da amostragem.

Os alunos que frequentavam o curso colegial, 'atual segundo grau, deslocavam-se para Osasco, Barueri,Carapicui ba, Itapevi e São Paulo, caso em que, mais uma vez a fer rovia era o principal meio de transporte. Observe o Qua dro xxx.

Com referência aos cursos profissionalizantes é o município de Osasco que minora a deficiência de Jandira. 
Local da escola

\begin{tabular}{|c|c|c|c|c|c|c|c|c|c|c|c|c|c|c|}
\hline \multirow{3}{*}{ 1ciplo } & \multirow{3}{*}{ Total } & \multirow{3}{*}{1} & \multicolumn{12}{|c|}{ TRANSFOTE } \\
\hline & & & \multirow{2}{*}{ A } & \multirow{2}{*}{$\frac{p \vec{e}}{\bar{e}}$} & \multicolumn{2}{|c|}{ Onibus } & \multicolumn{2}{|c|}{ Trem } & \multicolumn{2}{|c|}{$\begin{array}{l}\text { Carro } \\
\text { Pröprio }\end{array}$} & \multicolumn{2}{|c|}{ Onibus } & \multicolumn{2}{|c|}{ G/Resposta } \\
\hline & & & & & No & 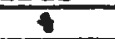 & N8 & 5 & กั\% & 8 & NO & $\frac{-2}{8}$ & $\frac{118}{118}$ & 8 \\
\hline IIra & 895 & 89,91 & 857 & 96,86 & 10 & 1,12 & 10 & 1,12 & 4 & 0,45 & - & - & 4 & 0.45 \\
\hline 100 & 37 & 3,77 & - & - & 10 & 27.03 & 18 & 48,65 & 4 & 10,81 & 1 & 2,70 & 4 & 10,81 \\
\hline leri & 14 & 1,43 & 7 & 50.00 & - & - & 6 & 42,86 & 1 & 7,14 & - & - & - & - \\
\hline Paulo & 13 & 1,33 & - & - & 5 & 38,46 & 6 & 46,16 & 1 & 7.69 & 1 & 7,69 & - & - \\
\hline plcuiba & 10 & 1,02 & - & - & 4 & 40,00 & 3 & 30,00 & 2 & 20,00 & 1 & 10,00 & - & - \\
\hline revi & 9 & 0,92 & 1 & 11,11 & 2 & 22,22 & 6 & 66,67 & - & - & - & - & - & - \\
\hline & 3 & 0,31 & - & - & - & - & - & - & 3: & 100,00 & - & - & - & - \\
\hline caba & 1 & 0.10 & - & - & - & - & 1 & 100,00 & - & & - & - & - & - \\
\hline jança & & & & & & & & & & & & & & \\
\hline Lista & 1 & 0,10 & - & - & - & - & - & - & 1 & 100,00 & - & - & - & - \\
\hline esposta & 11 & 1,11 & - & - & 2 & 18,18 & 8 & 72,73 & - & - & $-\cdot$ & - & 1 & 9.09 \\
\hline 11 & 984 & 100,00 & 865 & 87,93 & 33 & 3,35 & 58 & 5,89 & 16 & 1,62 & 3 & $0,3 n$ & 8 & 0,81 \\
\hline
\end{tabular}

Ponte: Questionārio Domiciliar 1973/74

Apenas doze alunos faziam curso superior. Para rea lizā-lo dirigiam-se principalmente para são Paulo, de ônibus ou trem, dependendo da lọcallzação da escola. Três alunos cursavam a faculdade em Itu, utilizando-se de car ro próprio. Houve um caso de deslocamento para Bragança Paulista e outro para Sorocaba, neste último, em geral de trem.

Brincar é a atividade principal das crianças até cinco anos. Com o propósito de levantar todas as ativida des recreativas e até que ponto elas são expressivas para a população sọ foramiinquiridas, na enquete sobre recrea ção, pessoas com cinco anos e mais.

Após enfrentar todas as dificuldades, residência-trạ balho, isto é, acordar muito cedo,viajar em ônibus outrens lotados, os jandirenses preferem descansar nos fins-de- se 
mana. Isto fica comprovado quando se verifica que 42,298 dos habitantes do muntcípio ficam em casa aos sảbados e do mingos. Teve-se oportunldade de positivar o fato, na oca sião da pesquisa, cujos questionārios foram aplicados aos sábados e domigos, ouando, multas vezes, a familia estava toda reunida na sala, assistindo a programas de televisão, geralmente de auditório. Ao lado disso, encontramos uma percentagem de 3,90z-correspondendo a cento e trinta e qua tro pessoas-que trabalham inclusive nos fins-de-semana.

Entre os que saem, muitos frequentam as igrejas, cons tituindo a maloria, 8,858da amostra. Destes, 5,658 procu ram a igreja de Itapevi.Detalhe curioso esse, uma vez que 0 municipio possul grande diversidade de cultos religiosos. visitar parentes é outro hábito da população. várias famí Ilas o fazem com frequência.

Para outras cidades, os deslocamentos se fazem em função de bailes, passeios, cinema, visto que o município não dispõe de infra-estrutura para recreação. Talvez isto seja a causa de numerosas pessoà ficarem em casa o dia to do, pols não dispondo de carro, como acontece com a malo ria da população, não é muito animador tomar ônibus ou trem para se divertir em outras cidades, tanto mais porque, em grande parte, os divertimentos são pagos.

As atividades podem ser vistas com detalhes no Qua dro XXXIV. 
QUADRO - XXXIV

Atividades de fins-de-semana

\begin{tabular}{|l|r|r|}
\hline Atividades & \multicolumn{1}{|c|}{ N8 } & \multicolumn{1}{c|}{8} \\
\hline Ficar em casa & 1.459 & 42,48 \\
Visitar parentes e amigos & 284 & 8,26 \\
Ir à igreja de Itapevi & 194 & 5,65 \\
Passear pela cidade & 169 & 4,92 \\
Trabalhar & 134 & 3,90 \\
Passear nas cidades vizinhas & 111 & 3,23 \\
Ir à missa & 110 & 3,20 \\
Outras & 488 & 14,21 \\
Sem especificação & 486 & 14,15 \\
Total & 3.435 & 100,00 \\
\hline
\end{tabular}

Fonte: Questionärio Domiciliar - 1974

Fez-se um levantanento junto a Fepasa, Viação Santa Clara e Himalaia Transporte Turismo Itda, com a finaliaa de de verificar o número de passageiros transportados.Ten tou-se o mesmo junto à empresa Benfica, que faz o atend1 mento municipal, mas esta, depois de várias solicitações e desculpas não satisfatórias para cada uma delas, negou-se a fornecer os dados.

No que se refere a transporte ferroviārio, è fācil apurar a quantidade de pessoas que deixam o municipio atravës da bilheteria. Todavia,acompra de passagem de subürbio, na Capital ou em outra localidade, não é contro lada quanto ao destino. o preço é único e em Jandira não existe nenhum tipo de controle que marque, o nümero de pessoas que estão chegando. Portanto, os dados forneci 
dos pela Fepasa quanto a passageiros embarcados só deve rlam omitir as pessoas que comprassem passagem ro próprio txen. Notou-se que existe também o problema da falta de pessoal para trabalhar na estação, dai os dajos não serem totalmente confiāveis. Consequentemente, foram considera dos apenas os dados de embarque de passageiros tanto para trem como para ônibus.

\section{QUADRO - XXXV}

Transporte Coletivo - Número de Passageiros

\begin{tabular}{|c|c|c|c|c|}
\hline \multirow{2}{*}{ Ano } & \multicolumn{2}{|c|}{$T r e m$} & \multicolumn{2}{|c|}{$O n i b u s$} \\
\hline & Total & Tedia Diária & Total & Méaia Diaria \\
\hline 1964 & 312.752 & 668,75 & & \\
\hline 1965 & 266.503 & 740,28 & & \\
\hline 1966 & 277.263 & 771,18 & & \\
\hline 1967 & 310.043 & 861,23 & & \\
\hline 1968 & 311.957 & 866,54 & & \\
\hline 1969 & 471.985 & $1.311,06$ & & \\
\hline 1970 & 703.796 & $1.954,98$ & & \\
\hline 1971 & 752.160 & $2.089,33$ & & \\
\hline 1972 & 963.776 & $2.677,15$ & & \\
\hline 1973 & 1.061 .438 & $2.948,43$ & 87.171 & 242,11 \\
\hline 1974 & 1.004 .109 & $2.789,19$ & 257.506 & 715,29 \\
\hline 1975 & 880.263 & $2.445,17$ & 277.192 & 769,97 \\
\hline 1976 & 929.286 & $2.581,35$ & 340.310 & 945,30 \\
\hline 1977 & 600.990 & $1.669,41$ & 275.886 & 766,35 \\
\hline 1978 & 263.648 & 732,35 & 412.732 & $1.146,47$ \\
\hline
\end{tabular}

Fonte: Relatórios da Fepasa

Vịação Santa Clara e Himalaia Transporte Turismo Ltda.

o Quadro XXXV indica que o transporte ferroviário a presentou crescimento contínuo até 1973. Nesse ano, a cí dade passou a contar com sistema rodoviário para transpor te coletivo. Como a população pode optar entre um siste na e outro, a partir de então a progressão passou a ser 
crescente para os passageiros de ônibus e decrescente para os de trem. Mesmo assim, deve-se considerar que o dado de transporte ferroviário para 1978 não deve estar correto pois o relatório da Fepasa cita falta de pessoal trabalhan do na estação de Sagrado Coração. Acredita-se que o mesmo deve ter ocorrido na de Jandira.

Na pesquisa domiciliar 1973/74, verificou-se a pre ferência pelo trem como meio de transporte, e os dados obtidos a confirmam, pois foram esses anos que apresenta ram as maiores médias diárias, respectivamente $2.948,43$ e 2.789,19 embarques diārios. Considerando-se que o muni cípio possuia dezesseis mil e trinta e seis habitantes em 1973, para cada cem pessoas, registru-se 18,37 como média diária. Langenbuch-1971, tratando do assunto apresenta pa ra o período 1960/1965 uma média diária de seiscentas e sessenta e uma pessoas e média diāria por cem moradores locais de 32,2 . Segundo ele, os "eixos de urbanização em colar" (43) apresentaram os indices mais altos.

A economia de tempo e de dinheiro, associada ao $\underline{i}$ tinerário do trem, que passa por bairros a que a popula ção é praticamente obrigada a recorrer para sanar as defí clências de infra-estrutura da cidade, faz com queo subūr bio seja o principal meio de transporte.

Tércia Correia Cavalcante - 1979, analisando o pa pel desempenhado pelo trem de subúrbio no vizinho municí pio de Barueri, colocou muito bem as razões de ser o mes mo o principal veículo de locomoção. Preocupou-se muito com as vantagens em relação ao tempo de percurso, e com

(43) Langenbuch em sua obra Estruturação da Grande São Pau lo - p. 303 cita Jandira como exemplo de "eixo de urbani zação em colar ". Na página 152 encontra-se: "A polarizā ção em torno das estações provocava o desdobramento dà ărea urbanizada (na faixa suburbana) na forma de colar". 
a tarifa e o serviço de passe mensal com abatimento de 258 sobre a tarifa normal, para particulares, e 758 para famí lias de ferroviārics. Enfatizou também o trajeto diferen te do trem e do ônibus: enquanto em todo o seu trajeto o trem atinge bairros de expressão econômica, no caso dos ônibus apenas os bairros terminais são economicamente ex pressivos. Todos esses aspectos são encontrados neste cen tro urbano, que, tambēm como Barueri, ainda tem as caracte risticas de um núcleo dormitório. 
o crescimento da taxa de urbanização da população do municlpio deveu-se, em parte, a medidas administrativas. A Pre feitura desejando, provavelmente, maior arrecadação de impostos, definiu como perimetro urbano o limite municipal. Esta, a ra zão pela qual o municipio não contava mais com população rural no Censo de 1970 (FIBGE). As caracteristicas do município, no entanto, não se alteraram significativamente, uma vez que a ati vidade agrícola nunca teve grande importância na economia local.

o crescimento populacional está relacionado com a lo calização do município em periferia de metrópole servida por metos de circulação.

Esse crescimento foi devido, principalmente, à imi gração. Dada a taxa elevada de proprietārios de residência, con clui-se que a cidade foi procurada por possibilitar a aquisição de terrenos e posterior construção de moradia mesmo com modesto orçamento.

A ārea em estudo, encontrando-se no início do proces so de industrialização, ainda se apresenta como cldade- dormitó rio, isto é, ainda não oferece condições satisfatōrias de infra estrutura geradora de empregos a sua população. A parcela eco nomicamente ativa desta, em geral constituída por operários , ainda se vê obrigada a percorrer grandes distâncias em busca do seu baixo salário.

A instalação de indústrias ainda não modificou as caracteristicas gerais do municipio. Sabe-se que as mesmas po dem levar à implantação de serviços, comércio, recreação para os habitantes, mas até 1979 a cidade não apresenta mudanças siq nificativas. 
As deficiências referentes a tais aspectos ainda

são supridas pelos municípios vizinhos, principalmente são paun 10 e Osasco. Jandira, até o momento, continua a oferecer à Grande são Paulo sua reserva de espaço e mão de obra, além de sua produção industrial.

Efetivamente, nesta ordem de considerações e sem em bargo dos bucólicos propósitos de pelo menos alguns de seus pio neiros, o município de Jandira não pode ser visto senão como um dos muitos nucléolos que surgiram em torno da cidade de são Paulo, e se expandiram por efelto de uma atração - quem sabe newtoniana. A rigor, como as demais cldades-satélites da me galópole bandeirante, Jandira cresceu em função do centro maior, pelo qual fol e está sendo absorvida, num processo que lembra a fagocitose. De tal modo que, hoje, não serla absurda a asserção de que o pequeno núcleo já se incorporou ao maior, engolfada pe lo seu insaciável gigantismo. Jandira é, 1rxeversivelmente , parte Inseparāvel do gigante denominado - A Grande São Paulo. 


\section{BIBLIOGRAFIA}

3'SABER, Aziz Nacib - Geomorfologia do sitio urbano de são Paulo. São Paulo, 1957. (Tese de Doutoramento-F.F.C.I.H. USP. Departamento de Geografia).

- o sitio urbano de sāo Paulo. In: AZEVEDo, Aroldo de A clade de São Paulo: estudos de geografia urbana. São Paulo Ed. Nacional, 1958. V.I, cap. VI.

LEGRic, Marcos - Aspectos do fato urbano no Brasil-Análise quantitativa pelo método cartografico. Presidente Prudente, F.F.C.I. Presidente Prudente, 1970.

LMEIDA, Fernando Flävio M. - o planalto paulistano. In: AzEVEDo Aroldo de - A cidade de São Paulo: estudos de geografia urbana. São Paulo, Ed. Nacional, 1958. v.I, Cap. IV.

- Fundamentos geológicos do relêvo paulista. são Paulo,

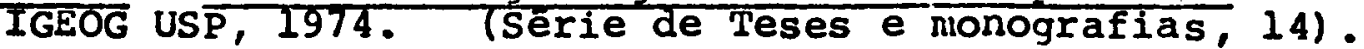

NDRADE E SILVA, Raul de - são Paulo nos tempos coloniais. In: AZEVEDO, Aroldo de - A cidade de são Paulo: estudos de geografia uroana. - são Paulo, Ed. Nacional, 1958. v.II, cap. I.

RAUJO FILHO, Josẽ Ribeiro de - A população paulistana. In: AZEVEDO, Aroldo de - A cidade de São Paulo: estudos de geografia urbana. São Paulo, Ed. Nacional, 1958. V.II, cap. IV.

RQUIVO do Estado de São Paulo - Sesmarias. São Paulo, tipographla Piratininga, 1921. V.I - VI.

ZEVEDO, Aroldo de - Os suburbios de são Paulo e suas funçōes. Boletim da A.G.B., São Paulo, 4 (4), 1944.

- Vilas e cidades do Brasil colonial: ensaio de gengrafia uroana - retrospectiva. Sao Paulo, 1957. (Anais da A.G.B.).

- Embriōes de cidades brasileiras. Boletim Paulista de Geografia, São Paulo, mar. 1957.

- São Paulo, cidade trimilionåria. In: de de São Paulo: estudo de geografia urbana. V.I. Cap. I.

- São Paulo metrópole do planalto. In: Congresso Internacional de Geografia, 188, Rio de Janeiro, 1960.

- Geografia das metrópoles brasileiras: os estudos existentes seus caracteres e sua orientaçao. Sao Paulo, A.G.B., 1960. V.12. (Anals da A.G.B.). 
- São paulo de vila quinhentista a metrópole regional. Boletim Paulista de Geografia, Säo Paulo, (39), 1961.

BASTIE, Jean - La croissance de la Banlieu Paristenne. Paris, Presses Universitaires de France, 1964.

BEAUJEU - GARNIER, Jacqueline \& Chabot, Georges - Traité de geogra phie urbaine. Paris, A. Colin, 1963.

- Geografia da população. São Paulo, EDUSP, 1971.

BERNARDES, IÍgia Cavalcanti - Elementos para o estudo geogrä́fico das cidades: exemplos brasileiros. Boletim Geográfico, Rio de Janeiro, $18(154), 1960$.

BERRY, Brian \& BAKER, Alan - Amostragem geogrăfica. Textos Bäsicos, Rio de Janeiro, Instituto Panamericano de Geografia e HisEoria (3) 1969.

BRASIL, Lels, decretos, etc - Código tributārio nacional. Brastlia. s.d.

BRUNo, Ernani Silva - Esboço de História e povamento em são Paulo. In: São Paulo: terra e povo. São Paulo, Ed. Globo, 1967 .

CaMARGo, Cândido procóplo Ferrelra de et Alil - São Paulo 1978 crescimento e pobreza. São Paulo, Loyola, 1976.

CARLOS, Maria Rodrigues - Santana de Parnaiba son role dans la zone suburbaine de são Paúlo. (Brêsil). Paris, 1973. (Tese de mestradol.

CAVALCANTE, Têrcia Correia - Barueri e sua participação no conjunto da faixa periférica da metropole paulistana. Sao Paulo, 1979. (Dissertaçao de mestrado. F.F.L.C.H. USP. Departamento de Geografia).

CESAR, Heldio Xavier Lenz - Solucões gräficas na cartografia de fe nômenos quantitativos. Separata da Revista Brasileira de Geografia, 20 (1), jan./mar. 1956.

CONTADORIA Geral dos Transportes - Guia geral das estradas de ferro e empresas de transportes com elas articuladas- G I.

Costa, Emilia Vlotti - Cotia e Itapecerica da serra, subúrbios agrícolas. In: AZEvEDo, Aroldo de - A cidade de são Paulo: es tudo de geografia urbana. São Paulo, 1958. v.IV, cap. III.

DAVIES, Wayne K. D. - Teoria, ciência e geografia. Boletim cario ca de geografia: metodologia em geografia, Rio de Janeiro (I), 1976.

DE BIASI, Mário - cartas de declividade: confecções e utilização. Geomorfologia, são Paulo (21), 1.970. 
- Madidas graficas de uma carta topogräfica.

de clênclas da terra, são Paulo, (35), 1973.

DEFFONTAINEs, Pierre - como se constituiu nobrasil a rede das cida des. Boletim Geogrăfico, Rio de Janeiro, 2 (14/15), maio 1944

DEMANGEON, Albert - Problèmes de geographie humaine . Paris, A. Co Iin, 1947.

DERRUAU, Max - Precis de geographie humaine. Paris, A. Colin, 1961.

DOLLFUS, Olivier - O Espaço geogrăfico. São Paulo, Difusāo Europela do LIvro, 1972. (Coleçao, Saber Atual).

E.F.S. - Relatório. São Paulo, consultoria juridica, 1930.

FREITAS, Affonso A. de - Geografia do estado de são Paulo. São

Paulo, Escolas profissionals Salestanas, 1906.

IBGE - Recenseamentos gera1s - censos gerais: 1950,60 e 70 . Rio de Jane1ro, s.d.

GASPAR, Francisco Antonio - Histōrico do iniclo, fundação, constru cão e inauguração da E.F.S. $(1870-1875)$. Săo Paúlo, Eugenio cupolo, 1930.

GEIGER, Pedro Pinchas - Evolução da rede urbana brasileira. Rio de Janeiro, Centro de Pesquisas Educacionals, 1963. TColeção Brasil Urbano).

GEORGE, Pierre - Compêndio de geografia urbana. Trad. de Jorge Garzolini. Barcelona, Ed. Ariel, 1964.

- Critica geográfica do desenvolvimento urbano. In: A geografia ativa. São Paulo, Difusāo Européia do

Livro, I968. cap. IV.

- Geografia da população. São Paulo, Difusão Europēia do LIvro, 197I. (Coleçao Sajer Atual).

GIMENES, Miguel Benites - Os frigorificos da Grande são Paulo e arredores: estudo geogrăfico. Sao Paulo, 1978. (Dissertação de Mestrado. F.F.L.C.H.-USP. Departamento de Geográfia).

HARTSHORNE, Richard - Questão sobre a natureza da geografia. Tex tos Básicos, Rio de Janeiro, Instituto Panamericano de GeograIia e Historia, (4), 1969.

JANDIRA. Prefeltura Municipal - Relatōrio Administração osvaldo Sammartino 1965/1968. Jandira, s.d.

JUILLARD, Etienne - Europa industrial e Brasil dois tipos de orga nizaçắo do espaço. Boletim Baiano de Geografia, (4), 1961. 
LA BLACHE, Vidal de - Principios de geografla humana. IIsboa, Cosmos, 1954 .

LANGENBUCH, Juergen Richard - Estruturação da Grande São Paulo: es tudo de geografia urbana. Rio de Janeiro, IBGE, 1971. (3ibloteca Geográfica Brasileira, 26).

LE BOURLEGAT, Cleonice Alexandre - A cidade de Salesōpolis e suas relaçöes com a metröpole. São paulo, 1978. TDissertaçao de Mestrado F.F.C.I.L. da USP)

LEMOS, Amália Ines Geraiges de - Cotia e sua participação no conjunto da faixa periférica da metrópole paulistana. Săo paulo, 1972. (Dissertaçao de Mestrado. F.F.C.H.L da USP).

LERNER, Jalme - o desenvolvimento urbano no Brasil. Revista Brasileira de Planejamento, I.B.P. Porto Alegre, $(8): j$ jin. 1978.

LIBAULT, André - Geocartografia. São Paulo, EDUSP, 1975. V.I. (Biblioteca universitária, 6 ).

MARCILIo, Maria Luiza - A cidade de São Paulo: povoamento e popula ção - 1750-1850: com base nos registros paroguiais e nos recenseamentos antigos. São Paulo, EDUSP/Pioneira, 1974.

MARques, Manoel Eufrásto de - Apontamentos histōricos, geogrä́ficos estatisticos e noticiosos da provincia de Săo paulo. Sao paulo Martins, 1953. t.II.

MATOS, Adilson Nogueira - A evolução ferroviária de são Paulo. Rio de Janeiro, C.N.G., T940. V.IV (Anais do IX Congresso Bra sileiro de Geografia).

- são paulo no séc. XIX. In: AZEvEdo, Aroldo de - A ciaade de são paulo: estudos de geografia urbana. São paulo, Ed. Nacional, 1958. v.II, Cap. II.

MONBEIG, Pierre - Aspectos geográficos do crescimento da cidade de são Paulo. Boletim Paulista de Geografia, são Paulo, A.G.B. (16), 1954 .

MonteIro, Carlos Augusto de Figueiredo - A dinâmica climática e as chuvas no estado de säo paulo. São paulo, EDUSP, 1973.

MULLER, Dantel Pedro - Ensaio d'um quadro estatistico da província de são Paulo em 1836. O Estado de São Paulo. 1923.

MULLER, Nice Lecocq - Contribuição ao estudo do fato urbano e da organização do espaço no Vale do Paraiba, estado de sao paulo. Sao Paulo, 1962. (Tese F.F.L.C.H.USP. Departanento de Geografia).

NAKASHIMA, Myriam da Silveira Reis - Estudo topomorfológico e de formaçōes superficiais na ärea de Barueri earredores. Sao paulo, 1979 (Dissertaçao de Mestrado.F.F.L.C.H.-USP. Depar tamento de Geografia). 
OLIVEIRA, Maria Niedja Leite - Embu e sua participação no conjunto da faixa periférica da metropole paulistana. Sao Paulo, 1972. (Dissertaçao de Mestrado. F.F.L.C.H. da USP).

PENTEADO, Antonio Rocha - Contribuição ao estudo da região suburbana de são Paulo. são Paulo, A.G.B., 1957. v.IX, t.I

TAnals da A.G.B.T.

- A ãrea suburbana de São Paulo e sua caracterização.

Sao Paulo, A.G.B., 1960. v.XII (Anais da A.G.B.)

- PETrone, Pasquale - São Caetano do sul e Osasco, sübúrbios industriais. In: AZEVEDo, Aroldo de - A cidade de são Paulo: estudos de geografia urbana. São Paulo, Ed. Nacional, 1958. Vol. IV, cap. II.

PETRONE, Pasquale - São Paulo no século XX. In: AZEvEDo, Aroldo de - A cidade de São Paulo: estudos de geografia urbana. São Paulo, Ed. Nacional, 1958. v.II, cap. III.

- Notas sobre o fenômeno urbano no Brasil. São Paulo, A.G.B., 1960. V.XII. (Anais da A.G.B.)

- Pinheiros: aspectos geográficos de un bairro paulistano. Sao Paulo, EDUSP, 1963

- Os aldeamentos paulistas e sua função na valorização da regiảo paulistana: estudo de geografia historica. São paulo, 1964. (T'ese ae Livre-Doceñcia. F.F.C.L.-USP).

PLANO DIRETOR de Jandira: triênio 1967-1969. s.l.p., s.d.

PONTUSCHKA, Nídia Nacib - Suzano e o impacto da industrializacão. São Paulo, 1979. (Dissertaçao de Mestrado. F.F.C.H.L.-USP.

Departamento de Geografia).

RANGEL, Ignácio Mourão - Questão agrãria e agricultura. São Paulc 1978.

REGIONAL: sem atençōes. Folha de são Paulo. São Paulo, 12 maio 1979. p.21.

ROCHEFORT, Michel - Método de estudo das redes urbanas. Boletim Geográfico, São Paulo, 19 (160), 1961.

- Um método de pesquisa das funçöes características de uma metrópole regional. Boletim Geoģráfico, São Paulo, 26 (198), 1967.

- - I'armature urbaine et le reseau urbain, Notions et pro blemes methodologiques d'analyse. Revista Geográfica, Rio de Janeiro, 35 (63), 1965.

SAINT-HILAIRE, Auguste de - Viagem à provincia de são paulo. São Paulo, Martins/EDUSP, 1972 . 
SĀO PAULO. Secretaria de Econonia e Planejamento. Grupo Executivo da Grande são paulo. GEGRAN - Estudo da sub-região noroeste da Grande são Paulo: relatório fiñal. Sao Paulo, 1969.

- PMDI- Plano Metropolitano de Desenvolvimento Integrado da Grande Sao Paulo. Sao Pallo; 1970.

- Diagnóstico da la. região Administratıva: Grande São

Paulo. Sao Paulo, 1973.

SÃo PAULO. Secretaria dos Negöcios Metropolitanos. Sistema de planejamento e Administrativo- SPAM - Programa de atendimento aos municipios em assuntos de interesse metropolitano: Diagnóstico Municipal - Janaira 77. Sao Paulo, 1977.

SÃo PAULO. Secretaria dos Negócios Metropolitanos. Empresa Metropo litana de Planejamento da Grande São Paulo S.A.- EMPLASA - Sumã rio de Dados 78. São Paulo, 1978.

SHAEFER, Fred. K - o excepcionalismo na geografia: um estudo metodológico. Boletim Carioca de Geografia: metodológia em geogra fla, Rio de Janeiro, (1).

SINGER, Paul, coord. - Recursos humanos na grande são paulo. São Paulo, 1971. V.I e II.

- Economia politica da urbanização. São paulo, Brasi-

Iiense, 1976.

SOCIEDADE para a Anälise Grăfica e Mecanogräfica aplicada aos Complexos Sociais, São Paulo - Relatório SAGMACS: plantas de estru turação escalas: 1:20000 e 1:50000. Sao Paulo, 1957. Relató Fio $1 B, 20$ plts.

- Relatōrio sobre são paulo. São Paulo, 1957.

A SOLUÇÃo para esta cidade. Diário Popular. são Paulo, 19 dez. 1978. p. 5

TRICART, Jean - Contribuição ao estudo das estruturas urbanas. Boletim Geogrāfico, Rio de Janeiro, 14 (135), 1956

- L'habitat urbaine. 3a. ed. Paris, Folurier Constans s.a.u. fasc. II.

UNESCO - International, classification and mapping of vegetation. Par1s, 1973. (Serie Ecology and conservation, 6).

VANZOLINI, P.E. \& PAPAVERO, N. - Indice dos topônimos contidos ná carta do Brasil 1:1000000 do IBGE. São Paulo, FAPESP, 1968.

WILHEIM, Jorge - São Paulo metröpole 65. São Paulo, Difusão Euro péia do Livro, 1965. 
- Urbanismo no subdesenvolvimento. São Paulo, Ed. Saga

:ALUAR, Augusto Emilio - Peregrinação pela província de são Paulo: 1860-6I. São Paulo, Itatiaia, EDUSP, 1975. Coleçá Reconquista do Brasil, 23i. 
A digitalização deste documento foi possível graças ao investimento do Programa de Pós-graduação em Geografia Humana (PPGH-FFLCH-USP) e realizada com recursos da Coordenação de Aperfeiçoamento de Pessoal de Nível Superior - Brasil (CAPES) - Código de Financiamento 001. Essa ação integra as atividades de comemoração dos 50 anos do PPGH no ano de 2021. Para mais informações sobre o PPGH e sua história, visite a página do programa: http://ppgh.fflch.usp.br/.

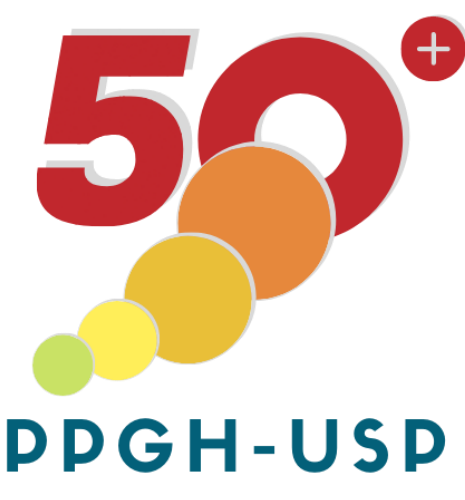

$1971-2021$ 